In cooperation with the Milwaukee Metropolitan Sewerage District

Water-Quality Characteristics for Selected Sites within the Milwaukee Metropolitan Sewerage District Planning Area, Wisconsin,February 2004-September 2005

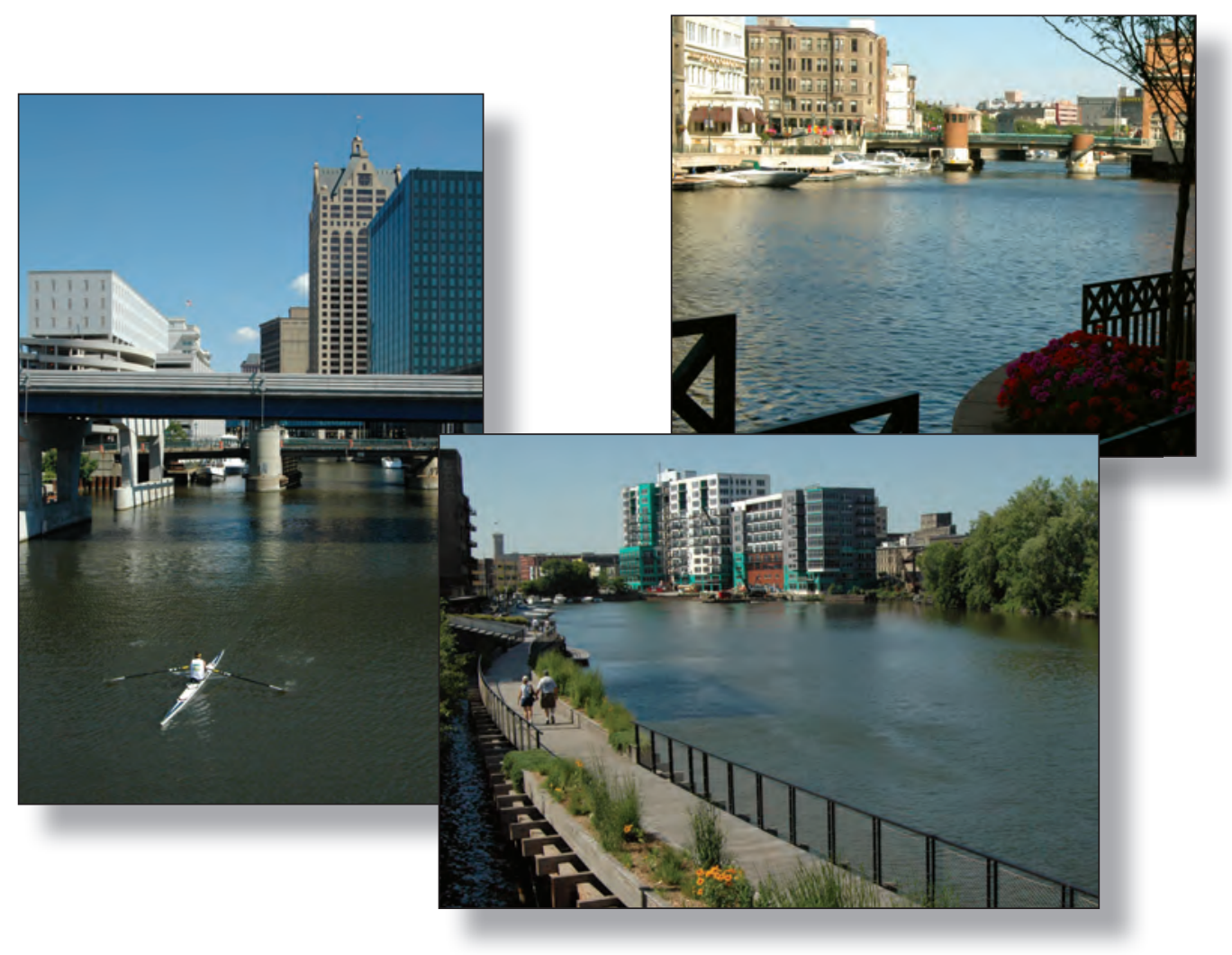

Scientific Investigations Report 2007-5084 



\section{Water-Quality Characteristics for Selected Sites within the Milwaukee Metropolitan Sewerage District Planning Area, Wisconsin, February 2004-September 2005}

By Judith C. Thomas, Michelle A. Lutz, Jennifer L. Bruce, David J. Graczyk, Kevin D. Richards, David P. Krabbenhoft, Stephen M. Westenbroek, Barbara C. Scudder, Daniel J. Sullivan, and Amanda H. Bell

In cooperation with the Milwaukee Metropolitan Sewerage District

Scientific Investigations Report 2007-5084 


\section{U.S. Department of the Interior DIRK KEMPTHORNE, Secretary}

\section{U.S. Geological Survey \\ Mark D. Myers, Director}

\section{U.S. Geological Survey, Reston, Virginia: 2007}

For product and ordering information:

World Wide Web: http://www.usgs.gov/pubprod

Telephone: 1-888-ASK-USGS

For more information on the USGS — the Federal source for science about the Earth, its natural and living resources, natural hazards, and the environment:

World Wide Web: http://www.usgs.gov

Telephone: 1-888-ASK-USGS

Any use of trade, product, or firm names is for descriptive purposes only and does not imply endorsement by the U.S. Government.

Although this report is in the public domain, permission must be secured from the individual copyright owners to reproduce any copyrighted materials contained within this report.

Suggested citation:

Thomas, J.C., Lutz, M.A., and others, 2007, Water-quality characteristics for selected sites within the Milwaukee Metropolitan Sewerage District planning area, Wisconsin, February 2004-September 2005:

U.S. Geological Survey Scientific Investigations Report 2007-5084, 187 p. 


\section{Contents}

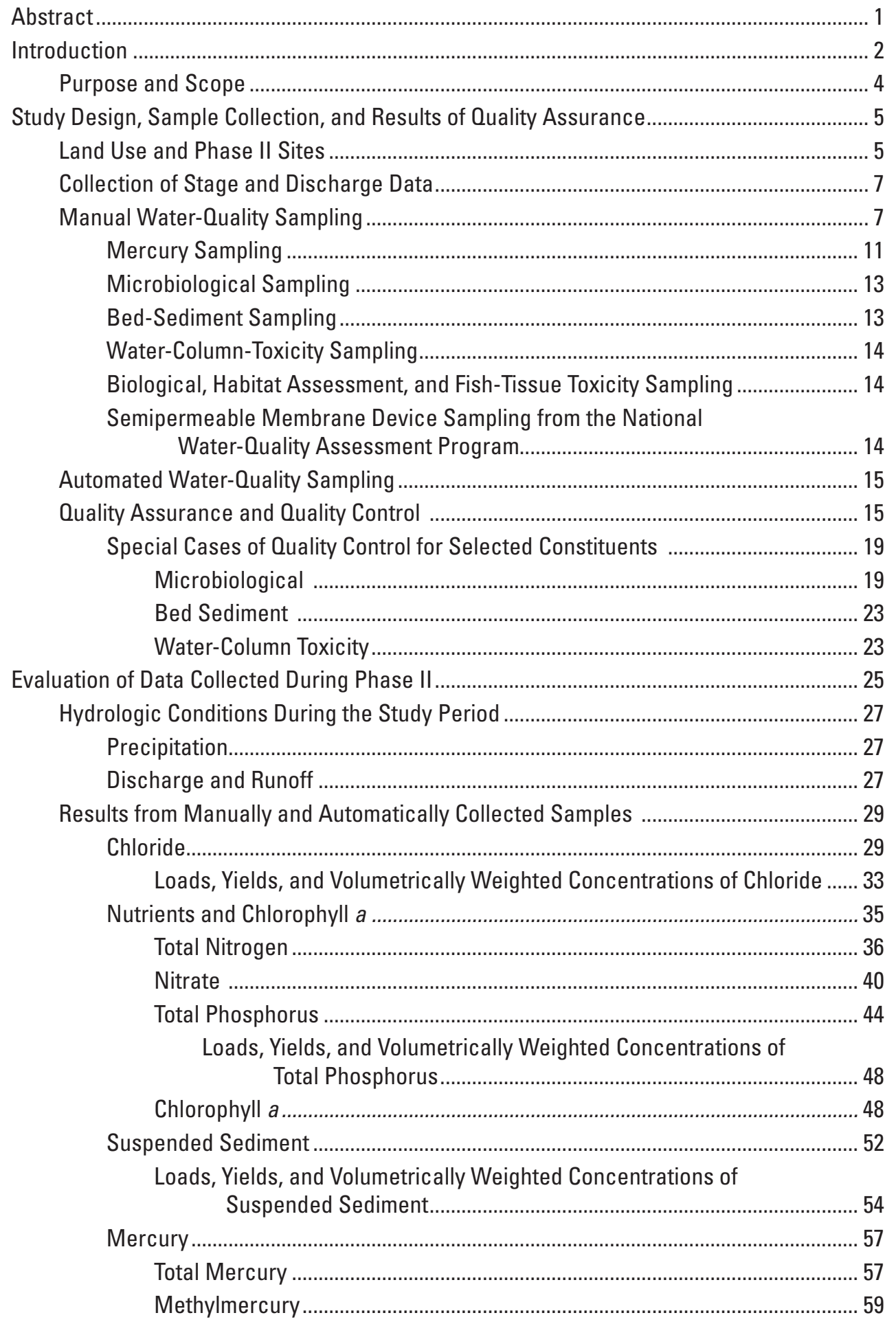




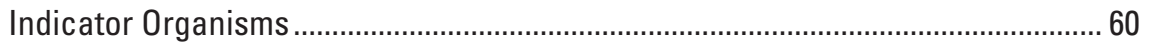

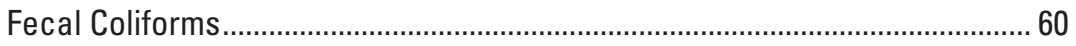

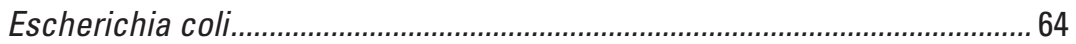

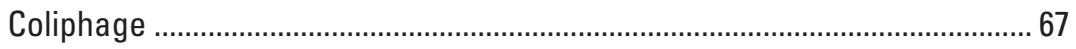

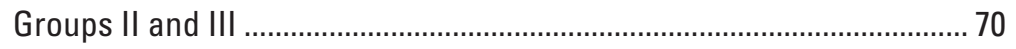

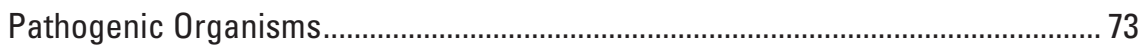

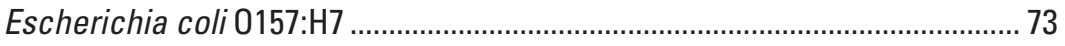

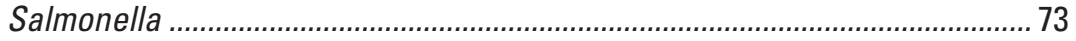

Detection Frequencies................................................................... 74

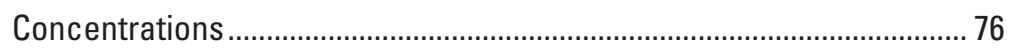

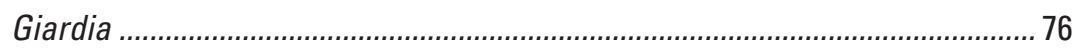

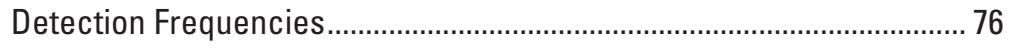

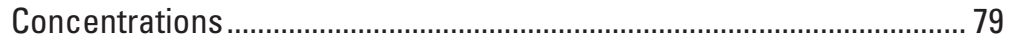

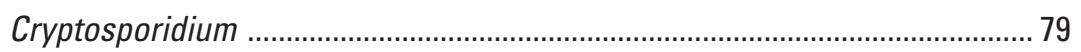

Detection Frequencies.......................................................................... 80

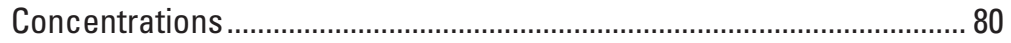

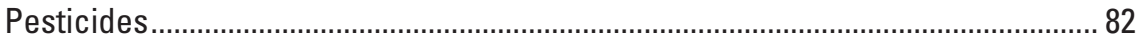

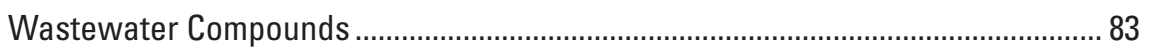

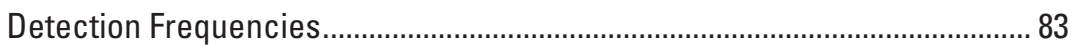

Response to Flow and Seasonality .............................................................. 94

Dominant Constituents in Wastewater Compound Classes ......................... 100

Endocrine-Disrupting Chemicals ................................................................ 102

Semipermeable Membrane Devices and Wastewater Compounds...................... 104

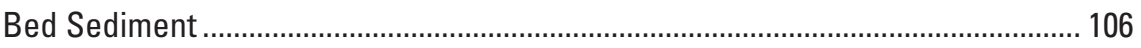

Physical Characteristics of Sediment-Trap Contents.................................. 106

Comparison of Sites by Use of Average Effect Concentrations..................... 107

Comparison of Sites by Use of Individual Contaminant Effects

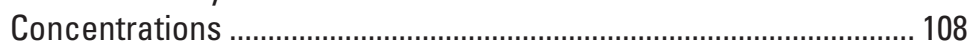

Comparison of Sites by Use of Total Phosphorus Enrichment ....................... 111

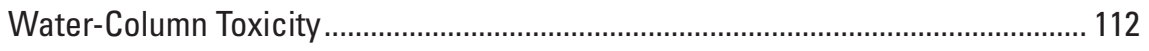

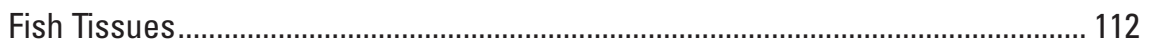

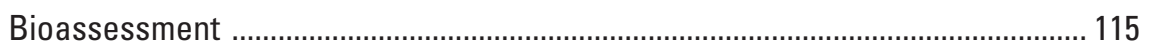

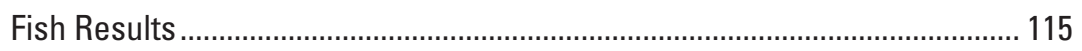

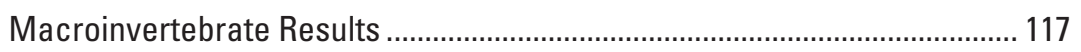

Algae Results...................................................................................... 122

Relations among Habitat Variables and Biotic Communities ........................ 124

Relations between Stream Biological Metrics, Site Characteristics, and

Water-Quality Data..................................................................................... 128

Potential Areas for Data Collection in Phase III ..................................................................... 133

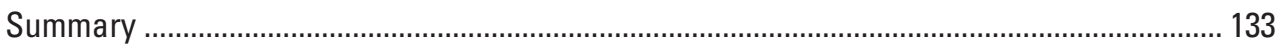

Summary of Relations between Biological Metrics, Site Characteristics, and Water-Quality Data........................................................................................... 133

Findings for Harbor Sites and the Milwaukee River at Mouth at Milwaukee Site ....... 134

Phase I-Phase II Comparisons ................................................................................... 134

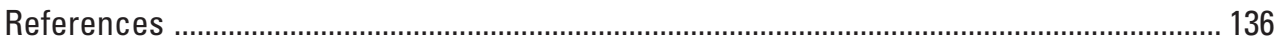

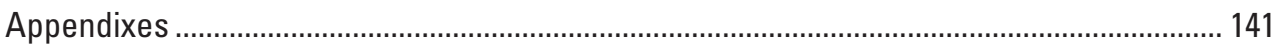




\section{Appendixes}

Appendix 1. Land-use classes from Southeastern Wisconsin Regional Planning Commission and Wisconsin Department of Natural Resources WISCLAND land-cover data sets

Appendix 2a-b. Descriptions of methods for harbor-site sampling and mercury sampling.

Appendix 3. Water-quality properties and constituents, reporting levels, and analyzing laboratories.

Appendix 4. Assignment of season and flow conditions, by site and by sampling event, for Phase II sampling in the Milwaukee Metropolitan Sewerage District planning area, Wisconsin, 2004-05. 158

Appendix 5. Comparison of median constituent concentrations and detections between Phase I and Phase II of the MMSD Corridor Study

Appendix 6. Hydrologic conditions during Phase II of the Milwaukee Metropolitan Sewerage District Corridor Study 


\section{Figures}

1-2. Maps showing:

1. Locations of sites sampled during Phase II in the Milwaukee

Metropolitan Sewerage District planning area, Wis.

2. Land use/land cover and stream-site drainage-area boundaries for stream sites sampled during Phase II of the Milwaukee Metropolitan Sewerage District Corridor Study.

3. Graph showing land use for Phase II sites of the Milwaukee Metropolitan Sewerage District Corridor Study

4. Map showing locations and characteristics of Phase II sampling sites, and locations of National Weather Service precipitation gages in the Milwaukee Metropolitan Sewerage District planning area, Wis.

5. Chart showing timeline of data-collection activities for Phase II of the Milwaukee Metropolitan Sewerage District Corridor Study.....

6. Photograph showing sediment traps used for collection of bed-sediment samples during Phase II of the Milwaukee Metropolitan Sewerage District Corridor Study

7-12. Graphs showing:

7. Inter-laboratory correlation between Phase II results for A, fecal coliform concentrations, and B, Escherichia coli concentrations from samples analyzed at the Wisconsin State Laboratory of Hygiene and Milwaukee Metropolitan Sewerage District.

8. Distribution of chloride concentrations, by site, in the Milwaukee Metropolitan Sewerage District planning area, Wis.

9. Median chloride concentrations plotted against percent urban land use in drainage basins for 15 stream sites in the Milwaukee Metropolitan Sewerage District planning area, Wis.

10. Distributions of chloride concentrations for stream and harbor samples, Milwaukee Metropolitan Sewerage District planning area, Wis..

11. Distribution of total nitrogen concentrations, by site, in the Milwaukee Metropolitan Sewerage District planning area, Wis.

12. Distributions of total nitrogen concentrations for stream and harbor samples, Milwaukee Metropolitan Sewerage District planning area, Wis.

13. Map showing Phase I and Phase II comparison of medi an total nitrogen concentrations in the Milwaukee Metropolitan Sewerage District planning area, Wis

14-15. Graphs showing:

14. Distribution of nitrate concentrations, by site, in the Milwaukee Metropolitan Sewerage District planning area, Wis.

15. Distributions of nitrate concentrations for stream and harbor samples, Milwaukee Metropolitan Sewerage District planning area, Wis

16. Map showing Phase I and Phase II comparison of median nitrate concentrations in the Milwaukee Metropolitan Sewerage District planning area, Wis. 
17-18. Graphs showing:

17. Distribution of total phosphorus concentrations, by site, in the Milwaukee Metropolitan Sewerage District planning area, Wis.

18. Distributions of total phosphorus concentrations for stream and harbor samples, Milwaukee Metropolitan Sewerage District planning area, Wis.

19. Map showing Phase I and Phase II comparison of median total phosphorus concentrations in the Milwaukee Metropolitan Sewerage District planning area, Wis.

20-52. Graphs showing:

20. Distribution of chlorophyll a concentrations, by site, in the Milwaukee

Metropolitan Sewerage District planning area, Wis.

21. Distributions of chlorophyll a concentrations for stream and harbor samples, Milwaukee Metropolitan Sewerage District planning area, Wis.

22. Distribution of suspended-sediment concentrations, by site, in the Milwaukee Metropolitan Sewerage District planning area, Wis. 52

23. Distributions of suspended-sediment concentrations for stream and harbor samples, Milwaukee Metropolitan Sewerage District planning area, Wis.

24. Median dissolved total mercury concentrations plotted against percent urban land use in site drainage basins for 15 stream sites in the Milwaukee Metropolitan Sewerage District planning area, Wis.

25. Median concentrations of total mercury, by site, in the Milwaukee Metropolitan Sewerage District planning area, Wis.

26. Median concentrations of methylmercury, by site, in the Milwaukee Metropolitan Sewerage District planning area, Wis.

27. Median concentrations of fecal coliform plotted against percent urban land use in site drainage basins for 15 stream sites in the Milwaukee Metropolitan Sewerage District planning area, Wis.

28. Distribution of fecal coliform concentrations, by site, in the Milwaukee

Metropolitan Sewerage District planning area, Wis.

29. Distributions of fecal coliform concentrations for stream and harbor sites, Milwaukee Metropolitan Sewerage District planning area, Wis.

30. Median concentrations of $E$. coli plotted against percent urban land use in site drainage basins for 15 stream sites in the Milwaukee Metropolitan Sewerage District planning area, Wis.

31. Distribution of $E$. coli concentrations, by site, in the Milwaukee Metropolitan Sewerage District planning area, Wis.

32. Distributions of $E$. coli concentrations for stream and harbor sites, Milwaukee Metropolitan Sewerage District planning area, Wis

33. Median concentrations of coliphage plotted against percent urban land use in site drainage basins for 15 stream sites in the Milwaukee Metropolitan Sewerage District planning area, Wis.

34. Distribution of coliphage concentrations, by site, in the Milwaukee Metropolitan Sewerage District planning area, Wis.

35. Distributions of coliphage concentrations for stream and harbor sites, Milwaukee Metropolitan Sewerage District planning area, Wis. 


\section{Figures (cont.)}

36. Detection frequency of coliphage groups II and (or) III in samples, by site, in the Milwaukee Metropolitan Sewerage District planning area, Wis.

37. Detection frequencies of coliphage groups II and (or) III detections for stream and harbor sites, Milwaukee Metropolitan Sewerage District planning area, Wis

38. Detection frequencies and concentrations of Salmonella in samples, by site, in the Milwaukee Metropolitan Sewerage District planning area, Wis.

39. Detection frequencies and concentrations of Salmonella for stream sites, Milwaukee Metropolitan Sewerage District planning area, Wis. ......... 75

40. Detection frequencies and concentrations of Giardia in samples by site in the Milwaukee Metropolitan Sewerage District planning area, Wis

41. Detection frequencies and concentrations of Giardia for stream and harbor sites, Milwaukee Metropolitan Sewerage District planning area, Wis.

42. Detection frequencies and concentrations of Cryptosporidium in samples, by site, in the Milwaukee Metropolitan Sewerage District planning area, Wis.

43. Detection frequencies and concentrations of Cryptosporidium for stream and harbor sites, Milwaukee Metropolitan Sewerage District planning area, Wis.

44. Detection frequencies of selected classes of Group 1 wastewater compounds (polycyclic aromatic hydrocarbons, antioxidants, plasticizers, dyes and pigments, and fire retardants), by site, in the Milwaukee Metropolitan Sewerage District planning area, Wis

45. Detection frequencies of Group 2 solvent and fuel wastewatercompound classes, by site, in the Milwaukee Metropolitan Sewerage District planning area, Wis

46. Detection frequencies of Group 3 insecticide and herbicide wastewater-compound classes, by site, in the Milwaukee Metropolitan Sewerage District planning area, Wis

47. Detection frequencies of selected classes of Group 4 wastewater compounds (flavors and fragrances, nonprescription human drugs, antimicrobial disinfectants, detergent metabolites, and sterols), by site, in the Milwaukee Metropolitan Sewerage District planning area, Wis.

48. Detection frequency of stream samples with wastewater-compound detections during high-and low-flow periods, by WWC class, in the Milwaukee Metropolitan Sewerage District planning area, Wis

49. Detection frequency of stream samples with wastewater-compound detections, by season and WWC class, in the Milwaukee Metropolitan Sewerage District planning area, Wis.

50. Detection frequency of stream samples with wastewater-compound detections during low-flow periods, by season and WWC class, in the Milwaukee Metropolitan Sewerage District planning area, Wis 
51. Detection frequency of stream samples with wastewater-compound detections during high-flow periods, by season and WWC class, in the Milwaukee Metropolitan Sewerage District planning area, Wis. 99

52. Detection frequency of harbor samples with wastewater-compound detections, by season and WWC class, in the Milwaukee Metropolitan Sewerage District planning area, Wis.

53. Map showing distribution and frequency of known and suspected endocrine-disrupting compounds in the Milwaukee Metropolitan Sewerage District planning area, Wis. 103

54-59. Graphs showing:

54. Mass and particle-size distribution of sediment captured in Phase II sediment traps in the Milwaukee Metropolitan Sewerage District planning area, Wis

55. Particle-size distribution in sediment-trap samples, by Phase II sampling location, in the Milwaukee Metropolitan Sewerage District planning area, Wis

56. Number of consensus-based threshold effect concentration exceedences and the mean consensus-based probable effects concentration quotients for contaminants in sediments from the Milwaukee Metropolitan Sewerage District planning area, Wis

57. Consensus-based probable effects concentration quotients for nine contaminants in the Milwaukee Metropolitan Sewerage District planning area, Wis

58. Total phosphorus enrichment factor relative to background upland soil concentrations in the Milwaukee Metropolitan Sewerage District planning area, Wis.

59. Fish Index of Biotic Integrity scores plotted against percent urban land use in site drainage basins for 15 stream sites in the Milwaukee Metropolitan Sewerage District planning area, Wis.

60. Map showing sites sampled for macroinvertebrates with percent Ephemeroptera, Plecoptera, and Trichoptera taxa in the Milwaukee Metropolitan Sewerage District planning area, Wis

61. Graph showing percent Ephemeroptera, Plecoptera, and Trichoptera taxa plotted against percent urban land use in site drainage basins for 15 stream sites in the Milwaukee Metropolitan Sewerage District planning area, Wis.

62. Map showing sites sampled for macroinvertebrates with Hilsenhoff Biotic Index in the Milwaukee Metropolitan Sewerage District planning area, Wis.

63-65. Graphs showing:

63. A modified Hilsenhoff Biotic Index (HBI-10) plotted against percent urban land use in site drainage basins for 15 stream sites in the Milwaukee Metropolitan Sewerage District planning area, Wis.

64. Percentage of diatoms in pollution-tolerance classes in the Milwaukee Metropolitan Sewerage District planning area, Wis.

65. Percent pollution-sensitive diatoms plotted against percent urban land use in site drainage basins for 15 stream sites in the Milwaukee Metropolitan Sewerage District planning area, Wis. 


\section{Tables}

1A. Basin characteristics and streamflow statistics for stream sites sampled during Phase II of the Milwaukee Metropolitan Sewerage District Corridor Study

1B. Harbor sites sampled during Phase II of the Milwaukee Metropolitan Sewerage District Corridor Study

2. List of properties and constituents analyzed during Phase II of the Milwaukee Metropolitan Sewerage District Corridor Study

3. Results of constituent detections in field blanks during Phase II of the Milwaukee Metropolitan Sewerage District Corridor Study... 16

4. Results of replicated sample issues during Phase II of the Milwaukee Metropolitan Sewerage District Corridor Study...

5. Replicate results for indicator organisms analyzed by Wisconsin State Laboratory of Hygiene during Phase II of the Milwaukee Metropolitan Sewerage District Corridor Study

6. Replicate results for pathogenic organisms during Phase II of the Milwaukee Metropolitan Sewerage District Corridor Study....

7. Relative percent differences in sediment-trap results for six sites in Phase II of the Milwaukee Metropolitan Sewerage District Corridor Study...

8. Comparison of the Phase I subwatersheds to Phase II sites of the Milwaukee Metropolitan Sewerage District Corridor Study...

9. Monthly and water-year totals for rain gages in the Milwaukee Metropolitan Sewerage District planning area, Wis.

10. Median results for field measurements, major inorganics, and alkalinity that did not indicate any unusual water-quality patterns.....

11. Annual chloride load and yield, average daily chloride yield, total water flow, and volumetric total chloride concentrations for four Phase II sites in the Milwaukee Metropolitan Sewerage District planning area, Wis.

12. Monthly and annual chloride loads for four Phase II sites in the Milwaukee Metropolitan Sewerage District planning area, Wis., for water years 2004 and 2005 .

13. Estimated nutrient concentrations in reference streams for the area encompassing the Milwaukee Metropolitan Sewerage District planning area, Wis.

14. Annual total phosphorus load and yield, average daily phosphorus yield, total water flow, and volumetric total phosphorus concentrations for four Phase II sites in the Milwaukee Metropolitan Sewerage District planning area, Wis.

15. Monthly and annual total phosphorus loads for four Phase II sites in the Milwaukee Metropolitan Sewerage District planning area, Wis., for water years 2004 and 2005

16. Annual suspended-sediment load and yield, average daily sediment yield, total water flow, and volumetrically weighted sediment concentrations for four Phase II sites in the Milwaukee Metropolitan Sewerage District planning area, Wis.

17. Monthly and annual suspended-sediment loads for four Phase II sites in the Milwaukee Metropolitan Sewerage District planning area, Wis., for water years 2004 and 2005 
18. Summary of detections and nondetections of wastewater compounds at all Phase II sites in the Milwaukee Metropolitan Sewerage District planning area, Wis.

19. Grouping of wastewater-compound classes for Phase II of the Milwaukee Metropolitan Sewerage District Corridor Study..... 84

20. Summary of analtyical results of stream and harbor sites sampled for wastewater compounds during Phase II of the Milwaukee Metropolitan Sewerage District Corridor Study...

21. Detection frequencies for Phase II wastewater compounds analysis in the Milwaukee Metropolitan Sewerage District planning area, Wis.

22. Results for toxicity tests and selected chemical analyses of semipermeable membrane device extracts and detection frequencies for Phase II wastewater-compounds analysis at seven sites in the Milwaukee Metropolitan Sewerage District.

23. Maximum total polychlorinated biphenyl concentrations in sediment-trap samples for 15 Phase II stream sites collected during two surveys of the Milwaukee Metropolitan Sewerage District Corridor Study

24. Percent effects in samples with readings at or above 20 percent for all Phase II sites in the Milwaukee Metropolitan Sewerage District planning area, Wis.

25. Summary of chemical analysis of whole fish at three Phase II stream sites of the Milwaukee Metropolitan Sewerage District Corridor Study, during one-time surveys conducted in October, 2004.

26. Biotic integrity ratings for Index of Biotic Integrity score 115

27. Fish-community information from one-time surveys conducted during July, August, and October 2004, for 14 Phase II stream sites in the Milwaukee Metropolitan Sewerage District planning area, Wis.

28. Water-quality ratings for Hilsenhoff Biotic Index and $\mathrm{HBI}-10$ values

29. Macroinvertebrate community information from one-time surveys conducted during August and September 2004, for 14 Phase II stream sites in the Milwaukee Metropolitan Sewerage District planning area, Wis.

30. Algal-community results from one-time surveys conducted in August and September 2004, for 14 Phase II stream sites in the Milwaukee Metropolitan Sewerage District planning area, Wis

31. Correlations among metrics of aquatic biology and selected habitat metrics for Phase II of the Milwaukee Metropolitan Sewerage District Corridor Study

32. Average trophic-level rankings and aggregate bioassessment rankings for Phase II stream sites in the Milwaukee Metropolitan Sewerage District planning area, Wis.

33. Summarized results of Phase II constituents, grouped by aggregate bioassessment ranking in the Milwaukee Metropolitan Sewerage District planning area, Wis. 


\section{Conversion Factors and Abbreviations}

\begin{tabular}{|c|c|c|}
\hline Multiply & By & To obtain \\
\hline \multicolumn{3}{|c|}{ Length } \\
\hline inch (in.) & 2.54 & centimeter $(\mathrm{cm})$ \\
\hline foot (ft) & 0.3048 & meter $(\mathrm{m})$ \\
\hline mile (mi) & 1.609 & kilometer $(\mathrm{km})$ \\
\hline \multicolumn{3}{|c|}{ Area } \\
\hline square mile $\left(\mathrm{mi}^{2}\right)$ & 2.590 & square kilometer $\left(\mathrm{km}^{2}\right)$ \\
\hline \multicolumn{3}{|c|}{ Volume } \\
\hline milliliter $(\mathrm{mL})$ & 0.03381 & ounce, fluid (fl. oz) \\
\hline liter (L) & 0.2642 & gallon (gal) \\
\hline \multicolumn{3}{|c|}{ Flow rate } \\
\hline cubic foot per second $\left(\mathrm{ft}^{3} / \mathrm{s}\right)$ & 0.02832 & cubic meter per second $\left(\mathrm{m}^{3} / \mathrm{s}\right)$ \\
\hline \multicolumn{3}{|c|}{ Mass } \\
\hline $\operatorname{gram}(\mathrm{g})$ & 0.03527 & ounce, avoirdupois (oz) \\
\hline pound, avoirdupois (lb) & 0.4536 & kilogram $(\mathrm{kg})$ \\
\hline ton, short $(2,000 \mathrm{lb})$ & 0.9072 & megagram $(\mathrm{Mg})$ \\
\hline pound per square mile $\left(\mathrm{lb} / \mathrm{mi}^{2}\right)$ & 0.1751 & $\begin{array}{l}\text { kilogram per square kilometer } \\
\left(\mathrm{kg} / \mathrm{km}^{2}\right)\end{array}$ \\
\hline ton per square mile $\left(\operatorname{ton} / \mathrm{mi}^{2}\right)$ & 0.3503 & $\begin{array}{l}\text { megagram per square kilometer } \\
\left(\mathrm{Mg} / \mathrm{km}^{2}\right)\end{array}$ \\
\hline $\begin{array}{l}\text { ton per day per square mile } \\
{\left[(\text { ton } / \mathrm{d}) / \mathrm{mi}^{2}\right]}\end{array}$ & 0.3503 & $\begin{array}{l}\text { megagram per day per square } \\
\text { kilometer }\left[(\mathrm{Mg} / \mathrm{d}) / \mathrm{km}^{2}\right]\end{array}$ \\
\hline
\end{tabular}

Temperature in degrees Celsius $\left({ }^{\circ} \mathrm{C}\right)$ may be converted to degrees Fahrenheit $\left({ }^{\circ} \mathrm{F}\right)$ as follows:

$$
{ }^{\circ} \mathrm{F}=\left(1.8 x^{\circ} \mathrm{C}\right)+32
$$

Specific conductance is given in microsiemens per centimeter at 25 degrees Celsius $\left(\mu \mathrm{S} / \mathrm{cm}\right.$ at $\left.25^{\circ} \mathrm{C}\right)$.

Concentrations of chemical constituents in water are given either in milligrams per liter (mg/L), micrograms per liter ( $\mu \mathrm{g} / \mathrm{L})$, or nanograms per liter $(\mathrm{ng} / \mathrm{L})$. Concentrations of chemical constituents in sediment are given in milligrams per kilogram $(\mathrm{mg} / \mathrm{kg})$ and in fish tissue are given in micrograms per gram $(\mu \mathrm{g} / \mathrm{g})$.

Concentrations of microbiological constituents in water are given in the following units: fecal coliform bacteria, colonies per 100 milliliters (col/100 mL); Escherichia coli and Salmonella, most probable number per 100 milliliters (MPN/100 mL); coliphage, plaques per 100 milliliters (plaques/100 mL); Giardia, cysts per 100 liters (cysts/100 L); Cryptosporidium, oocysts per 100 liters (oocysts/100 L).

Reporting level refers to the minimum concentrations reported by laboratories for analytical results. In this report, reporting level is used as a general term encompassing more specific reporting standards (for example, minimum reporting level, interim reporting level, method detection limit, detection level, etc.). For detailed information regarding specific constituents, please consult with the analyzing laboratory listed in appendix 3. 


\section{Other Abbreviations}

$\begin{array}{ll}\text { DF } & \text { Detection frequency } \\ \text { EDC } & \text { Endocrine-disrupting compound } \\ \text { EPT } & \text { Ephemeroptera-Plecoptera-Trichoptera taxa } \\ \text { HBI } & \text { Hilsenhoff Biotic Index } \\ \text { IBI } & \text { Index of Biotic Integrity } \\ \text { LOD } & \text { Level of detection } \\ \text { MPN } & \text { Most probable number } \\ \text { PAH } & \text { Polycyclic aromatic hydrocarbon } \\ \text { PCB } & \text { Polychlorinated biphenyl } \\ \text { PEC } & \text { Probable effects concentration } \\ \text { RPD } & \text { Relative percent difference } \\ \text { SPMD } & \text { Semipermeable membrane device } \\ \text { TEC } & \text { Threshold effect concentration } \\ \text { VOC } & \text { Volatile organic compound } \\ \text { VW } & \text { Volumetrically weighted } \\ \text { WWC } & \text { Wastewater compound }\end{array}$




\section{Acknowledgments}

\section{Technical Reviewers}

Dale M. Robertson, Research Hydrologist (Chemistry), U.S. Geological Survey, Middleton, Wis.

Herbert S. Garn, Assistant Center Director, U.S. Geological Survey, Middleton, Wis.

Eric Waldmer, Water Resources/Aquatic Biology Supervisor, Milwaukee Metropolitan Sewerage District, Milwaukee, Wis.

Chris Magruder, Community and Environmental Liaison, Milwaukee Metropolitan Sewerage District, Milwaukee, Wis.

\section{Editorial and Graphics}

Michael Eberle, Technical Publications Editor, U.S. Geological Survey, Columbus, Ohio S. Bridgett Marsh, Hydrologist, U.S. Geological Survey, Middleton, Wis.

Michelle Greenwood, Geographer, U.S. Geological Survey, Middleton, Wis.

\section{Data Collection}

Troy D. Rutter, Hydrologic Technician, U.S. Geological Survey, Middleton, Wis. Krista A. Stensvold, Hydrologist, U.S. Geological Survey, Middleton, Wis. Timothy L. Hanson, Hydrologic Technician, U.S. Geological Survey, Middleton, Wis. U.S. Geological Survey and Milwaukee Metropolitan Sewerage District field and laboratory personnel

\section{Approving Official}

Dorothy H. Tepper, Northeast Region Reports Improvement Advisor, U.S. Geological Survey, Reston, Va. 


\title{
Water-Quality Characteristics for Selected Sites within the Milwaukee Metropolitan Sewerage District Planning Area, Wisconsin, February 2004-September 2005
}

\author{
By Judith C. Thomas, Michelle A. Lutz, Jennifer L. Bruce, David J. Graczyk, Kevin D. Richards, \\ David P. Krabbenhoft, Stephen M. Westenbroek, Barbara C. Scudder, Daniel J. Sullivan, \\ and Amanda H. Bell
}

\section{Abstract}

The Milwaukee Metropolitan Sewerage District (MMSD) Corridor Study is a three-phase project designed to improve the understanding of water resources in the MMSD planning area to assist managers and policy makers in their decisions. Phase I of the Study involved the compilation of existing data from multiple agencies into a single database. These data were analyzed to identify spatial, temporal, and technological gaps in the planning area, and were used to develop Phase II of the Study. Phase II, the subject of this report, involved an intensive data-collection effort by the U.S. Geological Survey (USGS) in cooperation with MMSD (from February, 2004, through September, 2005). This phase addressed the data gaps identified in Phase I and completed a baseline assessment of water quality for selected stream and harbor sites in the MMSD planning area. This baseline assessment included evaluations of surface-water chemistry and microbial concentrations in the streams and harbor sites; additionally, stream sites were evaluated for discharge, sediment chemistry, fish-tissue chemistry, habitat, and the quality of biological communities (including fish, macroinvertebrates, and algae). In all, data were collected at 15 stream and 6 harbor sites within the MMSD planning area, including manual sampling and analysis for more than 220 water-quality properties and constituents at all 21 sites, stream-discharge data for 14 stream sites, and automated water-quality sampling at 4 stream sites. A bioassessment during autumn 2004 included collection of biologic-community data and stream-habitat data at wadeable streams.

Quartiles of Phase II aggregate bioassessment rankings were used to divide the 14 wadeable stream sites into four groups to investigate relations between bioassessment data and site characteristic and water-quality data. Quartile numbers reflect relative water quality: quartile 1 contained sites where the bioassessment data indicated the leastdegraded water quality among those sampled, and quartile 4 contained sites that indicated the most-degraded water quality. Quartiles contained the following stream sites:

- Quartile 1: Milwaukee River near Cedarburg, Milwaukee River at Milwaukee, Jewel Creek, and Menomonee River at Menomonee Falls;

- Quartile 2: Willow Creek, Root River near Franklin, and Root River at Grange Avenue;

- Quartile 3: Menomonee River at Wauwatosa, Oak Creek, and Little Menomonee River; and

- Quartile 4: Honey Creek, Underwood Creek, Lincoln Creek, and Kinnickinnic River.

Site characteristics (in this case, drainage area and land use) and selected water-quality data were summarized based on the four bioassessment quartiles to determine if there were relations with the aggregate bioassessment rankings. In general, sites having the largest drainage basins with the lowest proportion of urban land use were in quartile 1 , and the smallest drainage basins with the highest proportion of urban land use were in quartile 4. Major ions, indicator organisms, and wastewater compounds generally had the lowest overall results in quartile 1 and highest overall results in quartile 4 , with intermediate results in quartiles 2 and 3. Results for other constituent types (nutrients, mercury, pathogenic organisms, and bed sediment) were mixed, with results for some constituents decreasing from quartile 1 to quartile 4 . 
Where sufficient Phase I data were available, summary statistics (including medians) for chemical and biological data were calculated, allowing some comparisons to be made between Phase I and Phase II data. Comparisons between Phase I and Phase II results indicated a variety of changes with respect to water quality. Concentrations of chloride, nitrate, chlorophyll $a$, total phosphorus in water; arsenic in bed sediment; and fish Index of Biotic Integrity ratings generally indicated declines in water quality. However, concentrations of total nitrogen, suspended sediment, and fecal coliform in water; some trace elements (cadmium, chromium, copper, lead, mercury, nickel, and zinc) in bed sediment; Ephemeroptera-Plecoptera-Trichoptera taxa and Hilsenhoff Biotic Index ratings indicated improvements in water quality between Phase I and Phase II.

Polychlorinated biphenyls (PCBs) were measured in bed sediment (15 sites) and fish tissue ( 3 sites) to determine if there were changes in concentrations between Phase I and Phase II. PCB contamination of bed sediment and fish tissue was found during both Phase I and Phase II for the Milwaukee River at Milwaukee sampling site. PCB contamination of the Menomonee River at Wauwatosa site was limited to bed sediment during Phase I, but was found in both bed sediment and fish tissue during Phase II. Samples collected at Root River near Franklin contained no detectable concentrations of PCBs in fish tissue or bed sediment (data available for Phase II only).

Historically used pesticides were measured in fish tissue at three sites to determine if there were changes in concentrations between Phase I and Phase II. Historically used pesticides were detected in fish tissue at the Milwaukee River at Milwaukee site during Phase I; however Phase II concentrations were less than the Phase I reporting level. Historically used pesticides were also detected in fish-tissue samples at the Menomonee River at Wauwatosa site during Phase II, while none were detected in Phase I. Root River near Franklin had no pesticide detections in fish tissue in Phase I or Phase II.

\section{Introduction}

Stream ecosystems are impacted by anthropogenic changes on the land surface. Stream-water quality and the quality of biological communities in urban-stream corridors are complex issues that drive research, regulation, and the use of rivers and streams. Personnel from Federal, state, and local agencies and universities involved with such issues in southeastern Wisconsin have worked cooperatively to assess the recent history of urban streams and to use that knowledge to evaluate future stream-improvement projects. This collaboration will help the various parties to determine the likely success of proposed projects prior to implementation and will allow projects with greatest potential to receive priority. With the expertise of professionals from the planning, regulatory, and nonregulatory fields, as well as academicians and engineers, the Milwaukee Metropolitan Sewerage District (MMSD) Corridor Study has taken a broad-based approach to promote sound, resource-based management decisions (Schneider and others, 2004).

The MMSD Corridor Study is a three-phase project designed to improve the understanding of water resources in the MMSD planning area (fig. 1). This study is a collaborative effort by MMSD, the Wisconsin Department of Natural Resources (WDNR), the Southeastern Wisconsin Regional Planning Commission (SEWRPC), the U.S. Geological Survey (USGS), the University of WisconsinMilwaukee, Marquette University, and Wisconsin Lutheran College. The Corridor Study is designed to evaluate the quality of water resources and biological communities of stream corridors within the MMSD planning area and to provide information to assess the potential success of current and future projects.

An MMSD stream corridor is defined as the land between a natural or artificial channel and either (1) the SEWRPC primary or secondary environmental-corridor ${ }^{1}$ boundary, (2) the 100-year regulatory floodplain boundary, (3) the edge of an adjoining wetland, or (4) a distance of 75 feet, whichever is the greatest distance from the stream channel or shoreline.

\footnotetext{
${ }^{1}$ Areas of concentrated natural resources (for example, lakes, streams, undeveloped shorelands, and floodplains) delineated by SEWRPC and used to make development recommendations to local governments (Uni-
versity of Wisconsin-Extension and Southeastern Wisconsin Regional used to make development recommendations to local governments (Uni-
versity of Wisconsin-Extension and Southeastern Wisconsin Regional Planning Commission, 2004).
} 


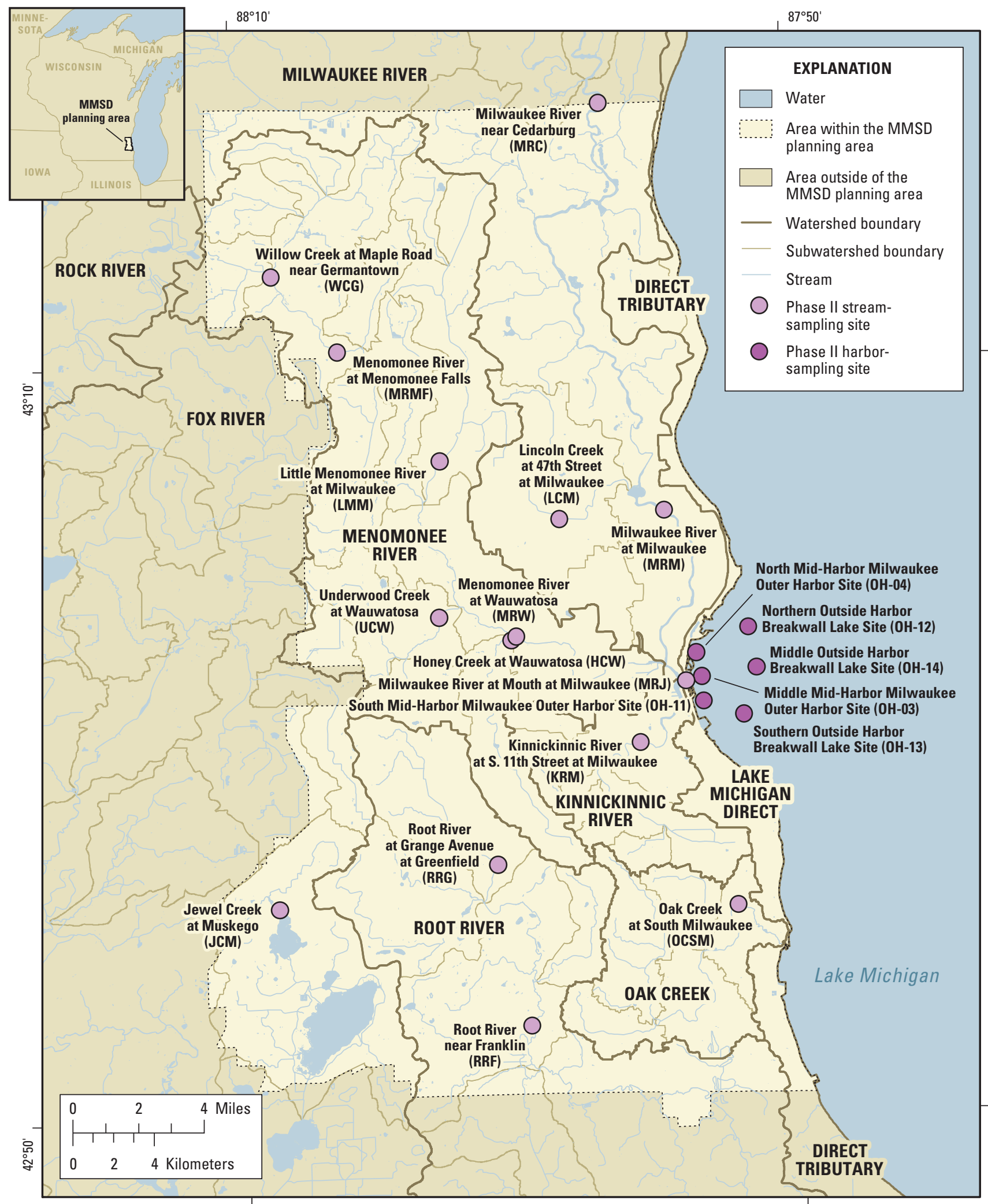

Base composited from Southeastern Wisconsin Regional Planning Commission regional base map, 1:2,000, 1995; U.S. Geological Survey digital line graph hydrography, 1:100,000, 1989; Wisconsin Department of Natural Resources version 2 hydrography, 1:24,000, 2002. Wisconsin Transverse Mercator Projection, referenced to North American Datum of 1983, 1991 adjustment.

Figure 1. Locations of sites sampled during Phase II in the Milwaukee Metropolitan Sewerage District (MMSD) planning area, Wis. Site abbreviations listed in table 1. 
The objectives of the MMSD Corridor Study are the following:

1. Evaluate historical results and assess potential effects of planned MMSD projects. Types of projects to be evaluated include, but are not limited to, historical and planned flood-control projects that involve the modification of stream channels and (or) their corridors by deepening, widening, or enclosing; the placement or removal of material or structures on the channel or its corridor; habitat enhancements; structure removal; land purchases for conservation purposes; and water-pollutionabatement projects.

2. Create a comprehensive inventory of corridor conditions. Develop an improved understanding of the interrelationship of stream physiographic, hydrologic, hydraulic, biologic, water-quality, sedimentquality, habitat, and land-use variables.

3. Establish a baseline assessment of existing stream and corridor conditions. Detect impairments for each reach.

4. Determine the existing and potential water-use objectives for stream reaches.

5. Evaluate the success of flood-control, habitat, and water-quality improvement or protection projects; evaluate current technologies; and identify adjustments for future projects.

6. Implement long-term surveillance of stream and corridor conditions to quantify project results, track changes in impaired and unimpaired reaches, provide additional inventory information, and facilitate early detection of newly impaired reaches. (Schneider and others, 2004)

The Study was designed to be completed in three phases. Phase I was a data compilation, review, and summary effort that involved the development of a database to store data collected in the stream corridors of the MMSD planning area from 1970 through 2002. No additional data were collected as part of Phase I. The MMSD Corridor Study database contains data from MMSD, USGS, WDNR, and the U.S. Environmental Protection Agency (USEPA). A report prepared as part of Phase I summarized data in the database by subwatershed and identified data gaps in the planning area (Schneider and others, 2004; Southeastern Wisconsin Regional Planning Commission, 2002b).
Phase II consisted of an intensive data-collection effort intended to fill in the data gaps identified in Phase I, including the prevalence of emerging contaminants not previously investigated (Schneider and others, 2004), to create a baseline assessment of stream corridor conditions in the MMSD planning area. Data collected during Phase II has been incorported into the MMSD Corridor Study database. Additional data sets, including some supplied by local universities and volunteer groups, continue to be incorporated into the database as they become available. The MMSD corridor database is available to those within the cooperating agencies to assist in informal decisionmaking processes.

Phase III will involve data-collection efforts at a subset of the Phase II sites, focusing on specific investigations related to selected constituents. In addition, Phase III will continue to monitor the quality of biological communities to document changes in overall stream corridor condition.

\section{Purpose and Scope}

This report summarizes the data collected as part of Phase II of the MMSD Corridor Study at 15 stream sites and 6 harbor sites in the MMSD planning area from February 2004 through September 2005. The objectives of Phase II were:

1. Identification of stream and harbor sites for data collection;

2. Collection of discharge data for selected streams within the MMSD planning area;

3. Collection of additional water-quality data;

4. Computation of chloride, total phosphorus, and suspended sediment loads at four streams in the MMSD planning area; and

5. Collection of biological-community and habitat data at wadeable stream sites.

Descriptions of Phase II study design, field and analytical methods, patterns of response to hydrology and seasons, and general comparisons to Phase I data summaries are also provided in this report.

Water-chemistry data were collected at all stream and harbor sites, and included measurements of chloride, nutrients, chlorphyll $a$, suspended sediment, mercury, indicator and pathogenic organisms, pesticides, and wastewater compounds. Sediment chemistry data were collected at all 15 stream sites, and included total polychlorinated biphenyls (PCBs), total phosphorus, particle-grain size, arsenic, cadmium, chromium, copper, lead, mercury, nickel, and zinc. Biological data (fish-, macroinvertebrate-, and algalcommunity surveys; and habitat measures) and physical 
data (discharge) were collected at the 14 wadeable stream sites. In addition to data collected in conjunction with the Phase II sampling effort, data for semi-permeable membrane devices (SPMDs) were collected in 2004 at or near 7 of the Phase II sites by the USGS National Water-Quality Assessment Program Effects of Urbanization on Stream Ecosystem study.

\section{Study Design, Sample Collection, and Results of Quality Assurance}

Data collection during Phase II of the MMSD Corridor Study was a collaborative effort between USGS and MMSD field personnel. A total of 15 stream sites and 6 harbor sites were sampled (fig. 1, tables 1A-B) during water years 2004 and $2005^{2}$. All stream sites were within the MMSD planning area. The site at the mouth of the Milwaukee River (Milwaukee River at Mouth at Milwaukee, 04087170) receives water from the Milwaukee, Menomonee, and Kinnickinnic River watersheds in addition to water from Lake Michigan (by way of reverse flow). Oak Creek and Root River both discharge directly into Lake Michigan south of the Milwaukee Harbor. Jewel Creek discharges into the Mississippi River by way of the Fox and Illinois Rivers. Of the six harbor sites sampled, three sites were inside the breakwall (inner harbor sites) and three sites were outside the breakwall (outer harbor sites). Samples were collected manually at all sites, and additional samples were collected automatically at four of the stream sites.

\section{Land Use and Phase II Sites}

Land use for Phase II stream-site drainage basins was determined by means of a Geographic Information System (GIS). Drainage-basin boundaries were primarily derived from the Southeastern Wisconsin Regional Planning Commission (SEWRPC) Subbasin layer (2002a). For sites not on SEWRPC Subbasin boundaries (Southeastern Wisconsin Regional Planning Commission, 2002a), USGS 1:24,000 topographic maps were used to delineate the most downstream boundary. Resulting polygons were intersected with land-use layers. Land-use information was derived primarily from the SEWRPC digital land-use layer (2000). This layer did not incorporate the most upstream

\footnotetext{
${ }^{2}$ Water year is a 12-month period from October 1 through September 30, and is designated by the calendar year in which it ends (for example, the 2004 water year occurred October 1, 2003 through September 30, 2004).
}

parts of the Milwaukee River drainage basin; therefore, upstream parts of this drainage basin were obtained from the WISCLAND land-cover layer (Wisconsin Department of Natural Resources, 1998); resultant data were combined with data obtained from the SEWRPC digital land-use layer to yield land-use information for these sites (Milwaukee River near Cedarburg, Milwaukee River at Milwaukee, and Milwaukee River at Mouth). Data for each drainage basin were summarized into basic categories (appendix 1).

The 15 stream sites were selected to fill spatial, temporal, and technological data gaps identified in Phase I analysis. Sites spanned a wide range of drainage areas and land uses (table 1A, fig. 2). Drainage areas ranged from 6.33 to $872 \mathrm{mi}^{2}$, while land use ranged from predominantly urban to predominantly agricultural and natural areas (fig. 3). Land-use types were highly correlated with one another; therefore it was not possible to observe the direct effects of individual land-use types (especially the types of urban land use). Urban land-use types were grouped together into a single total urban land-use category which was made up of transportation, residential, commercial, industrial, and other urban land uses. Because land-use types were highly correlated with one another, including natural area and agricultural land uses, all comparisons were made to total urban land use. Two Superfund sites in the Milwaukee area are discussed in this report in conjunction with Phase II site results:

1. Moss-American Co., Inc. (Kerr-McGee Oil Co.)(U.S. Environmental Protection Agency ID: WID039052626), Milwaukee. The types of contaminants at this site are polycyclic aromatic hydrocarbons (PAHs) and volatile organic compounds (VOCs) in bed sediment. (U.S. Environmental Protection Agency, 2006c). This site is upstream of the Little Menomonee River site sampled during Phase II.

2. Cedar Creek (U.S. Environmental Protection Agency ID: WID988590261) at Cedarburg. This is a Superfund alternative site; primary contaminants at this site are PCBs in bed sediment (U.S. Environmental Protection Agency, 2006b). Cedar Creek is a tributary to the Milwaukee River and is upstream from the Phase II Milwaukee River sites.

There are three wastewater treatment plants (WWTPs) in the planning area: the Jones Island Wastewater Treatment Plant, the South Shore Wastewater Treatment Plant, and the City of South Milwaukee Wastewater Treatment Facility. None of these WWTPs discharge into streams sampled in Phase II. 
Table 1A. Basin characteristics and streamflow statistics for stream sites sampled during Phase II of the Milwaukee Metropolitan Sewerage District Corridor Study.

$\left[\mathrm{mi}^{2}\right.$, square mile; $\mathrm{ft}^{3} / \mathrm{s}$, cubic foot per second; Q, discharge; WQ, water quality; --, not available; site locations shown in fig. 1]

\begin{tabular}{|c|c|c|c|c|c|c|c|}
\hline \multirow{2}{*}{ Stream site name } & \multirow{2}{*}{$\begin{array}{c}\text { Site } \\
\text { abbreviation }\end{array}$} & \multirow{2}{*}{ Site number } & \multirow{2}{*}{$\begin{array}{l}\text { Drainage area } \\
\qquad\left(\mathrm{mi}^{2}\right)\end{array}$} & \multirow{2}{*}{$\begin{array}{c}\text { Period of } \\
\text { discharge record }\end{array}$} & \multicolumn{3}{|c|}{$\begin{array}{c}\text { Percent exceedence }{ }^{c} \\
\left(\mathrm{ft}^{3} / \mathrm{s}\right)\end{array}$} \\
\hline & & & & & 10 & 50 & 90 \\
\hline $\begin{array}{l}\text { Milwaukee River near } \\
\text { Cedarburg }^{\text {a }}\end{array}$ & MRC & 04086600 & 607 & $1981-2005$ & 965 & 276 & 113 \\
\hline $\begin{array}{l}\text { Lincoln Creek at } 47 \text { th Street at } \\
\text { Milwaukee }\end{array}$ & LCM & $\begin{array}{l}040869416(Q) \\
040869415(W Q)\end{array}$ & 9.56 & $\begin{array}{c}1993-95,1997 \\
\text { 2002-2004 }\end{array}$ & 28 & 3.9 & 1.5 \\
\hline $\begin{array}{l}\text { Milwaukee River at } \\
\text { Milwaukee }^{\mathrm{a}}\end{array}$ & MRM & 04087000 & 690 & 1914-2005 & 985 & 231 & $73^{d}$ \\
\hline $\begin{array}{l}\text { Willow Creek at Maple Road } \\
\text { near Germantown }\end{array}$ & WCG & 040870195 & 6.33 & $\begin{array}{l}\text { Miscellaneous } \\
\text { measurements }\end{array}$ & -- & -- & -- \\
\hline $\begin{array}{l}\text { Menomonee River at } \\
\text { Menomonee Falls }\end{array}$ & MRMF & 04087030 & 34.7 & $\begin{array}{l}\text { 1974-1977, } \\
1979-2005\end{array}$ & 65 & 14 & 4.0 \\
\hline $\begin{array}{l}\text { Little Menomonee River } \\
\text { at Milwaukee }\end{array}$ & LMM & 04087070 & 19.7 & $\begin{array}{l}\text { 1975-77, } \\
\text { 2004-2005 }\end{array}$ & 37 & 4.3 & 0.54 \\
\hline $\begin{array}{l}\text { Underwood Creek at } \\
\text { Wauwatosa }\end{array}$ & UCW & 04087088 & 18.2 & $\begin{array}{r}1974-1979, \\
1980-2005\end{array}$ & 30 & 6.9 & 3.0 \\
\hline Honey Creek at Wauwatosa & $\mathrm{HCW}$ & 04087119 & 10.3 & $\begin{array}{l}\text { 1975-81, } \\
2004-2005\end{array}$ & 20 & 2.5 & 1.1 \\
\hline $\begin{array}{l}\text { Menomonee River at } \\
\text { Wauwatosa }^{\mathrm{a}}\end{array}$ & MRW & 04087120 & 123 & $1961-2005$ & 235 & 44 & $14^{\mathrm{d}}$ \\
\hline $\begin{array}{l}\text { Kinnickinnic River at } \\
\text { S. 11th Street at Milwaukee }\end{array}$ & KRM & 04087159 & 18.8 & 1982-2005 & 48 & 9.2 & 5.3 \\
\hline $\begin{array}{l}\text { Milwaukee River at Mouth } \\
\text { at Milwaukee }\end{array}$ & MRJ & 04087170 & 872 & $\begin{array}{l}\text { 1994-96, } \\
\text { 2001-2002 }\end{array}$ & -- & -- & -- \\
\hline Oak Creek at South Milwaukee & OCSM & 04087204 & 25.0 & 1963-2005 & 49 & 7.8 & 1.9 \\
\hline $\begin{array}{l}\text { Root River at Grange Avenue } \\
\text { at Greenfield }\end{array}$ & RRG & 04087214 & 14.7 & 2004-2005 & 31 & 3.8 & .81 \\
\hline Root River near Franklin & $\mathrm{RRF}$ & 04087220 & 49.2 & $1963-2005$ & 92 & 16 & $4.3^{\mathrm{d}}$ \\
\hline Jewel Creek at Muskego & $\mathrm{JCM}$ & 05544371 & 8.16 & 1999-2003 & 12 & 3.8 & 1.5 \\
\hline $\begin{array}{l}{ }^{\text {a }} \text { Automated sample collection at th } \\
\text { b Integrator site. This site receives } \\
\text { Michigan (by way of reverse flow). } \\
{ }^{\mathrm{c}} \text { (Waschbusch and others, 2006) }\end{array}$ & s site. & ukee, Menomone & d Kinnickinnic R & er watersheds in add & on to $w$ & from La & \\
\hline
\end{tabular}


Table 1B. Harbor sites sampled during Phase II of the Milwaukee Metropolitan Sewerage District Corridor Study.

[site locations shown in fig.1]

\begin{tabular}{lcc}
\hline \multicolumn{1}{c}{ Harbor site name } & $\begin{array}{c}\text { Site } \\
\text { abbreviation }\end{array}$ & Site number \\
\hline North Mid-Harbor Milwaukee Outer Harbor Site & OH-04 & 430216087532400 \\
\hline Middle Mid-Harbor Milwaukee Outer Harbor Site & OH-03 & 430134087532900 \\
\hline South Mid-Harbor Milwaukee Outer Harbor Site & OH-11 & 430052087531400 \\
\hline Northern Outside Harbor Breakwall Lake Site & OH-12 & 430240087520300 \\
\hline Middle Outside Harbor Breakwall Lake Site & OH-14 & 430138087514800 \\
\hline Southern Outside Harbor Breakwall Lake Site & OH-13 & 430031087511000 \\
\hline
\end{tabular}

\section{Collection of Stage and Discharge Data}

Stage and discharge data were collected continuously (every 5,15 , or 60 minutes, depending on gage) at 10 of the 15 stream sites at the beginning of Phase II sampling through the USGS stream-gage network (table 1A). One site (Jewel Creek at Muskego) was dropped from the network shortly thereafter. Records from water year 2005 were not published for the Lincoln Creek site; however, the gage remained operational (Waschbusch and others, 2006); data provided for this time period are considered provisional and have been subjected to all quality-control checks and adjustments except those necessary for iceaffected records. Gages at three additional sites were added in April 2004: Honey Creek at Wauwatosa (04087119), Little Menomonee River at Milwaukee (04087070), and Root River at Grange Avenue at Greenfield (04087214). Standard USGS stream-gaging techniques were used to determine discharge at all of the stream gages (Rantz and others, 1982). Current-meter measurements of discharge at the three new sites were made every 4 to 6 weeks and more frequently during high flows to define the stage-discharge relation for each site. Current-meter discharge measurements at the remaining two sites (Willow Creek at Maple Road near Germantown and Jewel Creek at Muskego) were made during water-quality sampling.

\section{Manual Water-Quality Sampling}

Water-quality samples were collected manually at all 15 stream sites and 6 harbor sites (table 1A-B). USGS personnel collected samples at the 14 wadeable stream sites. MMSD personnel collected samples by boat at Milwaukee River at Mouth and the six harbor sites. Water- quality sample-collection protocols differed by the manner of collection. USGS field personnel used standard USGS depth-width-integrated collection methods for wadeable streams; samples were collected from nearby bridges when streams could not be waded because of high flows (U.S. Geological Survey, variously dated). MMSD field personnel collected composite samples from a boat using a Kemmerer sampler deployed at three depths; sampling techniques were modified from standard USGS sampling methods (appendix 2A)(U.S. Geological Survey, variously dated).

Sample collection was designed to encompass a range of flows. From February 2004 through September 2005, personnel from both agencies simultaneously sampled all 21 sites over a few days in an effort to obtain a snapshot of water quality. Samples were collected quarterly over a 2-year period, resulting in eight fixed-interval samples per site. Additionally, personnel collected samples during four targeted high-flow events over the 2-year period: one spring snowmelt event and one summer-storm event per year. Targeted high-flow events for sampling were generally defined as events in which the instantaneous discharge was greater than the 10-percent-flow-duration discharge at gages representing the major basins draining to the harbor (Milwaukee River at Milwaukee, Menomonee River at Wauwatosa, Kinnickinnic River at S. 11th Street at Milwaukee, and Root River near Franklin). Because MMSD sampling boats were not operated during winter months, no samples were collected from the harbor sites during those times; however, samples were collected at Milwaukee River at Mouth (as grab samples) so that all 15 stream sites could be sampled during winter months. Site locations are shown in figure 4. 


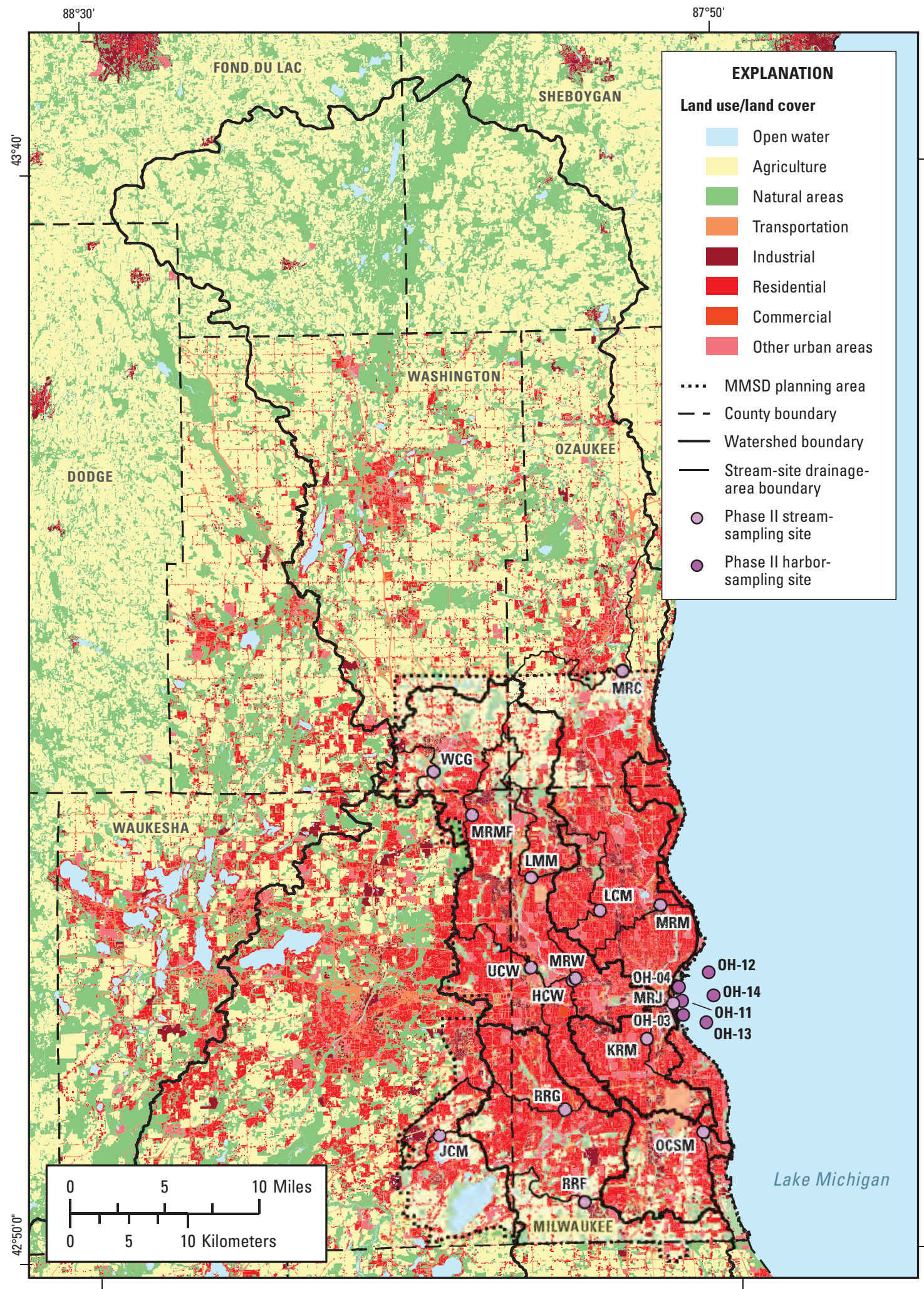

Base composited from Southeastern Wisconsin Regional Planning Commission digital land use inventory, 1:4,800, 2000; Wisconsin Department of Natural Resources WISCLAND land cover, 1:40,000, 1998; Southeastern Wisconsin Regional Planning Commission regional base map, 1:2,000, 1995; U.S. Geological Survey digital line graph hydrography, 1:100,000, 2001; Wisconsin Department of Natural Resources version 2 hydrography, 1:24,000, 2002. Wisconsin Transverse Mercator Projection, referenced to North American Datum of 1983, 1991 adjustment.

Figure 2. Land use/land cover and stream-site drainage-area boundaries for stream sites sampled during Phase II of the Milwaukee Metropolitan Sewerage District (MMSD) Corridor Study. Site abbreviations listed in table 1. 


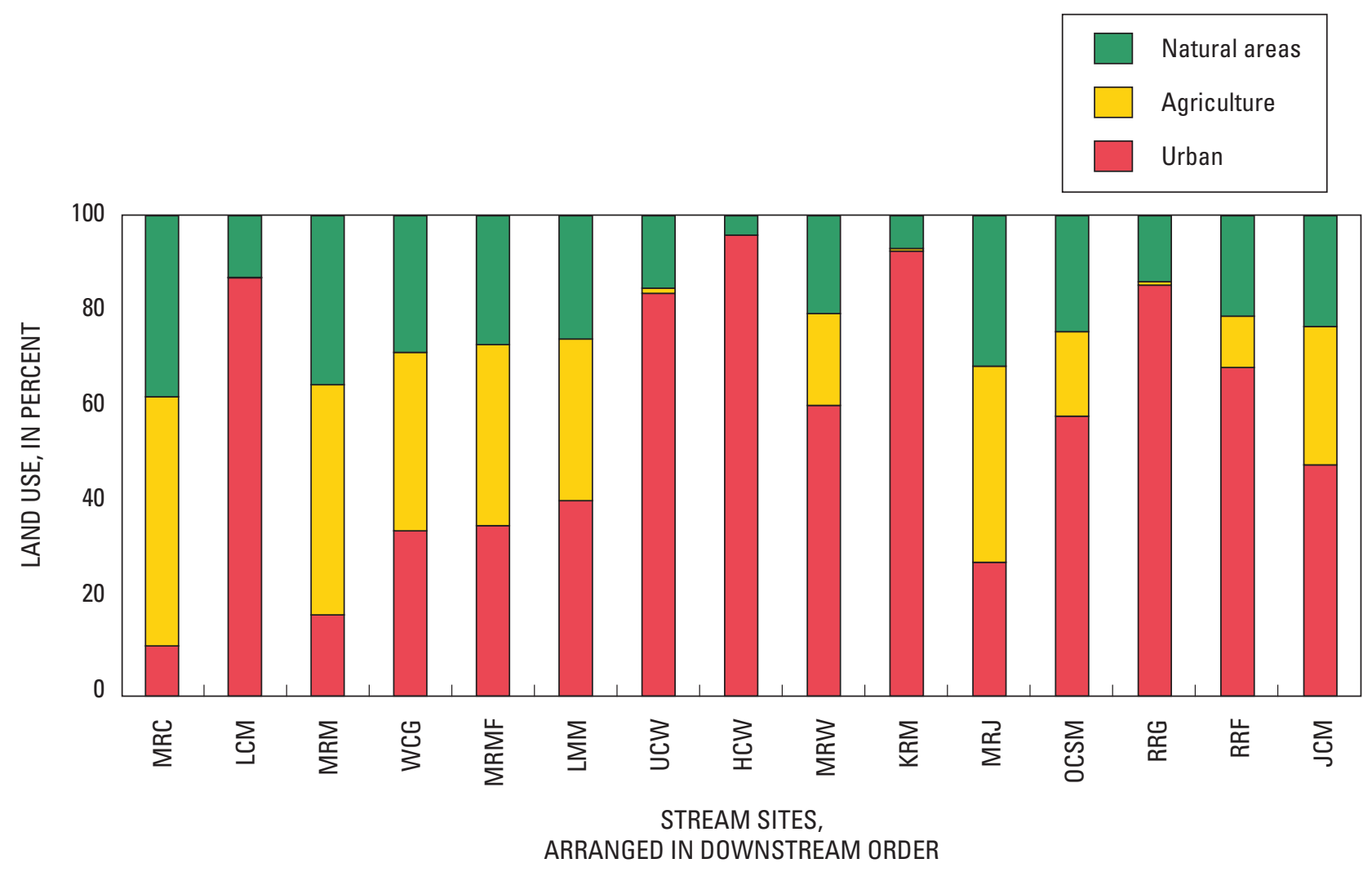

Figure 3. Land use for Phase II sites of the Milwaukee Metropolitan Sewerage District Corridor Study. Urban land use consists of residential, transportation, industrial, commercial, and other urban land use. Site abbreviations listed in table 1. 


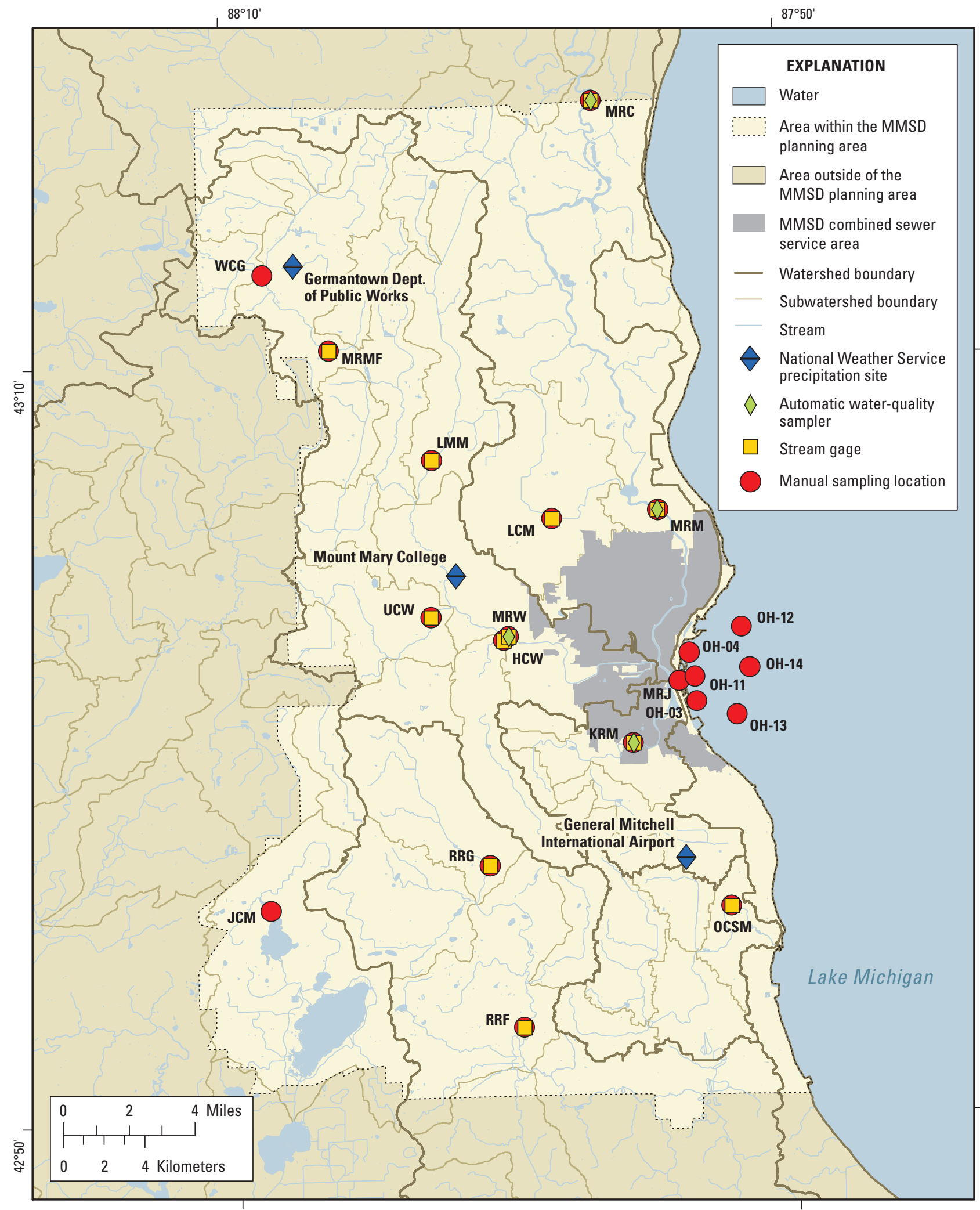

Base composited from Southeastern Wisconsin Regional Planning Commission regional base map, 1:2,000, 1995; U.S. Geological Survey digital line graph hydrography, 1:100,000, 1989; Wisconsin Department of Natural Resources version 2 hydrography, 1:24,000, 2002; sewershed boundaries from Milwaukee Metropolitan Sewerage District 2020 Facilities Plan Sewershed Mapping digital database, 1:2,000, 2005. Wisconsin Transverse Mercator Projection, referenced to North American Datum of 1983, 1991 adjustment.

Figure 4. Locations and characteristics of Phase II sampling sites, and locations of National Weather Service precipitation gages in the Milwaukee Metropolitan Sewerage District (MMSD) planning area, Wis. Site abbreviations listed in table 1. 
Ambient water temperature, $\mathrm{pH}$, specific conductance, and dissolved oxygen were measured at all sites during sampling using a calibrated multiparameter meter. All water samples were brought back to a central processing area (vehicle or laboratory) where samples were processed (split, filtered, and preserved). All water-quality samples were delivered to the appropriate laboratory for analysis. All manually collected water-quality samples were analyzed for a variety of water-quality constituent groups: nutrients, major inorganics, carbon, wastewater compounds (WWCs) and microbes (table 2 and appendix $3)$. The laboratories used for analyses were: USGS laboratories (National Water-Quality Laboratory (NWQL) in Denver, Colo.; Wisconsin Water Science Center Mercury Research Laboratory in Middleton, Wis.; Iowa Water Science Center Sediment Laboratory in Iowa City, Iowa; Kentucky Water Science Center Sediment Laboratory in Louisville, Ky.) and the Wisconsin State Lab of Hygiene (WSLH) in Madison, Wis.

The general timeline for hydrologic, water-quality, and biologic data collection is given in figure 5. Samples were analyzed for most constituents during each sampling event, however, a few constituents were investigated less frequently during selected target conditions. Samples were collected for pesticide and water-column-toxicity analysis from all 21 sites during the spring-quarterly sampling (before pesticides were being actively applied) and during the summer-storm events (fig. 5). Samples for mercury analysis were collected at all sites during the summerquarterly and event sampling.

\section{Mercury Sampling}

Because of the generally low mercury concentrations in natural waters, extra care is required when sampling. To accurately quantify the concentration of total mercury $(\mathrm{Hg})$ and methylmercury $(\mathrm{MeHg})$ in water samples, trace-metal clean techniques were used to minimize sample contamination during collection, handling, and analysis. Analytical methods used for constituent detection were highly sensitive and operated with a reporting level of $0.04 \mathrm{ng} / \mathrm{L}$ for both $\mathrm{Hg}$ and $\mathrm{MeHg}$. A brief description of sampling procedures is in appendix $2 \mathrm{~B}$; a more complete description can be found in Olson and DeWild (1999).

Table 2. List of properties and constituents analyzed during Phase II of the Milwaukee Metropolitan Sewerage District Corridor Study.

[BOD, biochemical oxygen demand; COD, chemical oxygen demand; PCBs, polychlorinated biphenyls]

\begin{tabular}{|c|c|c|}
\hline Property or constituent & Sample frequency & Constituents listed in: \\
\hline $\begin{array}{l}\text { Automatically collected samples (chloride, } \\
\text { total phosphorus, and suspended sediment) }\end{array}$ & Quarterly, events, automated samples & Appendix 3 , table $3-1$ \\
\hline $\begin{array}{l}\text { Field parameters (alkalinity, dissolved oxygen, } \mathrm{pH} \text {, } \\
\text { specific conductance, temperature) }\end{array}$ & Quarterly, events & Appendix 3, table 3-2 \\
\hline Carbon (dissolved and particulate) and particulate nitrogen & Quarterly, events & Appendix 3 , table $3-3$ \\
\hline $\begin{array}{l}\text { Miscellaneous water-quality measurements (chlorophyll } a \text {, } \\
\text { BOD, COD, pH, specific conductance, suspended } \\
\text { sediment }\end{array}$ & Quarterly, events & Appendix 3, table 3-4 \\
\hline Water-column toxicity testing & Summer 2004 and 2005 & Appendix 3, table $3-4$ \\
\hline Major inorganics & Quarterly, events & Appendix 3 , table $3-5$ \\
\hline Nutrients & Quarterly, events & Appendix 3, table 3-6 \\
\hline Total mercury and methylmercury & 1 quarterly, 1 summer event & Appendix 3 , table $3-7$ \\
\hline Indicator and pathogenic microorganisms & Quarterly, events & Appendix 3 , table $3-8$ \\
\hline Pesticides and degradates & 1 quarterly, 1 summer event & Appendix 3, table 3-9 \\
\hline Wastewater compounds & Quarterly, events & Appendix 3, table 3-10 \\
\hline SPMD extracts analyses & Single 1-month sample in 2004 & Appendix 3, table 3-11 \\
\hline Total PCBs, metals, and organic carbon in sediment & Summer 2004 and 2005 & Appendix 3, table 3-12 \\
\hline Fish tissue analyses (including pesticides and PCBs) & October 2004 & Appendix 3, table 3-13 \\
\hline Bioassessment (fish, macroinvertebrates, algae, and habitat) & Summer and autumn, 2004 & Appendix 3, table 3-14 \\
\hline
\end{tabular}




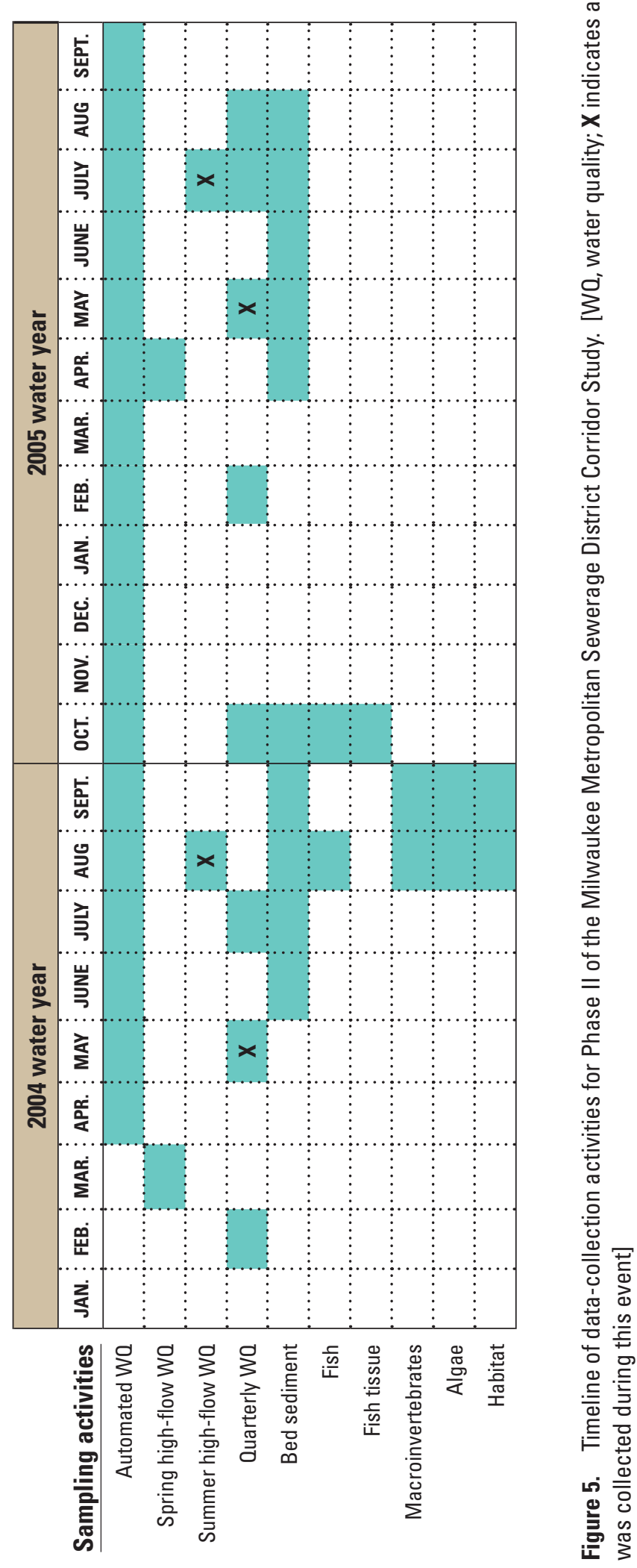




\section{Microbiological Sampling}

Samples for microbiological analysis were collected at each of the 21 sites during every sample visit and were analyzed by WSLH. WSLH holding times (for monitoring purposes) for fecal coliform and Escherichia coli (E. coli) were 24 hours; the microbiological samples $(14 \mathrm{~L})$ were transported to the WSLH on the day they were collected in order to adhere to this holding time. For 10 of the 12 sampling events, samples were also collected for analysis by MMSD. These samples $(500 \mathrm{~mL})$ were collected and delivered to MMSD in compliance with Wisconsin Administrative Code NR 219, which specifies that analyses for fecal coliform and $E$. coli must be analyzed within 6 hours of sample collection. Sample results from the two laboratories were compared to determine the degree of variability and the absolute difference between concentrations reported.

The WSLH data set was used for analyses of fecal coliform and $E$. coli in this report since all sampling events were represented and all other microbiological constituents were analyzed by this laboratory.

\section{Bed-Sediment Sampling}

Streambed-sediment traps were used in Phase II as a means to qualitatively assess the current transport rates of metals and polychlorinated biphenyl (PCBs) in specific stream segments. Bed-sediment analyses for metals and
PCBs were less expensive than equivalent tests on watercolumn samples; moreover, because many metals and organic chemicals sorb onto fine sediment particles, bedsediment analyses were an effective means of integrating contamination episodes in stream segments over extended time periods. Sediment-trap samples were analyzed for total PCBs, total phosphorus, particle grain size, arsenic, cadmium, chromium, copper, lead, mercury, nickel, and zinc. Sediment traps were deployed at each of the 15 stream-sampling locations. Two traps were deployed at each site during the 2004 and 2005 field seasons (approximately June-October 2004 and approximately AprilAugust 2005). During each field season, sediment traps were deployed for periods ranging from 1 to 4 months.

These sediment traps were based on designs used by WDNR at Lincoln Creek (Baird and Associates, 1997). The traps were made from concrete blocks, plywood, PVC pipe, and acrylic plastic sheet stock (fig. 6). The traps primarily served to anchor and protect the glass jars used to collect the sediment samples. The jars used in the sediment traps were rinsed with acetone before deployment at the sample sites.

If an insufficient sediment volume was collected at a site by the time of the midseason sample collection, the sediment that was collected was bottled and stored at $4^{\circ} \mathrm{C}$, and the sediment trap was cleaned and redeployed. At the end of the season, the stored sample and the end-of-season sample were combined and submitted for analysis.

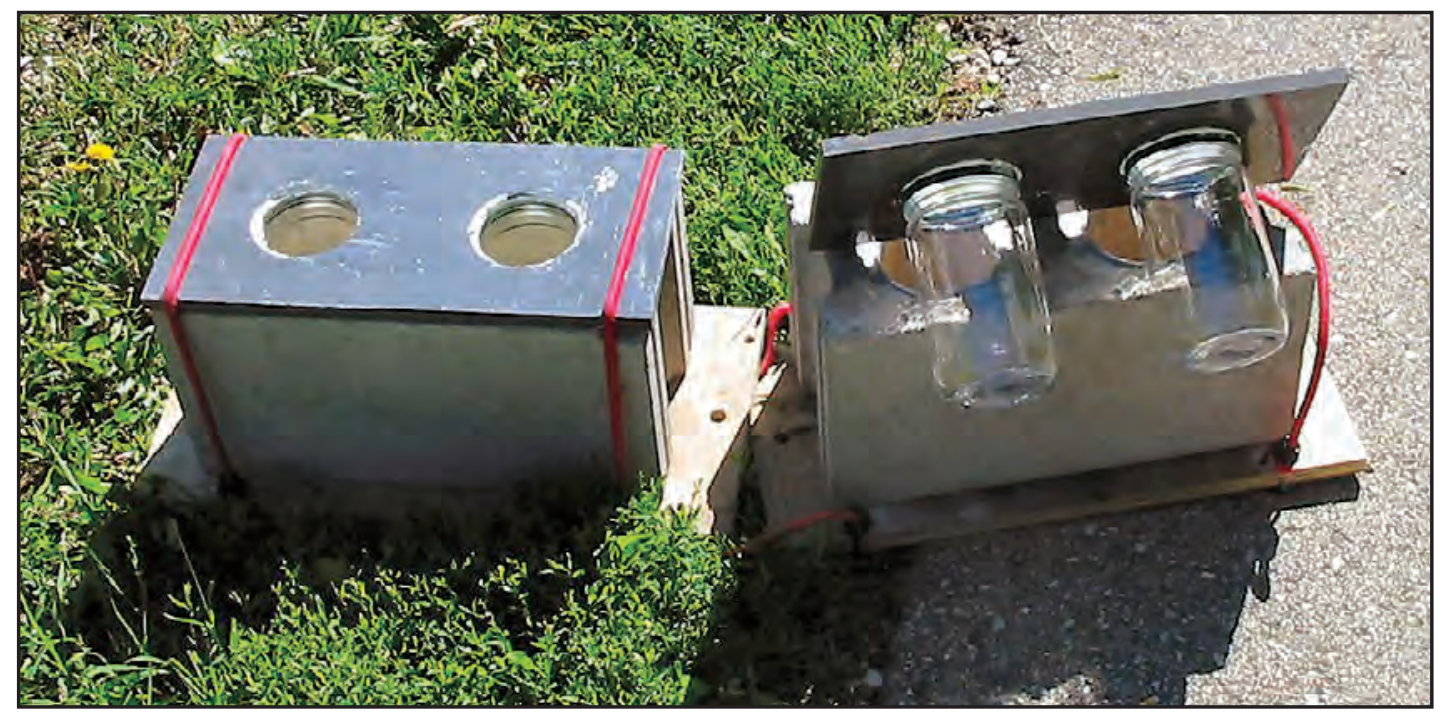

Figure 6. Sediment traps used for collection of bed-sediment samples during Phase II of the Milwaukee Metropolitan Sewerage District Corridor Study. 


\section{Water-Column-Toxicity Sampling}

Acute toxicity of water-column samples was analyzed by WSLH using the Microtox Acute Toxicity Test (Strategic Diagnostics Inc., Newark, Del.). This analysis quantifies differences (expressed in percent effect) in the fluorescence values of bioluminescent marine bacteria exposed to sample water when compared to a laboratory control. Decreases in fluorescence (positive percent effect values) are attributed to the toxic effects of sample water on the viability of test bacteria; the magnitude of the change in luminescence relates positively to the toxicity of the sample water. Changes in luminescence were reported after 5 minutes and 15 minutes of exposure to environmental sample water (AZUR Environmental, 1998). Samples submitted for toxicity analysis were collected from all 21 Phase II sampling sites during summer-quarterly and event sampling.

\section{Biological, Habitat Assessment, and Fish- Tissue Toxicity Sampling}

One-time surveys were conducted in late summer and early autumn 2004 for fish-, macroinvertebrate-, and algal-community data, as well as habitat data at the 14 wadeable stream sites that were sampled as part of Phase II (table 1A). Fish, macroinvertebrates, and algae samples were collected according to the methods documented in Moulton and others (2002): fish-fish sampling protocols; algae-qualitative multi-habitat sampling protocols; macroinvertebrates-semi-quantitative targeted habitatsampling protocols. Fish were collected, identified, and enumerated in the field. Fish-tissue samples were collected during fish-community surveys and analyzed for accumulated toxics (metals and PCBs) at three sites (Milwaukee

River at Milwaukee, Menomonee River at Wauwatosa, and Root River near Franklin). Identification and enumeration of macroinvertebrate samples was done by the University of Wisconsin-Stevens Point Aquatic Entomology Laboratory, except for samples from the Little Menomonee River and Honey Creek sites, which were done by the USGS National Water-Quality Laboratory. Algae samples were identified and enumerated by the Academy of Natural Sciences in Philadelphia, Pa. Habitat assessments were performed using methods employed by the NAWQA program, as documented in Fitzpatrick and others (1998).
Semipermeable Membrane Device Sampling from the National Water-Quality Assessment Program

Semipermeable membrane devices (SPMDs) mimic biological membranes, such as the gills of fish, and can be used to predict contaminant exposure and accumulation in fish. These devices contain a synthetic lipid solution similar to that found in fish. SPMDs are used to gather time-integrated information on the presence of dissolved (biologically available) hydrophobic organic contaminants in water. Toxicity tests followed by chemical analyses were done on extracts from the triolein in the SPMDs. The Cytochrome P450RGS test assessed toxicity from PAHs, planar PCBs, dioxins, and furans in the water. The Fluoroscan test estimated the concentration of PAH compounds and was expressed in pyrene equivalents, and the Microtox test screened for acute toxicity from synthetic organic compounds.

As part of the USGS NAWQA Effects of Urbanization on Stream Ecosystems Topical Study in 2004, SPMDs were deployed at 30 sites in the Western Lake Michigan Drainages study unit. SPMDs were placed for one month at 15 Milwaukee-area sites, 7 of which were at or within a few miles of MMSD sample sites on these streams. Four NAWQA sites were at the same location as Phase II sites (Lincoln Creek, Oak Creek, Menomonee River at Menomonee Falls, and Little Menomonee River), and three NAWQA sites were near MMSD sites: Honey Creek near Portland Avenue at Wauwatosa (04087118, about 1 mi upstream from the Honey Creek at Wauwatosa Phase II site), Root River at Layton Avenue at Greenfield (04087213, about 2 mi upstream from the Root River at Grange Avenue Phase II site), and Underwood Creek at Watertown Plank Road at Elm Grove (040870856, about 3 mi upstream of the Underwood Creek at Wauwatosa Phase II site).

Toxicity tests were done by the U.S. Army Corps of Engineers in Vicksburg, Miss. (P450RGS test) and the USGS Columbia Environmental Research Center in Columbia, Mo. (Fluoroscan and Microtox tests). Chemical analyses of the SPMD extracts were done at the USGS National Water-Quality Laboratory in Denver, Colo. 


\section{Automated Water-Quality Sampling}

Automated samplers were installed and maintained by USGS personnel and used to collect water-quality samples so that loads of suspended sediment, total phosphorus, and chloride could be computed. The four sites where the samplers were installed were Milwaukee River near Cedarburg (04086600), Milwaukee River at Milwaukee (04087000), Kinnickinnic River at South 11th Street at Milwaukee (04087159), and Menomonee River at Wauwatosa (04087120).

Approximately 8 to 10 samples were collected per storm. More samples were collected during times of increasing discharge, when the constituent concentrations were expected to have the greatest variation. Samples were analyzed for suspended sediment, total phosphorus, and chloride by the Wisconsin State Laboratory of Hygiene (WSLH). Storm, daily, and annual loads were computed for each site. Constituent loads were determined by multiplying constituent concentration by stream discharge and a conversion factor (Porterfield, 1972). Daily loads were determined by use of the integration method described by Porterfield (1972). Daily and annual loads were compared to historical data at these sites.

\section{Quality Assurance and Quality Control}

Quality-assurance and quality-control (QA/QC) samples collected during Phase II of the MMSD Corridor Study made up about 15 percent of the water-quality samples. QA/QC samples included both field blanks and replicates. Field-blank results were evaluated to estimate how analytical results might be biased by contamination of the sample from the sampling equipment, equipment cleaning, and sample processing. Replicate samples were evaluated to estimate the degree of variability in sample results. Results from the blanks are summarized in table 3, and replicate results are summarized in table 4.

Field blanks were collected by passing certified, analyte-free blank water through the cleaned sampling apparatus. Field-blank results where constituent concentrations were less than 25 percent of the minimum environmental sample concentration were determined to be within data-quality limits, and were considered insignificant with respect to result interpretation (MacCoy, 2004). Fieldblank results where constituent concentrations exceeded 25 percent of the minimum environmental sample concentration were examined further to determine how contamination affected data interpretation. Some constituents were detected but not quantified in field blanks; detections of this type also are noted in table 3 .

For most constituents, blank detections were found to be within data-quality limits (table 3). However, concentrations in blanks exceeded 25 percent of the minimum environmental sample concentration for silica (15 of 17 field blanks), biochemical oxygen demand (BOD) (10 of 17 field blanks), chlorophyll $a$ ( 3 of 17 field blanks), and chemical oxygen demand (COD) (13 of 17 field blanks). Equipment-cleaning solutions may have been responsible for the high number of detections of BOD and COD in field blanks. Laboratory variability may have been responsible for the blank detections in chlorophyll $a$ (a point that will be further illustrated in the sample-replicate result discussion).

Analysis of wastewater compounds (WWCs) involved new techniques whose methods for detection are challenged by issues of contamination and low reporting levels. Due to the small number of samples with concentrations above the reporting level, percent detections were used to discuss their occurrence. Phenol was detected in 9 of 17 field blanks as well as NWQL laboratory blanks; therefore, it was dropped entirely from analysis. N,Ndiethyl-meta-toluamide (DEET) was not detected in NWQL laboratory blanks but was detected in field blanks. The majority of DEET field-blank contamination was at a level that could only be qualitatively detected; since this type of sample data were considered nondetections for the purposes of analyses, the impact of the contamination on the results discussed in this report was felt to be negligible (table 18, page 83). Any constituent result that was detected but not quantified was counted as a non-detect for the purposes of data analysis. DEET field-blank contamination was not fully understood, but may have been due to an atmospheric source, a proximity to field gear/sampling equipment containing residual insect repellent, or some other undetermined source (Kingsbury and others, 2006). NWQL laboratory blank results also indicated contamination of naphthalene and 1-methylnapthalene. With respect to field blanks, it is likely that phenol, naphthalene and 1-methylnapthalene contamination were also affected by the proximity of sample processing in or near gasolinepowered vehicles. 
Table 3. Results of constituent detections in field blanks during Phase II of the Milwaukee Metropolitan Sewerage District (MMSD) Corridor Study.

[mg/L, milligram per liter; $\mu \mathrm{g} / \mathrm{L}$, microgram per liter; e, estimated; M, detected but not quantified]

\begin{tabular}{|c|c|c|c|c|c|c|c|}
\hline Constituent & $\begin{array}{l}\text { Reporting } \\
\text { level }\end{array}$ & $\begin{array}{l}\text { Total } \\
\text { number of } \\
\text { samples }\end{array}$ & $\begin{array}{c}\text { Number } \\
\text { of } \\
\text { blanks }\end{array}$ & $\begin{array}{l}\text { Percent total } \\
\text { quality-control } \\
\text { samples }\end{array}$ & $\begin{array}{l}\text { Number of } \\
\text { detections in } \\
\text { field blanks }\end{array}$ & $\begin{array}{c}\text { Range of } \\
\text { detections in } \\
\text { field blanks }\end{array}$ & $\begin{array}{l}\text { Within } \\
\text { data-quality } \\
\text { limits }^{1}\end{array}$ \\
\hline \multicolumn{8}{|c|}{ Miscellaneous constituents } \\
\hline $\begin{array}{l}\text { Carbon (inorganic plus } \\
\text { organic), suspended } \\
\text { sediment, total }\end{array}$ & $0.12 \mathrm{mg} / \mathrm{L}$ & 235 & 15 & 6 & 1 & 0.1 & Yes \\
\hline Organic carbon, water, filtered & $.33 \mathrm{mg} / \mathrm{L}$ & 235 & 15 & 6 & 11 & $\mathrm{e} 0.2-0.7$ & Yes \\
\hline $\begin{array}{l}\text { Particulate nitrogen, suspended } \\
\text { in water }\end{array}$ & $.022 \mathrm{mg} / \mathrm{L}$ & 235 & 15 & 6 & 2 & $0.02-0.03$ & Yes \\
\hline Calcium, water, filtered & $.010 \mathrm{mg} / \mathrm{L}$ & 235 & 17 & 7 & 17 & $0.01-0.24$ & Yes \\
\hline Silica, water, filtered & $.04 \mathrm{mg} / \mathrm{L}$ & 235 & 17 & 7 & 15 & $\mathrm{e} 0.03-3.04$ & No \\
\hline Sodium, water, filtered & $.10 \mathrm{mg} / \mathrm{L}$ & 235 & 17 & 7 & 12 & $\mathrm{e} 0.05-0.49$ & Yes \\
\hline Chloride, water, filtered & $.20 \mathrm{mg} / \mathrm{L}$ & 235 & 17 & 7 & 6 & $\mathrm{e} 0.15-1.23$ & Yes \\
\hline Magnesium, water, filtered & $.008 \mathrm{mg} / \mathrm{L}$ & 235 & 17 & 7 & 10 & $\mathrm{e} 0.004-0.011$ & Yes \\
\hline Iron, water, filtered & $6.4 \mu \mathrm{g} / \mathrm{L}$ & 235 & 17 & 7 & 1 & e5 & Yes \\
\hline $\begin{array}{l}\text { Total nitrogen (nitrate }+ \\
\text { nitrite }+ \text { ammonia }+ \text { organic } \\
\text { nitrogen), water, unfiltered, } \\
\text { analytically determined }\end{array}$ & $.03 \mathrm{mg} / \mathrm{L}$ & 235 & 17 & 7 & 1 & 0.03 & Yes \\
\hline $\begin{array}{l}\text { Biochemical oxygen demand, } \\
\text { water, unfiltered, } 5 \text { days at } \\
20 \text { degrees Celsius }\end{array}$ & $2 \mathrm{mg} / \mathrm{L}$ & 235 & 17 & 7 & 10 & $2.1->22.5$ & No \\
\hline $\begin{array}{l}\text { Chlorophyll } a \text {, water, } \\
\text { unfiltered, trichromatic } \\
\text { method, uncorrected }\end{array}$ & $.26 \mu \mathrm{g} / \mathrm{L}$ & 235 & 17 & 7 & 3 & $6.59-9.07$ & No \\
\hline $\begin{array}{l}\text { Chemical oxygen demand, } \\
\text { low level, water, unfiltered }\end{array}$ & $9 \mathrm{mg} / \mathrm{L}$ & 235 & 17 & 7 & 13 & $11-260$ & No \\
\hline
\end{tabular}


Table 3. Results of constituent detections in field blanks during Phase II of the Milwaukee Metropolitan Sewerage District (MMSD) Corridor Study-Continued.

[mg/L, milligram per liter; $\mu \mathrm{g} / \mathrm{L}$, microgram per liter; e, estimated; $\mathrm{M}$, detected but not quantified]

\begin{tabular}{|c|c|c|c|c|c|c|c|}
\hline Constituent & $\begin{array}{l}\text { Reporting } \\
\text { level }\end{array}$ & $\begin{array}{c}\text { Total } \\
\text { number of } \\
\text { samples }\end{array}$ & $\begin{array}{c}\text { Number } \\
\text { of } \\
\text { blanks }\end{array}$ & $\begin{array}{l}\text { Percent total } \\
\text { quality-control } \\
\text { samples }\end{array}$ & $\begin{array}{l}\text { Number of } \\
\text { detections in } \\
\text { field blanks }\end{array}$ & $\begin{array}{c}\text { Range of } \\
\text { detections in } \\
\text { field blanks }\end{array}$ & $\begin{array}{c}\text { Within } \\
\text { data-quality } \\
\text { limits }^{1}\end{array}$ \\
\hline \multicolumn{8}{|c|}{ Wastewater compounds } \\
\hline Menthol & $0.5 \mu \mathrm{g} / \mathrm{L}$ & 235 & 17 & 7 & 1 & M & Yes \\
\hline Methyl salicylate & $.5 \mu \mathrm{g} / \mathrm{L}$ & 235 & 17 & 7 & 1 & M & Yes \\
\hline Tributyl phosphate & $.5 \mathrm{ug} / \mathrm{L}$ & 235 & 17 & 7 & 1 & M & Yes \\
\hline Triphenyl phosphate & $.5 \mu \mathrm{g} / \mathrm{L}$ & 235 & 17 & 7 & 1 & M & Yes \\
\hline 1,4-Dichlorobenzene & $.5 \mu \mathrm{g} / \mathrm{L}$ & 235 & 17 & 7 & 1 & 0.2 & Yes \\
\hline $\begin{array}{l}d \text {-Limonene, water, filtered, } \\
\text { recoverable, } \mu \mathrm{g} / \mathrm{L}\end{array}$ & $.5 \mu \mathrm{g} / \mathrm{L}$ & 235 & 17 & 7 & 1 & 0.1 & Yes \\
\hline Tris(2-chloroethyl) phosphate & $.5 \mu \mathrm{g} / \mathrm{L}$ & 235 & 17 & 7 & 1 & 0.1 & Yes \\
\hline Isophorone & $.5 \mu \mathrm{g} / \mathrm{L}$ & 235 & 17 & 7 & 2 & $\mathrm{M}-0.1$ & Yes \\
\hline Acetophenone & $.5 \mu \mathrm{g} / \mathrm{L}$ & 235 & 17 & 7 & 2 & $0.1-0.2$ & Yes \\
\hline Tetrachloroethylene & $.5 \mu \mathrm{g} / \mathrm{L}$ & 235 & 17 & 7 & 3 & M & Yes \\
\hline Camphor & $.5 \mu \mathrm{g} / \mathrm{L}$ & 235 & 17 & 7 & 3 & M & Yes \\
\hline Fluoranthene & $.5 \mu \mathrm{g} / \mathrm{L}$ & 235 & 17 & 7 & 5 & $\mathrm{M}$ & Yes \\
\hline Pyrene & $.5 \mu \mathrm{g} / \mathrm{L}$ & 235 & 17 & 7 & 5 & $\mathrm{M}-0.1$ & Yes \\
\hline 1-Methylnaphthalene & $.5 \mu \mathrm{g} / \mathrm{L}$ & 235 & 17 & 7 & 5 & $\mathrm{M}-0.1$ & Yes \\
\hline Phenanthrene & $.5 \mu \mathrm{g} / \mathrm{L}$ & 235 & 17 & 7 & 6 & M & Yes \\
\hline Benzophenone & $.5 \mu \mathrm{g} / \mathrm{L}$ & 235 & 17 & 7 & 6 & $\mathrm{M}-0.1$ & Yes \\
\hline 2-Methylnaphthalene & $.5 \mu \mathrm{g} / \mathrm{L}$ & 235 & 17 & 7 & 7 & $\mathrm{M}-0.3$ & Yes \\
\hline $\begin{array}{l}\text { N,N-diethyl-meta-toluamide } \\
\quad \text { (DEET) }\end{array}$ & $.5 \mu \mathrm{g} / \mathrm{L}$ & 235 & 17 & 7 & 9 & M-0.1 & Yes \\
\hline Naphthalene & $.5 \mu \mathrm{g} / \mathrm{L}$ & 235 & 16 & 7 & 10 & $\mathrm{M}-0.1$ & Yes \\
\hline Phenol & $.5 \mu \mathrm{g} / \mathrm{L}$ & 235 & 14 & 6 & 11 & $0.2-0.5$ & No \\
\hline
\end{tabular}

${ }^{1}$ Field-blank results where constituent concentrations were less than 25 percent of the minimum environmental sample concentration were determined to be within data-quality limits, and were considered insignificant with respect to result interpretation (MacCoy, 2004). 


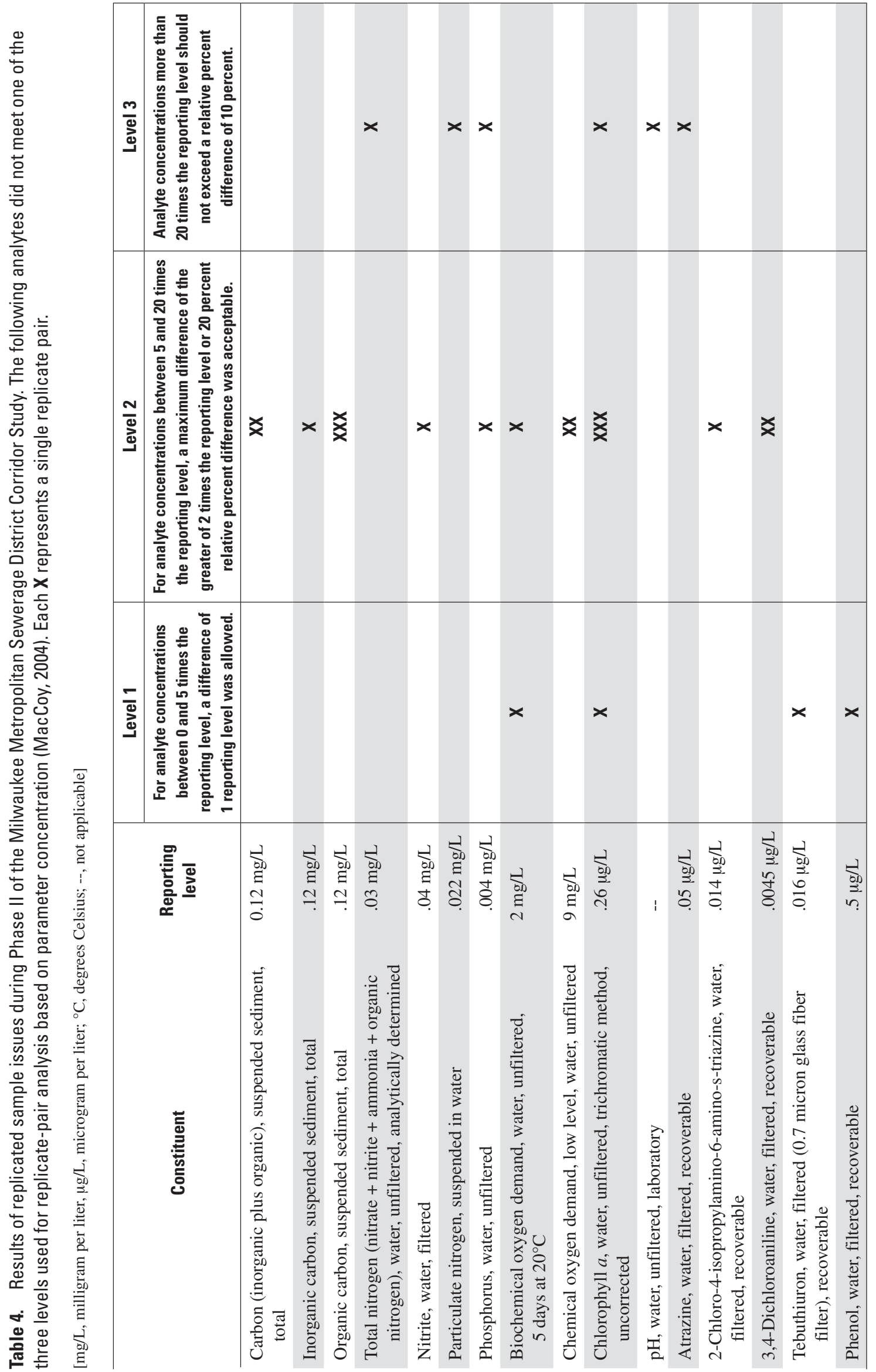


Of the constituents analyzed during Phase II, the majority of replicate-constituent results were within the quality-control limits. As a mathematical rule, relative percent differences (RPDs) between 2 small numbers are higher than the RPD between 2 larger numbers with the same value difference; in order to adjust for that phenomenon, replicate samples were evaluated at 3 levels based on the concentration of the analyte above the reporting level (MacCoy, 2004). Level 1 evaluation was defined for constituents whose concentration was between 0 and 5 times the reporting level, in which case a difference of 1 reporting level was allowed between replicate pairs. Level 2 evaluation was defined for constituents with detection between 5 and 20 times the reporting level. In this case, a maximum difference of the greater of 2 times the reporting level or 20 percent RPD was allowed. Level 3 evaluation was defined for constituents with concentrations more than 20 times the reporting level. Constituents at this level were not to exceed an RPD of 10 percent. Replicate pairs where 1 result was above and 1 result was below the reporting level were not considered where the higher result was within a reporting level difference of the reporting level; BOD and particulate inorganic carbon each contained a single replicate pair showing a difference greater than one reporting level. Very few replicate-pair results failed to meet quality-control limits (table 4). More than 1 sample pair for each of the following constituents exceeded quality-control limits: chlorophyll a (5 sample pairs), particulate organic carbon (3 sample pairs), particulate total carbon (2 sample pairs), phosphorus (2 sample pairs), BOD (2 sample pairs), COD (2 sample pairs), and 3,4 Dichloroaniline (2 sample pairs). One sample pair for each of the following constituents exceeded quality-control limits: particulate inorganic carbon, total nitrogen, particulate nitrogen, nitrate, $\mathrm{pH}$, atrazine, 2-Cholor-4-isopropylamino6-amino-s-triazine, tebuthiuron, and phenol.

\section{Special Cases of Quality Control for Selected Constituents}

Due to the unique nature of the data, quality-control analyses of microbiological, bed sediment, and watercolumn toxicity were not subject to the same types of analyses as other water chemistry constituents.

\section{Microbiological}

Quality-control (QC) results for microbiological samples are known to have higher levels of variability than those for chemical-quality constituents. Analytical methods used for quantification of indicator and pathogenic microorganisms differed in strategy. Methods for indicator organisms generally analyzed sample volumes similar to what was reported for the result and generated data sets of continuous values. Methods for pathogenic organisms generally analyzed sample volumes that were quite different from the reported volume, and when the number of organisms detected were adjusted to the reported volume, it generated data sets of discrete values with many concentrations in partial organisms (for example, 33.3 oocysts/100 L). As a result of the difference in these data sets, QC analyses for indicator organisms and pathogenic organisms were evaluated separately.

Replicate-pair comparisons for indicator organisms were analyzed in much the same manner as other water-quality constituents; results were divided into three levels based on the concentration of the analyte above the reporting level (MacCoy, 2004). Replicate-pair analyses performed by WSLH are summarized in table 5, along with the criteria used for water-quality replicate-pair evaluation. However, given that microbiological samples are known to have higher variability than most water-quality constituents, data were not evaluated for violations of replicate criteria associated with each level. Variability was generally low to moderate for indicator organisms, with a few exceptions in the data sets for each indicator organism. The most notable difference was a non-matching replicate pair in the fecal coliform data set, where members of the replicate pair had concentrations of less than 10 and $200 \mathrm{col} / 100 \mathrm{~mL}$. In addition, one of the replicate pairs in Level 3 of this data set differed by an RPD of 125 percent. Replicate pairs with the highest RPDs in the E. coli and coliphage data sets represented relatively small differences in actual concentrations. 


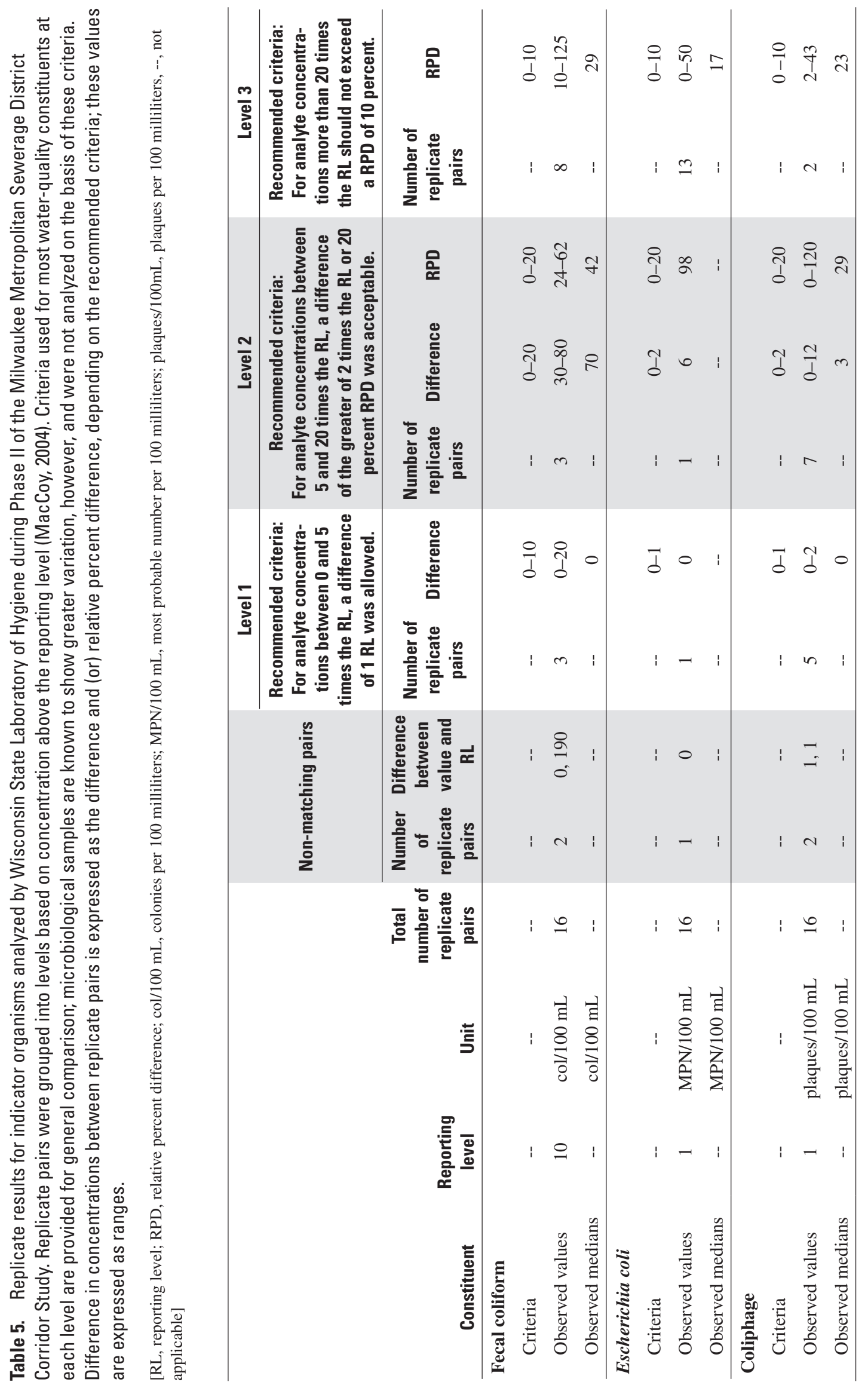


Fecal coliform and E. coli analyses were also performed by MMSD and replicate analyses for these samples generally indicated slightly less variability when compared to the WSLH data sets. All replicate pairs for MMSD fecal coliform and E. coli analyses (9 and 10, respectively) grouped into Level 3 and indicated RPDs of 9 to $59 \mathrm{col} / 100 \mathrm{~mL}$ (median of $30 \mathrm{col} / 100 \mathrm{~mL}$ ) and 0 to 32 most probable number per 100 milliliters (MPN/100 $\mathrm{mL}$ )(median of $11 \mathrm{MPN} / 100 \mathrm{~mL}$ ).

In addition to QC analysis of traditional replicate-pairs analyzed by each laboratory, analyses were performed on results for all (regular and QC) samples analyzed by both laboratories to determine the degree of variability and the absolute difference between results reported. Comparison of fecal coliform and E. coli results from WSLH and MMSD are illustrated in figure 7. Slightly more variability was observed among fecal coliform results ( $\mathrm{R}^{2}$ value of 0.71$)$, than among $E$. coli results $\left(\mathrm{R}^{2}\right.$ value of 0.91$)$. With relation to absolute difference, a line of one-to-one correspondence on these graphs would indicate that results reported by these laboratories were identical for concurrently-collected samples. The distribution of fecal coliform results for this comparison indicates that the body of data lies below the line of one-to-one correspondence, indicating that WSLH concentrations were, on average, lower than MMSD concentrations. The differences in concentrations may have been due to the variation in holding times between the two laboratories. More specifically, the longer holding times at the WSLH may have caused a loss of viability of the microorganisms, thereby causing these concentrations to be consistently lower than MMSD concentrations for fecal coliform. The distribution of $E$. coli results indicated that, on average, the two laboratories found very similar concentrations. In order to maintain consistency within the rest of the microbiological data set, analyses for fecal coliform and E. coli are limited to analytical results from WSLH.

The discrete nature of the results in the pathogen data set required a different approach for replicate analyses; replicate pairs were compared in a manner reflective of analytical and reporting methods. E. coli O157:H7 data were reported as presence/absence; of the 16 replicate pairs analyzed, 1 replicate pair had mismatched results. Results reported for Salmonella were an interpretation of the minimum volume of sample that indicated the presence of the bacterium. Data were limited to values of 0.1 , $0.2,1$, and $10 \mathrm{MPN} / 100 \mathrm{~mL}$, and are reflective of positive results at analytical volumes of 10, 20, 100, and 1,000 $\mathrm{mL}$, respectively. Of the 16 replicate pairs analyzed, 12 replicate pairs had identical results. In 3 of the remaining pairs, 1 member was not detected and the other member was detected in volumes ranging from 10 to $100 \mathrm{~mL}$. Volumes of detection for the final pair were $10 \mathrm{~mL}$ and 100 $\mathrm{mL}$. Giardia and Cryptosporidium replicate analyses were performed using 1.5 to $3.3 \mathrm{~L}$ of sample water; volumes were similar within each replicate pair. The numbers of detections in the analytical volume were extrapolated to the reporting volume of $100 \mathrm{~L}$, and yielded discrete numbers of organisms based on the original sample volume. Replicate comparisons were performed based on differences in individual organism counts in the analytical volume (table 6). Differences were lower for Giardia than

Table 6. Replicate results for pathogenic organisms during Phase II of the Milwaukee Metropolitan Sewerage District Corridor Study. Differences between replicate pairs are expressed as the difference between the actual numbers of organisms counted in the analyzed sample volume.

[RL, reporting level; MPN/100 mL, most probable number per 100 milliliters; cysts/100 mL, cysts per 100 milliliters; oocysts/100 mL, oocysts per 100 milliliters; --, not applicable]

\begin{tabular}{|c|c|c|c|c|c|c|c|c|}
\hline \multirow[b]{2}{*}{ Constituent } & \multirow[b]{2}{*}{$\begin{array}{c}\text { Volumes } \\
\text { analyzed for } \\
\text { replicate pairs }\end{array}$} & \multirow[b]{2}{*}{$\begin{array}{l}\text { RLs for } \\
\text { replicate } \\
\text { pairs }\end{array}$} & \multirow[b]{2}{*}{$\begin{array}{l}\text { Reporting } \\
\text { level unit }\end{array}$} & \multirow{2}{*}{$\begin{array}{l}\text { Total } \\
\text { number of } \\
\text { replicate } \\
\text { pairs }\end{array}$} & \multicolumn{4}{|c|}{ Number of replicate pairs } \\
\hline & & & & & $\begin{array}{c}\text { Difference } \\
\text { of zero } \\
\text { organisms }\end{array}$ & $\begin{array}{l}\text { Difference } \\
\text { of one } \\
\text { organism }\end{array}$ & $\begin{array}{l}\text { Difference } \\
\text { of two } \\
\text { organisms }\end{array}$ & $\begin{array}{c}\text { Difference } \\
\text { of three } \\
\text { organisms }\end{array}$ \\
\hline \multicolumn{9}{|l|}{ Giardia } \\
\hline Observed values & $1.5-3.3 \mathrm{~L}$ & $30.3-66.7$ & cysts/100 L & 16 & 15 & 1 & 0 & 0 \\
\hline Observed medians & $3 \mathrm{~L}$ & 33.3 & cysts/100 L & -- & -- & -- & -- & -- \\
\hline \multicolumn{9}{|l|}{ Cryptosporidium } \\
\hline Observed values & $1.5-3.3 \mathrm{~L}$ & $30.3-66.7$ & oocysts/100 L & 16 & 8 & 5 & 2 & 1 \\
\hline Observed medians & $3 \mathrm{~L}$ & 33.3 & oocysts/100 L & -- & -- & -- & -- & -- \\
\hline
\end{tabular}


A

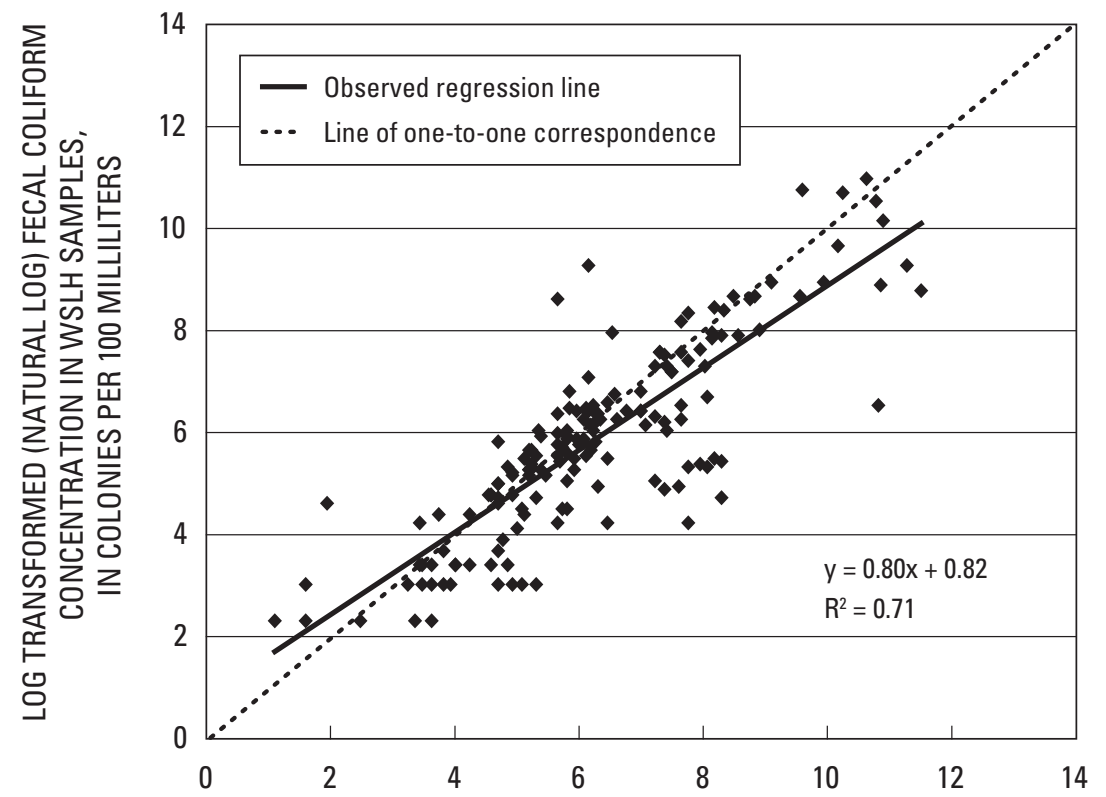

LOG TRANSFORMED (NATURAL LOG) FECAL COLIFORM CONCENTRATION IN MMSD SAMPLES, IN COLONIES PER 100 MILLILITERS

B

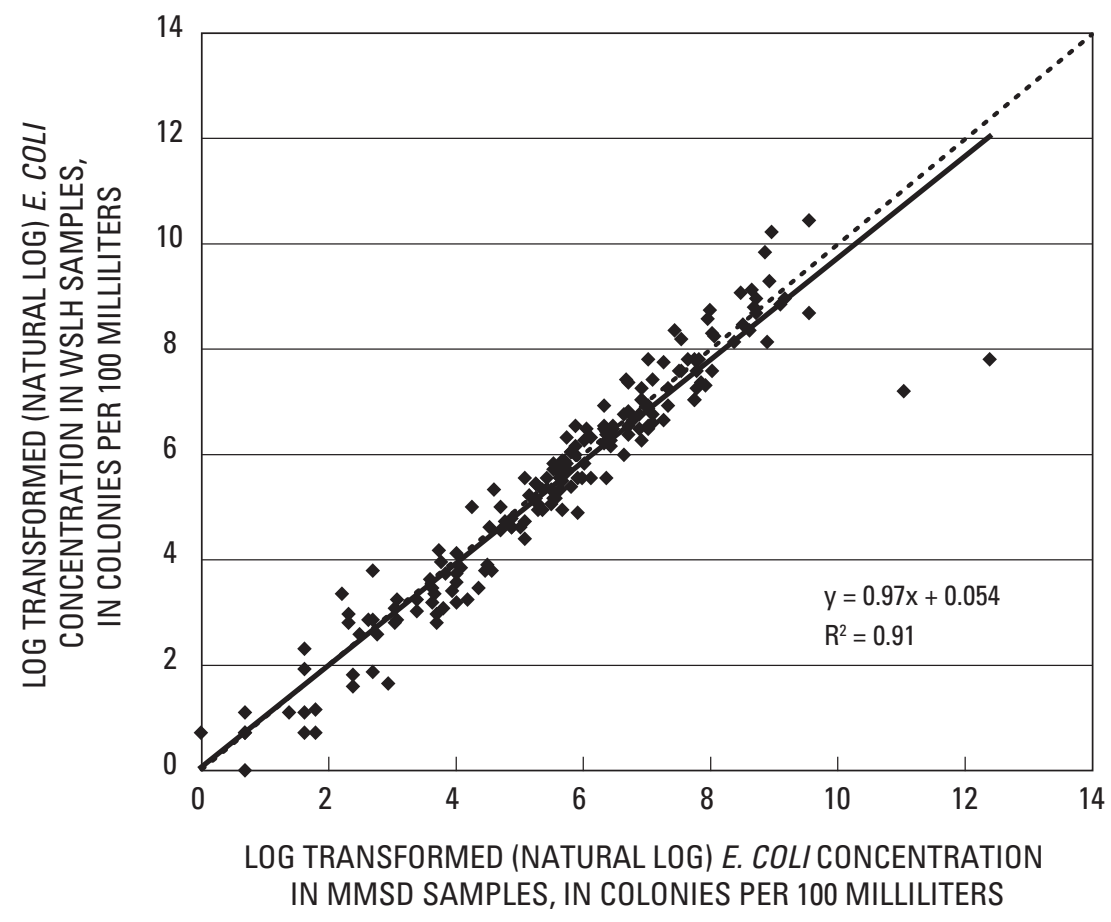

Figure 7. Inter-laboratory correlation between Phase II results for A, fecal coliform concentrations, and B, Escherichia coli concentrations from samples analyzed at the Wisconsin State Laboratory of Hygiene (WSLH) and Milwaukee Metropolitan Sewerage District (MMSD). 
Cryptosporidium, but were low for both. The maximum difference observed was three organisms (for Cryptosporidium), but the majority of differences ranged from 0 to 1 organism.

Variability in the replicate analyses for indicator and pathogen data sets may have stemmed from sample-collection techniques (replicates were collected as sequential grab samples), or analytical subsampling techniques. Attempts should be made to limit variability in future studies; however, for the purposes of this study the affect of sample variability for both indicator and pathogenic organisms were thought to be negligible.

All blank QC results for microbiological constituents were within data-quality limits.

\section{Bed Sediment}

Seven duplicate bed-sediment samples were collected from six sites during the study. In 2004, duplicate samples were collected from the Milwaukee River near Cedarburg, Milwaukee River at Milwaukee, Menomonee River at Wauwatosa, and Oak Creek sites. In 2005, duplicate samples were collected from the Willow Creek, Honey Creek, and Oak Creek sites. The duplicate samples were obtained by collecting a completely separate field sample from a second sediment trap deployed near the primary sediment trap. This approach was a way to qualitatively assess the combined effects of in-stream, sample-processing, and laboratory variability. The range of the RPDs between duplicate samples ranged from near 0 to 130 percent. Table 7 lists the variability in sediment trap results for duplicate samplers.

The largest source of variability associated with the sediment-trap samples appears to have been related to the variability of sediment-deposition patterns in the stream and the capture efficiency of the traps themselves. For example, duplicate samples at the Milwaukee River at Milwaukee site yielded two samples with recovered masses of $217 \mathrm{~g}$ and $1,714 \mathrm{~g}$. Such a difference between recovered sample masses suggested that the traps were placed within differing sediment-deposition zones. Alternatively, one trap at this location may have been covered by debris for part of the deployment time. For the Milwaukee River at Milwaukee site, RPDs between analytical results for the duplicate samples ranged from 10 to 62 percent. Duplicate samples at Willow Creek yielded recovered sediment masses of $903 \mathrm{~g}$ and $921 \mathrm{~g}$, suggesting that the traps were placed within very similar deposition zones. Correspondingly, the RPD between duplicates ranged from 4 to 14 percent.
Generally, the RPDs decreased for analytes as the mean concentration of the analyte increased relative to the reporting level. For the Milwaukee River at Milwaukee site, the RPD for mercury was 62 percent, with the mean concentration only about two times the reporting level. By contrast, the RPD for total PCBs at Milwaukee River at Milwaukee was about 10 percent, with the mean concentration of total PCBs greater than 40 times the reporting level.

For all sites, the pattern of contaminant concentrations was similar between duplicates for a given site; therefore, the relative site comparisons presented later in this report most likely reflect environmental conditions and are not the result of a single, irreproducible sample result.

\section{Water-Column Toxicity}

Six blanks and five replicate pairs were analyzed using the Microtox Acute Toxicity Test. Microtox results were reported as a percent difference in luminescence (compared to a laboratory control), therefore, members of replicate pairs could not be compared in the same manner as the majority of water-quality constituents.

For replicate-pair comparisons, percent effects were converted into percentages of laboratory-control fluorescence (that is, 100 percent minus the observed percent effect); variability in fluorescence percentages between members of replicate pairs was considered negligible, with RPDs ranging from 2 to 8 percent at the 5-minute reading and 3 to 8 percent at the 15 -minute reading.

Results for blanks ranged from -3.98 to 29.50 percent effect. Although one blank had higher percent effects than many environmental samples (at 26.99 and 29.50 percent effect at 5- and 15-minutes, respectively), overall, the percent effects observed in blanks were generally higher than those in environmental samples. Given the consistency of the results and the general lack of water-chemistry analytes found in blank water used for this study, these higher values were not thought to be indicative of contamination with toxic compounds, and may instead be indicative of low osmotic strength in the water (which could potentially decrease the viability of the marine bacterial species used in this analysis). 


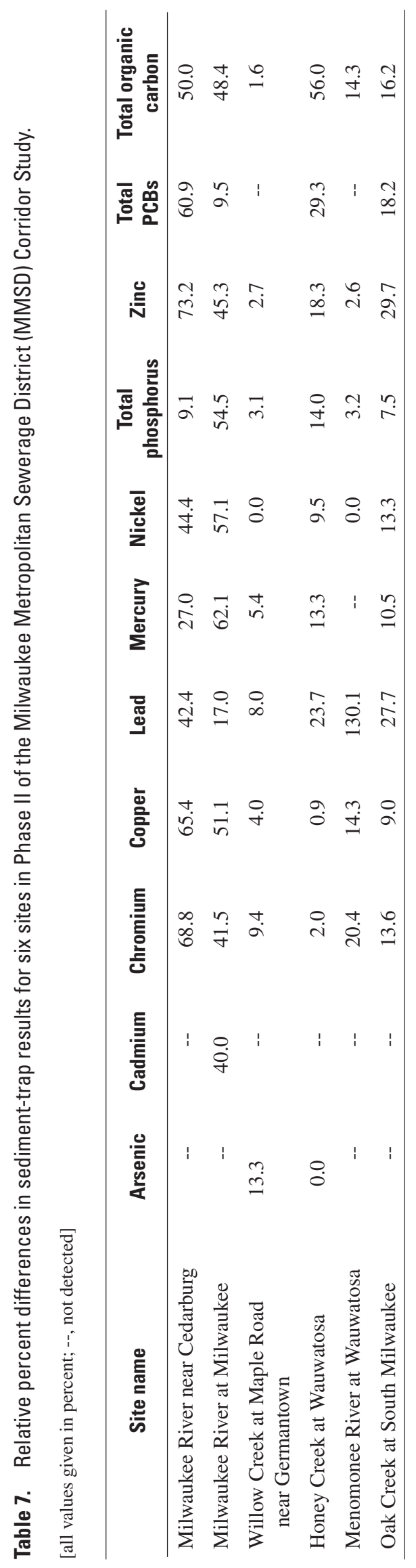




\section{Evaluation of Data Collected During Phase II}

This section summarizes data collected during Phase II. Each subsection highlights and describes only those constituents that either (1) require description because they were identified as data needs during Phase I of the MMSD Corridor Study or (2) demonstrate a statistical relationship, data distribution, or other consistent response that enhances the understanding of water quality as part of Phase II. Stream and harbor data are both discussed within each section: harbor sites are compared to other harbor sites, stream sites are compared to other stream sites, and general comparisons are made between stream and harbor sites.

Manually collected sampling events were assigned a category with respect to flow and season. Although personnel targeted high-flow events by selecting events in which the instantaneous discharge was greater than the 10-percent-flow-duration discharge at gages representing the major basins draining to the harbor, temporal variations in precipitation as well as the relative flashiness of smaller urban streams occasionally meant that a fraction of the streams were not at high flow at the time of targeted high-flow-event sampling. In addition, quarterly sampling was scheduled without regard for flow conditions, and therefore occasionally entailed the collection of samples during high-flow events. Therefore, flow condition at the time of sampling was assigned by examining 10-day hydrographs bracketing the sampling date ( 5 days before and after)(appendix 4). For stream sites without streamdischarge data, flow-condition estimates were based on comparisons to records from nearby streams. Seasonality was roughly based on the original sample purpose: quarterly samples were assigned to their season (spring, summer, autumn, and winter), snowmelt events were assigned to spring season, and summer storm events were assigned to summer. Specific seasonality assignments are listed in appendix 4. Overall, seasonal responses were explored for both stream and harbor sites. Only stream sites were considered with respect to flow.
Automatically collected samples were used for load determinations of chloride, total phosphorus, and suspended sediment at 4 of the 12 gaging stations that were continuously monitored for stream discharge. Samples were collected from June through September 2004 and for water year 2005. Daily loads of constituents at the four automatic-sampling sites were summed to monthly and annual totals. Loads are described with respect to total load, yield, yield per day, and volumetrically weighted (VW) concentration. Yield data (load data normalized to drainage area) were computed to allow for comparisons among the sites, whose drainage basins differ greatly in area: Milwaukee River near Cedarburg, $607 \mathrm{mi}^{2}$; Milwaukee River at Milwaukee, $690 \mathrm{mi}^{2}$; Menomonee River at Wauwatosa, $123 \mathrm{mi}^{2}$; and Kinnickinnic River, $18.8 \mathrm{mi}^{2}$. VW concentration was determined by dividing the total load by the total flow then multiplying by a conversion factor; this computation allowed for comparison of loads among various flow conditions.

General comparisons between Phase I and Phase II median concentrations were made where data were available for both phases and were sufficient to discern an overall pattern. Phase I median concentrations were calculated from available data; depending on the constituent, the amount of data ranged from a small dataset with only a few results to a large dataset with numerous results. Comparisons could not be made for a number of Phase II constituents (for example, the WWCs) as technology to analyze for many of these compounds has only recently been developed. The heterogeneity of the Phase I historical data set prohibited strict statistical comparisons (Schneider and others, 2004). The Phase I report (p. 11-23) describes how the Phase I data set was compiled and how the data can be used. Phase II sampling sites within subwatersheds were not necessarily located at the most downstream point of the subwatershed (fig. 1), and therefore, all data collected from the sites did not integrate water and sediment from the entire subwatershed. Additionally, the three Phase II sites in the Lower Milwaukee River subwatershed (Milwaukee River near Cedarburg, Milwaukee River at Milwaukee, and Milwaukee River at Mouth at Milwaukee) were not considered adequately representative of their subwatershed due to their location and the size and complexity of the Lower Milwaukee River subwatershed (table 8). Although all data are summarized in appendix 5, comparison of these sites to the subwatershed was omitted 
in the discussion of general comparisons between Phase I and Phase II data; however, contamination of this subwatershed with synthetic organic contaminants (especially PCBs) is well documented and is discussed in this report in general terms using the data from the Milwaukee River at Milwaukee site. Correlation between Phase I subwatersheds and Phase II sites is described in table 8 .
Where possible, percent differences in median concentrations were used to help quantify changes between Phase I and Phase II. Otherwise, comparisons were in terms of general increases or decreases in median concentrations. For this discussion, percent differences of 20 percent or greater were considered noteworthy. Quartile ranges used in maps were based on Phase I data (Schneider and others, 2004).

In addition, water- and bed-sediment-quality results were compared to USEPA criteria and (or) observed results (Robertson and others, 2006; Corsi and others, 1997; and MacDonald and others, 2000) where possible.

Table 8. Comparison of the Phase I subwatersheds to Phase II sites of the Milwaukee Metropolitan Sewerage District (MMSD) Corridor Study.

\begin{tabular}{llcc}
\hline \multicolumn{1}{c}{ Phase I subwatershed } & \multicolumn{1}{c}{ Phase Il site } & $\begin{array}{c}\text { Phase II } \\
\text { site abbreviation }\end{array}$ & $\begin{array}{c}\text { Phase II } \\
\text { site number }\end{array}$ \\
\hline Honey Creek & Honey Creek at Wauwatosa & HCW & 04087119 \\
Muskego Lake & Jewel Creek at Muskego & JCM & 05544371 \\
Kinnickinnic River & Kinnickinnic River at S. 11th Street at Milwaukee & KRM & 04087159 \\
Lincoln Creek & Lincoln Creek at 47th Street at Milwaukee & LCM & 040869415 \\
Little Menomonee River & Little Menomonee River at Milwaukee & LMM & 04087070 \\
Upper Menomonee River & Menomonee River at Menomonee Falls & MRMF & 04087030 \\
Lower Menomonee River & Menomonee River at Wauwatosa & MRW & 04087120 \\
Lower Milwaukee River ${ }^{1}$ & Milwaukee River near Cedarburg ${ }^{1}$ & MRC & 04086600 \\
& Milwaukee River at Milwaukee ${ }^{1}$ & MRM & 04087000 \\
Lower Oak Creek & Milwaukee River at Mouth at Milwaukee ${ }^{1}$ & MRJ & 04087170 \\
Upper Root River & Oak Creek at South Milwaukee & OCSM & 04087204 \\
Middle Root River & Root River at Grange Avenue at Greenfield & RRG & 04087214 \\
Underwood Creek & Root River near Franklin & RRF & 04087220 \\
Willow Creek & Underwood Creek at Wauwatosa & UCW & 04087088 \\
\hline
\end{tabular}

\footnotetext{
${ }^{1}$ Three of the Phase II sites sampled were in the Lower Milwaukee River Subwatershed. Comparisons are drawn individually between each site and the Phase I subwatershed.
} 


\section{Hydrologic Conditions During the Study Period}

Data for precipitation, stream discharge, and runoff at selected sites in the MMSD planning area are described in the following sections.

\section{Precipitation}

Precipitation data from the U.S. Department of Commerce, National Oceanic and Atmospheric Administration, and National Climatic Data Center (2003, 2004, 2005) were available at three sites within the MMSD planning area: Germantown Department of Public Works, Mount Mary College, and General Mitchell International Airport. Data collected at these sites during water years 2004 and 2005 were compared to monthly and yearly normals for 1971-2000 (table 9).

Total precipitation in water year 2004 was above normal at all sites: 7.64 in. above normal at Germantown, 1.32 in. above normal at Mount Mary College, and 0.23 in. above normal at General Mitchell Airport. At all three sites, the monthly precipitation totals in May 2004 were the highest recorded during the study period, and had the greatest departures from normal (ranging from 5.12 to 9.80 in.).

Total precipitation in water year 2005 was below normal at all sites: -9.29 in. at General Mitchell Airport, -6.64 in. at Mount Mary College, and -1.93 in. at Germantown. Monthly precipitation totals in March and April were among the lowest observed at all sites during water year 2005. The greatest departures from normal were in August (-2.74 in. at General Mitchell Airport and -2.42 in. at Mount Mary College) and April (-2.21 in. at Germantown).

\section{Discharge and Runoff}

Discharge is defined as the volume of water passing by a location over a given period of time. Runoff is defined as the depth to which the entire drainage area would be covered in water if the discharge for a given time period were evenly distributed across the area. Continuous stage measurements (that is, water-surface elevation above the datum of the stream gage) were collected and used to determine discharge and runoff during the study period at 12 of the 15 stream sites. At 8 of these sites, discharge records spanned more than 20 years, enabling comparisons of water year 2004-05 data with the long-term means for both discharge (appendixes 6A and 6C) and monthly runoff (appendixes 6B and 6C)(Waschbusch and others, 2005, 2006). At the remaining four sites, discharge records spanned shorter time periods, and are therefore provided without period of record comparisons (appendix 6A).

Annual mean discharges in water year 2004 were greater than long-term annual mean discharges for all eight long-term stream-gaging stations (appendix 6C). Percent differences from long-term annual means for water year 2004 ranged from 1 percent at Underwood Creek to 84 percent at the Milwaukee River at Milwaukee (appendix 6C). Sites with drainage basins in the southern portion of the MMSD planning area had the lowest percent differences: Underwood Creek (1 percent), Kinnickinnic River (6 percent), Oak Creek (7 percent), and Root River near Franklin (8 percent)(appendix 6C). Sites with drainage basins in the northern portion of the MMSD planning area had the highest percent differences: Milwaukee River at Milwaukee (84 percent), Milwaukee River near Cedarburg (56 percent), Menomonee River at Menomonee Falls (47 percent), and Menomonee River at Wauwatosa (44 percent)(appendix 6C). Runoff during May, June, and July, 2004, was greater than respective long-term at all eight long-term stream-gaging stations, with percent differences ranging from 16 in July at Kinnickinnic River to 538 percent in June at Milwaukee River at Milwaukee (appendixes 6B and 6C).

Annual mean discharges in water year 2005 were less than long-term annual mean discharges for all eight long-term stream-gaging stations (appendix 6c). Percent differences from long-term annual means for water year 2005 ranged from -50 percent at Menomonee River at Menomonee Falls to -16 percent at Milwaukee River at Milwaukee (appendix 6C). No spatial patterns in discharge data were observed in water year 2005. Runoff from March through August, 2005, was less than respective long-term means at all eight long-term stream-gaging stations, with percent differences ranging from -86 in June at Menomonee River at Menomonee Falls to -11 percent in March at Menomonee River at Menomonee Falls (appendixes $6 \mathrm{~B}$ and $6 \mathrm{C}$ ). 
Table 9. Monthly and water-year totals for rain gages in the Milwaukee Metropolitan Sewerage District planning area, Wis. (U.S. Department of Commerce, National Oceanic and Atmospheric Administration, and National Climatic Data Center, 2003, 2004, 2005).

[All data in inches; $\mathrm{M}$, total precipitation computed with 1-9 daily values missing]

\begin{tabular}{|c|c|c|c|c|c|c|c|c|c|}
\hline \multirow[b]{2}{*}{ Month } & \multicolumn{3}{|c|}{ Germantown Dept. of Public Works } & \multicolumn{3}{|c|}{ Mount Mary College } & \multicolumn{3}{|c|}{ General Mitchell International Airport } \\
\hline & $\begin{array}{c}\text { Total } \\
\text { precip- } \\
\text { itation }\end{array}$ & $\begin{array}{c}\text { Normal } \\
(1971-2000)\end{array}$ & $\begin{array}{c}\text { Departure } \\
\text { from normal }\end{array}$ & $\begin{array}{c}\text { Total } \\
\text { precip- } \\
\text { itation }\end{array}$ & $\begin{array}{c}\text { Normal } \\
(1971-2000)\end{array}$ & $\begin{array}{c}\text { Departure } \\
\text { from normal }\end{array}$ & $\begin{array}{c}\text { Total } \\
\text { precip- } \\
\text { itation }\end{array}$ & $\begin{array}{c}\text { Normal } \\
(1971-2000)\end{array}$ & $\begin{array}{l}\text { Departure } \\
\text { from normal }\end{array}$ \\
\hline \multicolumn{10}{|c|}{2004 water year } \\
\hline October & M 1.78 & 2.47 & -0.69 & 1.58 & 2.28 & -0.70 & 1.51 & 2.49 & -0.98 \\
\hline November & 5.67 & 2.59 & 3.08 & 2.98 & 2.35 & 63 & 3.94 & 2.70 & 1.24 \\
\hline December & 1.92 & 1.79 & .13 & 1.40 & 1.81 & -.41 & 2.03 & 2.22 & -.19 \\
\hline January & M 0.89 & 1.35 & -.46 & M 1.25 & 1.60 & -.35 & 1.43 & 1.85 & -.42 \\
\hline February & .98 & 1.20 & -.22 & M 0.77 & 1.31 & -.54 & 1.10 & 1.65 & -.55 \\
\hline March & 4.27 & 2.04 & 2.23 & M 3.31 & 1.95 & 1.36 & 3.99 & 2.59 & 1.40 \\
\hline April & 2.91 & 3.30 & -.39 & 2.44 & 3.41 & -.97 & 1.87 & 3.78 & -1.91 \\
\hline May & 12.83 & 3.03 & 9.80 & 9.74 & 2.85 & 6.89 & 8.18 & 3.06 & 5.12 \\
\hline June & 5.41 & 3.82 & 1.59 & 3.51 & 3.71 & -.2 & 4.07 & 3.56 & .51 \\
\hline July & 1.88 & 4.05 & -2.17 & 3.62 & 3.46 & 0.16 & 3.25 & 3.58 & -.33 \\
\hline August & 2.46 & 4.28 & -1.82 & 2.62 & 3.98 & -1.36 & 3.43 & 4.03 & -.6 \\
\hline September & .09 & 3.53 & -3.44 & .19 & 3.38 & -3.19 & .24 & 3.30 & -3.06 \\
\hline Total & 41.09 & 33.45 & 7.64 & 33.41 & 32.09 & 1.32 & 35.04 & 34.81 & 0.23 \\
\hline \multicolumn{10}{|c|}{2005 water year } \\
\hline October & 3.13 & 2.47 & 0.66 & 1.72 & 2.28 & -0.56 & 1.47 & 2.49 & -1.02 \\
\hline November & 2.25 & 2.59 & -.34 & 2.37 & 2.35 & .02 & 2.38 & 2.70 & -.32 \\
\hline December & 1.57 & 1.79 & -.22 & M 1.40 & 1.81 & -.41 & 1.53 & 2.22 & -.69 \\
\hline January & 3.48 & 1.35 & 2.13 & 3.67 & 1.60 & 2.07 & 3.31 & 1.85 & 1.46 \\
\hline February & 2.14 & 1.20 & .94 & M 1.26 & 1.31 & -.05 & 1.79 & 1.65 & .14 \\
\hline March & 1.22 & 2.04 & -.82 & 1.18 & 1.95 & -.77 & .72 & 2.59 & -1.87 \\
\hline April & 1.09 & 3.3 & -2.21 & 1.30 & 3.41 & -2.11 & 1.41 & 3.78 & -2.37 \\
\hline May & 3.31 & 3.03 & .28 & 2.90 & 2.85 & .05 & 2.62 & 3.06 & -.44 \\
\hline June & 1.91 & 3.82 & -1.91 & 2.14 & 3.71 & -1.57 & 2.23 & 3.56 & -1.33 \\
\hline July & 3.27 & 4.05 & -.78 & 2.32 & 3.46 & -1.14 & 2.60 & 3.58 & -.98 \\
\hline August & 3.56 & 4.28 & -.72 & 1.56 & 3.98 & -2.42 & 1.29 & 4.03 & -2.74 \\
\hline September & 4.59 & 3.53 & 1.06 & 3.63 & 3.38 & .25 & 4.17 & 3.30 & .87 \\
\hline Total & 31.52 & 33.45 & -1.93 & 25.45 & 32.09 & -6.64 & 25.52 & 34.81 & -9.29 \\
\hline
\end{tabular}




\section{Results from Manually and Automatically Collected Samples}

Data for more than 220 properties and constituents were collected during Phase II of the MMSD Corridor Study (appendix 3)(Waschbusch and others, 2005, 2006).

Results from field measurements ( $\mathrm{pH}$, specific conductance, dissolved oxygen, and temperature), major inorganics, and alkalinity gave a general description of area water quality, but did not indicate any unusual waterquality patterns that required further discussion or interpretation; a summary of results for these properties and constituents is given in table 10. Constituents of interest are detailed in the following discussions.

\section{Chloride}

Chloride naturally occurs in freshwater streams at low concentrations. Concentrations of chloride in rainwater are 0 to $2 \mathrm{mg} / \mathrm{L}$ and average concentrations of chloride in freshwater lakes and streams are 0 to $100 \mathrm{mg} / \mathrm{L}$ (Goldman and Horne 1983); concentrations in unpolluted streams generally contain less than $20 \mathrm{mg} / \mathrm{L}$. Salts containing chloride are often used for deicing roads in winter; roadsalt use in the United States amounts to between 8 and 12 million tons annually (Kunze and Sroka, 2004).

Chloride concentrations measured in Phase II stream sites ranged from 30.2 to $971 \mathrm{mg} / \mathrm{L}$, with a median concentration of $146 \mathrm{mg} / \mathrm{L}$. Highest median concentrations were observed in streams whose drainage areas are small (less than $19 \mathrm{mi}^{2}$ ) and highly urban (greater than 80 percent), such as Underwood Creek (295 mg/L), Honey Creek (260 mg/L), Lincoln Creek (246 mg/L), and Root River at Grange Avenue (246 mg/L)(table 1A, fig.2, fig. 8). Chloride concentrations indicated a positive relation with increasing urban land use (fig. 9). Lowest median concentrations were observed in streams whose drainage areas

Table 10. Median results for field measurements, major inorganics, and alkalinity that did not indicate any unusual water-quality patterns. Results are summarized for 15 stream sites and 6 harbor Phase II sites in the Milwaukee Metropolitan Sewerage District planning area, Wis.

[mg/L, milligram per liter; $\mu \mathrm{g} / \mathrm{L}$, microgram per liter; $\mu \mathrm{S} / \mathrm{cm}$, microsiemen per centimeter]

\begin{tabular}{|c|c|c|c|}
\hline Property or constituent name & Unit & $\begin{array}{c}\text { Stream } \\
\text { median value }\end{array}$ & $\begin{array}{l}\text { Harbor } \\
\text { median value }\end{array}$ \\
\hline $\begin{array}{l}\text { Alkalinity, water, filtered, fixed endpoint ( } \mathrm{pH} 4.5 \text { ) titration, } \\
\text { laboratory }\end{array}$ & $\mathrm{mg} / \mathrm{L}$ as calcium carbonate & 176 & 114 \\
\hline Alkalinity, water, filtered, incremental titration, field & $\mathrm{mg} / \mathrm{L}$ as calcium carbonate & 169 & 110 \\
\hline Calcium, water, filtered & $\mathrm{mg} / \mathrm{L}$ & 61.6 & 36.1 \\
\hline Dissolved oxygen, water, unfiltered & $\mathrm{mg} / \mathrm{L}$ & 9.9 & 10.7 \\
\hline Fluoride, water, filtered & $\mathrm{mg} / \mathrm{L}$ & 0.20 & 0.20 \\
\hline Iron, water, filtered & $\mu \mathrm{g} / \mathrm{L}$ & 34.5 & 6 \\
\hline Magnesium, water, filtered & $\mathrm{mg} / \mathrm{L}$ & 28.2 & 12.5 \\
\hline Manganese, water, filtered & $\mu \mathrm{g} / \mathrm{L}$ & 20 & 0.8 \\
\hline $\mathrm{pH}$, water, unfiltered, field & standard units & 7.9 & 8.0 \\
\hline $\mathrm{pH}$, water, unfiltered, laboratory & standard units & 7.9 & 8.0 \\
\hline Potassium, water, filtered & $\mathrm{mg} / \mathrm{L}$ & 3.35 & 1.78 \\
\hline Silica, water, filtered & $\mathrm{mg} / \mathrm{L}$ & 6.10 & 1.28 \\
\hline Sodium, water, filtered & $\mathrm{mg} / \mathrm{L}$ & 75.8 & 11.4 \\
\hline Specific conductance, water, unfiltered, laboratory & $\mu \mathrm{S} / \mathrm{cm}$ & 875 & 308 \\
\hline Specific conductance, water, unfiltered, field & $\mu \mathrm{S} / \mathrm{cm}$ & 952 & 310 \\
\hline Sulfate, water, filtered & $\mathrm{mg} / \mathrm{L}$ & 42.8 & 24.1 \\
\hline
\end{tabular}




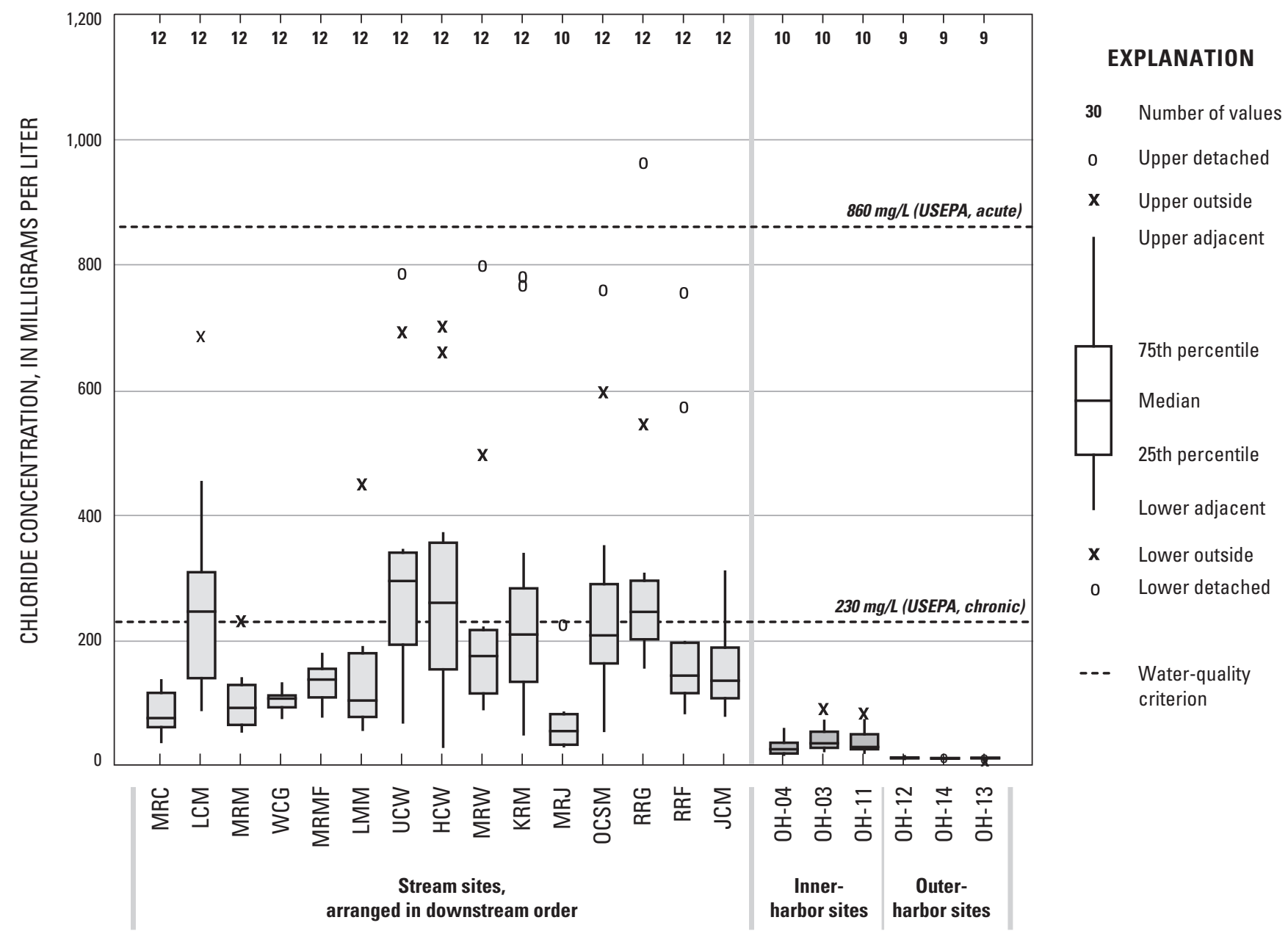

Figure 8. Distribution of chloride concentrations, by site, in the Milwaukee Metropolitan Sewerage District planning area, Wis. Water-quality criteria lines represent the U.S. Environmental Protection Agency national chronic and acute freshwaterquality criteria for non-priority pollutants for chloride in surface water ( $230 \mathrm{mg} / \mathrm{L}$ and $860 \mathrm{mg} / \mathrm{L}$, respectively) (U.S. Environmental Protection Agency, 2006e). Site abbreviations listed in table 1. 


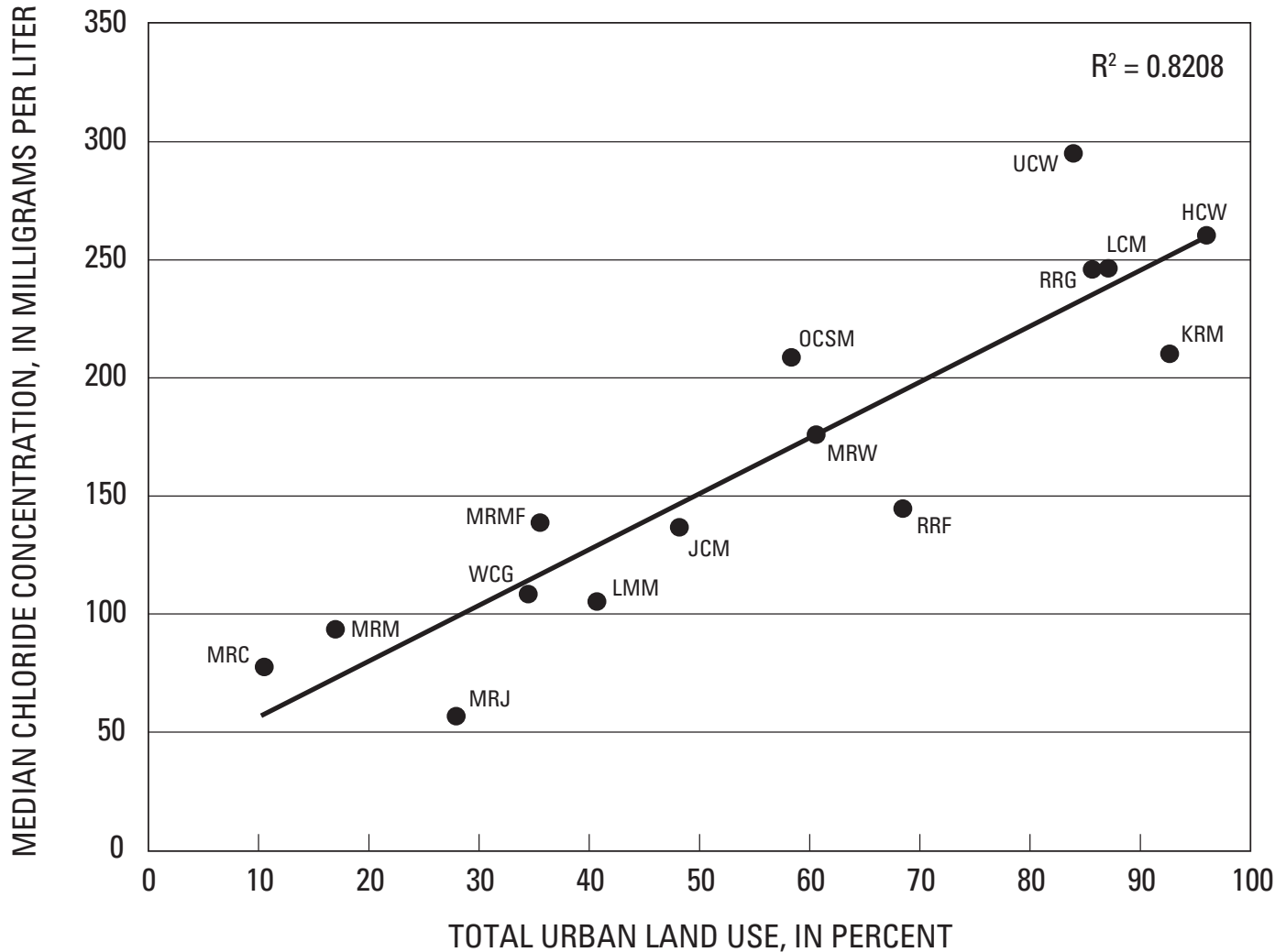

Figure 9. Median chloride concentrations plotted against percent urban land use in drainage basins for 15 stream sites in the Milwaukee Metropolitan Sewerage District planning area, Wis. Site abbreviations listed in table 1.

are large (greater than $600 \mathrm{mi}^{2}$ ) and more heterogeneous in land use: Milwaukee River at Mouth (54.9 mg/L), Milwaukee River at Milwaukee (91.9 mg/L), and Milwaukee River near Cedarburg (75.9 mg/L). Forty-three samples (from 12 stream sites) had concentrations above the USEPA national chronic freshwater-quality criterion of $230 \mathrm{mg} / \mathrm{L}$ for nonpriority pollutants (U.S. Environmental Protection Agency, 2006d). One sample collected from Root River at Grange Avenue in February, 2004, had a concentration above the USEPA national acute freshwater-quality criterion of 860 $\mathrm{mg} / \mathrm{L}$ for non-priority pollutants (U.S. Environmental Protection Agency, 2006d).

Stream sites indicated no consistent response in chloride concentration with respect to flow (fig. 10A). With respect to seasonal response, median chloride concentrations were highest during the winter (482 mg/L); median concentrations ranged from 115 to $175 \mathrm{mg} / \mathrm{L}$ for remaining seasons (fig. 10B).

Data were available for Phase I and Phase II chloride concentration comparisons at eight sites (appendix 5). At seven of those sites, median chloride concentra- tions measured in Phase II were notably higher than those measured in Phase I, with percent differences ranging from 29 percent at Root River at Grange Avenue to 289 percent at Kinnickinnic River. This increase likely was due to the lack of Phase I data collected during winter months, whereas winter and snowmelt sample collection was part of Phase II. Only the Root River near Franklin site indicated no notable difference.

Median chloride concentrations measured in harbor samples ranged from 10.6 to $98.9 \mathrm{mg} / \mathrm{L}$. Harbor samples had notably lower median concentrations $(19.3 \mathrm{mg} / \mathrm{L})$ than stream sites (146 mg/L). Inner-harbor sites (26.1-35.4 $\mathrm{mg} / \mathrm{L}$ ) had higher median concentrations than outer-harbor sites (11.4-11.9 mg/L)(fig. 8). Harbor samples collected in spring had the highest median concentration $(36.2 \mathrm{mg} / \mathrm{L})$ and the highest degree of variability (fig. 10d). Samples collected during summer and autumn had lower median concentrations (14.6 and $17.7 \mathrm{mg} / \mathrm{L}$, respectively) than those collected during spring $(36.2 \mathrm{mg} / \mathrm{L})$. No winter samples were collected at harbor sites. 


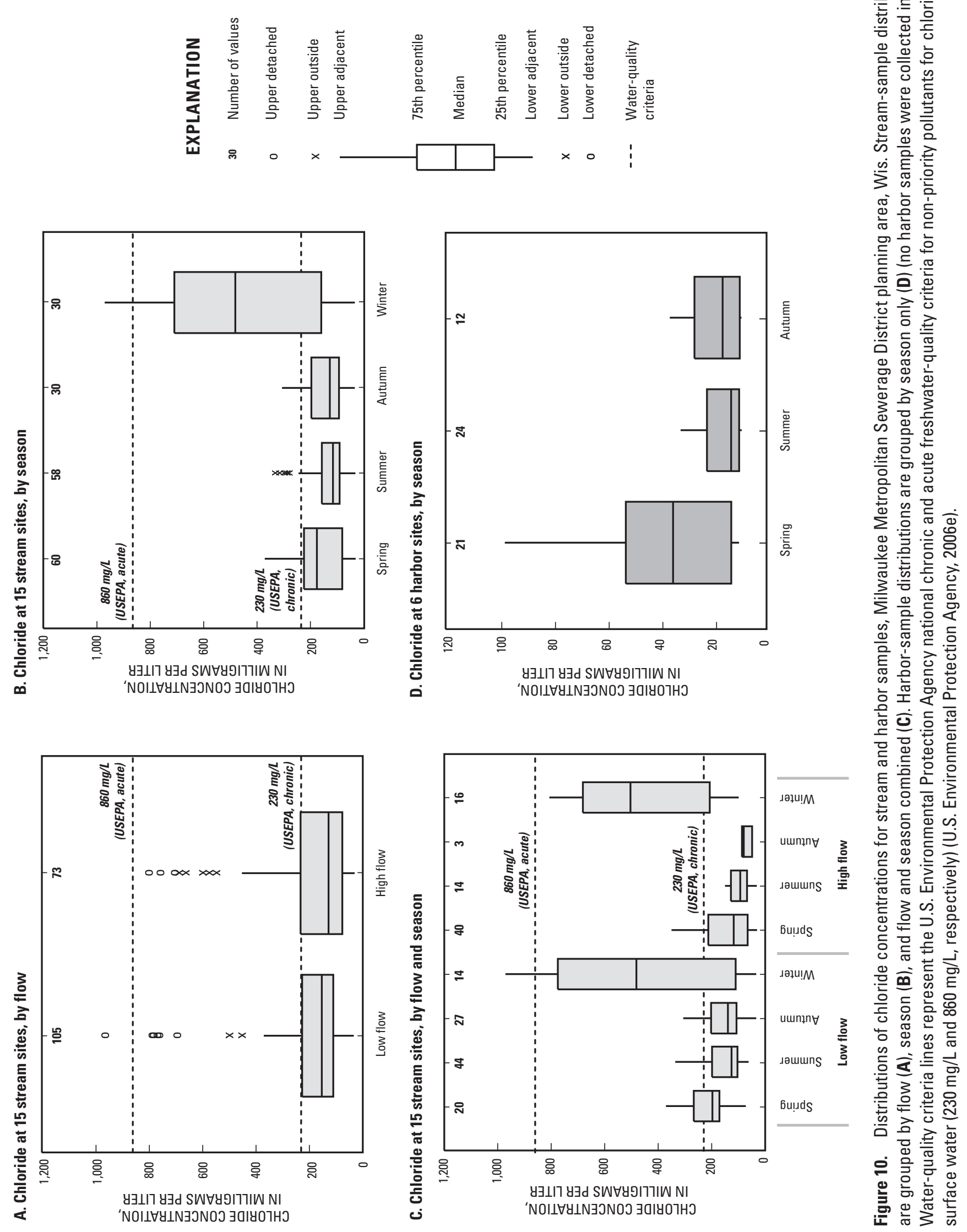


Loads, Yields, and Volumetrically Weighted Concentrations of Chloride

Chloride loads for June through September 2004 ranged from 858 tons at Kinnickinnic River to 12,900 tons at Milwaukee River at Milwaukee (table 11). VW concentrations ranged from $41 \mathrm{mg} / \mathrm{L}$ at Milwaukee River near Cedarburg to $101 \mathrm{mg} / \mathrm{L}$ at Menomonee River at Wauwatosa. The average daily chloride yield ranged from 0.15 tons $/ \mathrm{mi}^{2} / \mathrm{d}$ at the Milwaukee River near Cedarburg and Milwaukee River at Milwaukee sites to 0.37 tons $/ \mathrm{mi}^{2} / \mathrm{d}$ at the Kinnickinnic River site. In water year 2005, chloride loads ranged from 5,940 tons at Kinnickinnic River to 32,700 tons at Milwaukee River at Milwaukee. VW concentrations ranged from $69 \mathrm{mg} / \mathrm{L}$ at Milwaukee River near Cedarburg to $349 \mathrm{mg} / \mathrm{L}$ at Kinnickinnic River. VW chloride concentrations of $245 \mathrm{mg} / \mathrm{L}$ at Menomonee River at Wauwatosa and $349 \mathrm{mg} / \mathrm{L}$ at Kinnickinnic River were above the USEPA national chronic freshwater-quality criterion of $230 \mathrm{mg} / \mathrm{L}$ for non-priority pollutants, but below the USEPA national acute freshwater-quality criterion of $860 \mathrm{mg} / \mathrm{L}$ for non-priority pollutants (U.S. Environmental Protection Agency, 2006d). The average daily yields ranged from 0.10 tons $/ \mathrm{mi}^{2} / \mathrm{d}$ at Milwaukee River near Cedarburg to 0.87 tons $/ \mathrm{mi}^{2} / \mathrm{d}$ at Kinnickinnic River.

There was a seasonal pattern in chloride loads in water year 2005 with generally higher loads being recorded in January through March (table 12). The greatest monthly loads of chloride for data collected in 2004 were in June, likely a result of the high stream discharge that month (Milwaukee River near Cedarburg had 357 percent greater runoff than normal).

Table 11. Annual chloride load and yield, average daily chloride yield, total water flow, and volumetric total chloride concentrations for four Phase II sites in the Milwaukee Metropolitan Sewerage District planning area, Wis.

[tons $/ \mathrm{mi}^{2}$, tons per square mile; tons $/ \mathrm{mi}^{2} / \mathrm{d}$, tons per square mile per day; $\mathrm{ft}^{3} / \mathrm{s}$, cubic foot per second; $\mathrm{mg} / \mathrm{L}$, milligram per liter; values in bold are for complete water years]

\begin{tabular}{|c|c|c|c|c|c|c|}
\hline $\begin{array}{l}\text { Water } \\
\text { year }\end{array}$ & $\begin{array}{l}\text { Months } \\
\text { sampled }\end{array}$ & $\begin{array}{l}\text { Chloride load } \\
\text { (tons) }\end{array}$ & $\begin{array}{l}\text { Chloride yield } \\
\text { (tons } / \mathrm{mi}^{2} \text { ) }\end{array}$ & $\begin{array}{l}\text { Average daily } \\
\text { chloride yield } \\
\text { (tons } / \mathrm{mi}^{2} / \mathrm{d} \text { ) }\end{array}$ & $\begin{array}{c}\text { Total water flow } \\
\left(\mathrm{ft}^{3} / \mathrm{s}\right)\end{array}$ & $\begin{array}{l}\text { Volumetric chloride } \\
\text { concentration } \\
\text { (mg/L) }\end{array}$ \\
\hline \multicolumn{7}{|c|}{ Milwaukee River near Cedarburg } \\
\hline 2004 & June-Sept. & 10,900 & 18.0 & 0.15 & 98,100 & 41 \\
\hline 2005 & Oct.-Sept. & 21,200 & 34.9 & .10 & 114,000 & 69 \\
\hline \multicolumn{7}{|c|}{ Milwaukee River at Milwaukee } \\
\hline 2004 & June-Sept. & 12,900 & 18.5 & .15 & 114,000 & 42 \\
\hline 2005 & Oct.-Sept. & 32,700 & 47.0 & .13 & 132,000 & 92 \\
\hline \multicolumn{7}{|c|}{ Menomonee River at Wauwatosa } \\
\hline 2004 & June-Sept. & 3,640 & 29.5 & .24 & 13,300 & 101 \\
\hline 2005 & Oct.-Sept. & 17,600 & 143 & .39 & 26,600 & 245 \\
\hline \multicolumn{7}{|c|}{ Kinnickinnic River at S. 11th Street at Milwaukee } \\
\hline 2004 & June-Sept. & 858 & 45.6 & .37 & 3,370 & 94 \\
\hline 2005 & Oct.-Sept. & 5,940 & 316 & .87 & 6,320 & 349 \\
\hline
\end{tabular}


Table 12. Monthly and annual chloride loads for four Phase II sites in the Milwaukee Metropolitan Sewerage District planning area, Wis., for water years 2004 and 2005.

[WY, water year]

\begin{tabular}{|c|c|c|c|c|}
\hline \multirow[b]{2}{*}{ Month } & \multicolumn{4}{|c|}{ Chloride (tons) } \\
\hline & $\begin{array}{l}\text { Milwaukee River } \\
\text { near Cedarburg }\end{array}$ & $\begin{array}{l}\text { Milwaukee River } \\
\text { at Milwaukee }\end{array}$ & $\begin{array}{l}\text { Menomonee River } \\
\text { at Wauwatosa }\end{array}$ & $\begin{array}{l}\text { Kinnickinnic River } \\
\text { at S. 11th Street } \\
\text { at Milwaukee }\end{array}$ \\
\hline \multicolumn{5}{|c|}{ Water year 2004} \\
\hline June & 5,620 & 6,750 & 1,970 & 348 \\
\hline July & 2,410 & 2,920 & 1,000 & 231 \\
\hline August & 1,680 & 2,100 & 454 & 177 \\
\hline September & 1,150 & 1,170 & 211 & 102 \\
\hline WY total & 10,900 & 12,900 & 3,640 & 858 \\
\hline \multicolumn{5}{|c|}{ Water year 2005} \\
\hline October & 1,180 & 1,410 & 272 & 97 \\
\hline November & 1,500 & 1,620 & 374 & 138 \\
\hline December & 2,180 & 2,430 & 838 & 271 \\
\hline January & 2,270 & 4,290 & 2,530 & 1,260 \\
\hline February & 2,440 & 5,040 & 5,100 & 1,930 \\
\hline March & 3,450 & 5,080 & 3,750 & 963 \\
\hline April & 2,540 & 3,560 & 1,900 & 371 \\
\hline May & 1,980 & 4,710 & 1,280 & 299 \\
\hline June & 968 & 1,370 & 513 & 184 \\
\hline July & 1,050 & 1,270 & 336 & 152 \\
\hline August & 614 & 852 & 271 & 102 \\
\hline September & 988 & 1,070 & 455 & 177 \\
\hline WY total & 21,200 & 32,700 & 17,600 & 5,940 \\
\hline
\end{tabular}




\section{Nutrients and Chlorophyll a}

Concentrations of total nitrogen, nitrate, total phosphorus, and chlorophyll $a$ are primary indicators of nutrient enrichment in streams (U.S. Environmental Protection Agency, 2000), and samples for these constituents were collected at all Phase II sites during each site visit. The USEPA has established proposed nutrient criteria for the continental U.S.; these criteria are specific to regional areas, or ecoregions. Ecoregions are defined as areas of similar natural geographic characteristics and land-use patterns, and include geology, physiography, vegetation, climate, soils, wildlife, and hydrology. Ecoregions can be defined at multiple scales. For example, there are 14 Nutrient ecoregions and 84 Level III ecoregions in the conterminous United States; Nutrient ecoregions are aggregations of Level III ecoregions where the characteristics affecting nutrient levels are expected to be similar. Nutrient ecoregions can form the basis for initial development of nutrient criteria, however small-scale variability and accuracy may be lost during the aggregation of data for these large areas. Level III ecoregions are smaller and more homogenous; therefore Level III criteria can provide more accurate reference conditions for smaller-scale studies. Additionally, the USEPA encourages states and authorized tribes to further subdivide these regions and establish more refined criteria where possible.

The MMSD planning area is located in Nutrient ecoregion VII and Level III Ecoregion 53; the USEPA criteria for these ecoregions are defined in table 13 (U.S. Environmental Protection Agency, 2000). These criteria are the USEPA's recommendations to states and authorized tribes for use in establishing their water-quality standards consistent with section 303(c) of the Clean Water Act
(U.S. Environmental Protection Agency, 2000), and reflect estimated nutrient concentrations in reference streams from these areas. Nutrient Ecoregion VII is the "mostly glaciated dairy region" that includes the southern twothirds of Wisconsin and Michigan and parts of Minnesota, Illinois, Indiana, Ohio, Pennsylvania, and New York (U.S. Environmental Protection Agency, 2000). Level III Ecoregion 53, the "Southeastern Wisconsin Till Plains," includes the area northward from the Wisconsin-Illinois border to Green Bay, Wis., and stretches eastward from central Wisconsin to Lake Michigan. Additional reference concentrations for total nitrogen, total phosphorus, and chlorophyll $a$ have been defined for wadeable Wisconsin streams by Robertson and others (2006), and are included to provide another benchmark for assessing water-quality.

Whereas concentrations of nutrients and chlorophyll $a$ at stream sites could be compared against the USEPA criteria, concentrations of total phosphorus and chlorophyll $a$ at harbor sites can be compared against ranges for trophic classes; trophic classes are a traditional system for describing the water quality of lakes as oligotrophic (low nutrient concentrations, low algal populations), mesotrophic (moderate nutrient concentrations, prone to moderate algal blooms), and eutrophic (high nutrient concentrations, prone to frequent seasonal algal blooms). The trophic state index (TSI) was developed to allow for lake classification according to concentrations of total phosphorus, chlorophyll $a$, and Secchi depth (Carlson, 1977). TSI values of 40 and 50 bound the range of concentrations indicating mesotrophic conditions. Corresponding concentrations of total phosphorus $(0.012-0.024 \mathrm{mg} / \mathrm{L})$ and chlorophyll $a$ $(2.60-7.20 \mu \mathrm{g} / \mathrm{L})$ were used to classify observed sample concentrations from harbor sites.

Table 13. Estimated nutrient concentrations in reference streams for the area encompassing the Milwaukee Metropolitan Sewerage District planning area, Wis.

[mg/L, milligram per liter; $\mu \mathrm{g} / \mathrm{L}$, microgram per liter; --, not determined]

\begin{tabular}{|c|c|c|c|c|}
\hline \multirow{2}{*}{$\begin{array}{l}\text { Nutrient indicator } \\
\text { constituent }\end{array}$} & \multirow{2}{*}{ Unit } & \multicolumn{2}{|c|}{$\begin{array}{l}\text { U.S. Environmental Protection Agency } \\
\text { proposed nutrient criteria (2000) }\end{array}$} & \multirow{2}{*}{$\begin{array}{l}\text { Reference concentration } \\
\text { (Robertson and others, } \\
\text { 2006) }\end{array}$} \\
\hline & & Nutrient Ecoregion VII & Level III Ecoregion 53 & \\
\hline $\begin{array}{l}\text { Total nitrogen (nitrate }+ \text { nitrite }+ \\
\text { ammonia }+ \text { organic nitrogen), water, } \\
\text { unfiltered, analytically determined }\end{array}$ & $\mathrm{mg} / \mathrm{L}$ & 0.54 & 1.59 & 0.40 \\
\hline Nitrite plus nitrate, water, filtered & $\mathrm{mg} / \mathrm{L}$ & .30 & .94 & -- \\
\hline Phosphorus, water, unfiltered & $\mathrm{mg} / \mathrm{L}$ & .033 & .08 & $0.03-0.04$ \\
\hline $\begin{array}{l}\text { Chlorophyll } a, \text { water, unfiltered, } \\
\text { trichromatic method, uncorrected }\end{array}$ & $\mu \mathrm{g} / \mathrm{L}$ & 5.8 & -- & 1.0 \\
\hline
\end{tabular}




\section{Total Nitrogen}

Total nitrogen concentrations in streams sampled in Phase II ranged from 0.30 to $4.44 \mathrm{mg} / \mathrm{L}$ with a median concentration of $1.33 \mathrm{mg} / \mathrm{L}$. The median concentration was less than the USEPA proposed criterion of $1.59 \mathrm{mg} / \mathrm{L}$ for total nitrogen in Level III Ecoregion 53 (table 13)(U. S. Environmental Protection Agency, 2000). At Milwaukee River near Cedarburg $(2.14 \mathrm{mg} / \mathrm{L})$ and Milwaukee River at Milwaukee $(1.89 \mathrm{mg} / \mathrm{L})$, median concentrations were greater than the USEPA criterion. For the remaining streams, median concentrations ranged from 0.98 to 1.43 $\mathrm{mg} / \mathrm{L}$, all of which were greater than the reference concentration of $0.4 \mathrm{mg} / \mathrm{L}$ proposed by Robertson and others (2006). The maximum total nitrogen concentration, 4.44 $\mathrm{mg} / \mathrm{L}$, was measured at Honey Creek during the snowmelt sampling event in March 2004 (fig. 11). Land use did not correlate appreciably with total nitrogen throughout the MMSD planning area.

Median concentrations of total nitrogen at all stream samples were notably higher during high flow $(2.02 \mathrm{mg} / \mathrm{L})$ than during low flow (1.13 mg/L)(fig. 12A). Notable seasonality also was evident in total nitrogen concentrations. Highest median and greatest variability occurred during spring $(1.98 \mathrm{mg} / \mathrm{L})$ and winter $(2.05 \mathrm{mg} / \mathrm{L})$ (figure 12B). Median total nitrogen concentrations measured during spring high flow $(2.12 \mathrm{mg} / \mathrm{L})$ were higher than those measured during spring low flow $(1.47 \mathrm{mg} / \mathrm{L})$. Winter median concentrations measured during high flow $(2.16 \mathrm{mg} / \mathrm{L})$ were also higher than those measured during winter low flow (1.29 mg/L)(fig. 12C).
Data were available for Phase I and Phase II nitrogen concentration comparisons at 11 sites (appendix 5). Median total nitrogen concentrations at five of those sites decreased from Phase I to Phase II; among these sites, percent differences ranged from -21 percent at Lincoln Creek to -57 percent at Little Menomonee River. Honey Creek was the only site with a notable increase from Phase I to Phase II (288 percent difference). At the remaining five sites, no notable differences were observed from Phase I to Phase II (fig. 13).

Total nitrogen concentration in harbor samples ranged from 0.35 to $2.71 \mathrm{mg} / \mathrm{L}$. Harbor samples had a notably lower overall median concentration $(0.63 \mathrm{mg} / \mathrm{L})$ than stream samples did $(1.33 \mathrm{mg} / \mathrm{L})$. Inner-harbor sites had higher median concentrations $(0.79-1.08 \mathrm{mg} / \mathrm{L})$ than outer-harbor sites $(0.44-0.48 \mathrm{mg} / \mathrm{L})$. Harbor samples collected in spring had the highest median concentration $(0.91$ $\mathrm{mg} / \mathrm{L}$ ) and were the most variable (fig. 12D). 


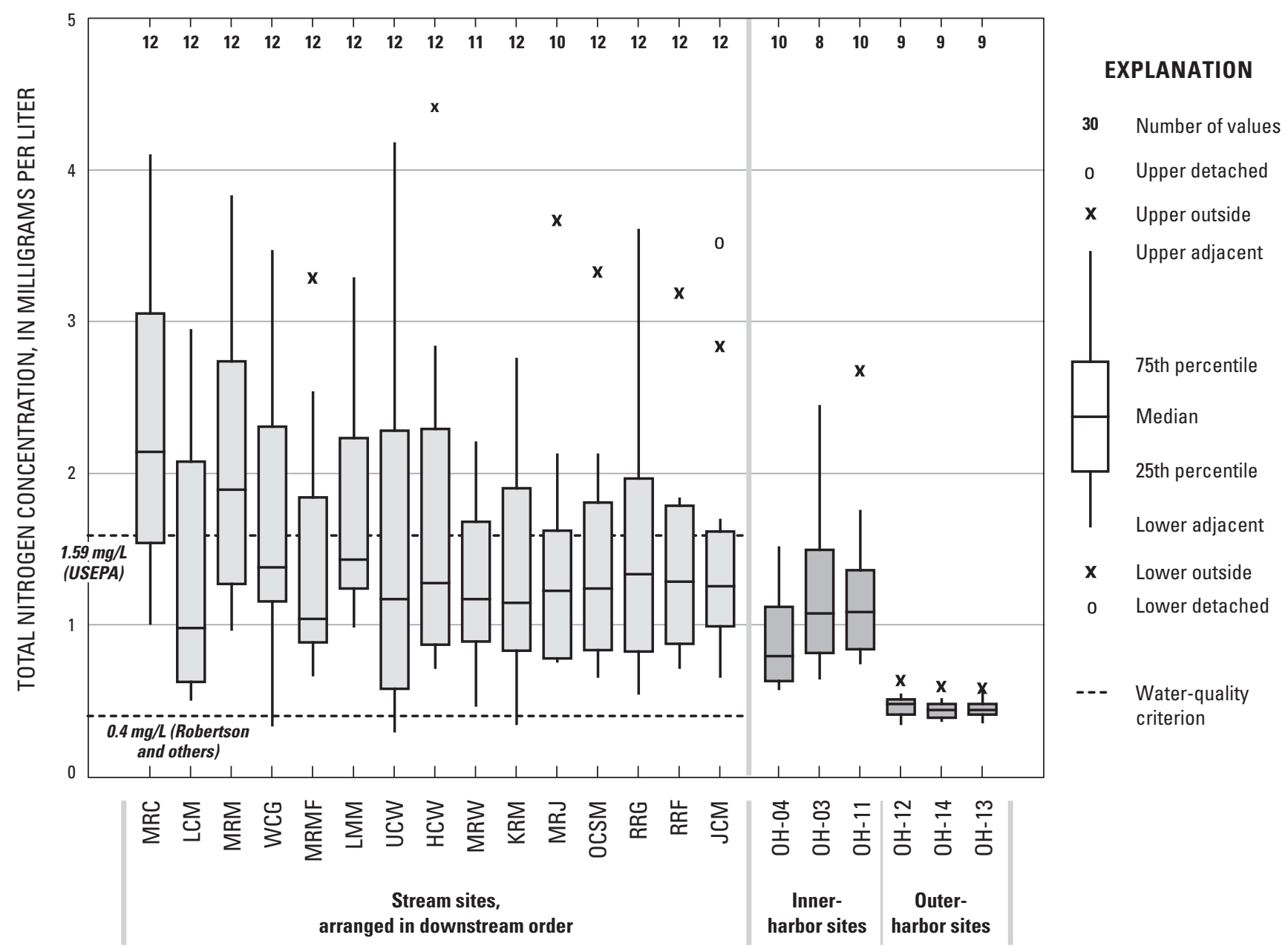

Figure 11. Distribution of total nitrogen concentrations, by site, in the Milwaukee Metropolitan Sewerage District planning area, Wis. Water-quality criteria lines represent the U.S. Environmental Protection Agency proposed nutrient criterion for total nitrogen in Level III Ecoregion 53 streams (1.59 mg/L)(U.S. Environmental Protection Agency, 2000) and the reference concentration for wadeable Wisconsin streams (0.4 mg/L), as defined by Robertson and others (2006). Site abbreviations listed in table 1. 

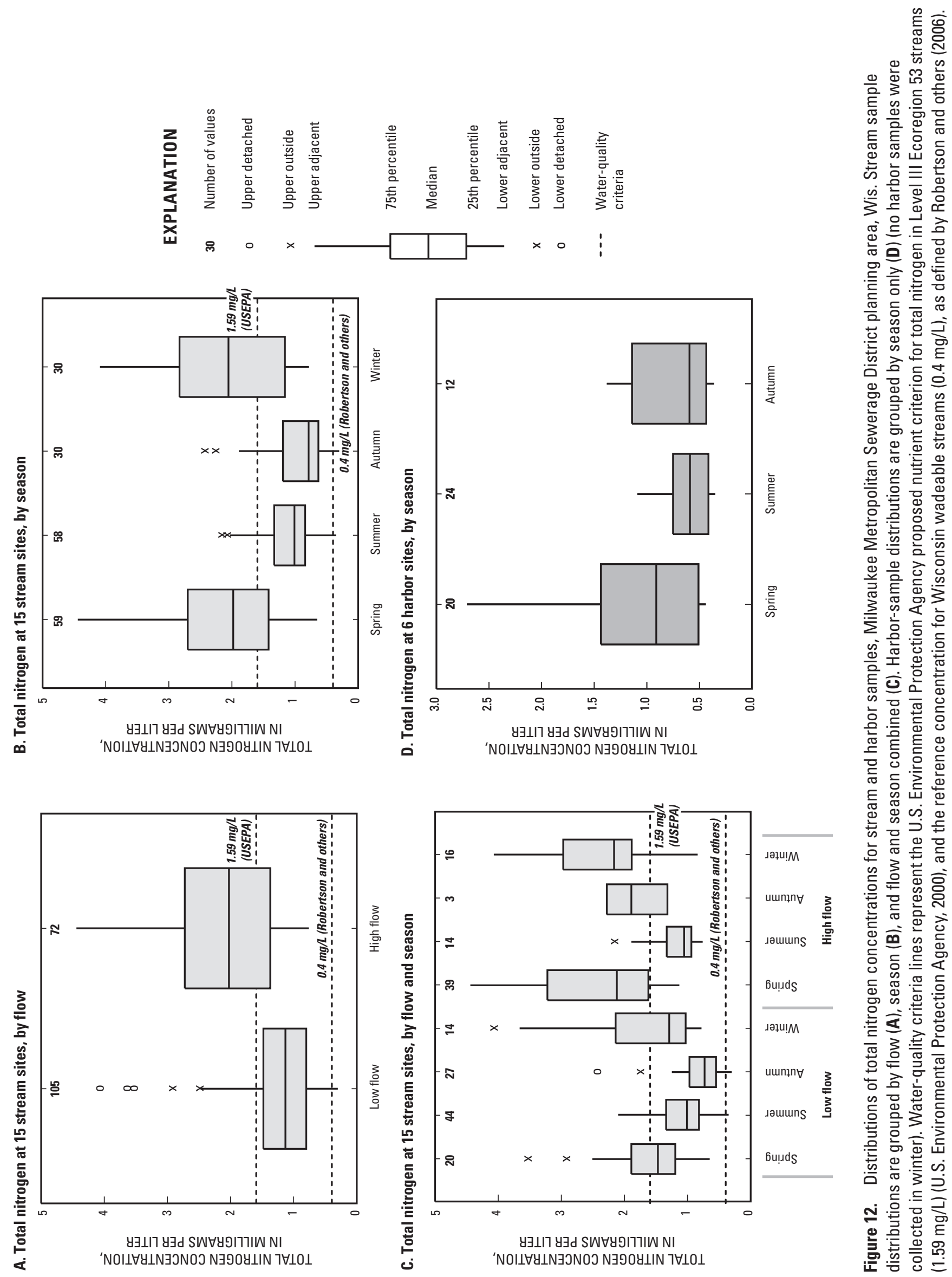


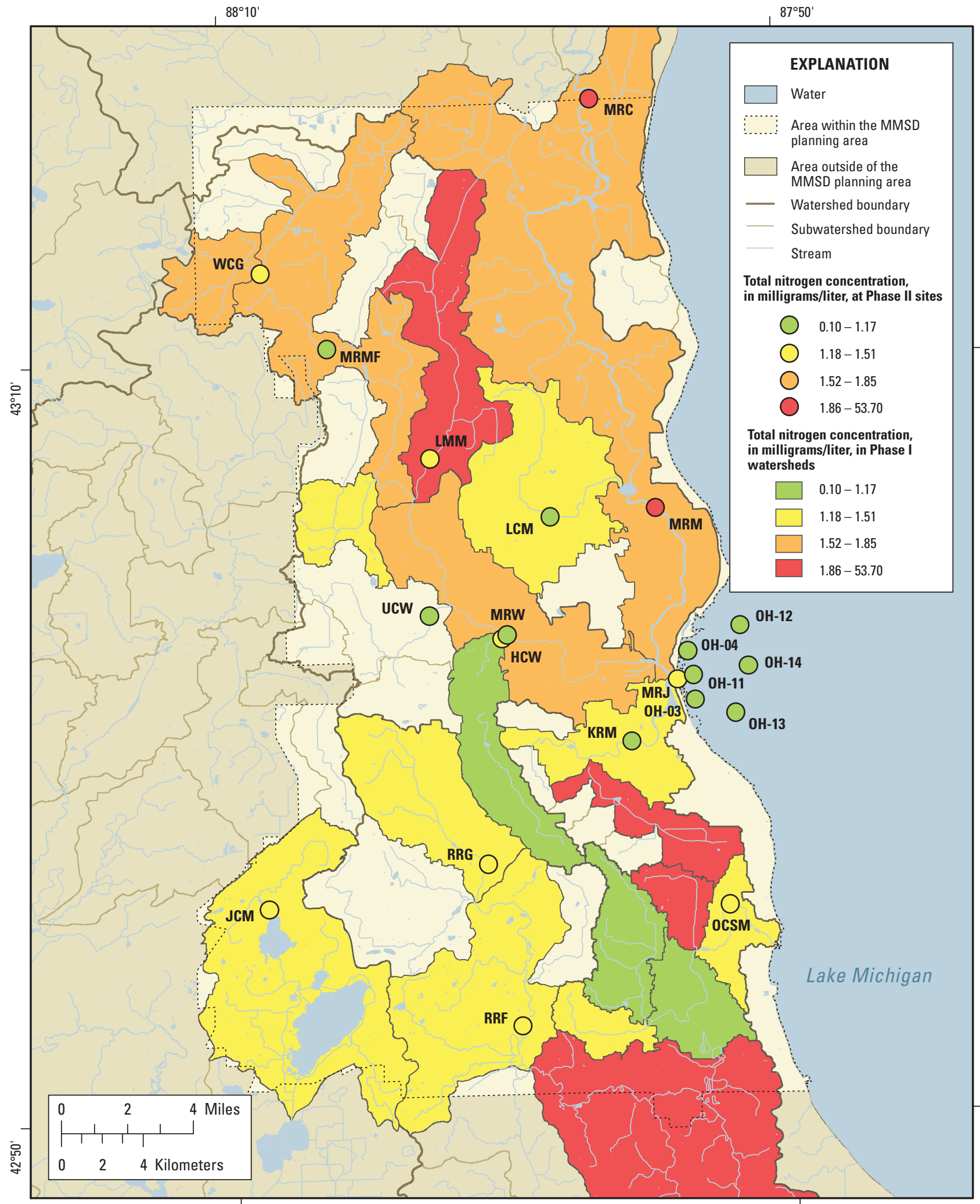

Base composited from Southeastern Wisconsin Regional Planning Commission regional base map, 1:2,000, 1995; U.S. Geological Survey digital line graph hydrography, 1:100,000, 1989; Wisconsin Department of Natural Resources version 2 hydrography, 1:24,000, 2002. Wisconsin Transverse Mercator Projection, referenced to North American Datum of 1983, 1991 adjustment.

Figure 13. Phase I and Phase II comparison of median total nitrogen concentrations in the Milwaukee Metropolitan Sewerage District (MMSD) planning area, Wis. Phase I values are shown by subwatershed values and quartiles, Phase II values are shown by site using the same quartile. Site abbreviations listed in table 1. 
Nitrate

Nitrate $^{3}$ concentrations in streams sampled in Phase II ranged from 0.060 to $3.48 \mathrm{mg} / \mathrm{L}$, with an overall median of $0.560 \mathrm{mg} / \mathrm{L}$. At the Milwaukee River sites, median concentrations were greater than the USEPA proposed criterion of $0.94 \mathrm{mg} / \mathrm{L}$ for nitrate in Level III Ecoregion 53 (table 13)(U.S. Environmental Protection Agency, 2000): Milwaukee River near Cedarburg $(1.40 \mathrm{mg} / \mathrm{L})$ and Milwaukee River at Milwaukee $(1.17 \mathrm{mg} / \mathrm{L})$. The remaining medians ranged from 0.270 to $0.860 \mathrm{mg} / \mathrm{L}$. The maximum nitrate concentration, $3.48 \mathrm{mg} / \mathrm{L}$, was measured at Honey Creek during the snowmelt sampling in March 2004 (fig. 14). Land use did not correlate appreciably with nitrate concentrations.

The median concentration of nitrate in stream samples was notably higher during high flow $(0.950 \mathrm{mg} / \mathrm{L})$ than during low flow $(0.480 \mathrm{mg} / \mathrm{L})$ (fig. 15A-C). Median concentrations in spring $(0.870 \mathrm{mg} / \mathrm{L})$ and winter $(1.10$ $\mathrm{mg} / \mathrm{L}$ ) were higher than those in summer and autumn and also were more variable. The spring high-flow median $(1.03 \mathrm{mg} / \mathrm{L})$ was higher than the spring low-flow median $(0.700 \mathrm{mg} / \mathrm{L})$; however, concentrations were highly variable at both extremes of flow. The winter high-flow median $(1.14 \mathrm{mg} / \mathrm{L})$ was higher than the winter low-flow median $(0.930 \mathrm{mg} / \mathrm{L})$; however, the variability in winter low-flow was greater than in winter high-flow.

\footnotetext{
${ }^{3}$ Because nitrite generally makes up a negligible proportion of nitrite plus nitrate in stream water, this combined constituent is referred to simply as "nitrate" in this report. Concentrations are reported as nitrogen $(\mathrm{N})$.
}

Data were available for Phase I and Phase II nitrate concentration comparisons at 12 sites (appendix 5). At five sites, median nitrate concentrations increased from Phase I to Phase II; the most notable differences were at Underwood Creek (which had no concentrations above the reporting level $(0.02 \mathrm{mg} / \mathrm{L}$ as $\mathrm{N})$ in the five samples summarized for Phase I and a median concentration of $0.410 \mathrm{mg} / \mathrm{L}$ in samples collected for Phase II) and Little Menomonee River (5,350 percent difference). Percent differences among the remaining three sites that indicated notable increases ranged from 256 percent at Honey Creek to 735 percent at Jewel Creek. Only two sites had notable decreases in nitrate concentrations: Menomonee River at Menomonee Falls (-42 percent) and Lincoln Creek (-41 percent)(fig. 16). The remaining five sites indicated no notable change.

Nitrate concentrations in harbor samples ranged from 0.180 to $1.95 \mathrm{mg} / \mathrm{L}$. The overall median concentration for harbor samples $(0.360 \mathrm{mg} / \mathrm{L})$ was lower than that for stream samples $(0.560 \mathrm{mg} / \mathrm{L})$. Inner-harbor sites had higher median concentrations $(0.400-0.490 \mathrm{mg} / \mathrm{L})$ than outer-harbor sites did (0.240-0.260 mg/L). Spring harbor samples had the highest median concentration $(0.490 \mathrm{mg} /$ L) and the most variability (fig. 15D). 


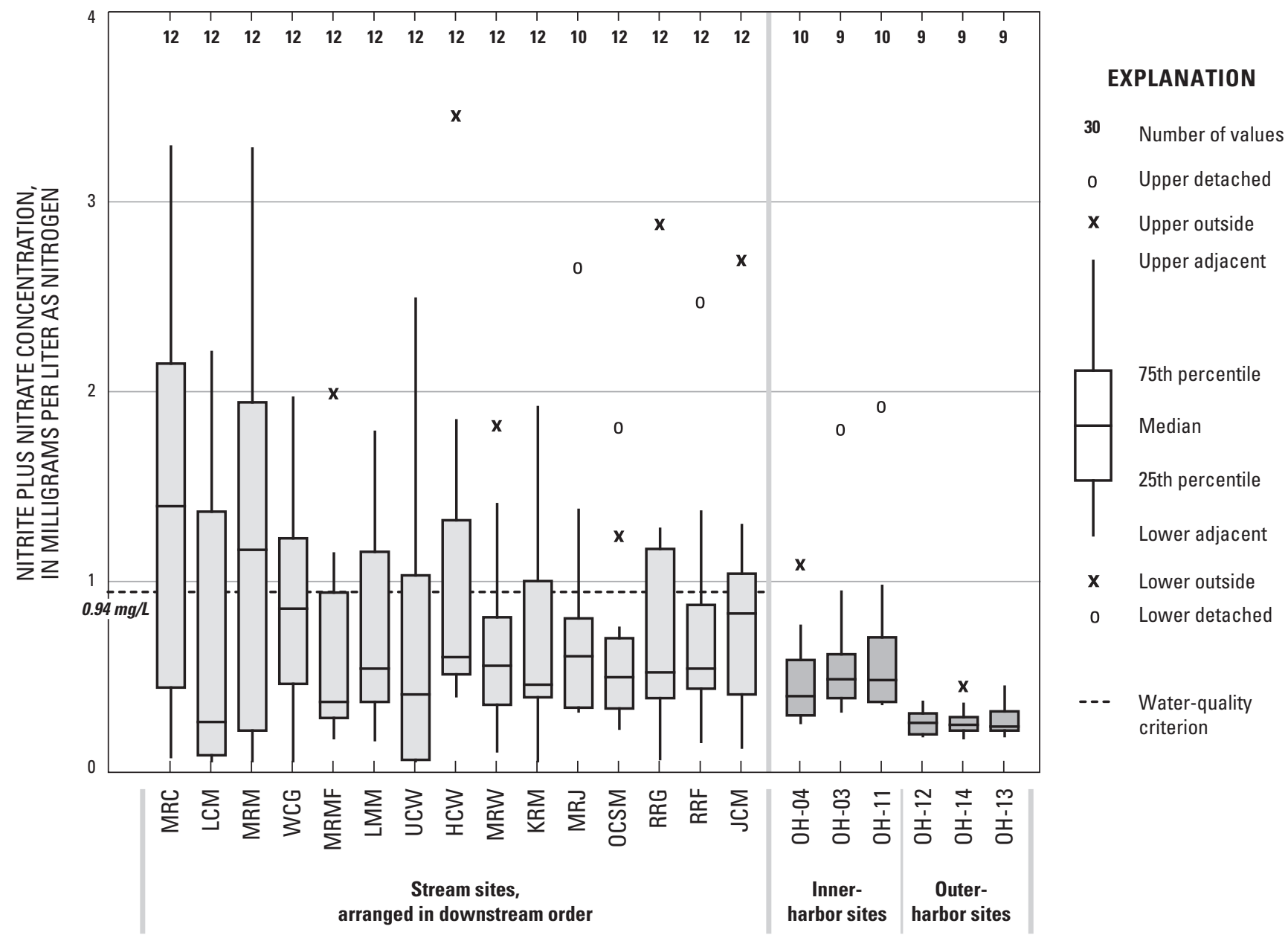

Figure 14. Distribution of nitrate concentrations, by site, in the Milwaukee Metropolitan Sewerage District planning area, Wis. Water-quality criterion line represents the U.S. Environmental Protection Agency proposed nutrient criterion for nitrate in Level III Ecoregion 53 streams (0.94 mg/L) (U.S. Environmental Protection Agency, 2000). Site abbreviations listed in table 1. 


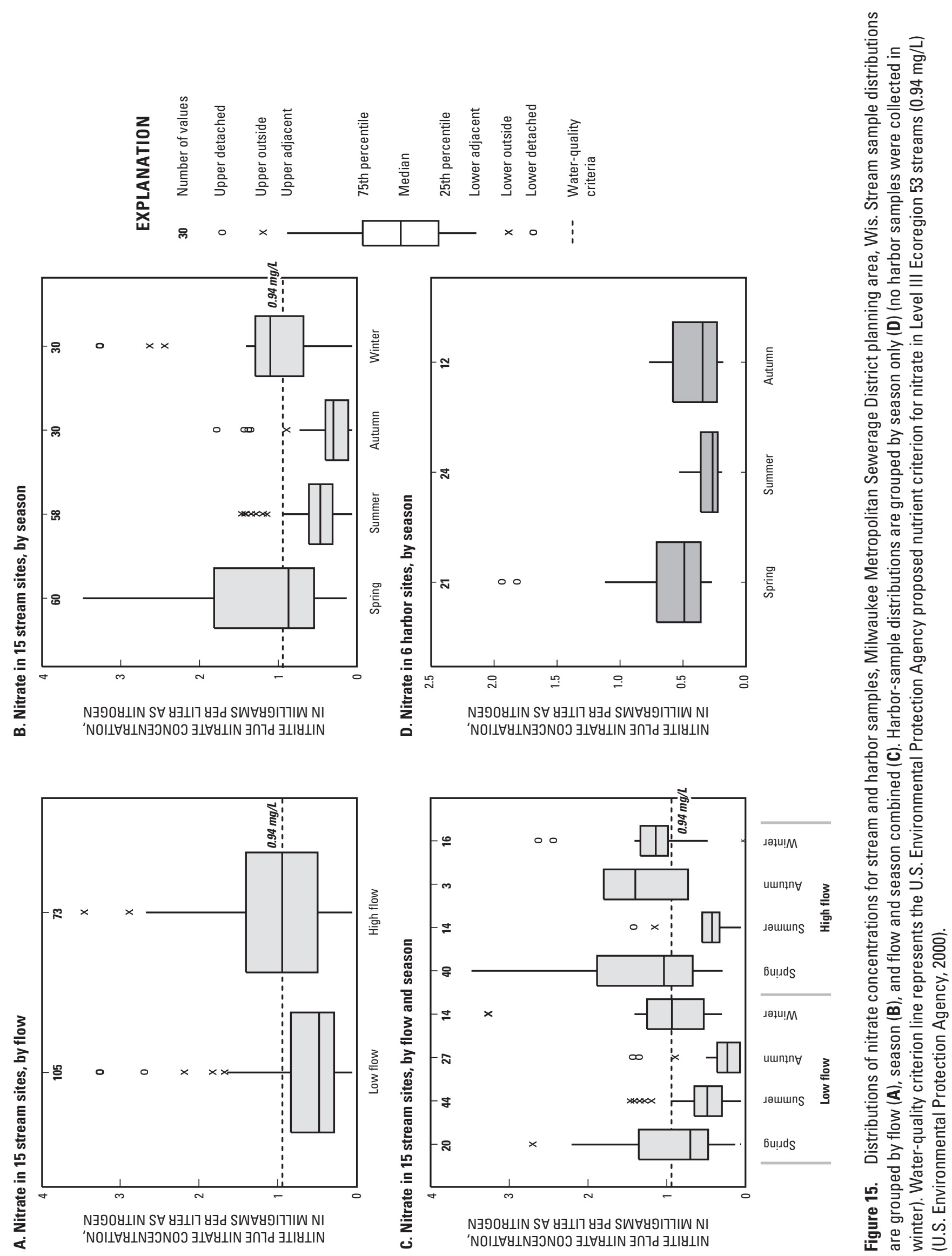




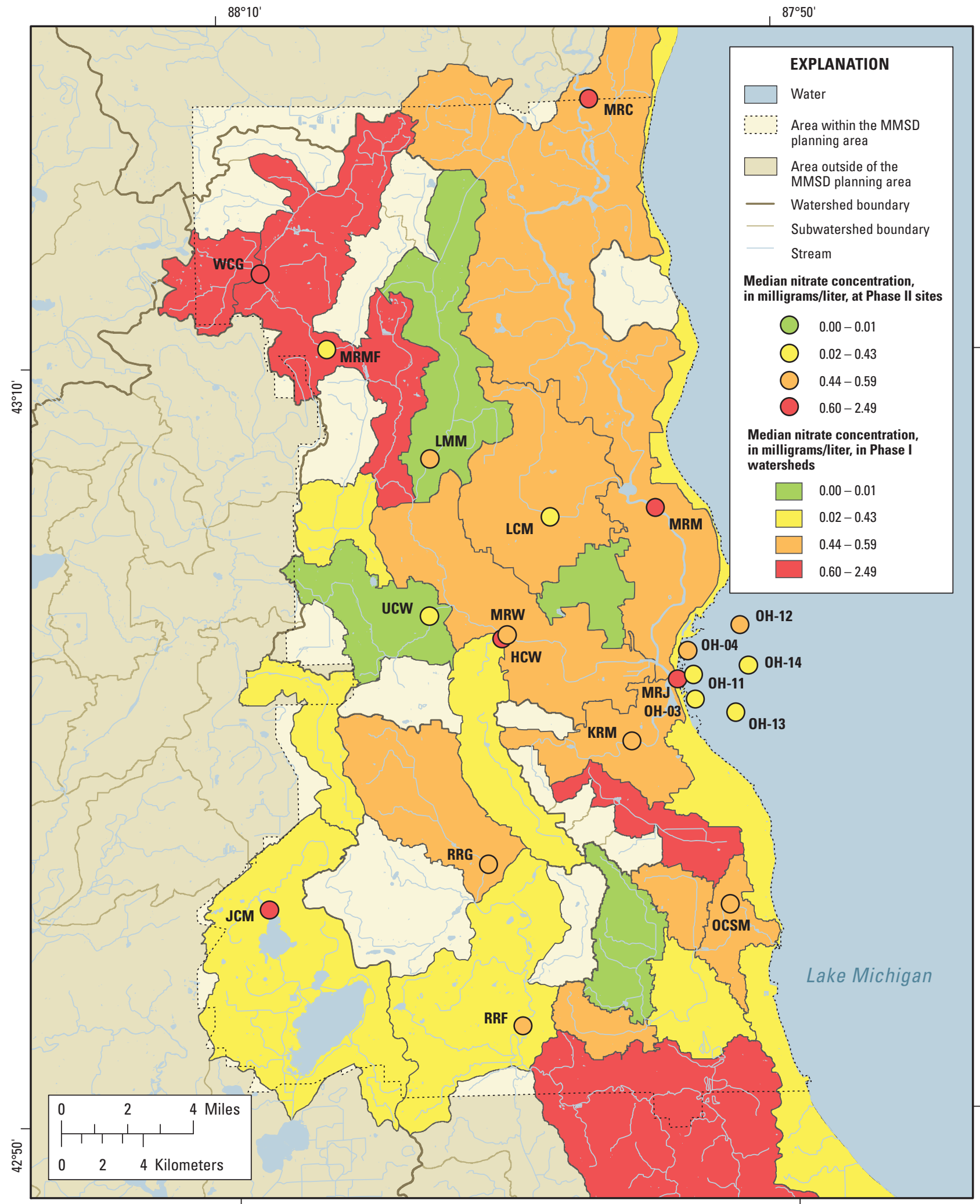

Base composited from Southeastern Wisconsin Regional Planning Commission regional base map, 1:2,000, 1995; U.S. Geological Survey digital line graph hydrography, 1:100,000, 1989; Wisconsin Department of Natural Resources version 2 hydrography, 1:24,000, 2002. Wisconsin Transverse Mercator Projection, referenced to North American Datum of 1983, 1991 adjustment.

Figure 16. Phase I and Phase II comparison of median nitrate concentrations in the Milwaukee Metropolitan Sewerage District (MMSD) planning area, Wis. Phase I values are shown by subwatershed values and quartiles, Phase II values are shown by site using same quartile. Site abbreviations listed in table 1. 


\section{Total Phosphorus}

Total phosphorus concentrations in Phase II streams ranged from 0.009 to $0.500 \mathrm{mg} / \mathrm{L}$; the overall median was $0.111 \mathrm{mg} / \mathrm{L}$, which is above the USEPA proposed criterion of $0.08 \mathrm{mg} / \mathrm{L}$ for total phosphorus in Level III Ecoregion 53 (table 13)(U.S. Environmental Protection Agency, 2000). Of the 15 stream sites, 11 had median concentrations greater than the USEPA criterion: Lincoln Creek (0.163 mg/L), Little Menomonee River (0.152 mg/L), Honey Creek (0.150 mg/L), Kinnickinnic River (0.148 $\mathrm{mg} / \mathrm{L})$, Milwaukee River at Milwaukee $(0.133 \mathrm{mg} / \mathrm{L})$, Milwaukee River near Cedarburg $(0.120 \mathrm{mg} / \mathrm{L})$, Menomonee River at Wauwatosa $(0.113 \mathrm{mg} / \mathrm{L})$, Root River at Grange Avenue $(0.113 \mathrm{mg} / \mathrm{L})$, Menomonee River at Menomonee Falls $(0.100 \mathrm{mg} / \mathrm{L})$, Root River near Franklin (0.092 $\mathrm{mg} / \mathrm{L})$, and Underwood Creek (0.085 mg/L). Medians for the remaining four sites ranged from 0.062 to $0.079 \mathrm{mg} / \mathrm{L}$, all of which were above the reference concentration of $0.03-0.04 \mathrm{mg} / \mathrm{L}$ proposed by Robertson and others (2006). The maximum total phosphorus concentration, $0.500 \mathrm{mg} /$ L, was measured in Lincoln Creek (fig. 17). Land use did not correlate appreciably with total phosphorus.
The median total phosphorus concentration during high flow $(0.136 \mathrm{mg} / \mathrm{L})$ was higher than that during low flow $(0.098 \mathrm{mg} / \mathrm{L})($ fig. $18 \mathrm{~A}-\mathrm{C})$. Variability with respect to season was not observed. When flow and season were looked at together, no further patterns were observed.

Data were available for Phase I and Phase II total phosphorus concentration comparisons at 11 sites (appendix 5). At six sites, median total phosphorus concentrations increased from Phase I to Phase II. Percent differences ranged from 32 percent at Oak Creek to 1,420 percent at Little Menomonee River (fig. 19). The remaining five sites indicated no notable differences.

Total phosphorus concentrations at harbor sites ranged from 0.002 to $0.095 \mathrm{mg} / \mathrm{L}$. The overall median concentration for harbor samples $(0.021 \mathrm{mg} / \mathrm{L})$ was lower than that for stream samples $(0.111 \mathrm{mg} / \mathrm{L})$, and is within the range of concentrations indicative of mesotrophic lake conditions (0.012-0.024 mg/L)(Carlson, 1977). Concentrations at inner-harbor sites were indicative of eutrophic conditions and had higher median concentrations $(0.032-$ $0.048 \mathrm{mg} / \mathrm{L}$ ) than did outer-harbor sites, where median concentrations were close to the reporting level for total phosphorus $(0.004 \mathrm{mg} / \mathrm{L})$, and were indicative of oligotrophic conditions (fig. 17). Spring harbor samples had the highest median concentration $(0.028 \mathrm{mg} / \mathrm{L})$ and indicated the greatest variability (fig. 18D). 


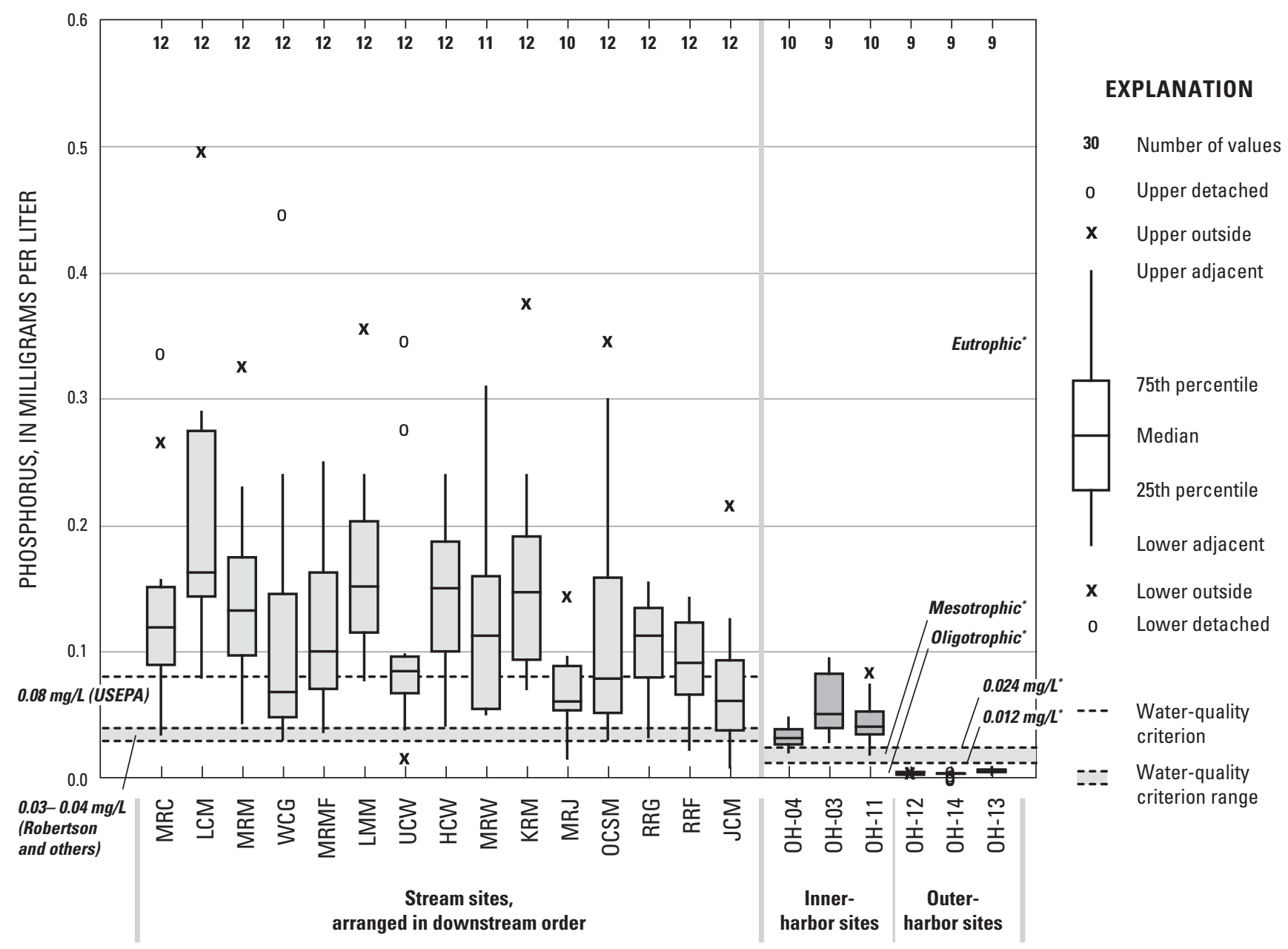

Figure 17. Distribution of total phosphorus concentrations, by site, in the Milwaukee Metropolitan Sewerage District planning area, Wis. Stream water-quality criterion lines represent the U.S. Environmental Protection Agency proposed nutrient criterion for total phosphorus in Level III Ecoregion 53 streams $(0.08 \mathrm{mg} / \mathrm{L})(\mathrm{U} . S$. Environmental Protection Agency, 2000) and the reference concentrations for wadeable Wisconsin streams $(0.03-0.04 \mathrm{mg} / \mathrm{L})$ as defined by Robertson and others (2006). Labels for harbor trophic class boundaries $(0.012 \mathrm{mg} / \mathrm{L}$ and $0.024 \mathrm{mg} / \mathrm{L})$ are marked with an asterisk $(*)$; boundaries delineate trophic classes (oligotrophic, mesotropic, eutrophic) for lakes as defined by Carlson (1977). Site abbreviations listed in table 1. 

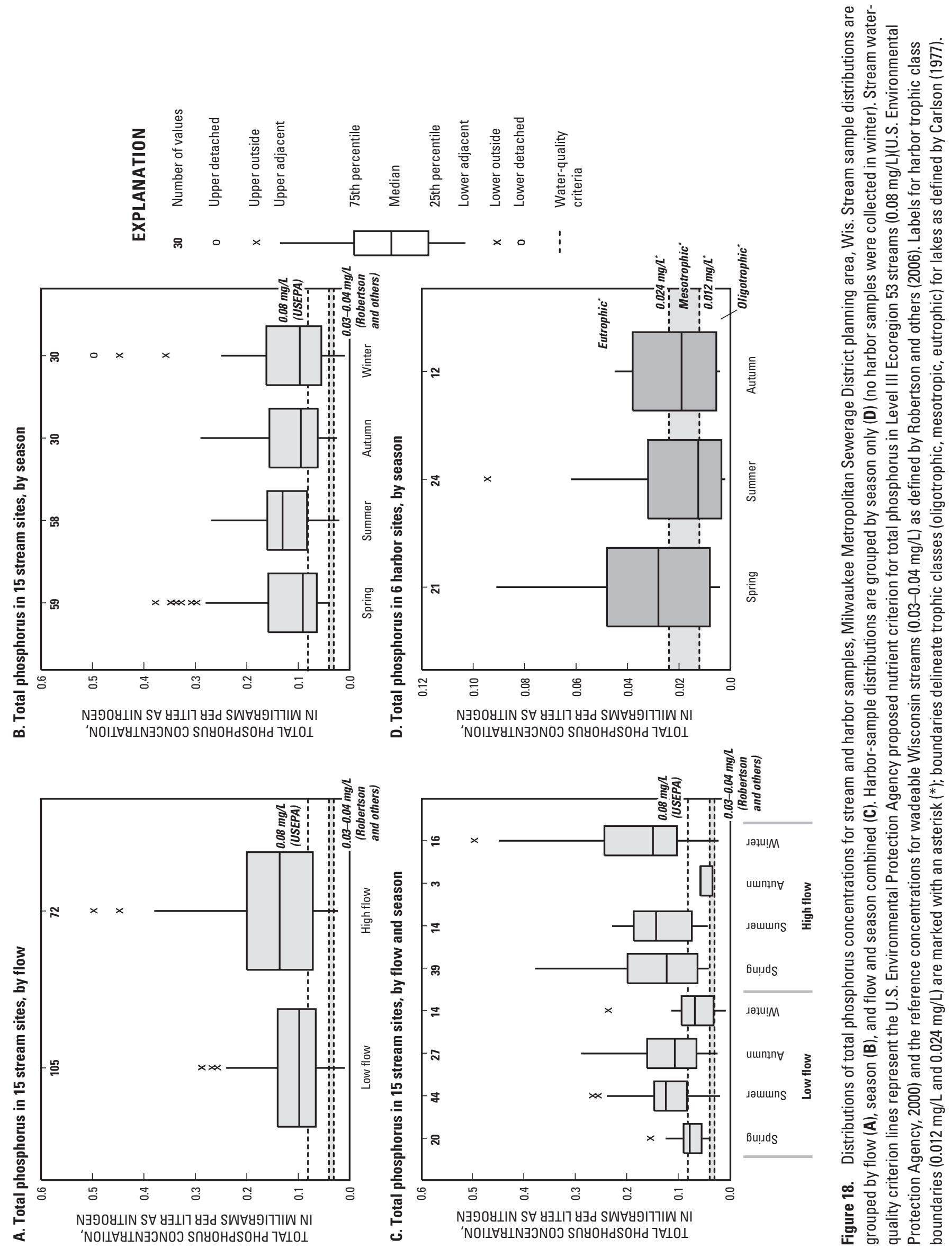


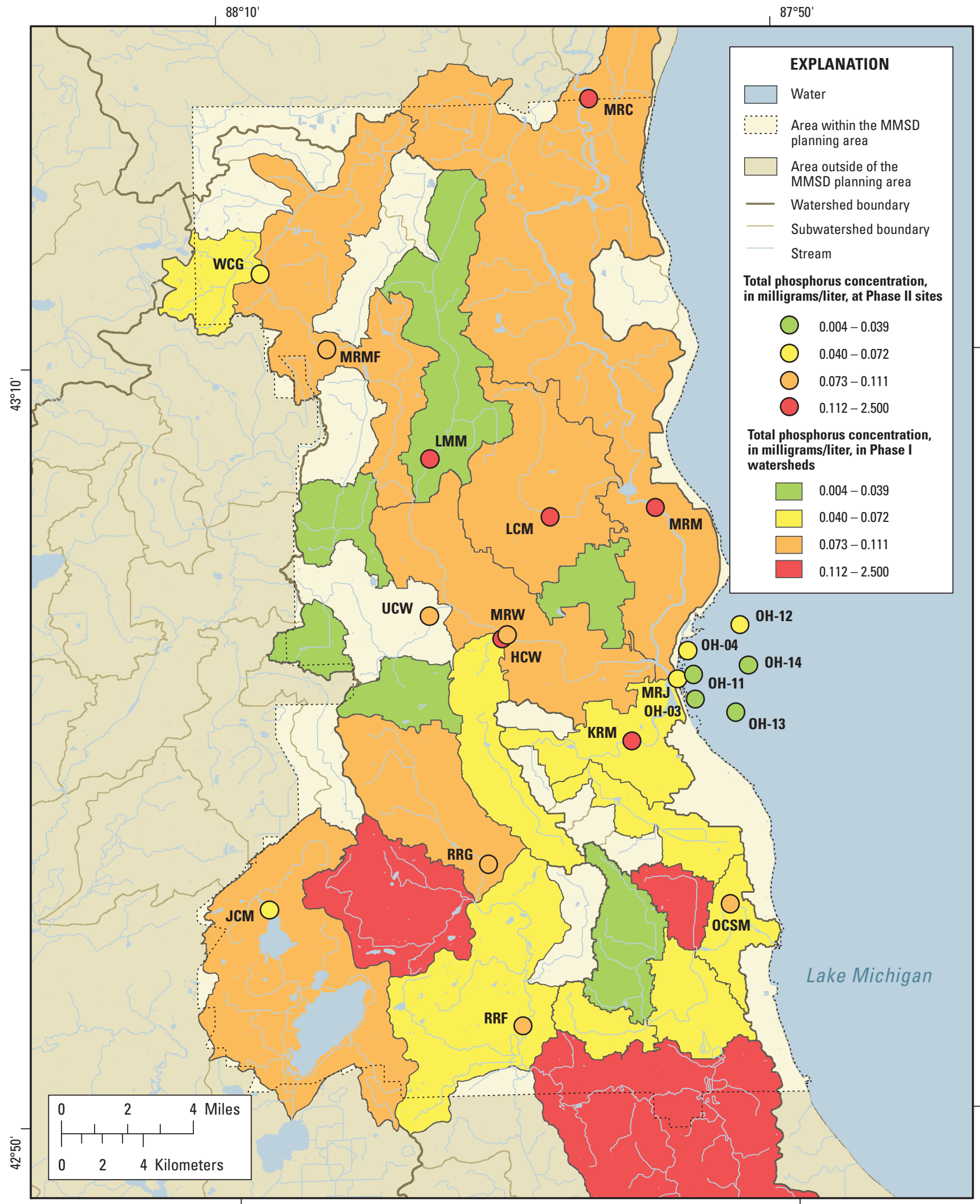

Base composited from Southeastern Wisconsin Regional Planning Commission regional base map, 1:2,000, 1995; U.S. Geological Survey digital line graph hydrography, 1:100,000, 1989; Wisconsin Department of Natural Resources version 2 hydrography, 1:24,000, 2002. Wisconsin Transverse Mercator Projection, referenced to North American Datum of 1983, 1991 adjustment.

Figure 19. Phase I and Phase II comparison of median total phosphorus concentrations in the Milwaukee Metropolitan Sewerage District (MMSD) planning area, Wis. Phase I values are shown by subwatershed values and quartiles, Phase II values are shown by site using same quartile. Site abbreviations listed in table 1 . 
Loads, Yields, and Volumetrically Weighted Concentrations of Total Phosphorus

Total phosphorus loads for June through September 2004 ranged from 4,980 $\mathrm{lb}$ at the Kinnickinnic River site to $98,200 \mathrm{lb}$ at the Milwaukee River at Milwaukee site (table 14). VW concentrations ranged from $0.15 \mathrm{mg} / \mathrm{L}$ at Milwaukee River near Cedarburg and Menomonee River at Wauwatosa to $0.27 \mathrm{mg} / \mathrm{L}$ at Kinnickinnic River at Milwaukee. In water year 2005, the total phosphorus load ranged from 8,840 lb at Kinnickinnic River to 113,000 lb at Milwaukee River at Milwaukee. VW concentrations ranged from $0.13 \mathrm{mg} / \mathrm{L}$ at Menomonee River at Wauwatosa to $0.26 \mathrm{mg} / \mathrm{L}$ at Kinnickinnic River.

Total phosphorus yields for the complete water year 2005 ranged from $144 \mathrm{lb} / \mathrm{mi}^{2}$ at Milwaukee River near Cedarburg to $470 \mathrm{lb} / \mathrm{mi}^{2}$ at Kinnickinnic River at (table 14). The median total phosphorus yield for rural watersheds in the Southeastern Wisconsin Till Plains Ecoregion was $283 \mathrm{lb} / \mathrm{mi}^{2}$, and the range was 40.7 to $1,800 \mathrm{lb} / \mathrm{mi}^{2}$ (Corsi and others, 1997). Within the two predominantly rural drainage basins, the Milwaukee River near Cedarburg and the Milwaukee River at Milwaukee sites had total phosphorus yields of $144 \mathrm{lb} / \mathrm{mi}^{2}$ and $162 \mathrm{lb} / \mathrm{mi}^{2}$, respectively. These yields were less than the median, but within the range of total phosphorus yields measured in the Ecoregion (Corsi and others, 1997). The median total phosphorus yield for urban watersheds in the Southeast Wisconsin Till Plains Ecoregion was $318 \mathrm{lb} / \mathrm{mi}^{2}$, and the range was 133 to $1,210 \mathrm{lb} / \mathrm{mi}^{2}$ (Corsi and others, 1997). The Kinnickinnic River drainage basin had a yield of 470 $\mathrm{lb} / \mathrm{mi}^{2}$, which was greater than the median yield in the Ecoregion. The total phosphorus yield for the Menomonee River drainage basin was less than yields at similar urban sites but within the range of monitored yields.

Total phosphorus loads indicated a seasonal pattern at Milwaukee River near Cedarburg and Milwaukee River at Milwaukee in water year 2005, with higher loads generally being recorded February through May (table 15). No seasonal response in loads was observed at Menomonee River at Wauwatosa and Kinnickinnic River during water year 2005. The greatest monthly loads of total phosphorus for data collected in 2004 were recorded in June at all sites except Kinnickinnic River, where greatest monthly loads were recorded in August.

\section{Chlorophyll a}

Chlorophyll $a$ concentrations in Phase II streams ranged from 0.260 to $170 \mu \mathrm{g} / \mathrm{L}$; the median was $5.79 \mu \mathrm{g} / \mathrm{L}$, which is at the USEPA proposed criterion for cholorophyll a in Nutrient Ecoregion VII (table 13)(U.S. Environmental Protection Agency, 2000). Median concentrations were greater than the USEPA criterion at the following seven sites: Milwaukee River near Cedarburg (13.4 $\mu \mathrm{g} / \mathrm{L})$, Jewel Creek (10.3 $\mu \mathrm{g} / \mathrm{L})$, Milwaukee River at Milwaukee (10.2 $\mu \mathrm{g} / \mathrm{L})$, Menomonee River at Menomonee Falls (8.45 $\mu \mathrm{g} / \mathrm{L})$, Menomonee River at Wauwatosa $(7.80 \mu \mathrm{g} / \mathrm{L})$,

Table 14. Annual total phosphorus load and yield, average daily phosphorus yield, total water flow, and volumetric total phosphorus concentrations for four Phase II sites in the Milwaukee Metropolitan Sewerage District planning area, Wis.

[lbs, pounds; $1 \mathrm{~b} / \mathrm{mi}^{2}$, pound per square mile; $1 \mathrm{~b} / \mathrm{mi}^{2} / \mathrm{d}$, pound per square mile per day; $\mathrm{ft}^{3} / \mathrm{s}$, cubic foot per second; $\mathrm{mg} / \mathrm{L}$, milligram per liter; values in bold are for complete water years]

\begin{tabular}{|c|c|c|c|c|c|c|}
\hline $\begin{array}{l}\text { Water } \\
\text { year }\end{array}$ & $\begin{array}{l}\text { Months } \\
\text { sampled }\end{array}$ & $\begin{array}{c}\text { Total } \\
\text { phosphorus load } \\
\text { (Ibs) }\end{array}$ & $\begin{array}{c}\text { Total } \\
\text { phosphorus yield } \\
\left(\mathrm{lb} / \mathrm{mi}^{2}\right)\end{array}$ & $\begin{array}{c}\text { Average daily } \\
\text { phosphorus yield } \\
\left(\mathrm{lb} / \mathrm{mi}^{2} / \mathrm{d}\right)\end{array}$ & $\begin{array}{c}\text { Total } \\
\text { water flow } \\
\left(\mathrm{ft}^{3} / \mathrm{s}\right) \\
\end{array}$ & $\begin{array}{c}\text { Volumetric total } \\
\text { phosphorus concentration } \\
\text { (mg/L) }\end{array}$ \\
\hline \multicolumn{7}{|c|}{ Milwaukee River near Cedarburg } \\
\hline 2004 & June-Sept. & 81,800 & 135 & 1.10 & 98,100 & 0.15 \\
\hline 2005 & Oct.-Sept. & 87,500 & 144 & .40 & 114,000 & .14 \\
\hline \multicolumn{7}{|c|}{ Milwaukee River at Milwaukee } \\
\hline 2004 & June-Sept. & 98,200 & 141 & 1.16 & 114,000 & .16 \\
\hline 2005 & Oct.-Sept. & 113,000 & 162 & .44 & 132,000 & .16 \\
\hline \multicolumn{7}{|c|}{ Menomonee River at Wauwatosa } \\
\hline 2004 & June-Sept. & 11,000 & 89.4 & .73 & 13,300 & .15 \\
\hline 2005 & Oct.-Sept. & 18,700 & 152 & .42 & 26,600 & .13 \\
\hline \multicolumn{7}{|c|}{ Kinnickinnic River at S. 11th Street at Milwaukee } \\
\hline 2004 & June-Sept. & 4,980 & 264 & 2.17 & 3,370 & .27 \\
\hline 2005 & Oct.-Sept. & 8,840 & 470 & 1.29 & 6,320 & .26 \\
\hline
\end{tabular}


Table 15. Monthly and annual total phosphorus loads for four Phase II sites in the Milwaukee Metropolitan Sewerage District planning area, Wis., for water years 2004 and 2005.

[WY, water year]

\begin{tabular}{|c|c|c|c|c|}
\hline \multirow[b]{2}{*}{ Month } & \multicolumn{4}{|c|}{ Total phosphorus (pounds) } \\
\hline & $\begin{array}{l}\text { Milwaukee River } \\
\text { near Cedarburg }\end{array}$ & $\begin{array}{c}\text { Milwaukee River } \\
\text { at Milwaukee }\end{array}$ & $\begin{array}{c}\text { Menomonee River } \\
\text { at Wauwatosa }\end{array}$ & $\begin{array}{c}\text { Kinnickinnic River } \\
\text { at S. 11th Street } \\
\text { at Milwaukee }\end{array}$ \\
\hline \multicolumn{5}{|c|}{ Water year 2004} \\
\hline June & 60,800 & 73,100 & 5,190 & 1,440 \\
\hline July & 13,700 & 13,500 & 3,690 & 1,700 \\
\hline August & 5,600 & 8,420 & 1,840 & 1,730 \\
\hline September & 1,690 & 3,170 & 239 & 102 \\
\hline WY total & 81,800 & 98,200 & 11,000 & 4,980 \\
\hline \multicolumn{5}{|c|}{ Water year 2005} \\
\hline October & 1,010 & 2,620 & 523 & 357 \\
\hline November & 1,980 & 3,160 & 672 & 464 \\
\hline December & 11,100 & 8,110 & 587 & 384 \\
\hline January & 3,890 & 7,430 & 2,270 & 1,250 \\
\hline February & 17,700 & 26,600 & 2,540 & 956 \\
\hline March & 23,300 & 24,800 & 2,400 & 739 \\
\hline April & 10,000 & 13,400 & 1,460 & 714 \\
\hline May & 6,130 & 12,300 & 2,200 & 818 \\
\hline June & 3,270 & 4,530 & 1,440 & 497 \\
\hline July & 3,840 & 4,720 & 1,580 & 772 \\
\hline August & 2,940 & 2,460 & 822 & 389 \\
\hline September & 2,370 & 2,640 & 2,190 & 1,500 \\
\hline WY total & 87,500 & 113,000 & 18,700 & 8,840 \\
\hline
\end{tabular}

Honey Creek (6.76 $\mu \mathrm{g} / \mathrm{L})$, and Little Menomonee River $(5.96 \mu \mathrm{g} / \mathrm{L})$. At the remaining sites, median concentrations ranged from 1.34 to $5.34 \mu \mathrm{g} / \mathrm{L}$, all of which were above the reference condition of $1.0 \mu \mathrm{g} / \mathrm{L}$ proposed by Robertson and others (2006). The maximum chlorophyll $a$ concentration, $170 \mu \mathrm{g} / \mathrm{L}$, was measured in Underwood Creek (fig. 20). Land use did not correlate appreciably with chlorophyll $a$.

The median concentration of chlorophyll $a$ in stream samples during high flow $(7.98 \mu \mathrm{g} / \mathrm{L})$ was higher than during low flow $(4.96 \mu \mathrm{g} / \mathrm{L})$. The highest median concentration $(10.7 \mu \mathrm{g} / \mathrm{L})$ was observed in spring samples; these samples also indicated the greatest variability in concentrations. The summer high-flow median $(7.50 \mu \mathrm{g} / \mathrm{L})$ was higher than the summer low-flow median $(4.62 \mu \mathrm{g} / \mathrm{L})$, whereas spring high- and low-flow medians were similar (11.6 and $9.98 \mu \mathrm{g} / \mathrm{L}$, respectively)(fig. 21A-C).

Data were available for Phase I and Phase II chlorophyll $a$ concentration comparisons at seven sites (appendix 5). Two notable increases were observed at Menomonee
River at Menomonee Falls (49 percent difference) and Menomonee River at Wauwatosa (30 percent difference), whereas one notable decrease was observed at Root River near Franklin (-34 percent difference). The remaining four sites indicated no notable differences.

Chlorophyll $a$ concentrations in harbor samples ranged from 0.260 to $31.5 \mu \mathrm{g} / \mathrm{L}$. The overall median for harbor samples $(1.82 \mu \mathrm{g} / \mathrm{L})$ was lower than that for stream samples $(5.79 \mu \mathrm{g} / \mathrm{L})$; in addition, it was less than the range of concentrations indicative of mesotrophic lake conditions (2.60-7.20 $\mu \mathrm{g} / \mathrm{L})$ and were therefore indicative of oligotrophic conditions (Carlson, 1977). Concentrations at innerharbor sites were indicative of mesotrophic conditions and had higher median concentrations $(4.38-5.70 \mu \mathrm{g} / \mathrm{L})$ than outer-harbor sites (0.830-1.09 $\mu \mathrm{g} / \mathrm{L})$, where median concentrations were indicative of oligotrophic conditions. Summer harbor samples had the highest median concentration $(3.35 \mu \mathrm{g} / \mathrm{L})$ and indicated the most variability (fig. 21D). 


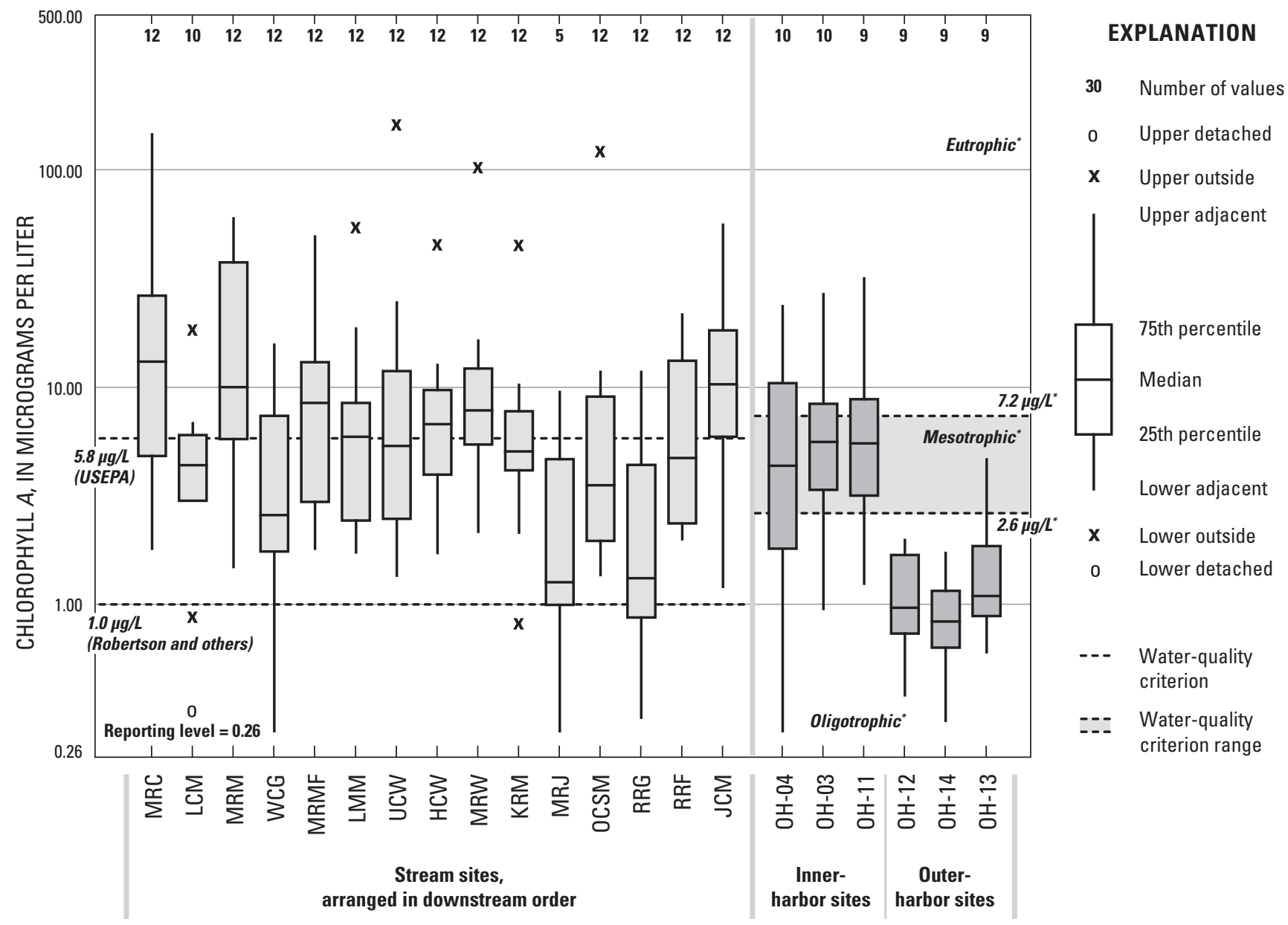

Figure 20. Distribution of chlorophyll a concentrations, by site, in the Milwaukee Metropolitan Sewerage District planning area, Wis. Stream water-quality criterion lines represent the U.S. Environmental Protection Agency proposed nutrient criterion for chlorophyll $a$ in Nutrient Ecoregion VII $(5.8 \mu \mathrm{g} / \mathrm{L})($ U.S. Environmental Protection Agency, 2000) and the reference concentration for wadeable Wisconsin streams $(1.0 \mu \mathrm{g} / \mathrm{L})$ as defined by Robertson and others (2006). Labels for harbor trophic class boundaries $(2.6$ $\mu \mathrm{g} / \mathrm{L}$ and $7.2 \mu \mathrm{g} / \mathrm{L}$ ) are marked with an asterisk (*); boundaries delineate trophic classes (oligotrophic, mesotropic, eutrophic) for lakes as defined by Carlson (1977). Site abbreviations listed in table 1. 

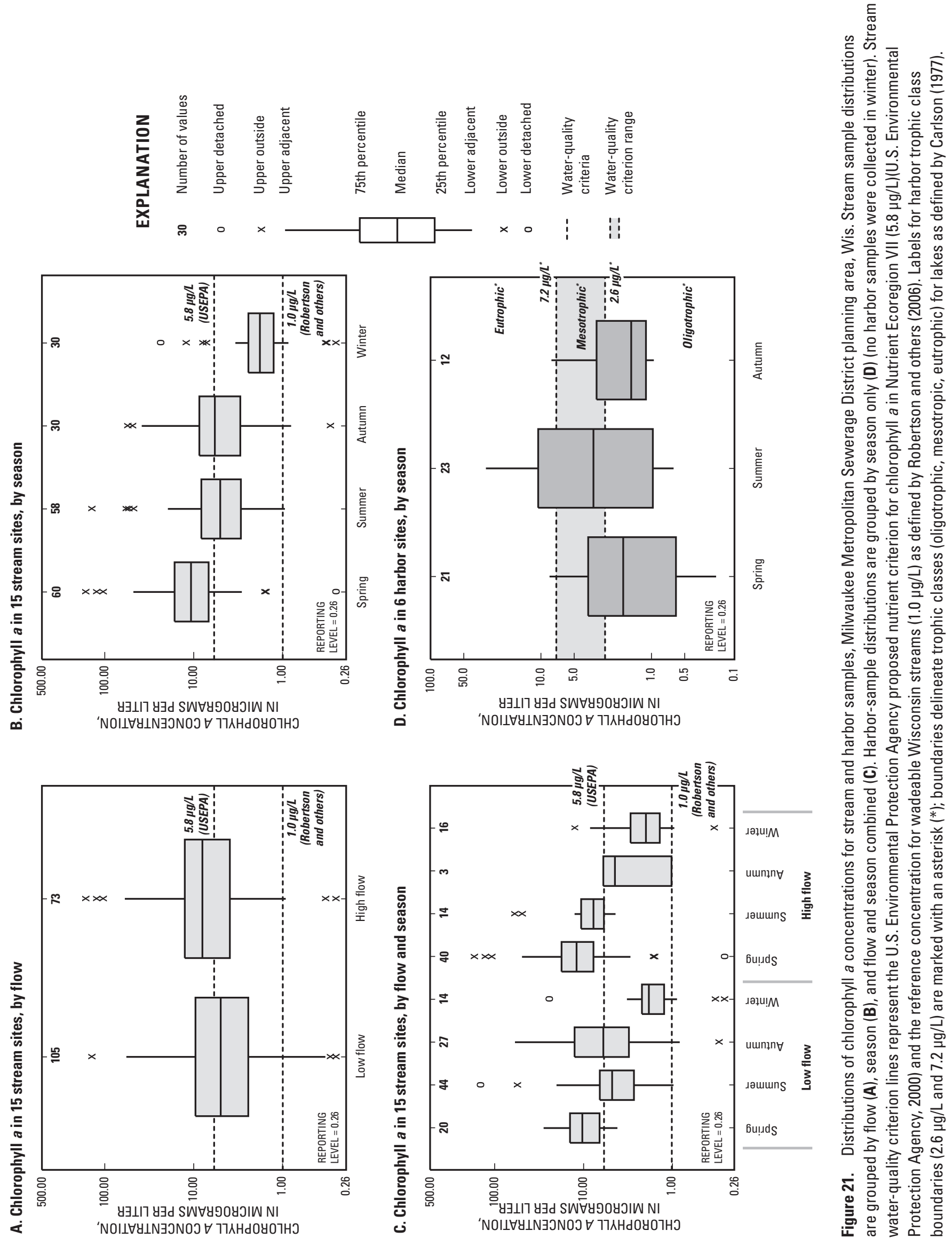



क्ञ

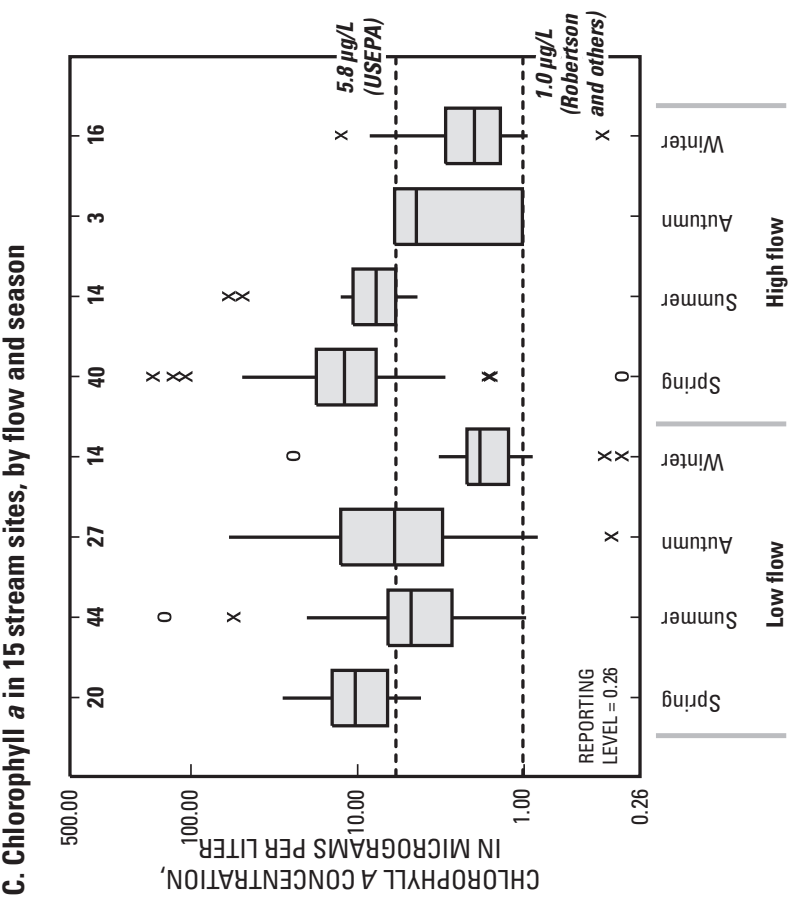

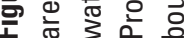




\section{Suspended Sediment}

Suspended-sediment concentrations at Phase II stream sites ranged from 1 to $273 \mathrm{mg} / \mathrm{L}$, with a median of $15 \mathrm{mg} / \mathrm{L}$. Jewel Creek had the highest median concentration $(28 \mathrm{mg} / \mathrm{L})$; at the remaining sites, the median ranged from 4.0 to $25.5 \mathrm{mg} / \mathrm{L}$. The maximum suspended-sediment concentration, $273 \mathrm{mg} / \mathrm{L}$, was measured in Oak Creek (fig. 22). Variations in land use did not correlate appreciably with differences in suspended-sediment concentrations.

The median suspended-sediment concentration during high flow $(26 \mathrm{mg} / \mathrm{L})$ was higher than that during low flow (9 mg/L). Spring had the highest median concentration (20.5 mg/L); variability was similar among all seasons. The highest median concentration $(39 \mathrm{mg} / \mathrm{L})$ was observed during spring high flow (fig. 23A-C).
Data were available for Phase I and Phase II suspended-sediment concentration comparisons at 11 sites (appendix 5). Suspended-sediment concentrations decreased from Phase I to Phase II at all sites, with percent differences ranging from -28 to -97 percent. The greatest decreases were observed at Kinnickinnic River (-97 percent), Underwood Creek (-97 percent), Honey Creek (-95 percent), and Root River at Grange Avenue (-93 percent).

Median suspended-sediment concentrations for harbor samples ranged from 1 to $45 \mathrm{mg} / \mathrm{L}$. The overall median for harbor samples $(2 \mathrm{mg} / \mathrm{L})$ was lower than that for stream samples $(15 \mathrm{mg} / \mathrm{L})$. Inner-harbor sites had higher median concentrations $(2-6.5 \mathrm{mg} / \mathrm{L})$ than outer-harbor sites $(1-2$ $\mathrm{mg} / \mathrm{L})$. Harbor samples had the highest median concentration and greatest variability during spring $(3.5 \mathrm{mg} / \mathrm{L})$ (fig. 23D).

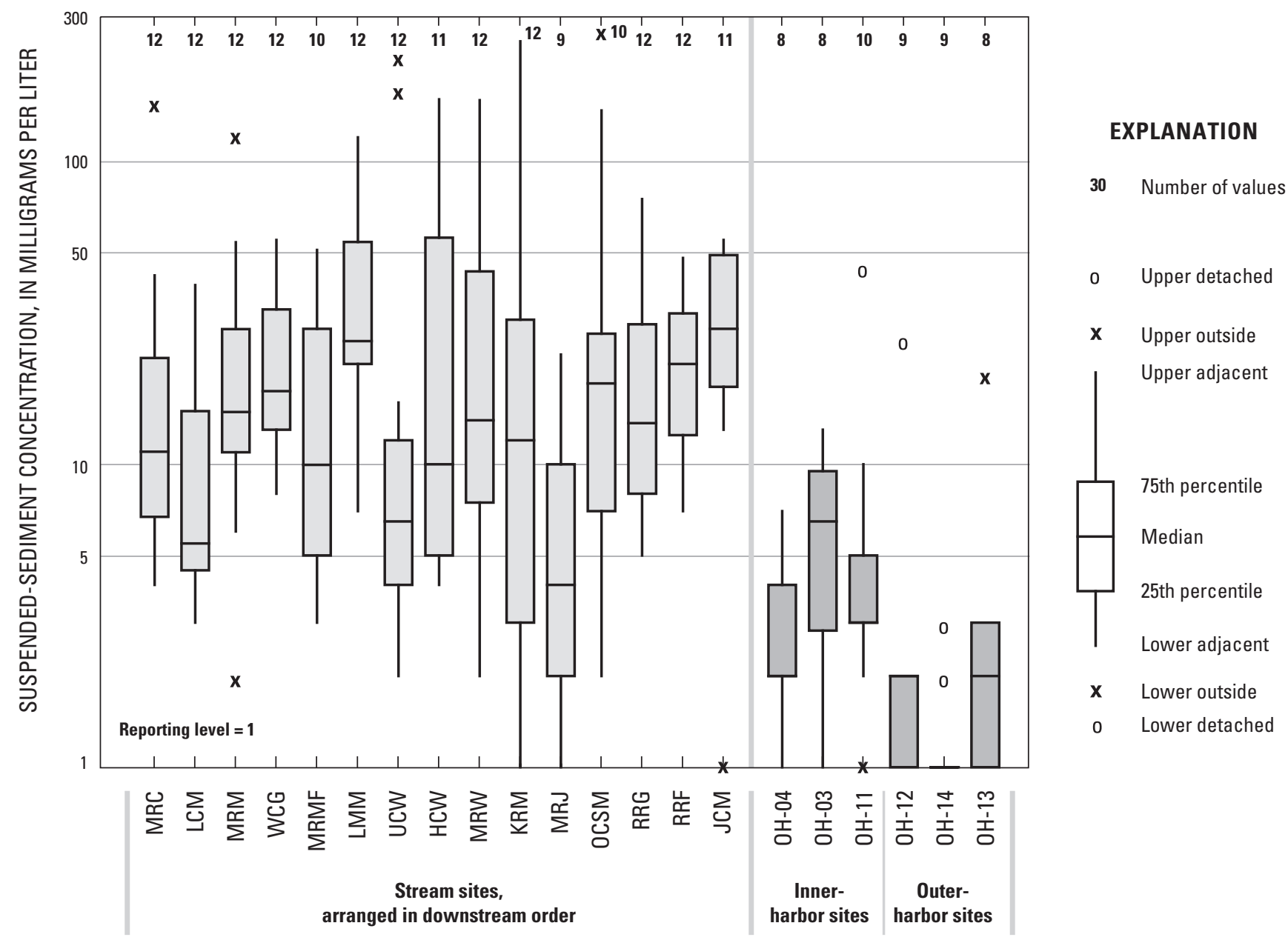

Figure 22. Distribution of suspended-sediment concentrations, by site, in the Milwaukee Metropolitan Sewerage District planning area, Wis. Site abbreviations listed in table 1. 

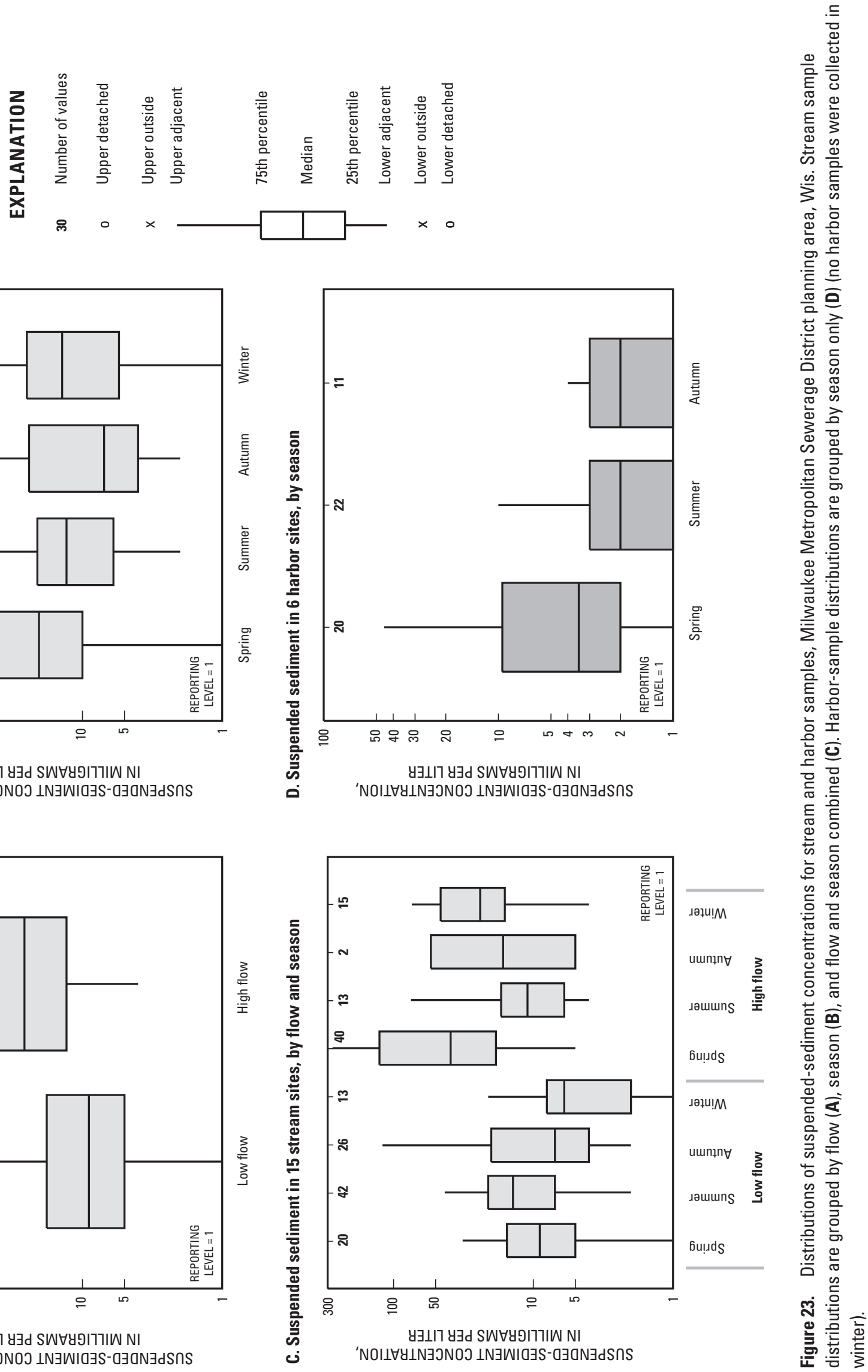
Loads, Yields, and Volumetrically Weighted Concentrations of Suspended Sediment

Suspended-sediment loads for June through September 2004 ranged from 2,060 tons at Kinnickinnic River to 9,380 tons at Milwaukee River at Milwaukee (table 16). VW suspended-sediment concentrations ranged from 28 $\mathrm{mg} / \mathrm{L}$ at Milwaukee River near Cedarburg to $227 \mathrm{mg} / \mathrm{L}$ at Kinnickinnic River. In water year 2005, the suspendedsediment load ranged from 2,380 tons at Kinnickinnic River to 8,340 tons at Milwaukee River near Cedarburg. VW suspended-sediment concentrations ranged from 23 $\mathrm{mg} / \mathrm{L}$ at Milwaukee River at Milwaukee to $140 \mathrm{mg} / \mathrm{L}$ at Kinnickinnic River.

Combined averages of average daily sediment yields from June through September 2004 and water year 2005 were compared to combined average yields from available historical data. Menomonee River at Wauwatosa indicated the largest decrease, with average yields decreasing 50 percent. Milwaukee River at Milwaukee and Kinnickinnic River indicated comparatively moderate decreases (36 and 29 percent, respectively). Milwaukee River near Cedarburg indicated no change in average daily sediment yields.

Yields from water year 2005 ranged from 11.9 tons $/ \mathrm{mi}^{2}$ at Milwaukee River at Milwaukee to 127 tons $/ \mathrm{mi}^{2}$ at Kinnickinnic River (table 16). The median yield for the Southern Wisconsin Till Plains Ecoregion for rural sites was 32.4 tons $/ \mathrm{mi}^{2}$, and the range was 4.4 to 1,710 tons $/ \mathrm{mi}^{2}$ (Corsi and others, 1997). Yields from the two predominantly rural drainage basins (Milwaukee River near Cedarburg and Milwaukee River at Milwaukee) are within this range but near the minimum yield. The median yield for urban sites in the Southern Wisconsin Till Plains Ecoregion ranged from 17 to 451 tons $/ \mathrm{mi}^{2}$, and the median was 130 tons $/ \mathrm{mi}^{2}$ (Corsi and others, 1997). Yields from the two predominantly urban drainage basins (Menomonee River at Wauwatosa and Kinnickinnic River) were 29.7 tons $/ \mathrm{mi}^{2}$ and 127 tons $/ \mathrm{mi}^{2}$, respectively (table 13 ). These yields were within the Ecoregion range for urban sites, with the Kinnickinnic River site close to the median.
VW sediment concentrations for averages of water years 2004 and 2005 ranged from $27 \mathrm{mg} / \mathrm{L}$ at Milwaukee River at Milwaukee to $184 \mathrm{mg} / \mathrm{L}$ at Kinnickinnic River (table 16). The sediment concentrations were within the range of sediment concentrations previously found at sites within the MMSD planning area (Schneider and others, 2004). When compared to combined averages of available historical data, Menomonee River at Wauwatosa had the greatest decrease in VW sediment concentration with a 55percent decrease. The next greatest decrease was observed at Milwaukee River at Milwaukee, with a 52-percent decrease. Decreases at Kinnickinnic River and Milwaukee River near Cedarburg were more moderate, with decreases of 25 and 26 percent, respectively.

Suspended-sediment loads indicated a seasonal pattern at Milwaukee River near Cedarburg and Milwaukee River at Milwaukee in water year 2005, with higher loads generally being recorded from February through May (table 17). A seasonal pattern was also observed at Menomonee River at Wauwatosa with generally elevated levels during these same months, and highest loads were recorded in January. No seasonal response in suspended sediment loads was observed at Kinnickinnic River during water year 2005. The greatest monthly loads of suspended sediment for data collected in 2004 were recorded in June at Milwaukee River near Cedarburg and Milwaukee River at Milwaukee, in July at Menomonee River at Wauwatosa, and in August at Kinnickinnic River. 
Table 16. Annual suspended-sediment load and yield, average daily sediment yield, total water flow, and volumetrically weighted sediment concentrations for four Phase II sites in the Milwaukee Metropolitan Sewerage District planning area, Wis.

[tons $/ \mathrm{mi}^{2}$, tons per square mile; tons $/ \mathrm{mi}^{2} / \mathrm{d}$, tons per square mile per day; $\mathrm{ft}^{3} / \mathrm{s}$, cubic foot per second; mg/L, milligram per liter; VW, volumetrically weighted; --, no data; values in bold are for complete water years]

\begin{tabular}{|c|c|c|c|c|c|c|}
\hline $\begin{array}{l}\text { Water } \\
\text { year }\end{array}$ & $\begin{array}{l}\text { Months } \\
\text { sampled }\end{array}$ & $\begin{array}{l}\text { Suspended } \\
\text { sediment load } \\
\text { (tons) }\end{array}$ & $\begin{array}{c}\text { Suspended } \\
\text { sediment yield } \\
\text { (tons/mi') }\end{array}$ & $\begin{array}{l}\text { Average daily } \\
\text { sediment yield } \\
\text { (tons/mi²/d) }\end{array}$ & $\begin{array}{c}\text { Total water } \\
\text { flow } \\
\left(\mathrm{ft}^{3} / \mathbf{s}\right)\end{array}$ & $\begin{array}{l}\text { VW sediment } \\
\text { concentration } \\
(\mathrm{mg} / \mathrm{L})\end{array}$ \\
\hline \multicolumn{7}{|c|}{ Milwaukee River near Cedarburg } \\
\hline 1975 & -- & -- & -- & -- & -- & -- \\
\hline 1976 & -- & -- & -- & -- & -- & -- \\
\hline 1977 & -- & -- & -- & -- & -- & -- \\
\hline 1982 & July-Sept. & 2,090 & 3.44 & 0.04 & 16,700 & 46 \\
\hline 1983 & Oct.-Sept. & 14,700 & 24.2 & .07 & 204,000 & 27 \\
\hline 1984 & Oct.-Sept. & 20,400 & 33.6 & .09 & 196,000 & 39 \\
\hline 2004 & June-Sept. & 7,290 & 12.0 & .10 & 98,100 & 28 \\
\hline 2005 & Oct.-Sept. & 8,340 & 13.8 & .04 & 113,635 & 27 \\
\hline \multicolumn{7}{|c|}{ Milwaukee River at Milwaukee } \\
\hline 1975 & -- & -- & -- & -- & -- & -- \\
\hline 1976 & -- & -- & -- & -- & -- & -- \\
\hline 1977 & -- & -- & -- & -- & -- & -- \\
\hline 1982 & July-Sept. & 2,850 & 4.09 & 0.04 & 20,300 & 52 \\
\hline 1983 & Oct.-Sept. & 27,600 & 39.7 & .11 & 233,000 & 44 \\
\hline 1984 & Oct.-Sept. & 44,600 & 64.1 & .18 & 227,000 & 73 \\
\hline 2004 & June-Sept. & 9,380 & 13.5 & .11 & 114,000 & 31 \\
\hline 2005 & Oct.-Sept. & 8,300 & 11.9 & .03 & 132,000 & 23 \\
\hline \multicolumn{7}{|c|}{ Menomonee River at Wauwatosa } \\
\hline 1975 & Jan.-Sept. & 15,300 & 124 & 0.46 & 34,800 & 163 \\
\hline 1976 & Oct.-Sept. & 10,400 & 84.6 & .23 & 36,400 & 106 \\
\hline 1977 & Oct.-Sept. & 6,840 & 55.6 & .15 & 15,800 & 161 \\
\hline 1982 & June-Sept. & 2,570 & 20.9 & .17 & 5,390 & 177 \\
\hline 1983 & Oct.-Sept. & 10,500 & 85.4 & .23 & 45,400 & 86 \\
\hline 1984 & Oct.-Sept. & 9,140 & 74.3 & .20 & 43,300 & 78 \\
\hline 2004 & June-Sept. & 2,300 & 18.8 & .15 & 13,300 & 64 \\
\hline 2005 & Oct.-Sept. & 3,650 & 29.7 & .08 & 26,600 & 51 \\
\hline \multicolumn{7}{|c|}{ Kinnickinnic River at S. 11th Street at Milwaukee } \\
\hline 1975 & -- & -- & -- & -- & -- & -- \\
\hline 1976 & -- & -- & -- & -- & -- & -- \\
\hline 1977 & -- & -- & -- & -- & -- & -- \\
\hline 1982 & -- & -- & -- & -- & -- & -- \\
\hline 1983 & Oct.-Sept. & 5,380 & 286 & 0.78 & 9,810 & 203 \\
\hline 1984 & Oct.-Sept. & 6,720 & 357 & .98 & 8,740 & 285 \\
\hline 2004 & June-Sept. & 2,060 & 110 & .90 & 3,370 & 227 \\
\hline 2005 & Oct.-Sept. & 2,380 & 127 & .35 & 6,320 & 140 \\
\hline
\end{tabular}


Table 17. Monthly and annual suspended-sediment loads for four Phase II sites in the Milwaukee Metropolitan Sewerage District planning area, Wis., for water years 2004 and 2005.

[WY, water year]

\begin{tabular}{|c|c|c|c|c|}
\hline \multirow[b]{2}{*}{ Month } & \multicolumn{4}{|c|}{ Suspended sediment (tons) } \\
\hline & $\begin{array}{c}\text { Milwaukee River } \\
\text { near Cedarburg }\end{array}$ & $\begin{array}{l}\text { Milwaukee River } \\
\text { at Milwaukee }\end{array}$ & $\begin{array}{l}\text { Menomonee River } \\
\text { at Wauwatosa }\end{array}$ & $\begin{array}{c}\text { Kinnickinnic River } \\
\text { at S. 11th Street } \\
\text { at Milwaukee }\end{array}$ \\
\hline \multicolumn{5}{|c|}{ Water year 2004} \\
\hline June & 6,000 & 6,960 & 862 & 370 \\
\hline July & 1,020 & 1,320 & 1,020 & 794 \\
\hline August & 214 & 850 & 419 & 887 \\
\hline September & 60 & 250 & 12 & 5 \\
\hline WY total & 7,290 & 9,380 & 2,300 & 2,060 \\
\hline \multicolumn{5}{|c|}{ Water year 2005} \\
\hline October & 50 & 528 & 50 & 14 \\
\hline November & 67 & 537 & 50 & 31 \\
\hline December & 1,470 & 985 & 72 & 58 \\
\hline January & 206 & 429 & 678 & 560 \\
\hline February & 1,720 & 1,280 & 649 & 214 \\
\hline March & 2,200 & 1,580 & 513 & 39 \\
\hline April & 793 & 1,630 & 282 & 265 \\
\hline May & 830 & 460 & 332 & 202 \\
\hline June & 149 & 295 & 198 & 73 \\
\hline July & 292 & 233 & 200 & 156 \\
\hline August & 309 & 94 & 72 & 25 \\
\hline September & 256 & 250 & 551 & 745 \\
\hline WY total & 8,340 & 8,300 & 3,650 & 2,380 \\
\hline
\end{tabular}




\section{Mercury}

Mercury $(\mathrm{Hg})$ is a natural element, but human activity has greatly increased its abundance in the environment (Mason and others, 1994). The principal source of mercury to the environment is atmospheric emissions from fossil-fuel combustion and waste incineration. However, in some settings other potential mercury sources can be important, such as mining and industrial effluents. Unlike most contaminants, natural processes in the environment actually increase mercury toxicity by converting some of the mercury to methylmercury $(\mathrm{MeHg})$, the most toxic and bioaccumulative form of mercury (Wiener and others, 2003). Methylmercury constitutes nearly all the mercury found in the top levels of aquatic food webs, yet it rarely exceeds 10 percent of the total mass of mercury in sediment or water. Gaps in our understanding of the processes and factors controlling exposure to methylmercury (for example, methylation, demethylation and biotic uptake) are key challenges facing scientists investigating the mercury problem; therefore, much attention is placed on understanding the sources, transport, and fate of methylmercury in the environment.

In order to assess current levels of mercury contamination in the MMSD planning area, samples of water, bed sediment, and fish tissue were analyzed for mercury concentrations. This section of the report discusses concentrations in water samples, which were collected at stream and harbor sites in 2004 and 2005 during summer (July and August) low- and high-flow events, (resulting in a total of 4 mercury samples collected at each of the 21 sites over the study period). Concentrations in bed sediment and fish tissues are discussed in later sections of this report.

\section{Total Mercury}

The overall median concentrations of dissolved and particulate total mercury in stream samples were 1.06 and $1.42 \mathrm{ng} / \mathrm{L}$, respectively. These concentrations are similar to those observed in stream water from other urban areas across the nation (Krabbenhoft and others, 1999). Median dissolved total mercury concentrations indicated a positive

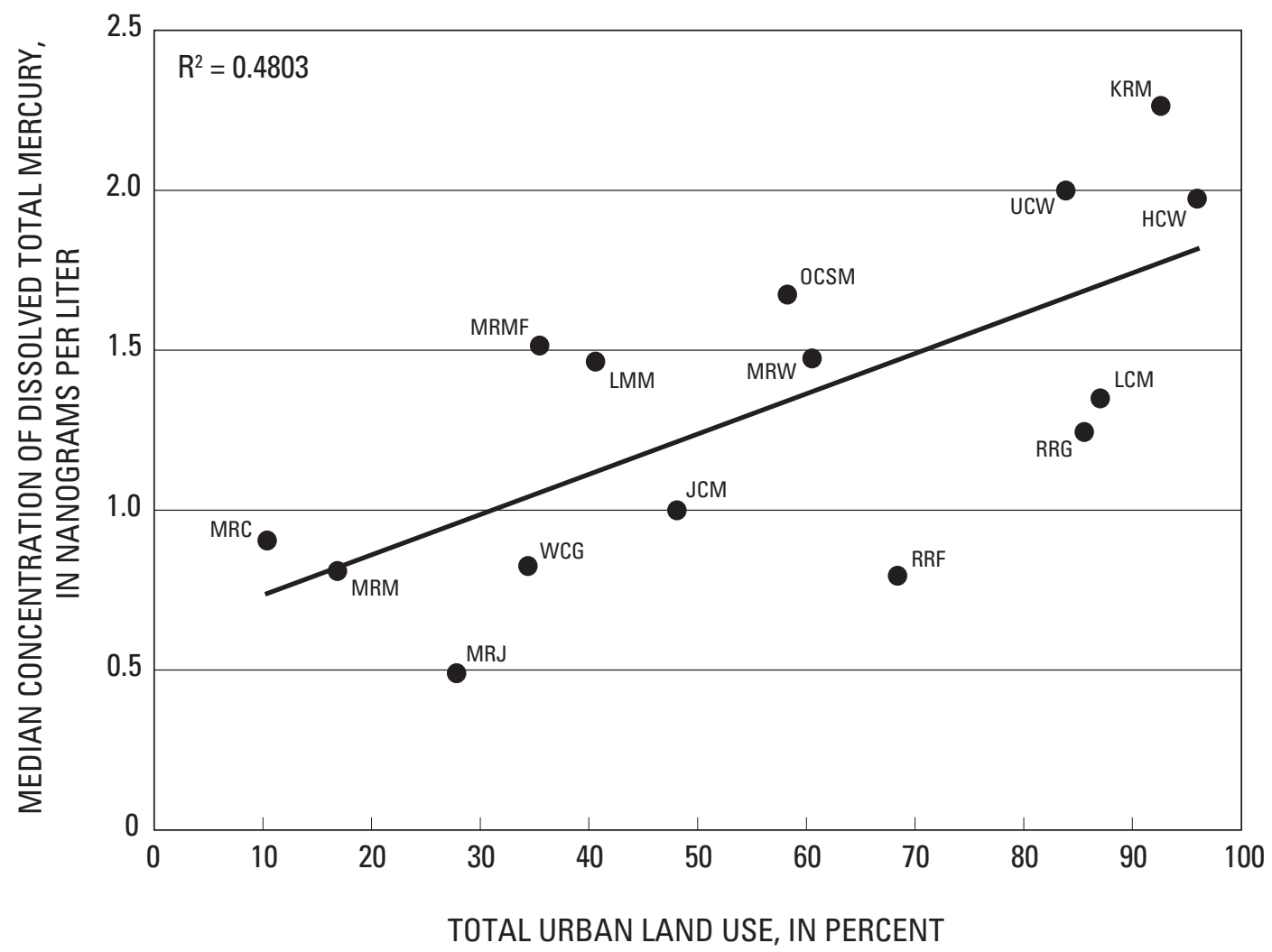

Figure 24. Median dissolved total mercury concentrations plotted against percent urban land use in site drainage basins for 15 stream sites in the Milwaukee Metropolitan Sewerage District planning area, Wis. Site abbreviations listed in table 1. 
relation with increasing urban land use (fig. 24). Highest median dissolved total mercury concentrations were found in samples from the Kinnickinnic River $(2.26 \mathrm{ng} / \mathrm{L})$, Underwood Creek (2.00 ng/L), and Honey Creek (1.98 $\mathrm{ng} / \mathrm{L}$ ) sites (fig. 25). The lowest median dissolved total mercury concentration was at Milwaukee River at Mouth $(0.49 \mathrm{ng} / \mathrm{L})$. Medians at the remaining sites ranged from 0.80 to $1.68 \mathrm{ng} / \mathrm{L}$. Highest median particulate total mercury concentrations were found in samples from Menomonee River at Wauwatosa (4.34 ng/L), Oak Creek ( $3.25 \mathrm{ng} / \mathrm{L})$, and Little Menomonee River (2.84 ng/L). Medians at the remaining sites ranged from 0.68 to 2.16 $\mathrm{ng} / \mathrm{L}$. Median particulate total mercury concentrations indicated no consistent response in relation to land use.
The overall medians of dissolved and particulate total mercury concentrations in harbor samples $(0.42$, $0.18 \mathrm{ng} / \mathrm{L}$, respectively) were notably lower than those in stream samples. Highest dissolved and particulate median concentrations in the harbor sites were found at the Middle Mid-Harbor Milwaukee Outer Harbor site $(\mathrm{OH}-03)(0.60$ and $1.05 \mathrm{ng} / \mathrm{L}$, respectively)(fig. 25). Median dissolved total mercury concentrations at the remaining harbor sites ranged from 0.14 to $0.51 \mathrm{ng} / \mathrm{L}$. Median particulate total mercury concentrations at the remaining harbor sites ranged from 0.08 to $0.31 \mathrm{ng} / \mathrm{L}$.

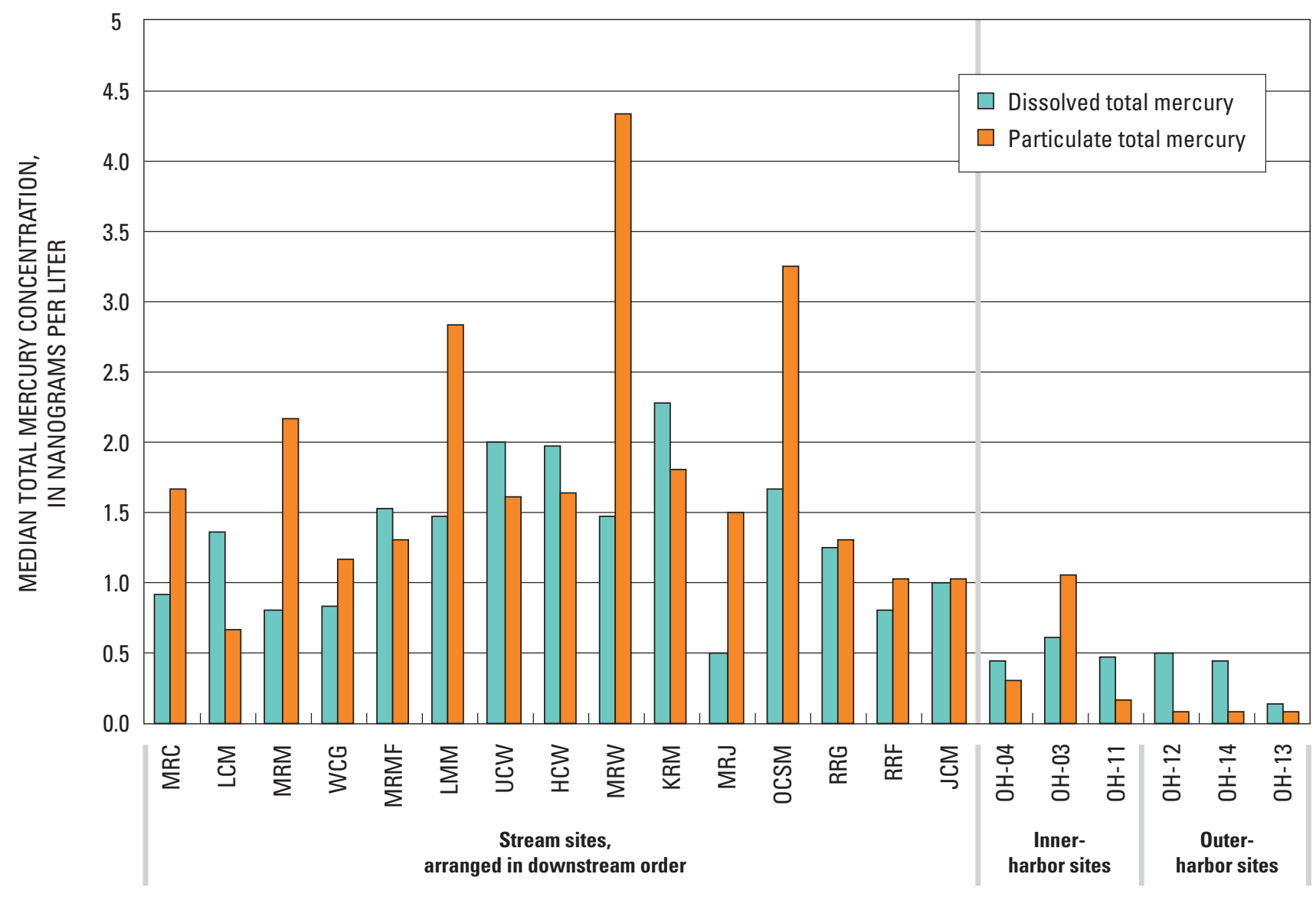

Figure 25. Median concentrations of total mercury, by site, in the Milwaukee Metropolitan Sewerage District planning area, Wis. Site abbreviations listed in table 1. 


\section{Methylmercury}

Median dissolved and particulate methylmercury concentrations for all stream samples were 0.08 , and 0.04 $\mathrm{ng} / \mathrm{L}$, respectively. These concentrations were much higher (156 percent difference) than methylmercury concentrations in streamwater from urban areas across the Nation (Krabbenhoft and others, 1999). Highest median dissolved methylmercury concentrations were observed in samples from the Menomonee River at Menomonee Falls (0.17 $\mathrm{ng} / \mathrm{L})$ and Milwaukee River near Cedarburg (0.12 ng/L) sites (fig. 26). Median concentrations at the remaining sites ranged from less than 0.04 to $0.10 \mathrm{ng} / \mathrm{L}$. Highest median particulate methylmercury concentrations were observed in samples from Menomonee River at Wauwatosa (0.12 $\mathrm{ng} / \mathrm{L})$. Median concentrations at the remaining sites ranged from 0.02 to $0.09 \mathrm{ng} / \mathrm{L}$. Median dissolved and particulate methylmercury concentrations indicated no consistent response in relation to land use.
Overall, methylmercury concentrations at harbor sites were much lower than those at stream sites. Dissolved methylmercury concentrations in all but one harbor sample were below the reporting level of $0.04 \mathrm{ng} / \mathrm{L}$ (fig. 26). Similarly, particulate methylmercury concentrations for most harbor samples were at or below the reporting level of $0.01 \mathrm{ng} / \mathrm{L}$. The highest median particulate methylmercury concentrations were found at the Middle Mid-Harbor Milwaukee Outer Harbor site (OH-03)(0.02 ng/L) and the North Mid-Harbor Milwaukee Outer Harbor site $(\mathrm{OH}-$ 04)(0.02 ng/L).

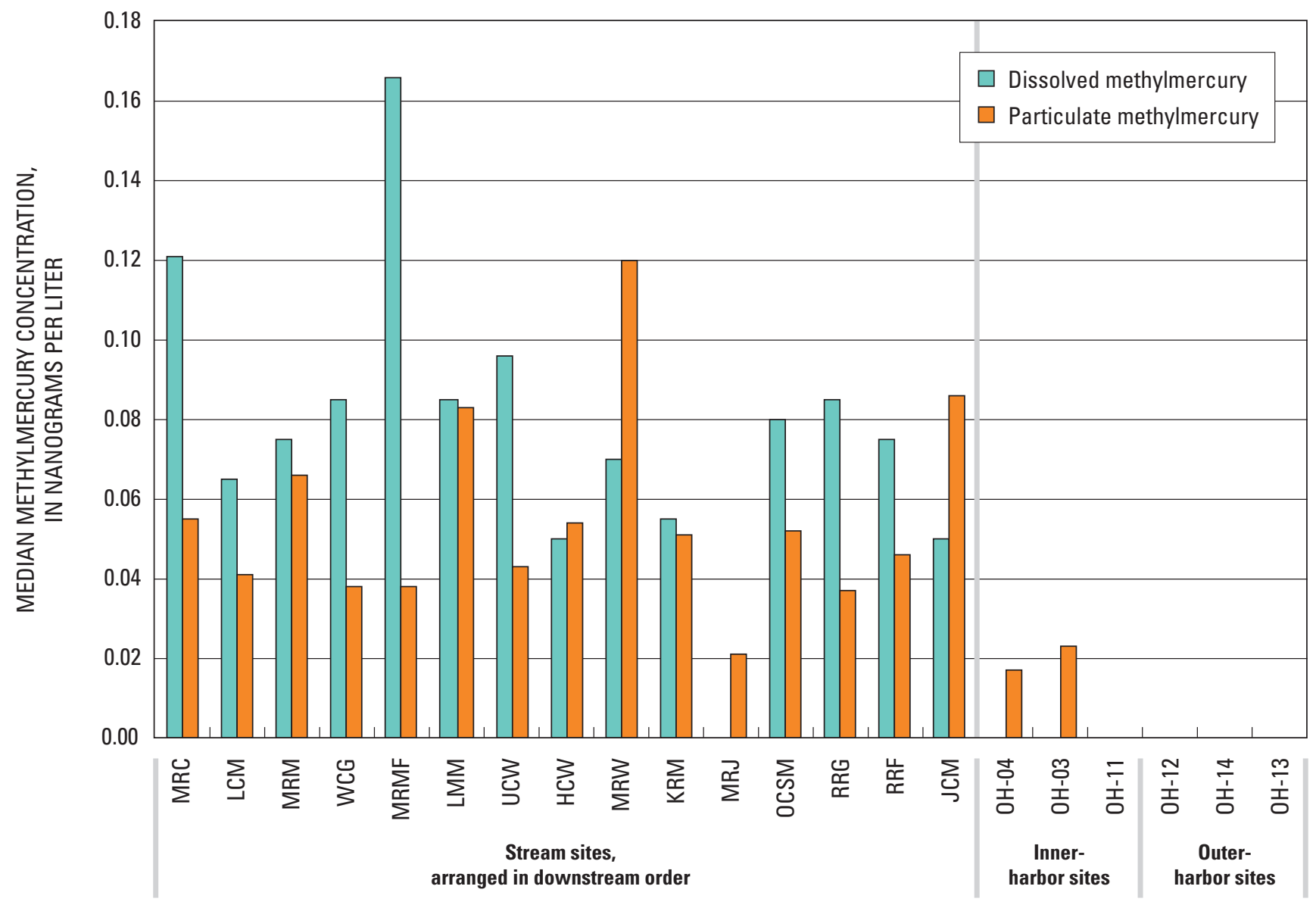

Figure 26. Median concentrations of methylmercury, by site, in the Milwaukee Metropolitan Sewerage District planning area, Wis. Site abbreviations listed in table 1. 


\section{Indicator Organisms}

Indicator organisms are microorganisms whose presence in water indicates probable presence of pathogens (disease-causing organisms). Ideally, such microorganisms are nonpathogenic, occur consistently in pathogen-contaminated water, do not multiply in waters, are reliably detectable even at low concentrations, and are present in greater numbers than and have similar survival times to pathogens. The waterborne pathogens of interest during Phase II were bacterial, viral, and protozoal. Testing was limited to bacterial and viral indicators because, to date, no adequate indicator protozoa have been defined (Mara and Horan, 2003).

The indicators used during Phase II-fecal coliforms, Escherichia coli (E. coli), and coliphage-were chosen because of their efficacy at predicting pathogen presence and their widespread use in water-quality monitoring in the United States. Traditionally, the fecal coliform group has been used as an indicator of bacterial pathogen presence and general wastewater contamination (U.S. Environmental Protection Agency, 1976). In 1986, the USEPA updated its guidance to recommend that a particular fecal coliform member, E. coli, be monitored instead because of its stronger relation to the occurrence of swimming-associated gastrointestinal illness (Dufour, 1984). Coliphage are a class of viruses that infect $E$. coli. They have higher resistance to environmental stresses and disinfection than bacteria do and are therefore thought to mirror the survival rates of enteric viruses more closely than their bacterial counterparts (Mara and Horan, 2003).

The many detections in indicator data sets from the MMSD planning area generally allowed for the use of typical statistical descriptors in this report. Wherever possible, concentrations are given as medians. Where data were insufficient to do this and results were widely dispersed, results are compared in terms of ranges and maximum concentrations.

\section{Fecal Coliforms}

In 1976, the USEPA established a water-quality criterion stating that the acceptable limit for fecal coliform concentration in bathing waters was $200 \mathrm{col} / 100 \mathrm{~mL}$ (U.S. Environmental Protection Agency, 1976). Historical data are available for fecal coliforms and were summarized in the Phase I report (Schneider and others, 2004).
Fecal coliform concentrations in stream samples ranged from less than 10 to $58,000 \mathrm{col} / 100 \mathrm{~mL}$, with a median concentration of $350 \mathrm{col} / 100 \mathrm{~mL}$. Median concentrations at the majority of stream sites (73 percent) were above the USEPA criterion of $200 \mathrm{col} / 100 \mathrm{~mL}$. Median fecal coliform concentrations indicate a positive relation with increasing urban land use (fig. 27). The Honey Creek site had the highest median concentration $(1,900 \mathrm{col} / 100$ $\mathrm{mL}$ )(fig. 28), and the Milwaukee River at Mouth site had the lowest $(55 \mathrm{col} / 100 \mathrm{~mL})$. Median concentrations at remaining sites ranged from 130 to $695 \mathrm{col} / 100 \mathrm{~mL}$.

Although higher maximum concentrations were found in stream samples collected during low-flow events $(58,000 \mathrm{col} / 100 \mathrm{~mL})$ than in those from high-flow events $(6,600 \mathrm{col} / 100 \mathrm{~mL})$, median concentrations indicated no consistent response in relation to flow (fig. 29A). No patterns were evident in relation to seasonality (fig. 29B); however, when flows were combined with seasonality, a consistent response was apparent (fig. 29C). Summer low-flow samples had the highest median concentration of fecal coliform, and summer high-flow events had the lowest; the opposite was true for winter samples.

Data were available for Phase I and Phase II fecal coliform concentration comparisons at ten sites (appendix 5). At most sites ( 7 of 10), median fecal coliform concentrations decreased from Phase I to Phase II, where percent differences ranged from -97 percent at Underwood Creek to -29 percent at Menomonee River at Menomonee Falls. However, there was one site with a notable increase: Jewel Creek, which had no concentrations above the reporting level $(10 \mathrm{col} / 100 \mathrm{~mL})$ in the two samples summarized for Phase I and a median concentration of $165 \mathrm{col} / 100$ $\mathrm{mL}$ in samples collected for Phase II. The remaining two sites, Root River near Franklin and Root River at Grange Avenue, indicated no notable differences.

The overall median fecal coliform concentration at harbor sites (less than $10 \mathrm{col} / 100 \mathrm{~mL}$ ) was lower than that for stream sites $(350 \mathrm{col} / 100 \mathrm{~mL})$, and may be attributed to organism die-off due to environmental stress or dilution when mixing with water from Lake Michigan. Median concentrations in samples from the inner-harbor sites ranged from less than 10 to $20 \mathrm{col} / 100 \mathrm{~mL}$ (fig 28). No fecal coliform were detected in samples collected from any of the three sites in the outer harbor. Harbor samples indicated no seasonal response (fig. 29D). 


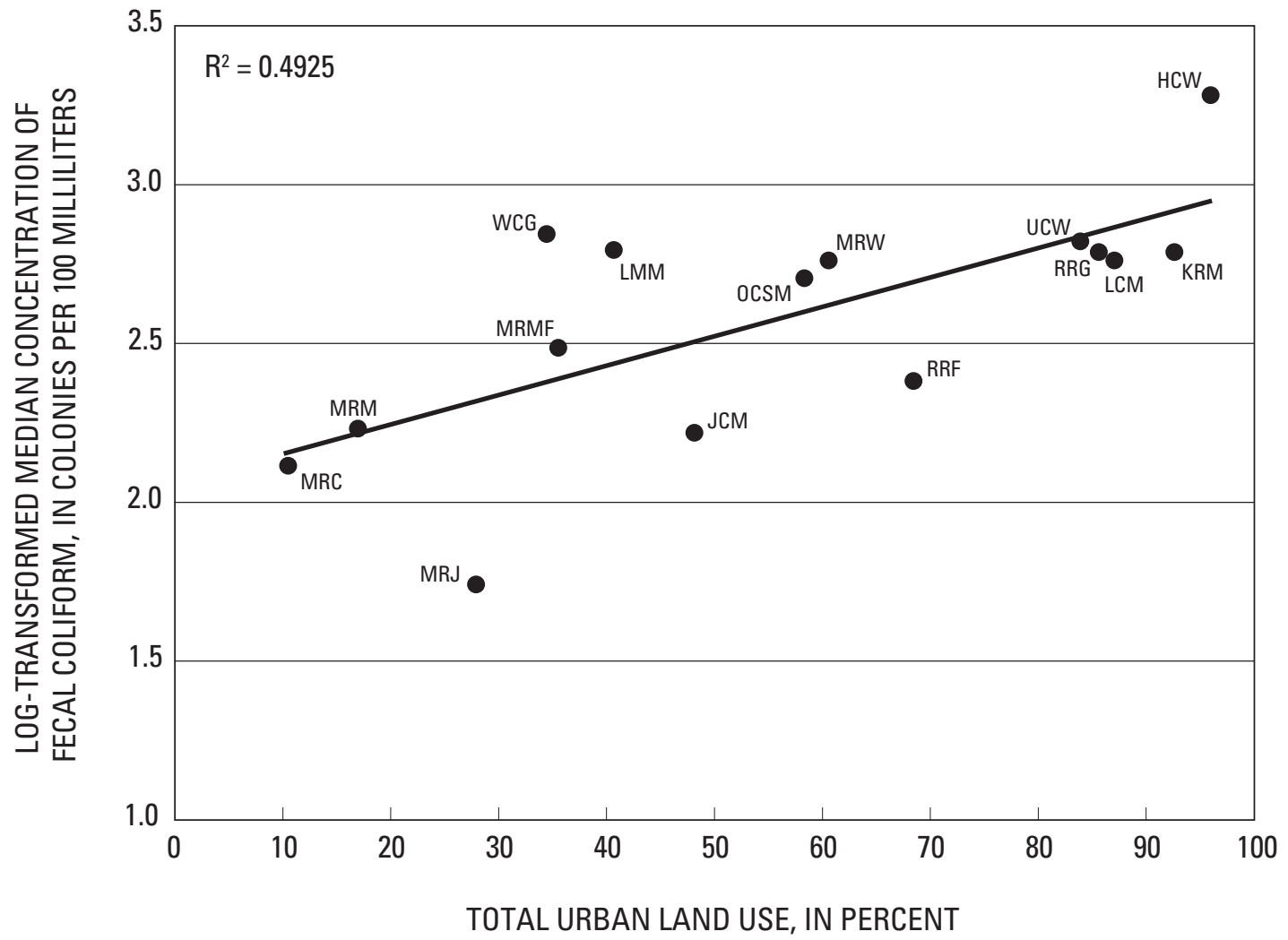

Figure 27. Median concentrations of fecal coliform (log transformed) plotted against percent urban land use in site drainage basins for 15 stream sites in the Milwaukee Metropolitan Sewerage District planning area, Wis. Site abbreviations listed in table 1. 


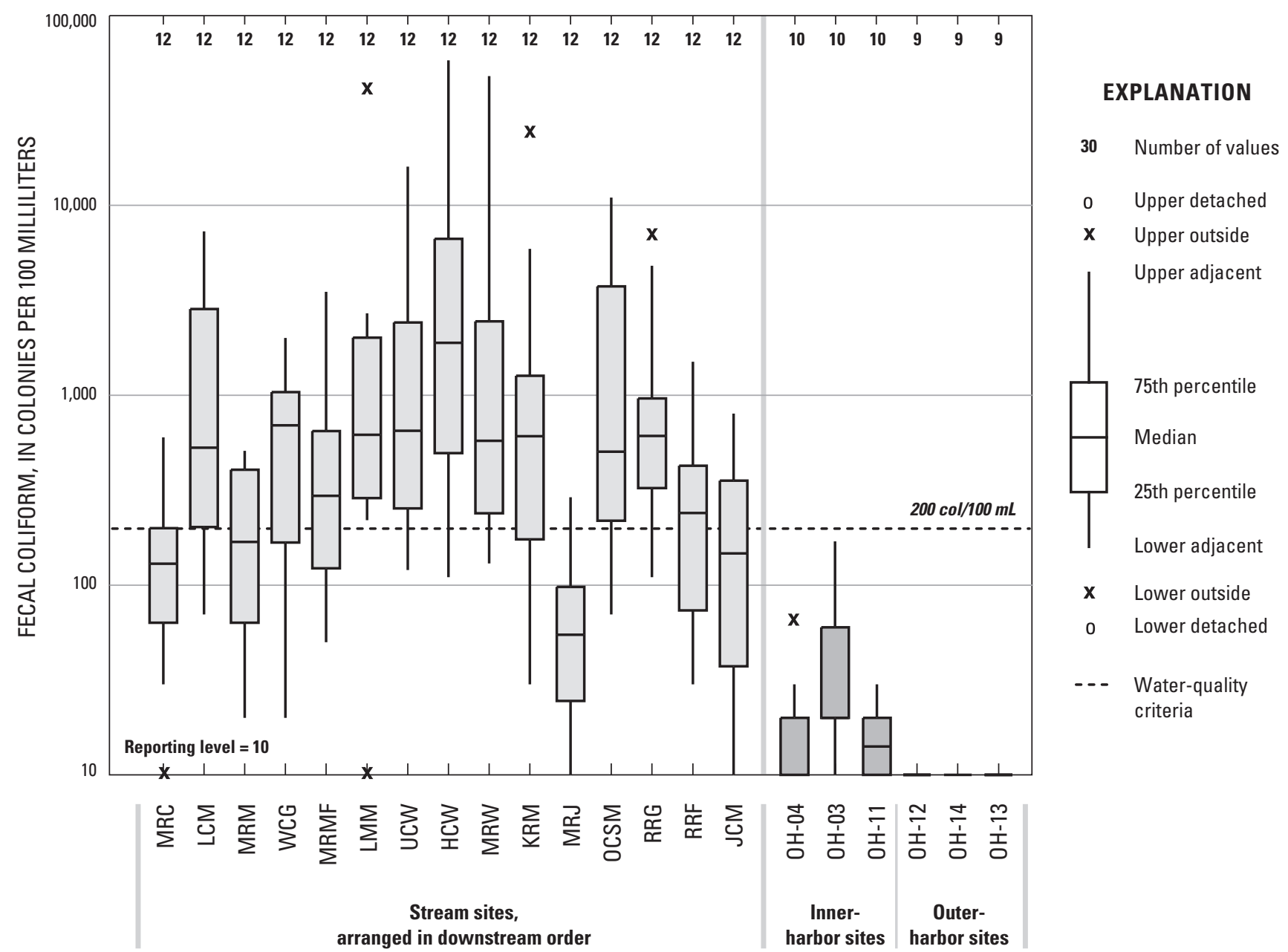

Figure 28. Distribution of fecal coliform concentrations, by site, in the Milwaukee Metropolitan Sewerage District planning area, Wis. Water-quality criterion line represents the U.S. Environmental Protection Agency acceptable limit for fecal coliform concentrations in recreational waters $(200 \mathrm{col} / 100 \mathrm{~mL}$ ) (U.S. Environmental Protection Agency, 1976). Site abbreviations listed in table 1. 

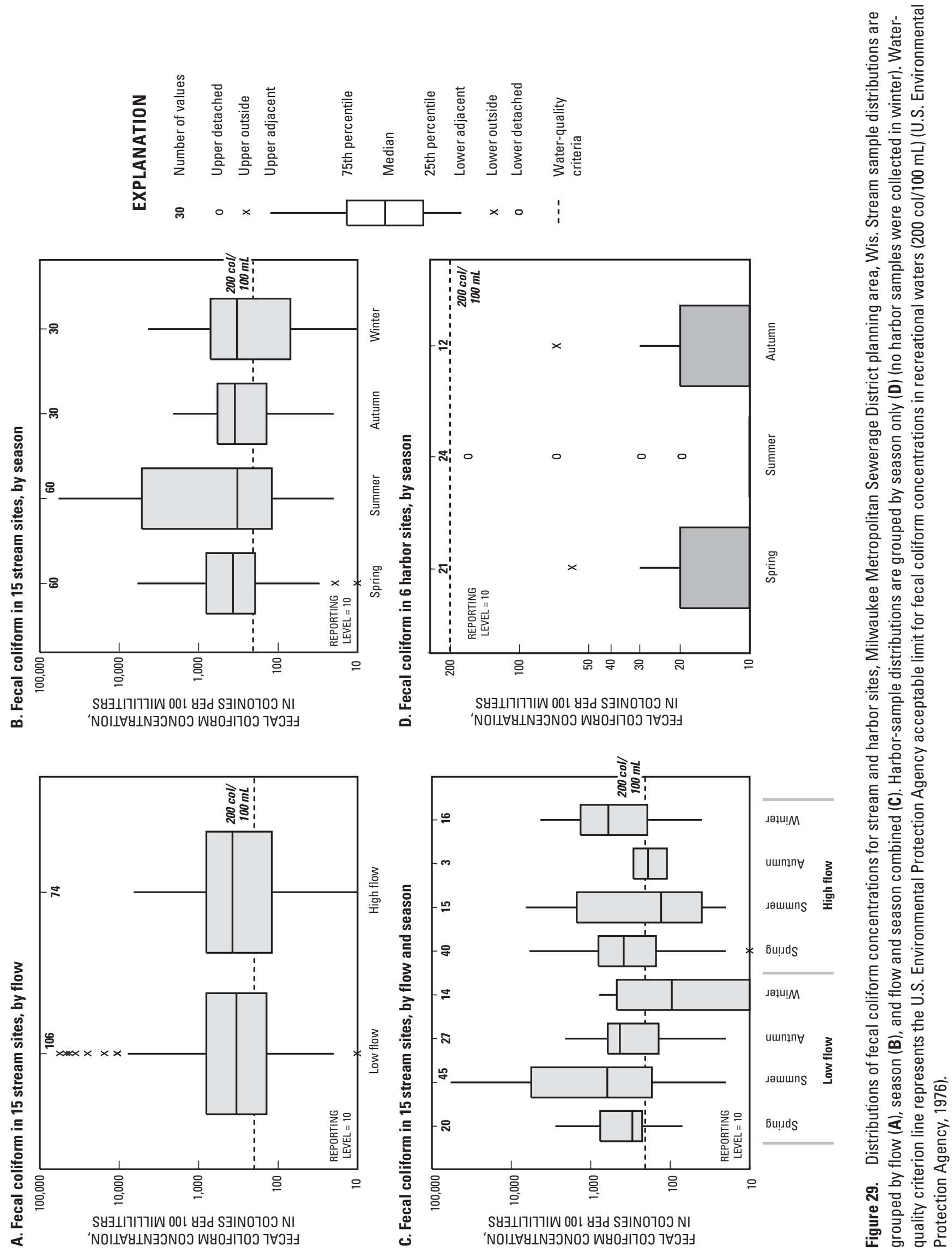

. 


\section{Escherichia coli}

In its 1986 guidance on $E$. coli as an indicator of contamination in freshwater systems, USEPA established a criterion for designated beach areas wherein the single sample maximum density allowed is 235 colonies of E. coli per 100mL (U.S. Environmental Protection Agency, 1986). Historical data are available for E. coli and were summarized in the Phase I report (Schneider and others, 2004).

E. coli concentrations in stream samples ranged from less than 1 to 34,000 MPN/100 mL, with a median of $420 \mathrm{MPN} / 100 \mathrm{~mL}$. Median concentrations at the majority of stream sites (67 percent) were above the USEPA criterion of $235 \mathrm{col} / 100 \mathrm{~mL}^{4}$. Median E. coli concentrations indicated a positive relation with increasing urban land use (fig. 30). The Honey Creek site had the highest median (2,000 MPN/100 mL)(fig. 31), and Milwaukee River near Cedarburg and Milwaukee River at Mouth had

\footnotetext{
${ }^{4}$ In this report units of col/100 $\mathrm{mL}$ were considered equivalent to units of MPN/100 mL (Wisconsin Department of Natural Resources, [n.d.]).
}

the lowest (44 and 57 MPN/100 mL, respectively). Median concentrations at remaining sites ranged from 180 to 990 MPN/100 mL.

Median concentrations indicated no consistent response in relation to flow (fig. 32A), but a consistent response was evident in relation to seasonality (fig. 32B). Median concentrations were generally higher in summer and winter than during other times of the year. A consistent response was also observed when flows were combined with seasonality (fig. 32C). Summer low-flow samples had the highest median concentration of E. coli, and summer high-flow samples had the lowest; the opposite was true for winter samples.

Data were available for Phase I and Phase II E. coli concentration comparisons at five sites (appendix 5). The Kinnickinnic River was the only site with an increase from Phase I to Phase II (28 percent difference). Two sites indicated a notable decrease: Lincoln Creek (-35 percent difference) and Menomonee River at Wauwatosa (-21 percent difference). The two remaining sites, Honey Creek and Menomonee River at Menomonee Falls, indicated no notable differences.

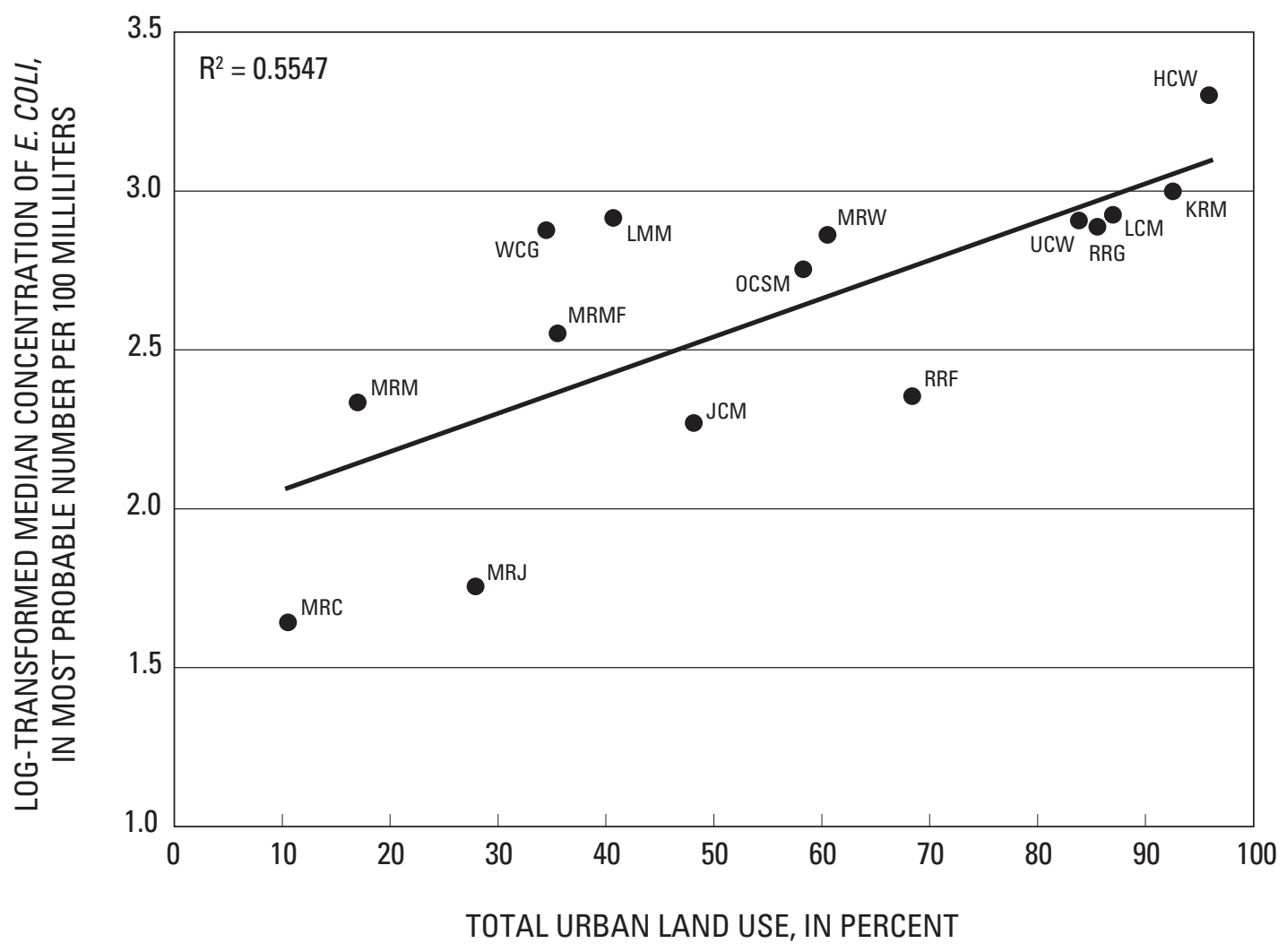

Figure 30. Median concentrations of E. coli (log transformed) plotted against percent urban land use in site drainage basins for 15 stream sites in the Milwaukee Metropolitan Sewerage District planning area, Wis. Site abbreviations listed in table 1. 
The overall median E. coli concentration at harbor sites (2 MPN/100 mL) was lower than that for stream sites (420 MPN/100 mL) and may be attributed to organism die-off or dilution when mixing with water from Lake Michigan. Median concentrations in samples from the inner-harbor sites ranged from 3 to $19 \mathrm{MPN} / 100 \mathrm{~mL}$ (fig. 31), whereas medians in samples from the outer-harbor sites were lower than those from the inner harbor, ranging from less than 1 to $1 \mathrm{MPN} / 100 \mathrm{~mL}$. Harbor samples did not indicate a consistent seasonal response (fig. 32D).

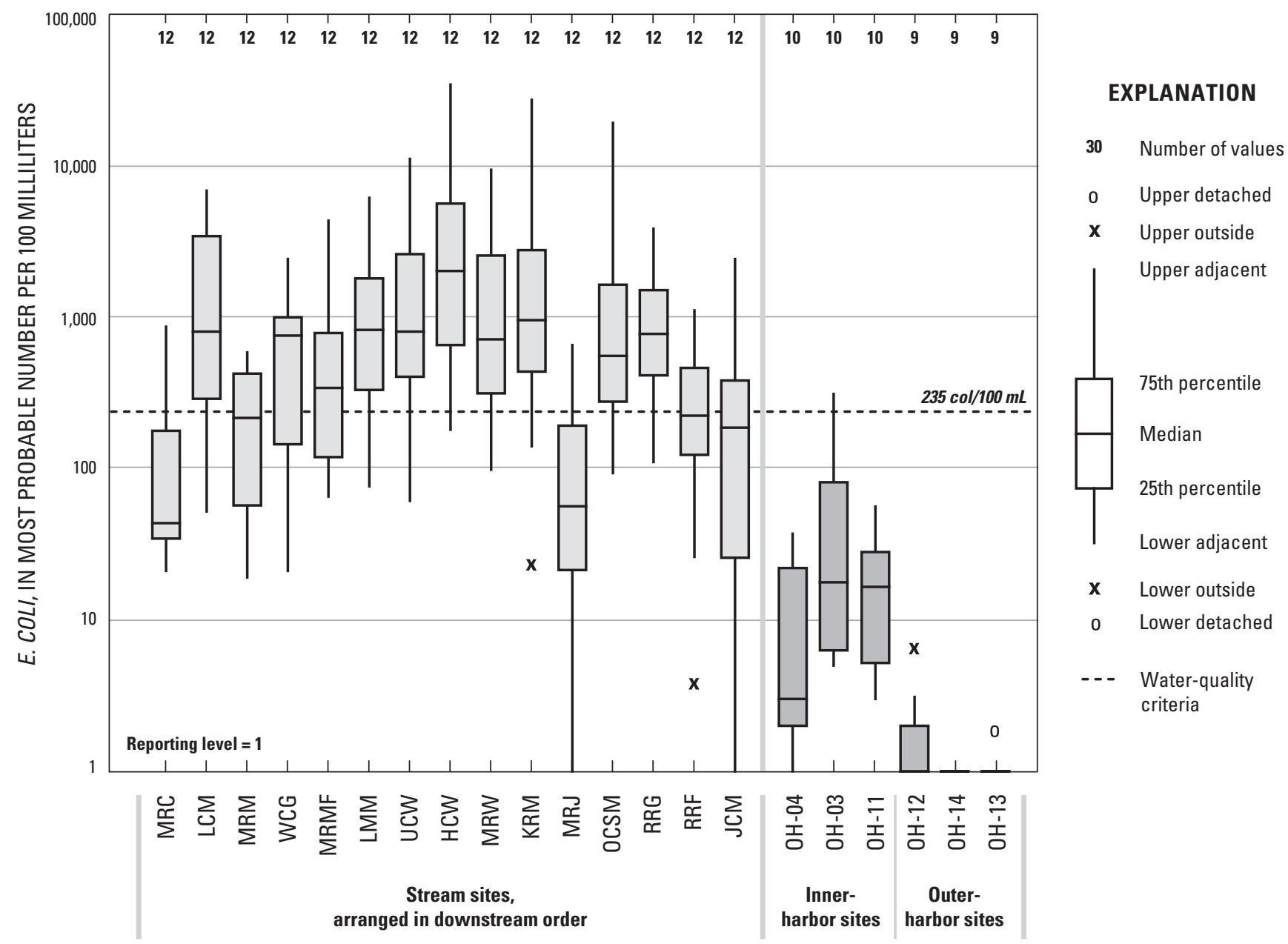

Figure 31. Distribution of E. coli concentrations, by site, in the Milwaukee Metropolitan Sewerage District planning area, Wis. Water-quality criterion line represents the U.S. Environmental Protection Agency single sample maximum density of $E$. coli allowed in designated beach areas (235 col/100 mL) (U.S. Environmental Protection Agency, 1986). Units of col/100 mL were considered equivalent to units of MPN/100 mL (Wisconsin Department of Natural Resources, 2006a). Site abbreviations listed in table 1. 


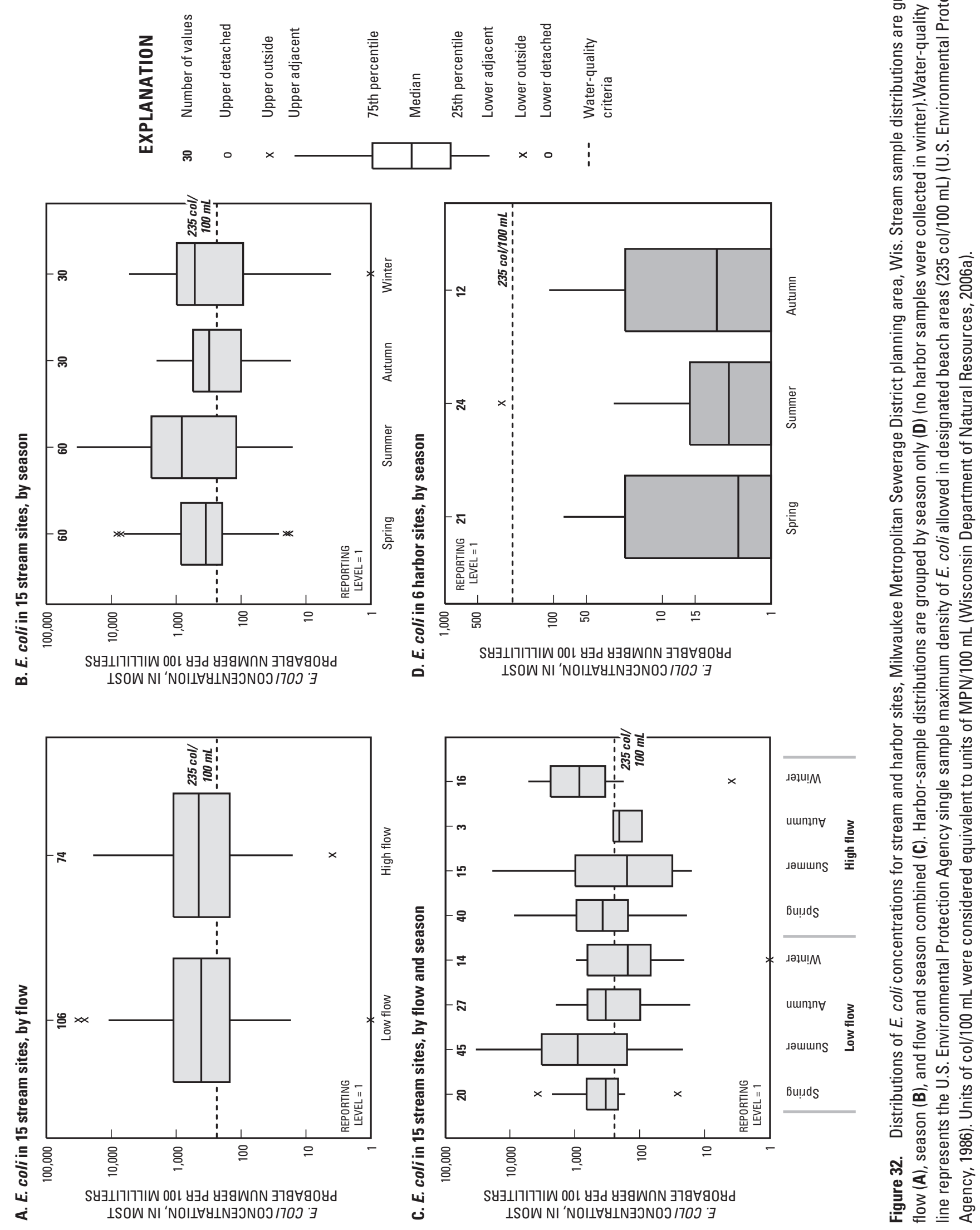




\section{Coliphage}

The group of coliphages tested for during Phase II of the MMSD Corridor Study were male-specific and therefore characterized by their infection of $E$. coli bacteria containing F-pili. Despite their high correlation with enteric virus concentrations in contaminated rivers and lakes, and their comparable resistance to environmental factors and disinfecting agents, coliphage fall short of being an ideal indicator of enteric virus presence, and a need for additional field studies of ecology and survival time still exists (Mara and Horan, 2003). Coliphage data are not present in the Phase I database and were not analyzed in conjunction with the Phase I report.

Coliphage concentrations in stream samples ranged from less than 1 to 4,400 plaques $/ 100 \mathrm{~mL}$, with an overall median of 4 plaques $/ 100 \mathrm{~mL}$. Median coliphage concentrations indicate a positive relation with increasing urban land use (fig. 33). The Menomonee River at Wauwatosa site had the highest median concentration (31 plaques/ $100 \mathrm{~mL}$ )(fig. 34), and the Willow Creek, Milwaukee River at Mouth, and Jewel Creek sites had the lowest (less than 1 plaque $/ 100 \mathrm{~mL}$ ). Median concentrations at remaining sites ranged from 1 to 22 plaques $/ 100 \mathrm{~mL}$.
Median concentrations for stream samples indicated no consistent response to flow (fig. 35A), however the maximum concentration during low-flow events was much higher $(4,400$ plaques $/ 100 \mathrm{~mL})$ than that for high-flow events ( 990 plaques $/ 100 \mathrm{~mL}$ ). Median concentrations in stream samples indicated a weak seasonal response (fig. 35B); the highest median was for summer samples (10 plaques $/ 100 \mathrm{~mL}$ ), whereas medians for the rest of the year ranged from 3 to 4 plaques $/ 100 \mathrm{~mL}$. A consistent response became more apparent when flows were combined with seasonality (fig. 35C). The summer low-flow events had the highest median concentration (12 plaques/100 mL) of any season, and summer high-flow events had the lowest (1 plaque $/ 100 \mathrm{~mL}$ ). This pattern of higher median concentrations in the low-flow-event samples (6 plaques $/ 100 \mathrm{~mL}$ ) and lower median concentrations in the high-flow-event samples ( 2 plaques $/ 100 \mathrm{~mL}$ ) held for samples collected in the spring, though the difference between medians was less dramatic. Winter concentrations indicated the opposite pattern: the lowest median concentrations occurred during low-flow events ( 2 plaques $/ 100 \mathrm{~mL}$ ) and the highest median concentrations occurred during high-flow events (6 plaques $/ 100 \mathrm{~mL}$ ).

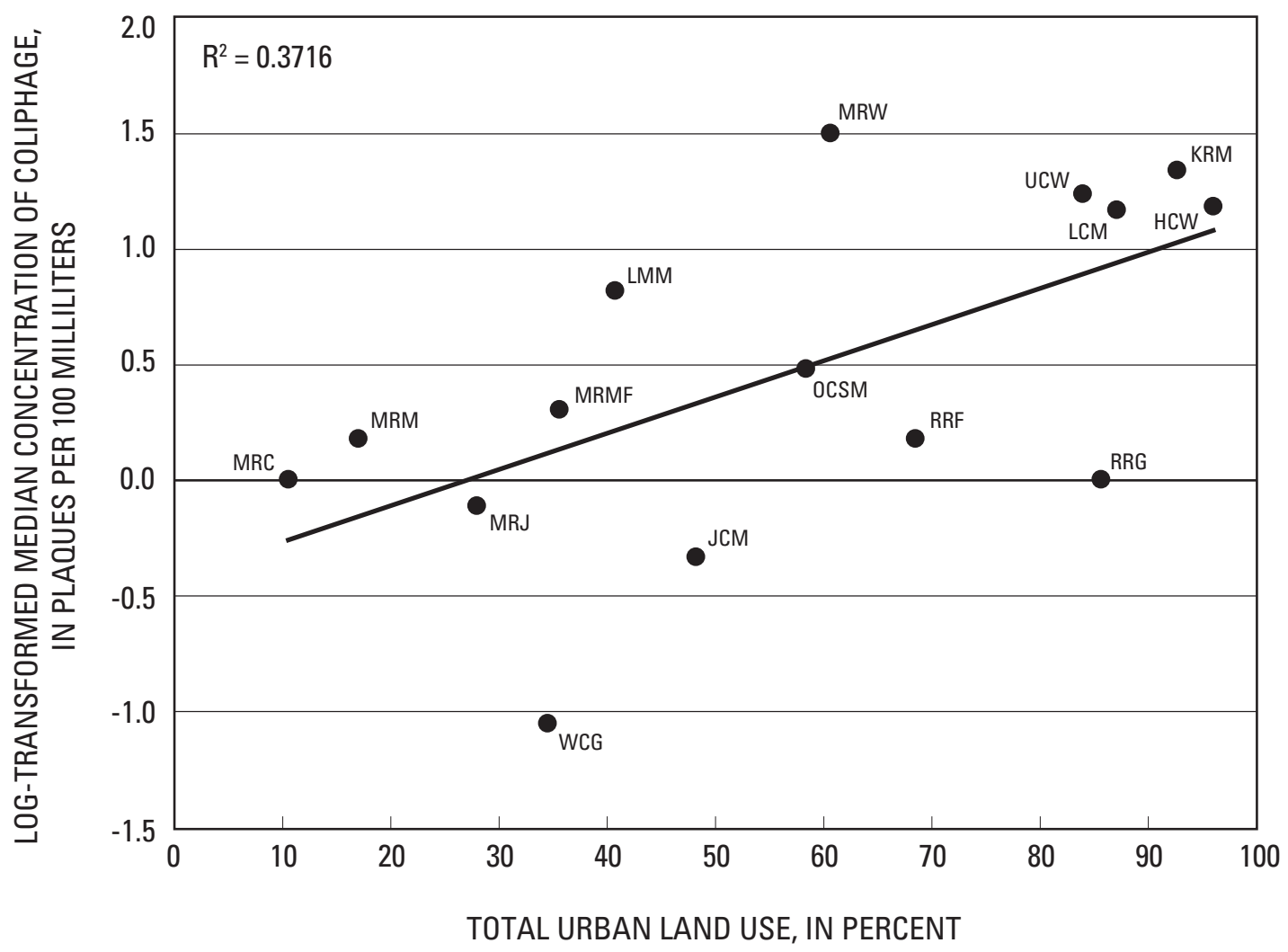

Figure 33. Median concentrations of coliphage (log transformed) plotted against percent urban land use in site drainage basins for 15 stream sites in the Milwaukee Metropolitan Sewerage District planning area, Wis. Site abbreviations listed in table 1. 


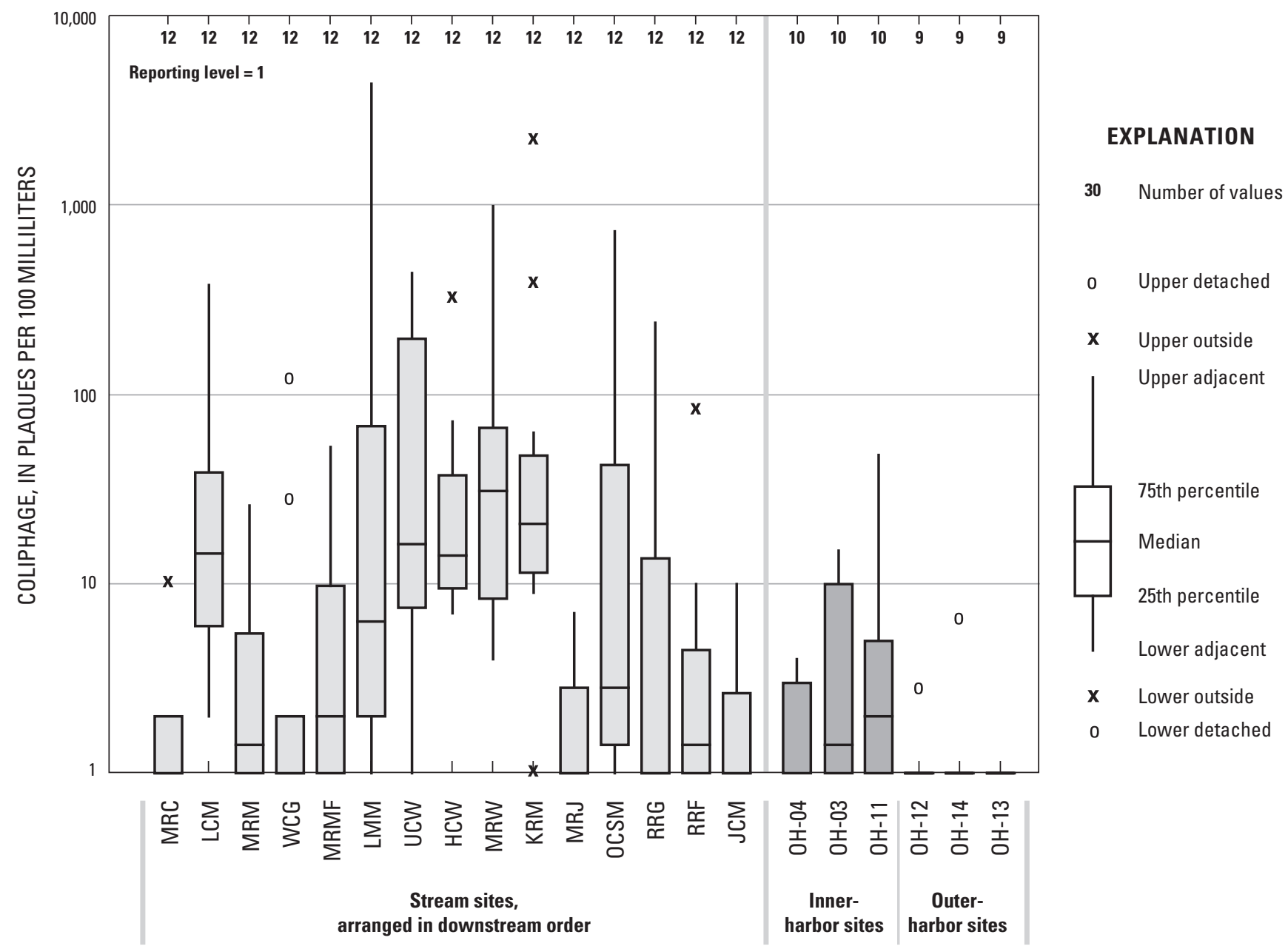

Figure 34. Distribution of coliphage concentrations, by site, in the Milwaukee Metropolitan Sewerage District planning area, Wis. Site abbreviations listed in table 1. 


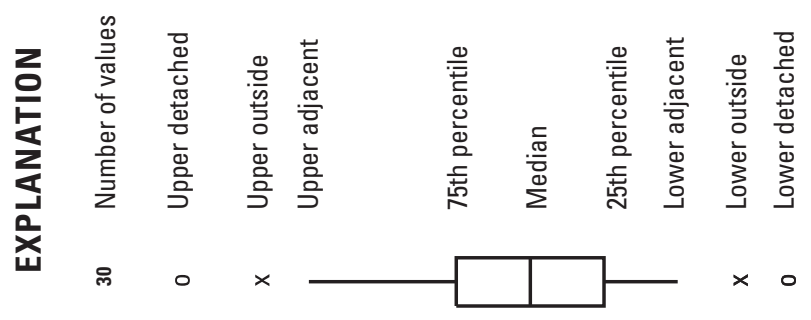

$\stackrel{\square}{\frac{0}{\sigma}}$
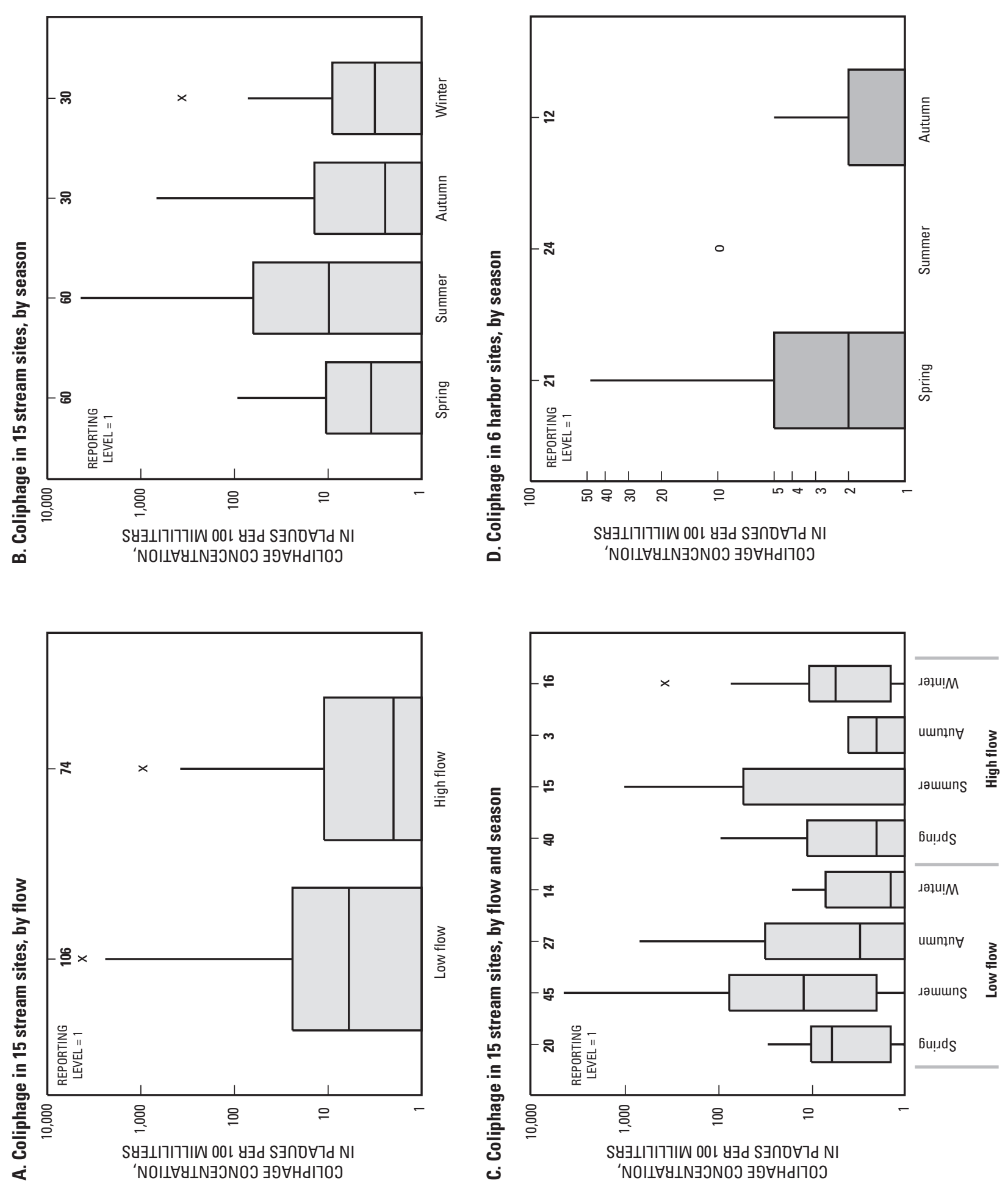

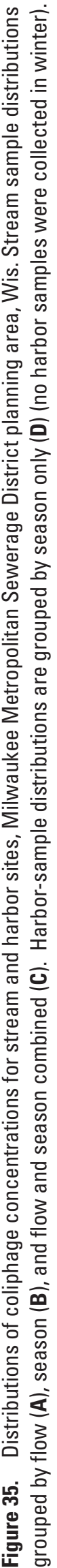


The overall median coliphage concentration at harbor sites (less than 1 plaque/100 $\mathrm{mL}$ ) was slightly lower than that for stream sites (4 plaques/100 $\mathrm{mL}$ ), and may be attributed to dilution from mixing with water from Lake Michigan. Median concentrations in samples from the inner-harbor sites ranged from less than 1 to 2 plaques/100 $\mathrm{mL}$ (fig. 34). Median concentrations in the outer-harbor samples were less than the inner-harbor samples, at less than 1 plaque $/ 100 \mathrm{~mL}$ at each of the three sites. Harbor samples collected in spring had the highest median concentration (2 plaques/100 $\mathrm{mL}$, compared to less than 1 plaque $/ 100 \mathrm{~mL}$ summer and autumn) and the highest detection frequency (DF)(67 percent) among all other seasons sampled (average DF of 27 percent)(fig. 35D).

In addition to its use as an indicator of enteric virus levels, coliphage can be used for tracking sources of fecal contamination. For Phase II of the MMSD Corridor Study, small subsets of detected coliphage were subsequently serotyped in an effort to categorize potential contamination sources. More specifically, five plaques isolated from each coliphage sample were classified as either deoxyribonucleic acid (DNA) or ribonucleic acid (RNA) phages, depending on the chemical composition of their genetic material. Any RNA coliphages detected were then serotyped into one of four general serogroups: group I, group II, group III, or group IV.

Individual serogroups originate from a limited number of sources: group I is found in human and animal feces, groups II and III are found predominantly in human feces, and group IV is found predominantly in nonhuman animal feces (Simpson and others, 2002). Therefore, the serotyping of any RNA coliphages present allowed for a broad source-tracking signal. For the purposes of this report, groups I and IV were not considered for analysis, and groups II and III were considered together as a probable indicator of human fecal contamination.
Because the method was to select only five of the coliphage plaques for further analysis, and only a fraction of these were serotyped into RNA coliform serogroups, data on various serogroup presences in samples were scarce by design. In fact, only 49 percent of all the samples collected contained a coliphage classified into any of the four serogroups. Therefore, in contrast to the general indicator data discussed previously in the report, serogroup detections were much less frequent. Whereas general indicator data contained ample detections for the description of constituent levels by standard statistical methods (for example, medians), detections of various serogroups are too scarce to be analyzed in this manner. These data are reported instead as the frequency with which detections of the combined groups were found in samples.

Groups II and III

When groups II and III were combined, the overall DF at stream sites was 14 percent. Detections for coliphage in these groups were found at 11 of the 15 sites (fig. 36). At four sites, DF was greater than or equal to 25 percent: Honey Creek (33 percent), Menomonee River at Wauwatosa (33 percent), Lincoln Creek (25 percent), and Underwood Creek (25 percent). Sites with no detections were the Milwaukee River at Milwaukee, Little Menomonee River, Root River at Grange Avenue, and Jewel Creek. DFs at remaining sites ranged from 8 to 17 percent. DFs indicated no relation to land use.

Consistent responses in DFs were observed in relation to flow and season. Flow-related DFs for stream samples were higher during low-flow events (16 percent) than during high-flow events (12 percent)(fig. 37A). For stream samples, the highest seasonal DF was in the autumn (23 percent), and the lowest was in the spring ( 8 percent) (fig. 37B). DFs for the rest of the year ranged from 13 to 17 percent. When flows were combined with seasonality, DFs were higher during low-flow events than during high-flow events for corresponding seasons, with the exception of the autumn high-flow-event category (DF of 67 percent) (fig. 37C).

The overall DF at harbor sites (16 percent) was similar to that of stream sites (14 percent). All harbor sites had detections in at least one sample (fig. 36). DFs at all inner-harbor sites were 20 percent. DFs at all outer-harbor sites were 11 percent. The highest seasonal DF at harbor sites was in the autumn (33 percent), and the lowest was in the summer (4 percent) (fig. 37D). The DF in spring was 19 percent. No harbor samples were collected in winter. 


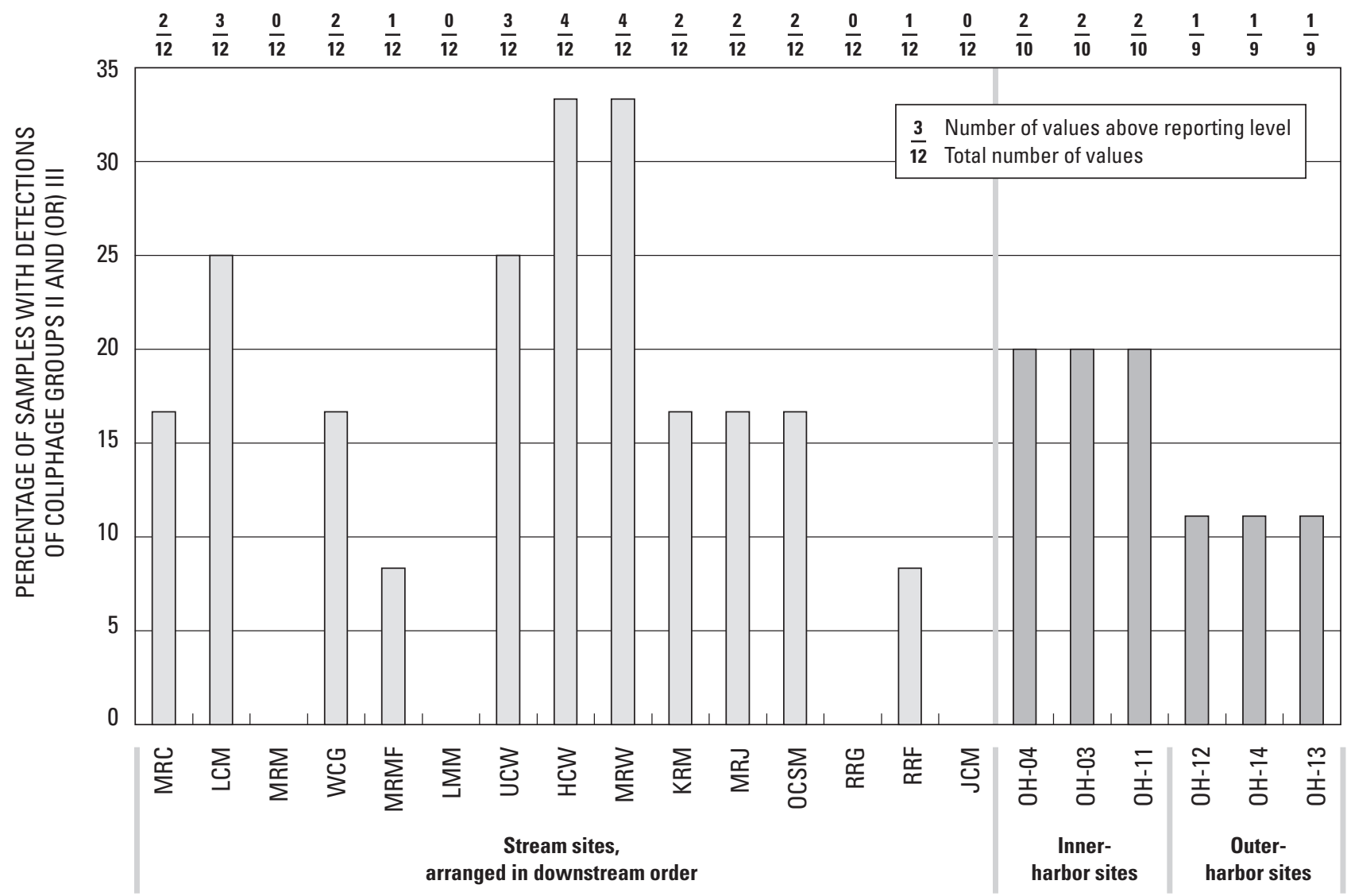

Figure 36. Detection frequency of coliphage groups II and (or) III in samples, by site, in the Milwaukee Metropolitan Sewerage District planning area, Wis. Site abbreviations listed in table 1. 

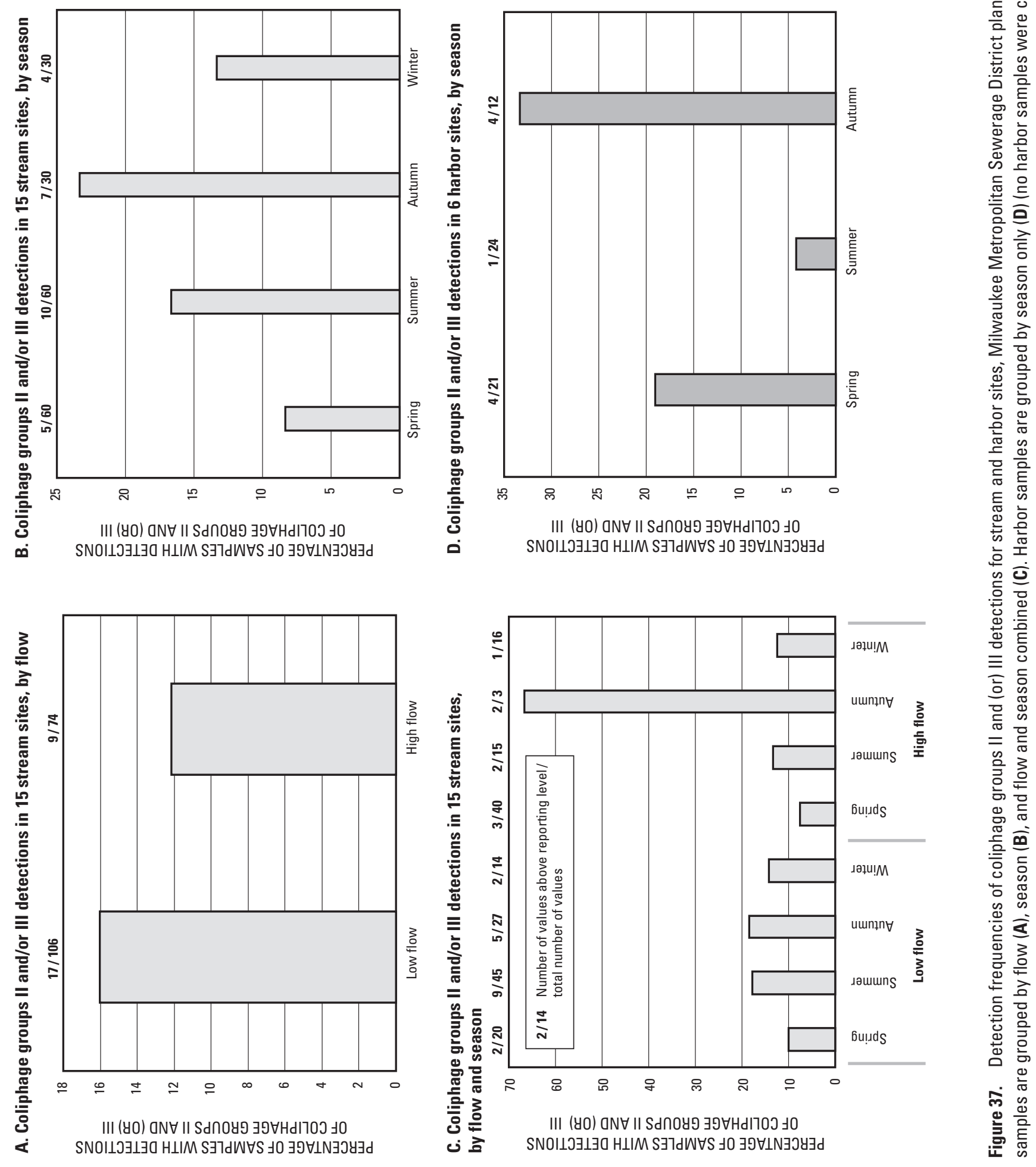


\section{Pathogenic Organisms}

Although indicator organisms are often used as predictors of pathogen presence, pathogen concentrations can also be measured directly. Direct measurement is generally not done for routine monitoring efforts because of practical considerations; however, it was included in the Phase II design because historical pathogen-level data were lacking in the MMSD Corridor Study database.

The waterborne pathogens of interest during Phase II of the MMSD Corridor Study were bacterial, viral, and protozoal. Four common waterborne pathogens were chosen for direct measurement in Phase II: bacterial pathogens were E. coli $\mathrm{O} 157: \mathrm{H} 7$ and Salmonella and protozoal pathogens were Giardia and Cryptosporidium. Viral pathogen concentrations were not measured directly in Phase II but will be measured directly during Phase III of the MMSD Corridor Study.

Pathogens are generally present at substantially lower concentrations in water than indicator organisms are (Mara and Horan, 2003). As a result, detections are less frequent and concentrations are much lower than those associated with indicator organisms. Therefore, pathogen data are discussed in terms of detection frequencies (DF); if concentrations were reported for pathogens, the medians (where possible) and (or) ranges also are given. Because pathogen data were not present in the Phase I database, no comparisons of Phase I and Phase II data are possible.

\section{Escherichia coli 0157:H7}

E. coli $\mathrm{O} 157: \mathrm{H} 7$ causes dysentery and hemolytic uremic syndrome in infected humans. The infective dose for this strain is believed to be fewer than 100 organisms (Percival and others, 2004). Reservoirs for this bacterium include humans and domestic animals. Because E. coli O157:H7 has not been shown to replicate in the environment, its presence is thought to be strictly related to fecal contamination. E. coli O157:H7 can survive in environmental waters for up to 21 days, but it is sensitive to chlorination treatment. Results for E. coli $\mathrm{O} 157: \mathrm{H} 7$ were reported as presence-absence and are discussed herein as number and frequency of detections.

E. coli $\mathrm{O} 157: \mathrm{H} 7$ was detected in 6 of the 237 samples collected during Phase II. All 6 detections were in samples from 5 stream sites (constituting 3 percent of samples). The site with two detections (DF of 17 percent) was the Menomonee River at Menomonee Falls site. The Underwood Creek, Milwaukee River at Mouth, Root River near
Franklin, and Jewel Creek sites each had a single detection (DF of 8 percent). DFs indicated no appreciable relation to urban land use. Five detections occurred during low flow, and four of those occurred during summer.

\section{Salmonella}

Salmonella are a genus of common pathogenic bacteria that can cause gastroenteritis, enteric fever, and septicemia in infected humans. Sources of this group of bacteria are wild and domestic animals including cattle, swine, dogs, cats, birds, and humans. Salmonella have shown the ability to survive in environmental waters for prolonged periods; during warm months, they may be able to replicate in eutrophic waters. Although evidence suggests that Salmonella are less sensitive to disinfection techniques than coliforms, chlorination is effective in inactivating this group of bacteria. Previous studies have found Salmonella in 80 percent of activated sludge effluent from wastewatertreatment plants and in 58 percent of contaminated surface waters (Percival and others, 2004).

For Phase II of the MMSD Corridor Study, analysis for determination of Salmonella concentrations involved concentration enrichment and selective growth techniques, followed by serological testing and confirmation using polyvalent "O" antisera (U.S. Environmental Protection Agency, 2006a). Detectable concentrations of the bacterium were observed in 22 percent of samples. Given the large percentage of concentrations below the reporting levels ( 0.1 and $0.2 \mathrm{MPN} / 100 \mathrm{~mL})$; detectable concentrations were considered too scarce to be analyzed in terms of overall medians. Data are discussed instead as the frequency of Salmonella detections in samples and the medians (where possible) or ranges in concentrations in samples with detectable concentrations. 


\section{Detection Frequencies}

All 58 detections of Salmonella during Phase II were in stream samples (constituting 29 percent of the stream samples collected). No detections were observed in harbor samples, and this may be due to organism die-off or dilution when mixing with water from Lake Michigan. At least one detection of Salmonella was found at every stream site (fig. 38). Nine of the 15 stream sites had DFs greater than or equal to 33 percent; highest DFs (50 percent) were in samples from the Menomonee River at Menomonee Falls, Menomonee River at Wauwatosa, and Root River at Grange Avenue sites. DFs at remaining sites ranged from 8 to 17 percent. DFs indicated no appreciable relation to urban land use.
DFs indicated consistent responses in relation to flow and season. The DF for low-flow-event samples (23 percent) was much lower than that for high-flow-event samples (39 percent)(fig. 39A). The frequency of detection in spring samples (40 percent) was nearly twice as high as those throughout the rest of the year (23 to 25 percent) (fig. 39B). When flow was combined with seasonality, DFs for corresponding seasons were generally higher for highflow events than for low-flow events (fig. 39C). The only exception to this general pattern was the frequency for autumn high-flow-event samples; this category, consisted of only three samples, none of which contained detectable concentrations of Salmonella. High-flow-event samples collected during spring (48 percent) and summer (40 percent) had the highest overall DFs, and, with the exception of the autumn high-flow-event sample, DFs for remaining high- and low-flow seasonal events ranged from 20 to 26 percent.

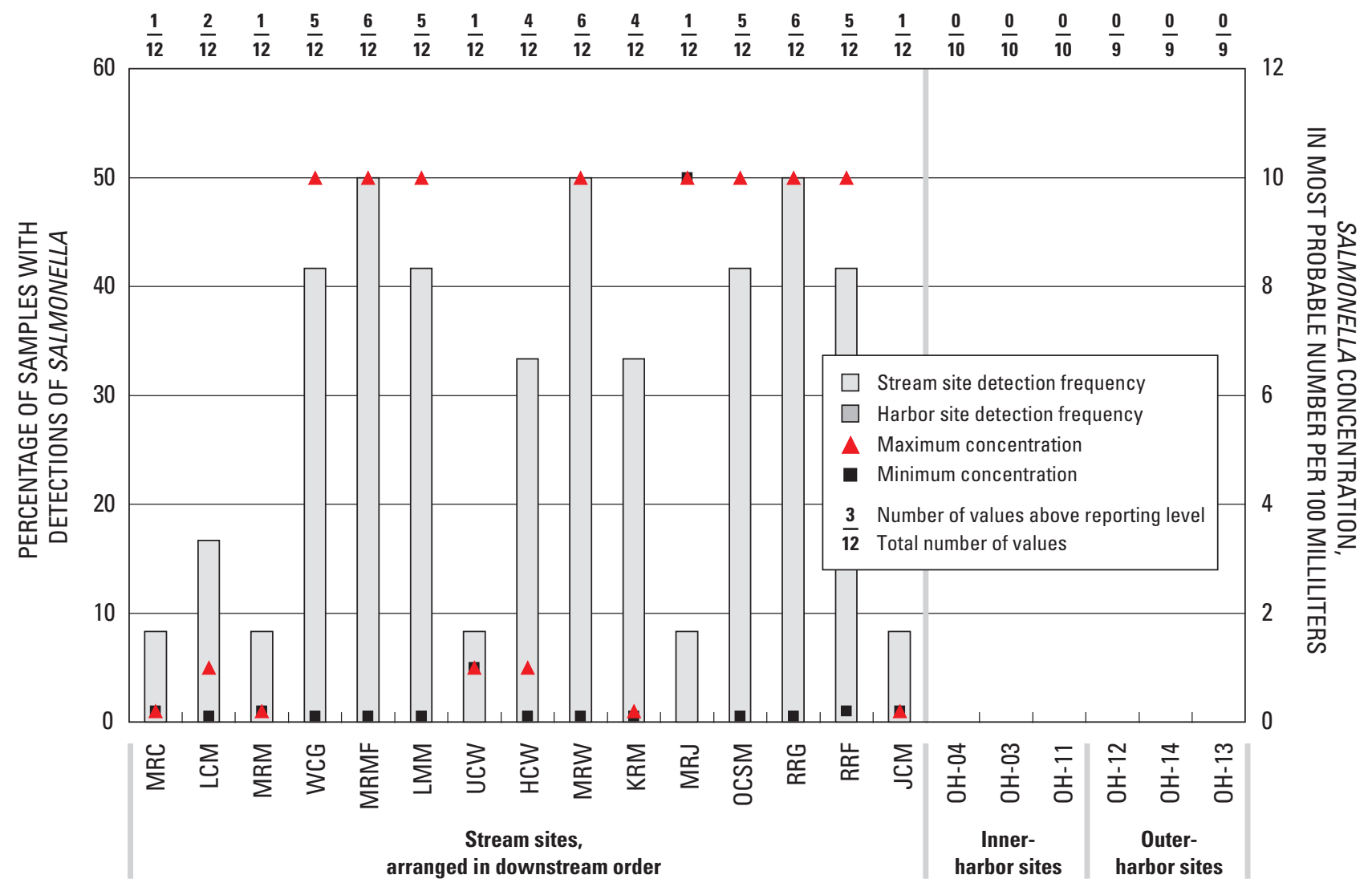

Figure 38. Detection frequencies and concentrations of Salmonella in samples, by site, in the Milwaukee Metropolitan Sewerage District planning area, Wis. Site abbreviations listed in table 1. 

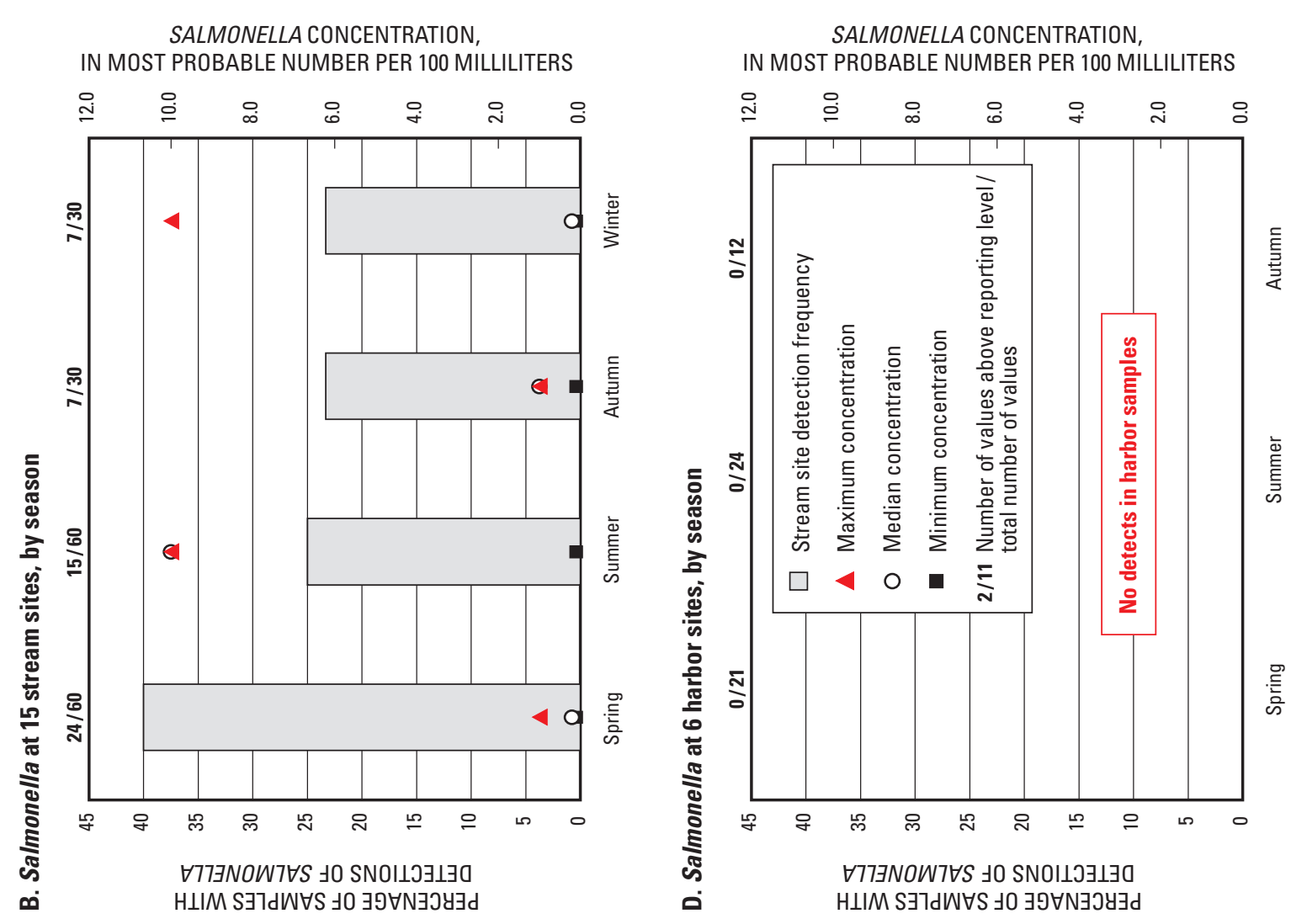

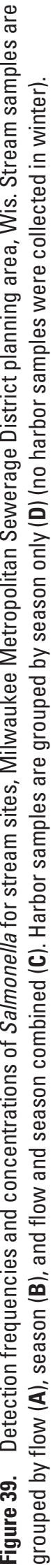
IN MOST PROBABLE NUMBER PER 100 MILLILITERS
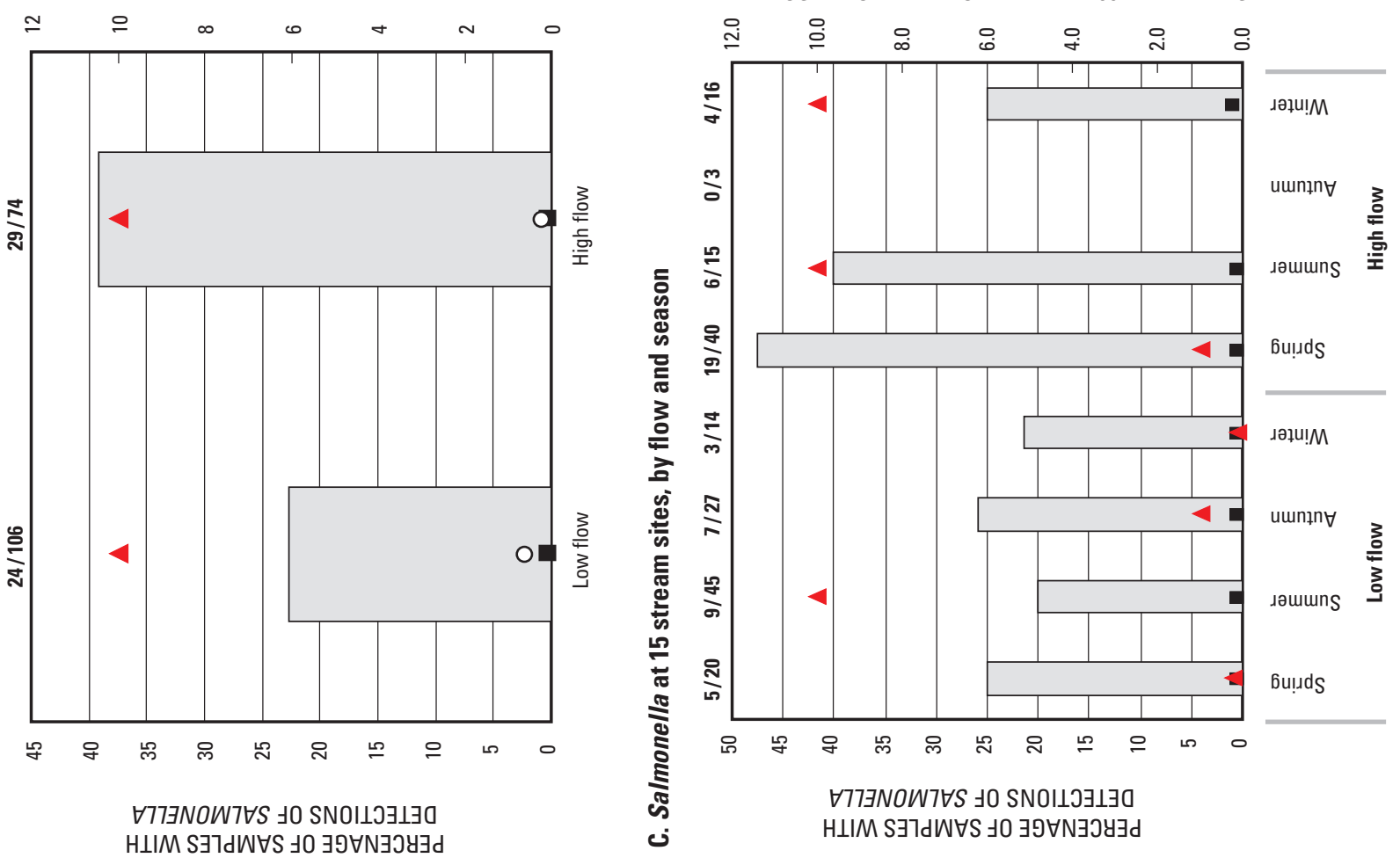


\section{Concentrations}

Salmonella concentrations greater than reporting levels were found only at stream sites. Concentrations ranged from 0.1 to $10 \mathrm{MPN} / 100 \mathrm{~mL}$ (fig. 38), and the median concentration was $0.2 \mathrm{MPN} / 100 \mathrm{~mL}$. Samples containing the highest maximum concentration observed, $10 \mathrm{MPN} / 100 \mathrm{~mL}$, were collected at eight sites: Willow Creek, Menomonee River at Menomonee Falls, Little Menomonee River, and Menomonee River at Wauwatosa, Milwaukee River at Mouth, Oak Creek, Root River at Grange Avenue, and Root River near Franklin.

There was little relation between the variability in Salmonella concentrations and flow or season. Differences between median concentrations for two flow-event conditions were very small, with medians of $0.6 \mathrm{MPN} / 100 \mathrm{~mL}$ for low-flow samples and $0.2 \mathrm{MPN} / 100 \mathrm{~mL}$ for high-flow samples (fig. 39A). The seasonal medians were highest in summer samples (10 MPN/100 mL) and the lowest in spring and winter samples (both $0.2 \mathrm{MPN} / 100 \mathrm{~mL}$ ) (fig. 39B). When flow was combined with seasonality, highest maximum concentrations (10 MPN/100 mL) were found in samples collected during summer low- and high-flow events and winter high-flow events (fig. 39C).

\section{Giardia}

Giardia is a genus-level classification that refers to multiple types of protozoa. Only one species, Giardia duodenalis, infects humans. This species is a common waterborne protozoal pathogen that can cause severe diarrhea and malabsorption. Sources of Giardia include livestock, dogs, cats, beavers, guinea pigs, and humans. Giardia is released from host animals in the environmentally resistant cyst form. These cysts have been shown to maintain viability for up to 3 months in cold environments and to resist disinfection techniques that successfully remove bacteria and viruses. With the exception of response to ultraviolet radiation, Giardia cysts are generally more sensitive than Cryptosporidium oocysts. An infecting dose of 10-25 cysts has been observed in experimental infection studies (Percival and others, 2004).

For Phase II, analysis for Giardia concentrations involved filtration, flow cytometry, and fluorescent antibody microscopy (U.S. Environmental Protection Agency, 2006a). This method detects Giardia to the genus level only (U.S. Environmental Protection Agency, 2005a); therefore, reported results do not specifically refer to levels of Giardia duodenalis. Reporting levels for data in this data set varied greatly, ranging from 30 to 80 cysts/100 L. Concentrations above reporting levels were observed in 26 percent of the samples collected. Given the large percentage of concentrations below the reporting levels, detectable concentrations were considered too scarce to be analyzed in terms of overall medians. Data were reported instead as the frequency of Giardia detections in samples and the medians (where possible) or ranges in concentrations in samples with detectable concentrations.

\section{Detection Frequencies}

Giardia was detected in 27 percent of stream samples and in at least two samples (17 percent) from every site (fig. 40). The highest DF was in samples from Root River near Franklin (42 percent). Lowest DFs (17 percent) were in samples from Lincoln Creek, Milwaukee River at Milwaukee, Honey Creek, and Kinnickinnic River. DFs at remaining sites ranged from 25 to 33 percent. DFs indicated no appreciable relation to urban land use.

DFs were related to flow and season. DFs at stream sites were slightly higher in samples collected during high-flow events ( 28 percent) than during low-flow events (26 percent)(fig. 41A). The highest DFs in stream samples were in winter (50 percent) and spring (32 percent); summer and autumn samples had identical DFs of 17 percent (fig. 41B). When flows were combined with seasonality, DFs at stream sites were not consistently lower during low-flow events when compared to high-flow events for corresponding seasons (fig. 41C); however, winter and summer samples had higher DFs than samples collected at other times of the year during the same flow condition.

DFs at harbor sites (23 percent) were lower than those at stream sites (27 percent), and may be due to organism die-off or dilution when mixing with water from Lake Michigan. Inner-harbor sites had the highest DFs: the South Mid-Harbor Milwaukee Outer Harbor (OH-11) (50 percent), Middle Mid-Harbor Milwaukee Outer Harbor (OH-03) (50 percent), and North Mid-Harbor Milwaukee Outer Harbor (OH-04) (20 percent) sites (fig. 40). Giardia was detected in only one sample from among the outerharbor sites (the Northern Outside Harbor Breakwall Lake site, OH-12, DF 11 percent). Harbor samples indicated a seasonal response. Spring samples had the highest frequency of detection (43 percent), followed by summer samples (12 percent), and autumn samples ( 8 percent) (fig. 41D). Samples were not collected from harbor sites in winter. 


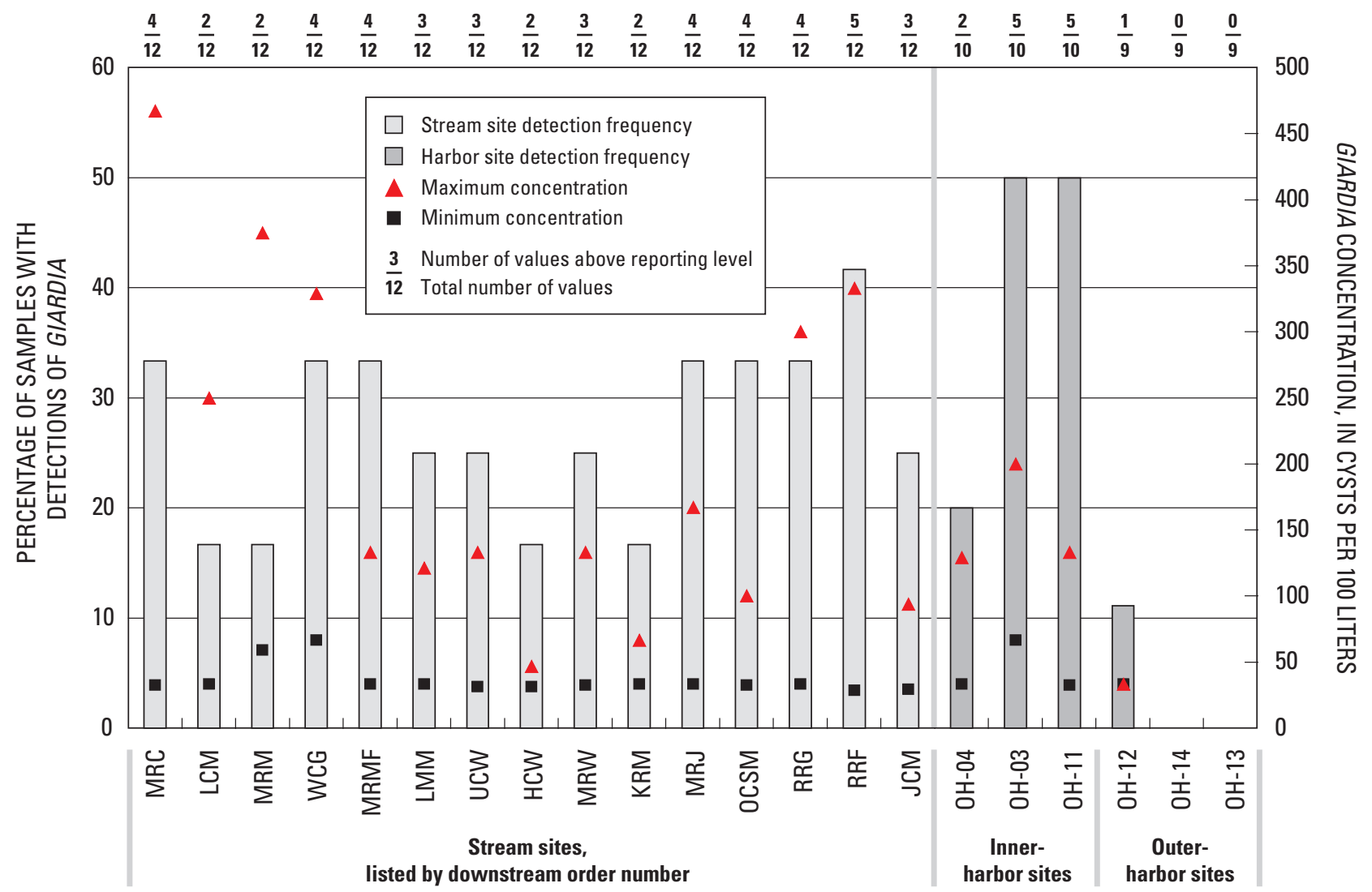

Figure 40. Detection frequencies and concentrations of Giardia in samples by site in the Milwaukee Metropolitan Sewerage District planning area, Wis. Site abbreviations listed in table 1. 

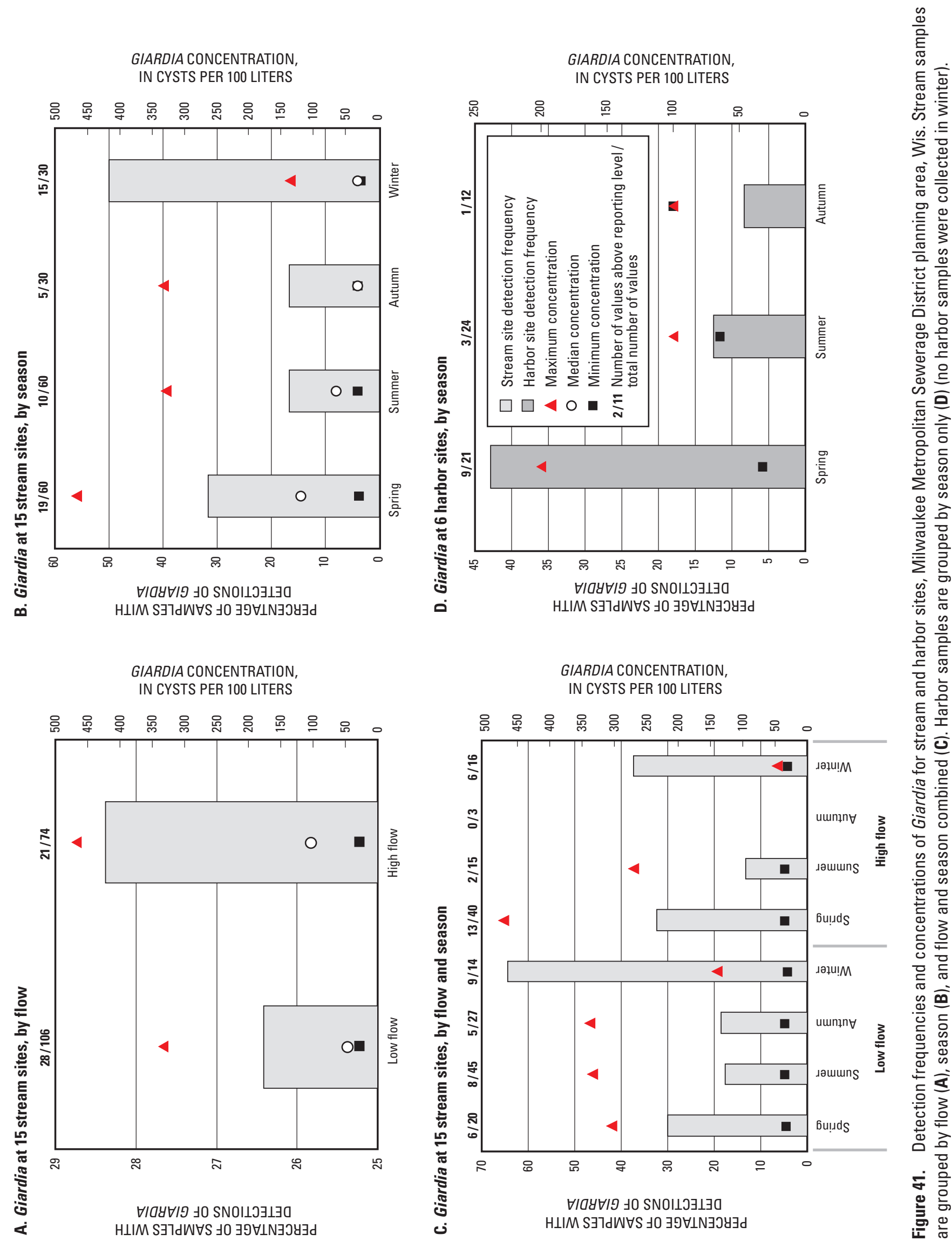


\section{Concentrations}

Giardia concentrations in stream samples ranged from 28.6 to 467 cysts/100 L, with a median of 60.6 cysts/100 L. Sites with the highest maximum concentrations were the Milwaukee River near Cedarburg (467 cysts/100 L), Milwaukee River at Milwaukee (375 cysts/100 L), Root River near Franklin (333 cysts/100 L), Willow Creek (329 cysts/100 L), and Root River at Grange Avenue (300 cysts/100 L) sites (fig. 40).

Concentrations in stream samples indicated consistent responses in relation to flow and season. Stream samples had higher median concentrations during high-flow events (103 cysts/100 L) than during low-flow events (46.1 cysts/100 L) (fig. 41A). The highest median concentrations were in spring-season samples (121 cysts/100 L), followed by summer samples (66.7 cysts/100 L); autumn and winter medians were identical (33.3 cysts/100 L) (fig. 41B). When flows were combined with seasonality, the highest maximum concentration was in a sample collected during a spring high-flow event (467 cysts/100 L) (fig. 41C). Higher maximum concentrations were also observed in low-flow samples collected during autumn (333 cysts/100 L), summer (329 cysts/100 L) and spring (300 cysts/100 L), as well as summer high-flow samples (267 cysts/100 L).

Median Giardia concentrations at harbor sites (100 cysts/100 L) were higher than those at stream sites (60.6 cysts/100 L). Highest maximum concentrations were observed in samples from inner-harbor sites: Middle Mid-Harbor (OH-03) (200 cysts/100 L), South Mid-Harbor (OH-11) (133 cysts/100 L), and North Mid-Harbor (OH-04) (129 cysts/100 L) (fig. 40). The single detection in the outer harbor (at Northern Outside Harbor, OH-12) had a concentration of 33.3 cysts/100 L. Harbor samples indicated a seasonal response (fig. 41D). The maximum concentration in spring samples (200 cysts/100 L) was twice the maximum concentrations in summer and autumn samples (100 cysts/100 L in each).

\section{Cryptosporidium}

Cryptosporidium is a genus-level designation that refers to many protozoal species, some of which are pathogenic to humans. The primary pathogens, however, are generally considered to be $C$. parvum and $C$. hominis. Infection by Cryptosporidium can cause acute effects of diarrhea, abdominal pain, and vomiting; chronic effects include Reiter's syndrome, a reactive arthritis. Reservoirs include humans and animals. Cryptosporidium species are shed in the environmentally resistant oocyst form, which has been shown to maintain viability for as long as 176 days in stream water. Oocysts are resistant to many forms of disinfection, including chlorination. The most effective means of inactivating Cryptosporidium oocysts is through the use of ozone or ultraviolet radiation. An infecting dose of 30 oocysts has been observed in experimental infection studies (Percival and others, 2004).

The analytical method for the determination of Cryptosporidium concentrations involved filtration, flow cytometry, and fluorescent antibody microscopy (U.S. Environmental Protection Agency, 2006a). This method detects Cryptosporidium to the genus level and does not have the specificity to distinguish between different pathogenic and nonpathogenic species; therefore, reported results do not specifically refer to concentrations of pathogenic Cryptosporidium (U.S. Environmental Protection Agency, 2005a). Reporting levels for data varied greatly, ranging from 28.6 to 233 oocysts/100 L; however, the majority of censored results (75 percent) were recorded as less than 33.3 oocysts/100 L. Concentrations above reporting levels were observed in 33 percent of the samples collected. Given the large percentage of results below the reporting levels, concentration data were considered too scarce to be analyzed in terms of overall medians. Data were reported instead as the frequency of Cryptosporidium detections in samples and the medians (where possible) or ranges in concentrations found in samples with detectable concentrations. 


\section{Detection Frequencies}

Cryptosporidium was detected in 42 percent of stream samples and in at least two samples (17 percent) from every site (fig. 42). The highest DFs (both at 58 percent) were from Willow Creek and Menomonee River at Wauwatosa. The lowest DF (17 percent) was from Root River near Franklin. DFs at remaining sites ranged from 25 to 50 percent. DFs indicated no appreciable relation to urban land use.

DFs varied by flow and season. DFs were higher in samples collected during low-flow events (46 percent) than during high-flow events (36 percent)(fig. 43A). The highest frequency of Cryptosporidium detections was in winter samples (70 percent) and the lowest in spring samples (18 percent) (fig. 43B). DFs ranged from 47 to 50 percent throughout the rest of the year. When flows were combined with seasonality, DFs were generally higher during low-flow events than during high-flow events for corresponding seasons (except spring) (fig. 43C). Within each flow category, the highest DFs were in winter samples and the lowest were in spring samples.
The DF of Cryptosporidium at harbor sites (5 percent) was lower than at stream sites ( 42 percent), and may be attributed to organism die-off or dilution from mixing with water from Lake Michigan. Detections in harbor samples only occurred at the northern sites of the inner and outer harbor: North Mid-Harbor (OH-04) (20 percent, 2 samples total) and Northern Outside Harbor (OH-12) (11 percent, 1 sample total) (fig. 42). In relation to seasonality, the harbor samples had one detection per season, with DFs ranging from 4 to 8 percent (fig. 43D).

\section{Concentrations}

Cryptosporidium concentrations in stream samples ranged from 29.4 to 782 oocysts/100 L, with a median of 62.5 oocysts/100 L. The highest maximum concentration was at Willow Creek (782 oocysts/100 L)(fig. 42), and the lowest maximum concentrations (33.3 oocysts/100 L for both) were at Milwaukee River at Mouth and Root River near Franklin. Maximum concentrations at the remaining sites ranged from 66.7 to 286 oocysts/100 L.

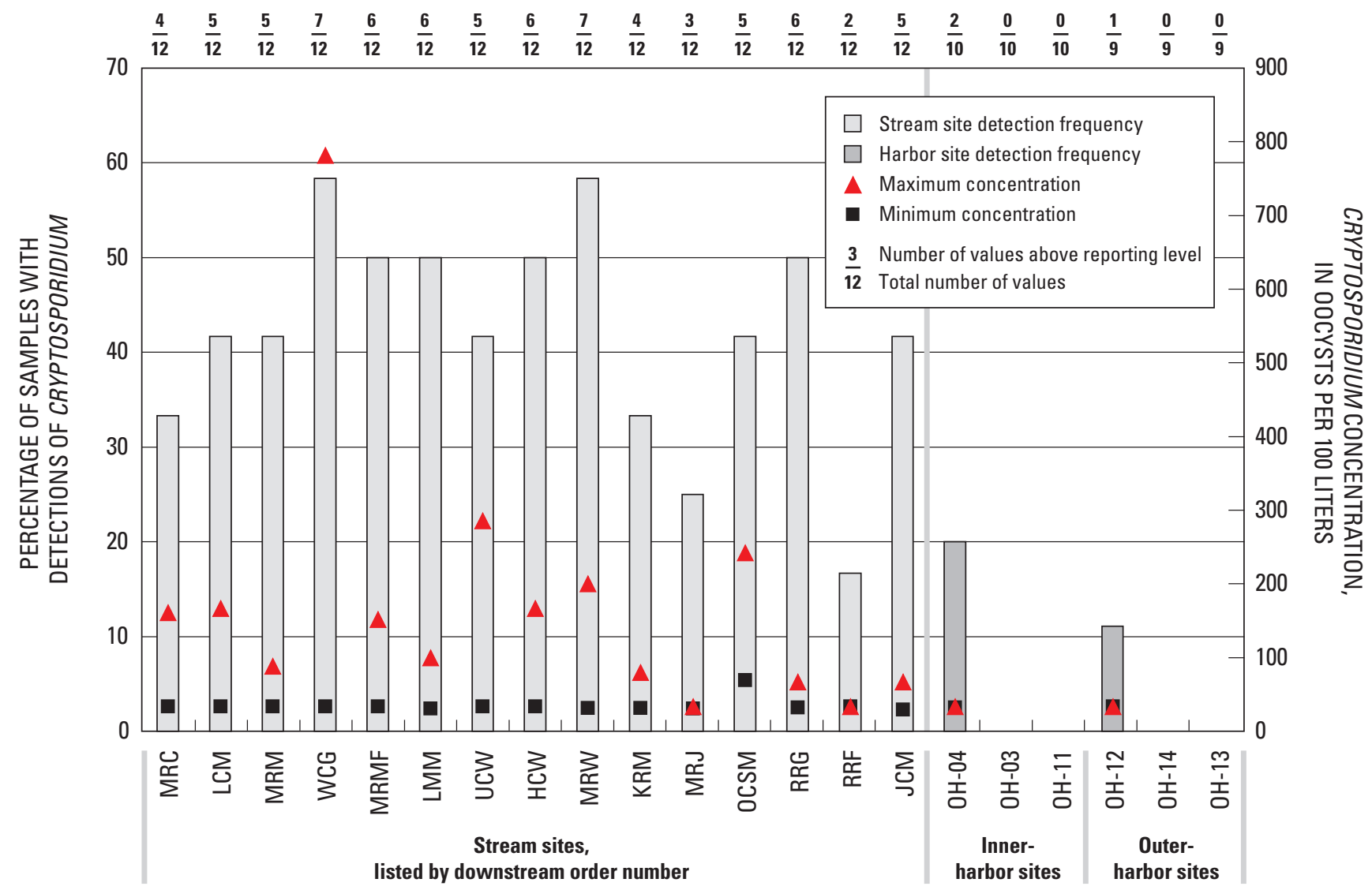

Figure 42. Detection frequencies and concentrations of Cryptosporidium in samples, by site, in the Milwaukee Metropolitan Sewerage District planning area, Wis. Site abbreviations listed in table 1. 
CRYPTOSPORIDIUM CONCENTRATION, IN OOCYSTS PER 100 LITERS

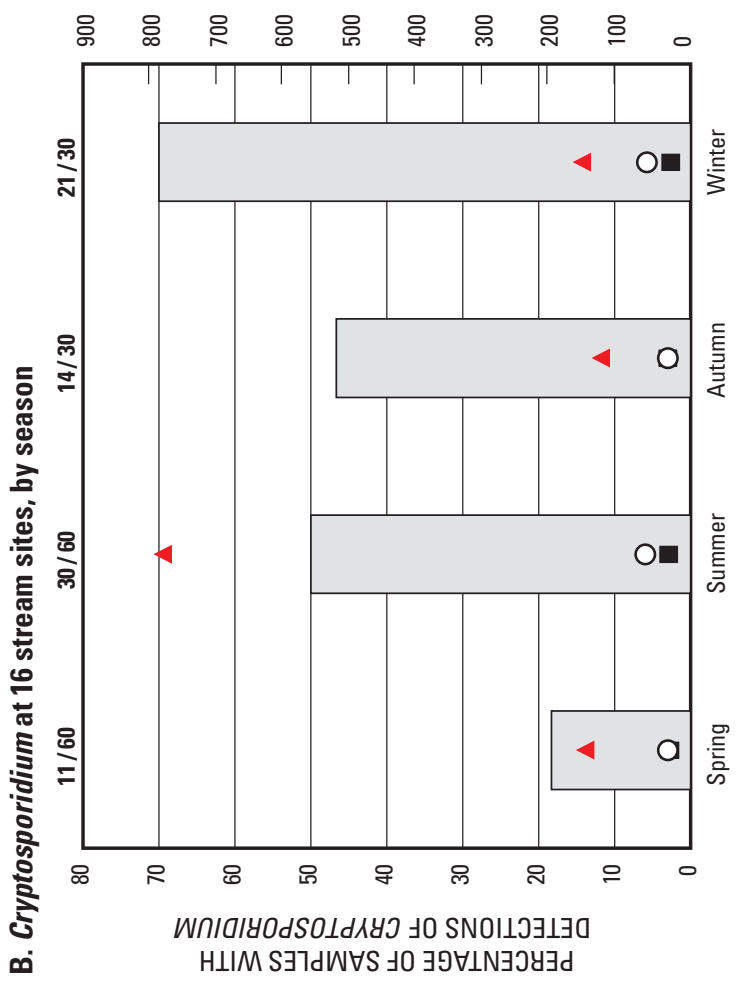

CRYPTOSPORIDIUM CONCENTRATION IN OOCYSTS PER 100 LITERS

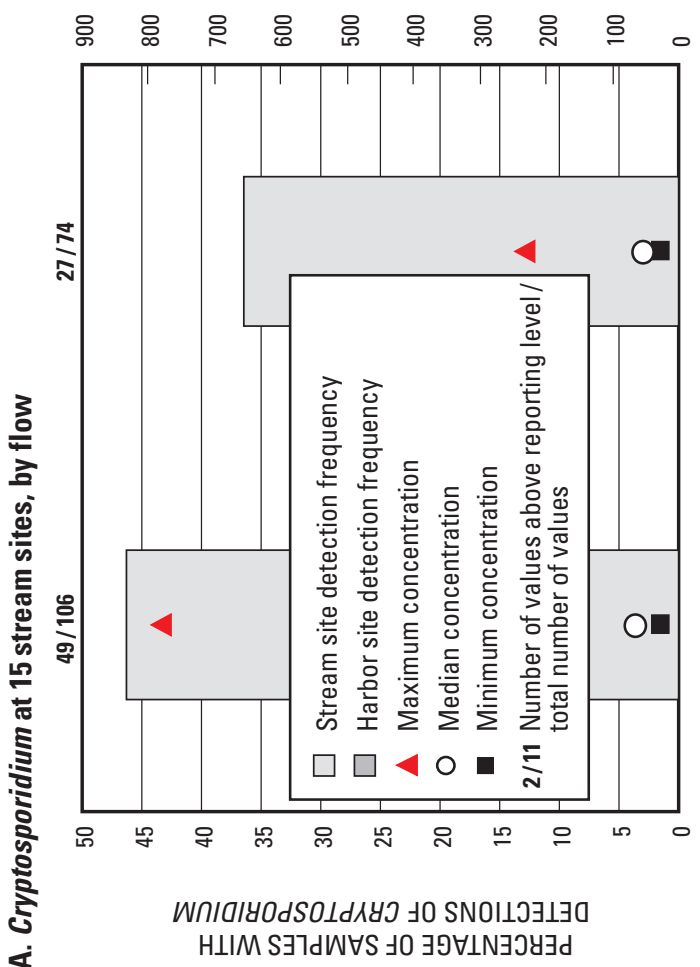

CRYPTOSPORIDIUM CONCENTRATION, IN OOCYSTS PER 100 LITERS

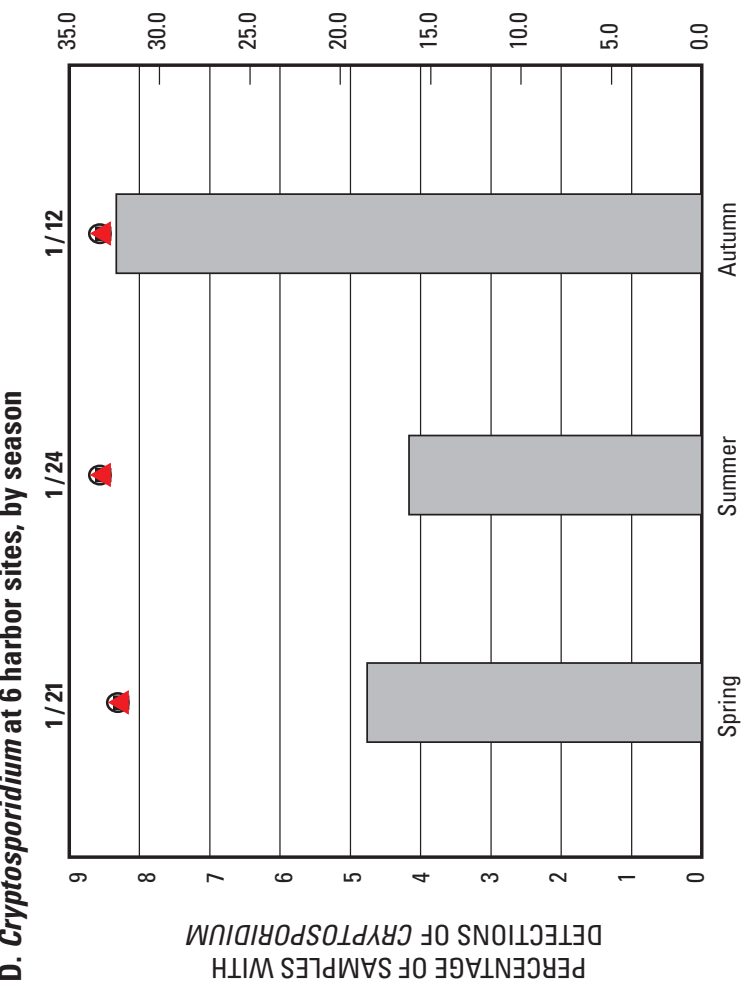

CRYPTOSPORIDIUM CONCENTRATION, IN OOCYSTS PER 100 LITERS

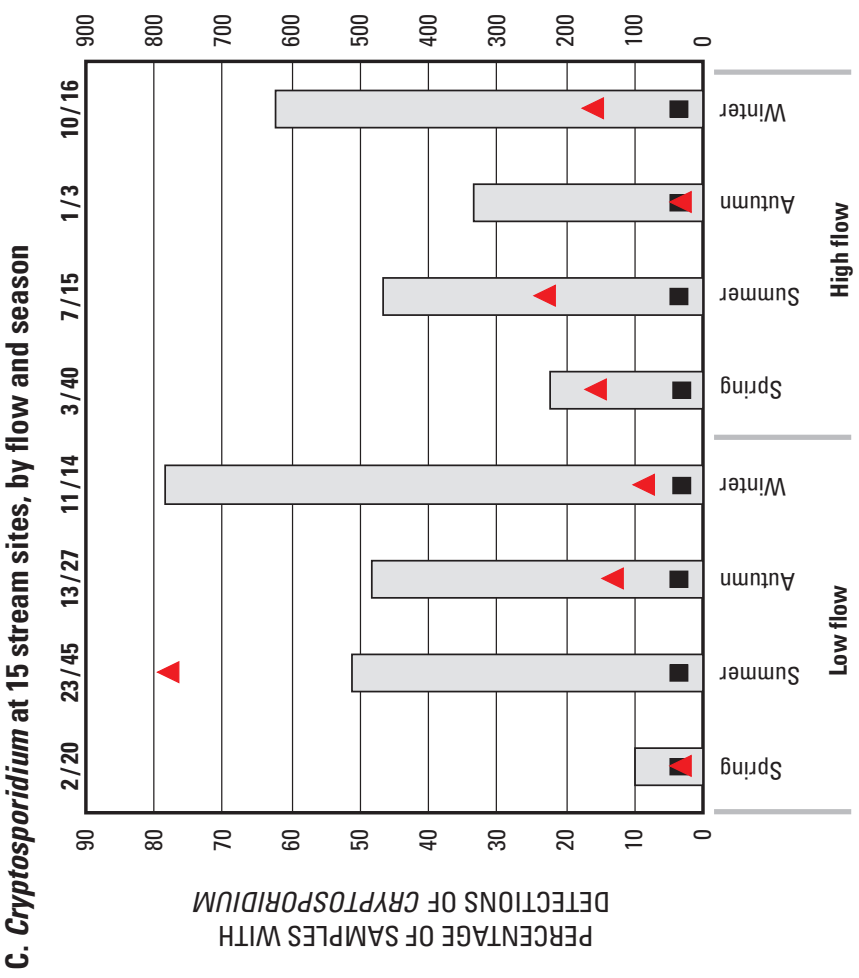

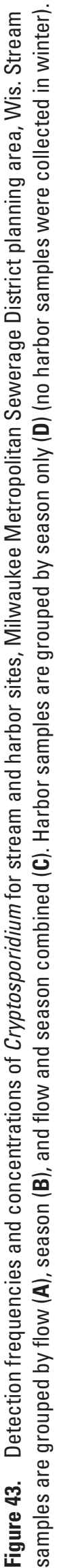


Concentrations indicated consistent responses in relation to flow and season. Median concentrations during low-flow events $(64.5$ oocysts/100 L) were slightly higher than during high-flow events (53.3 oocysts/100 L) (fig. 43A). The highest median concentrations were measured in summer samples (66.7 oocysts/100 L) and winter samples (64.5 oocysts/100 L); spring and autumn samples had identical medians, 33.3 oocysts/100 L (fig. 43B). The maximum concentration for summer samples (782 oocysts/100 L) was much higher than the maximum concentrations in samples for the rest of the year (133 to 161 oocysts/100 L). When flows were combined with seasonality, the highest maximum concentration at stream sites was in a sample collected during a summer low-flow event (782 oocysts/100 L)(fig. 43C). High maximum concentrations were also found in samples collected during highflow events in summer (233 oocysts/100 L), winter (161 oocysts/100 L) and spring (156 oocysts/100 L), as well as autumn low-flow-event samples (133 oocysts/100 L).

The two harbor sites where Cryptosporidium was detected had similar concentrations: North Mid-Harbor (OH-04) (32.3 and 33.3 oocysts/100 L) and Northern Outside Harbor (OH-12) (33.3 oocysts/100 L), which were generally lower than those at stream sites (median concentration of 62.5 oocysts/100 L) (fig. 42). Cryptosporidium concentrations were similar in spring, summer, and autumn (fig. 43D).

\section{Pesticides}

Samples collected each year during spring-quarterly and summer-event sampling were analyzed for pesticides; thereby yielding data for four samples per site. The analytical schedule for pesticides included 41 pesticides and 23 metabolites, or breakdown products (appendix 3). Of the 41 pesticides, 21 were detected in at least one sample. Of the 23 metabolites, 9 were detected in at least one sample. Two pesticides were detected in every sample: atrazine (along with its metabolite 2-chloro-4-isopropylamino-6amino-s-triazine) and metolachlor. Concentrations of all three constituents were generally higher in stream samples than harbor samples. Atrazine concentrations at stream sites ranged from $0.014 \mu \mathrm{g} / \mathrm{L}$ at Honey Creek to $0.95 \mu \mathrm{g} / \mathrm{L}$ at Root River at Grange Avenue, while concentrations at harbor sites ranged from $0.039 \mu \mathrm{g} / \mathrm{L}$ at the Northern Outside Harbor Breakwall Lake site to $0.11 \mu \mathrm{g} / \mathrm{L}$ at the Middle
Mid-Harbor Milwaukee Outer Harbor site. 2-Chloro-4-isopropylamino-6-amino-s-triazine (deethylatrazine) concentrations at stream sites ranged from $0.006 \mu \mathrm{g} / \mathrm{L}$ at Honey Creek to $0.128 \mu \mathrm{g} / \mathrm{L}$ at Root River at Grange Avenue, while concentrations at harbor sites ranged from 0.013 $\mu \mathrm{g} / \mathrm{L}$ at the Northern Outside Harbor Breakwall Lake site to $0.037 \mu \mathrm{g} / \mathrm{L}$ at the Middle Mid-Harbor Milwaukee Outer Harbor site. Metolachlor concentrations at stream sites ranged from $0.014 \mu \mathrm{g} / \mathrm{L}$ at Honey Creek to $0.488 \mu \mathrm{g} / \mathrm{L}$ at Little Menomonee River, while concentrations at harbor sites ranged from $0.008 \mu \mathrm{g} / \mathrm{L}$ at the Northern Outside Harbor Breakwall Lake and Middle Outside Harbor Breakwall Lake sites to $0.02 \mu \mathrm{g} / \mathrm{L}$ at the Middle Mid-Harbor Milwaukee Outer Harbor site. The presence of atrazine, deethylatrazine, and metalochlor in every sample is typical, as these pesticides are among the most heavily used and their presence in streams across the Nation has been well-documented (Gilliom and others, 2006).

Generally, concentrations of pesticides were low. The highest concentration observed was in a sample from Little Menomonee River (7.86 $\mu \mathrm{g} / \mathrm{L}$ of simazine). In that same sample, no other pesticides were present in unusually high concentrations. Remaining samples ranged in concentration from below detection to $2.9 \mu \mathrm{g} / \mathrm{L}$ (bromacil, also at Little Menomonee River). These concentrations were typical of samples collected at fixed intervals and during normal flow conditions. Modern pesticides have moderate to high water solubility and relatively short half-lives. As a result, stream pesticides concentrations are generally highest following rainfall events producing notable runoff, with an enhanced effect when rainfall events occur shortly after pesticide application (Graczyk and others, 1997 and 1999). Selected pesticides will be discussed further in the wastewater compound section, where pesticides are divided into herbicide and insecticide classes. 


\section{Wastewater Compounds}

Wastewater compounds (WWCs) are organic compounds of natural or synthetic origin typically found in domestic and industrial wastewaters. WWCs include many classes of compounds: surfactants, flame retardants, plasticizers, industrial solvents, disinfectants, domestic pesticides, pharmaceuticals, and personal-care products (Zaugg and others, 2002). These compounds and degradates survive wastewater-treatment processes and are expelled into the environment in treated wastewater (Lee and others, 2004). Recent studies of WWCs downstream from wastewater-treatment facilities in Minnesota indicated concentrations twice those observed upstream (Lee and others, 2004). Kolpin and others (2002) found WWCs in 80 percent of U.S. streams sampled, with median concentrations generally less than $1 \mu \mathrm{g} / \mathrm{L}$. Mixtures of compounds were common in the samples collected, with a maximum of 38 and a median of 7 compounds detected in samples. WWCs have also been detected in drinking water (Lee and others, 2004).

A subset of WWCs analyzed for in Phase II consist of substances known to or are suspected to disrupt endocrine function in vertebrate organisms. Termed endocrine-disrupting chemicals (EDCs), these compounds are defined by the USEPA (U.S. Environmental Protection Agency, 1997) as

“. . . an exogenous agent that interferes with the synthesis, secretion, transport, binding, action, or elimination of natural hormones in the body that are responsible for the maintenance of homeostasis, reproduction, development, and (or) behavior."
Though few causal relations have been conclusively established between EDCs and adverse effects in vertebrates under environmental conditions, effects on test organisms in controlled laboratory settings have been shown (Taylor and Harrison, 1999; Kaiser, 2000). In contrast to most toxic chemicals, effects on test organisms have been seen at very low EDC concentrations, well below concentrations typically considered "safe" (Kaiser, 2000). To date, most studies have focused on the effects of a single compound; toxic effects of chemical mixtures are not known (Sullivan and others, 2005). It is thought that long-term, continual exposure to EDCs may have subtle effects on vertebrate populations over time through adverse effects on reproduction (Daughton and Ternes, 1999).

As part of Phase II, samples were collected and analyzed for WWCs, which included pharmaceuticals and personal-care products. WWC samples were collected during each sampling event, resulting in 12 samples per site.

\section{Detection Frequencies}

As mentioned in the Quality Assurance and Quality Control section, WWC data contain estimated concentrations, concentrations above the reporting level, qualitatively detected results (constituent detected but not quantified), and concentrations less than detection (table 18). Only 3 percent of stream-sample data and 1 percent of harbor-sample data reported had concentrations above the reporting level, and therefore little quantitative analysis could be performed. Results were grouped as detections/ nondetections, where detections of WWCs consisted of estimated concentrations and concentrations above the reporting level.

Table 18. Summary of detections and nondetections of wastewater compounds at all Phase II sites in the Milwaukee Metropolitan Sewerage District planning area, Wis.

[All values in percent]

\begin{tabular}{ccccccc}
\hline \multirow{2}{*}{ Site type } & \multicolumn{2}{c}{ Nondetections } & & \multicolumn{2}{c}{ Detections } \\
\cline { 2 - 3 } \cline { 6 - 7 } & $\begin{array}{c}\text { Less than } \\
\text { detection }\end{array}$ & $\begin{array}{c}\text { Qualitatively } \\
\text { detected }\end{array}$ & & $\begin{array}{c}\text { Estimated } \\
\text { concentrations }\end{array}$ & $\begin{array}{c}\text { Concentrations above } \\
\text { reporting level }\end{array}$ \\
${$\cline { 2 - 3 }$} }$ & 69 & 14 & & 15 & 3 & 1 \\
Harbor samples & 78 & 14 & & 7 & 3 \\
\hline
\end{tabular}


A total of 62 WWCs were sampled for and were aggregated into classes for the purpose of analysis (tables 19 and 20). The 15 classes of WWCs were based on aggregations by Sullivan and others (2005), appendix 4-3 p. 353. WWC classes were organized into four groups in an effort to identify sources of WWC contribution to stream and harbor sites (table 19). At the site level, these groupings aided in the understanding of the persistence of WWC classes as they moved from stream sites to harbor sites, distribution of WWC classes, and relations between WWC classes. The 15 classes aided in the understanding of WWC response to flow, seasonality, and the combined effects of flow and seasonality. These groups were also used to organize information regarding the individual constituents driving detections and (or) responses in each class.

Table 19. Grouping of wastewater-compound (WWC) classes for Phase II of the Milwaukee Metropolitan Sewerage District Corridor Study.

[PAH, polycyclic aromatic hydrocarbon]

\begin{tabular}{|c|c|}
\hline Class & $\begin{array}{c}\text { Number of } \\
\text { constituents }\end{array}$ \\
\hline \multicolumn{2}{|l|}{ Group 1} \\
\hline Antioxidants & 3 \\
\hline Dyes and pigments & 1 \\
\hline Fire retardants & 3 \\
\hline PAHs & 3 \\
\hline Plasticizers & 6 \\
\hline \multicolumn{2}{|l|}{ Group 2} \\
\hline Fuels & 4 \\
\hline Solvents & 3 \\
\hline \multicolumn{2}{|l|}{ Group 3} \\
\hline Herbicides & 5 \\
\hline Insecticides & 6 \\
\hline \multicolumn{2}{|l|}{ Group 4} \\
\hline Antimicrobial disinfectants & 2 \\
\hline Detergent metabolites & 7 \\
\hline Flavors and fragrances & 10 \\
\hline Human drugs (nonprescription) & 3 \\
\hline Sterols & 2 \\
\hline Miscellaneous & 4 \\
\hline
\end{tabular}

Of the 62 constituents sampled for during Phase II, 50 were detected in at least one sample collected from the stream or harbor. The 12 constituents not detected in any sample vary in WWC class and indicated no particular pattern (table 20). Forty-nine constituents were detected in at least one stream sample. The only constituent not detected in streams that was detected in harbor samples was chlorpyrifos, an insecticide. Harbor samples had fewer constituent detections overall, with only 34 constituents detected in one or more samples. The constituents not detected in the harbor samples (table 20) also varied in WWC class; in some cases, there were no detections for an entire WWC class in harbor samples. The two WWC classes not detected in harbor samples were antimicrobial disinfectants and antioxidants. Overall, 93 percent (217 of 234) of both stream and harbor samples contained a minimum of one WWC detection. At stream sites, the number of constituents detected in samples ranged from 1 to 29 , with more than half the samples containing nine or more WWCs. In harbor samples, the number of constituents in samples ranged from 1 to 22 , with over half the samples containing two or more WWCs.

In streams, the most frequently detected class of constituents was herbicides (greater than 90 percent DF), followed by nonprescription human drugs (greater than 80 percent DF) (figs. 44-47). In harbor samples, the most frequently detected class of constituents was flavors and fragrances (greater than 60 percent DF), closely followed by insecticides and solvents.

The sites where several classes of WWCs were detected frequently were Lincoln Creek, Milwaukee River at Mouth, Little Menomonee River, Underwood Creek, and Honey Creek). Of these sites, Kinnickinnic River had the highest detection frequency in the most classes (5 of the 15 WWC classes). No consistent response was observed between any WWC class and land use. 


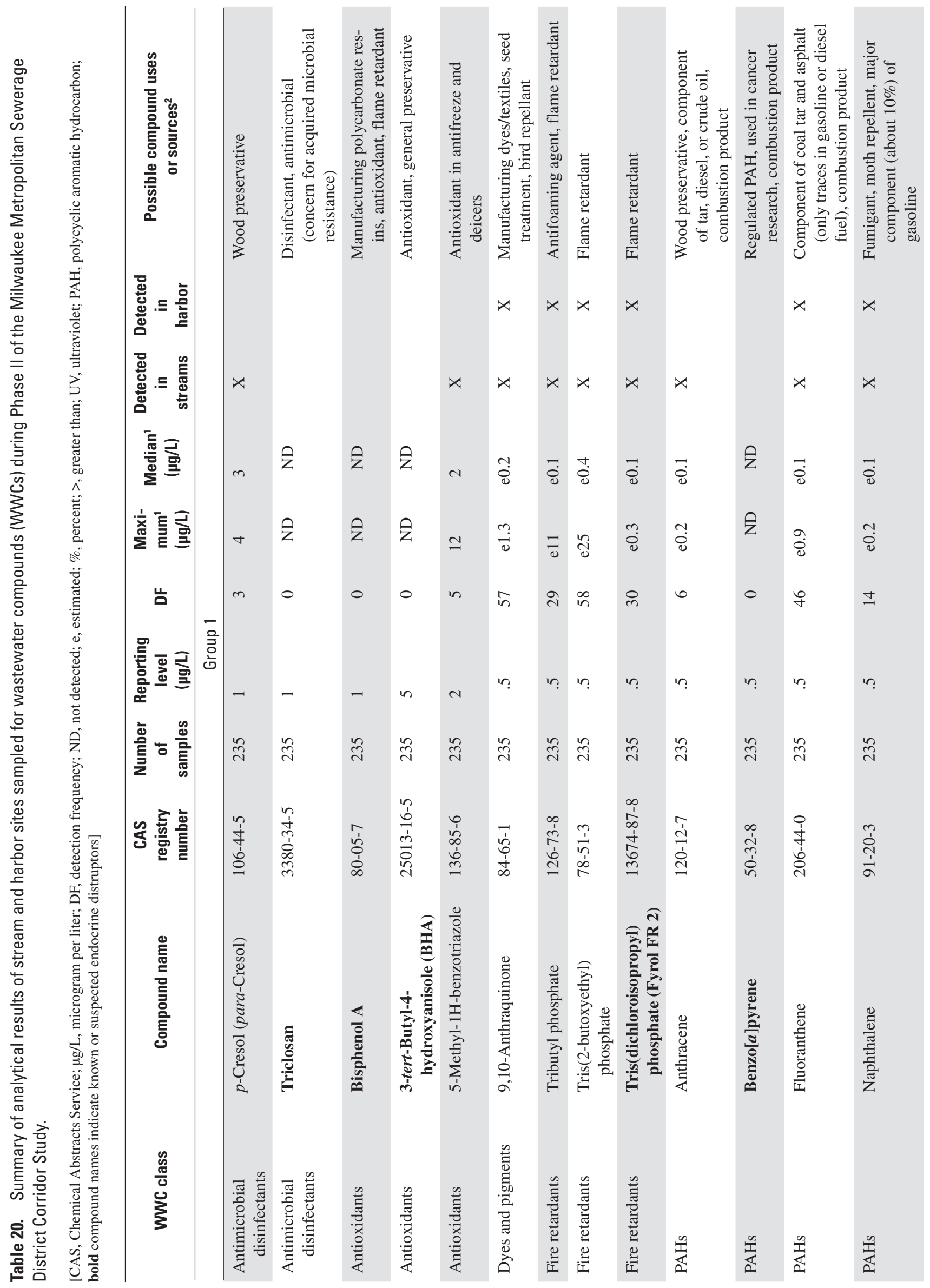




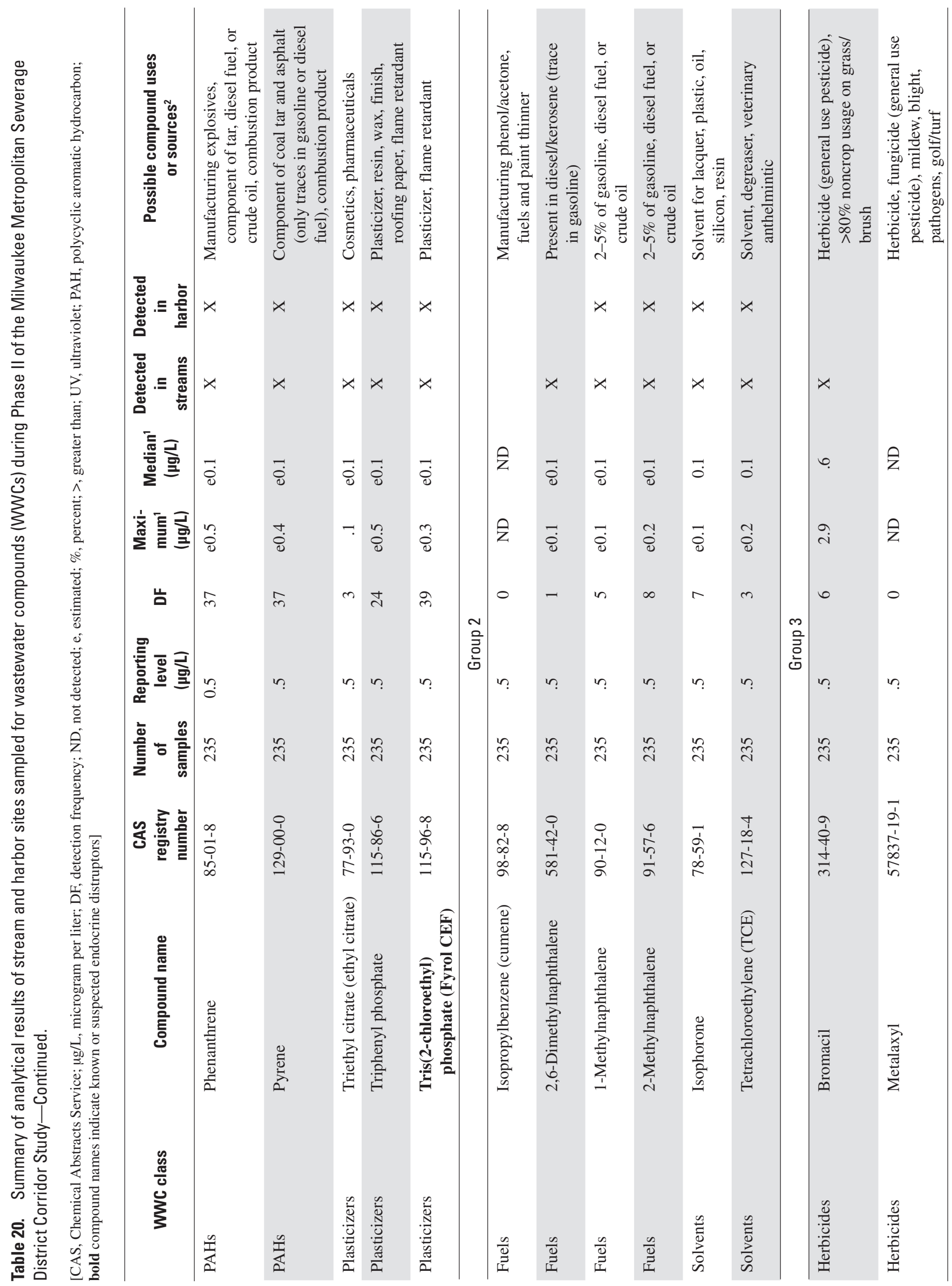




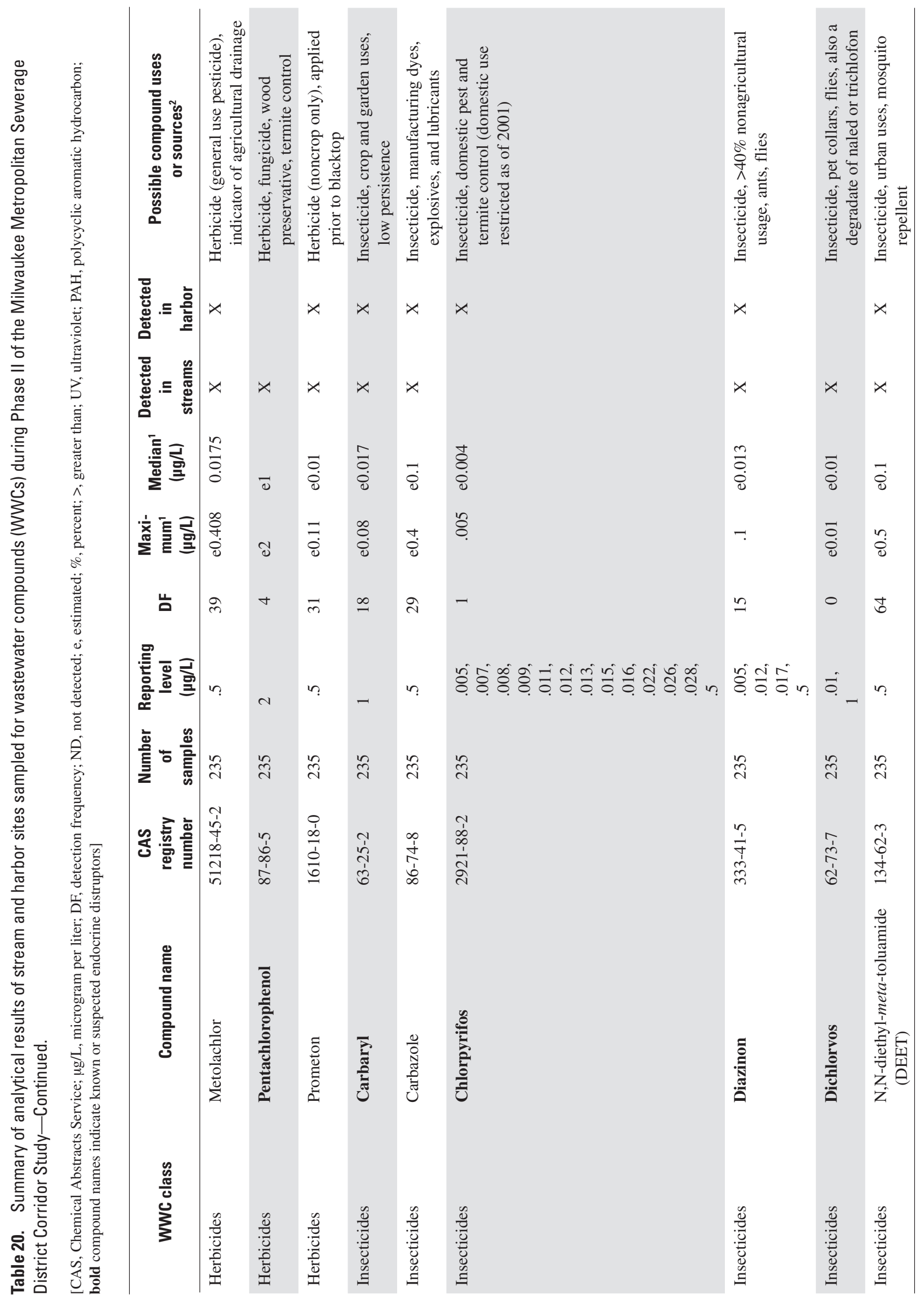




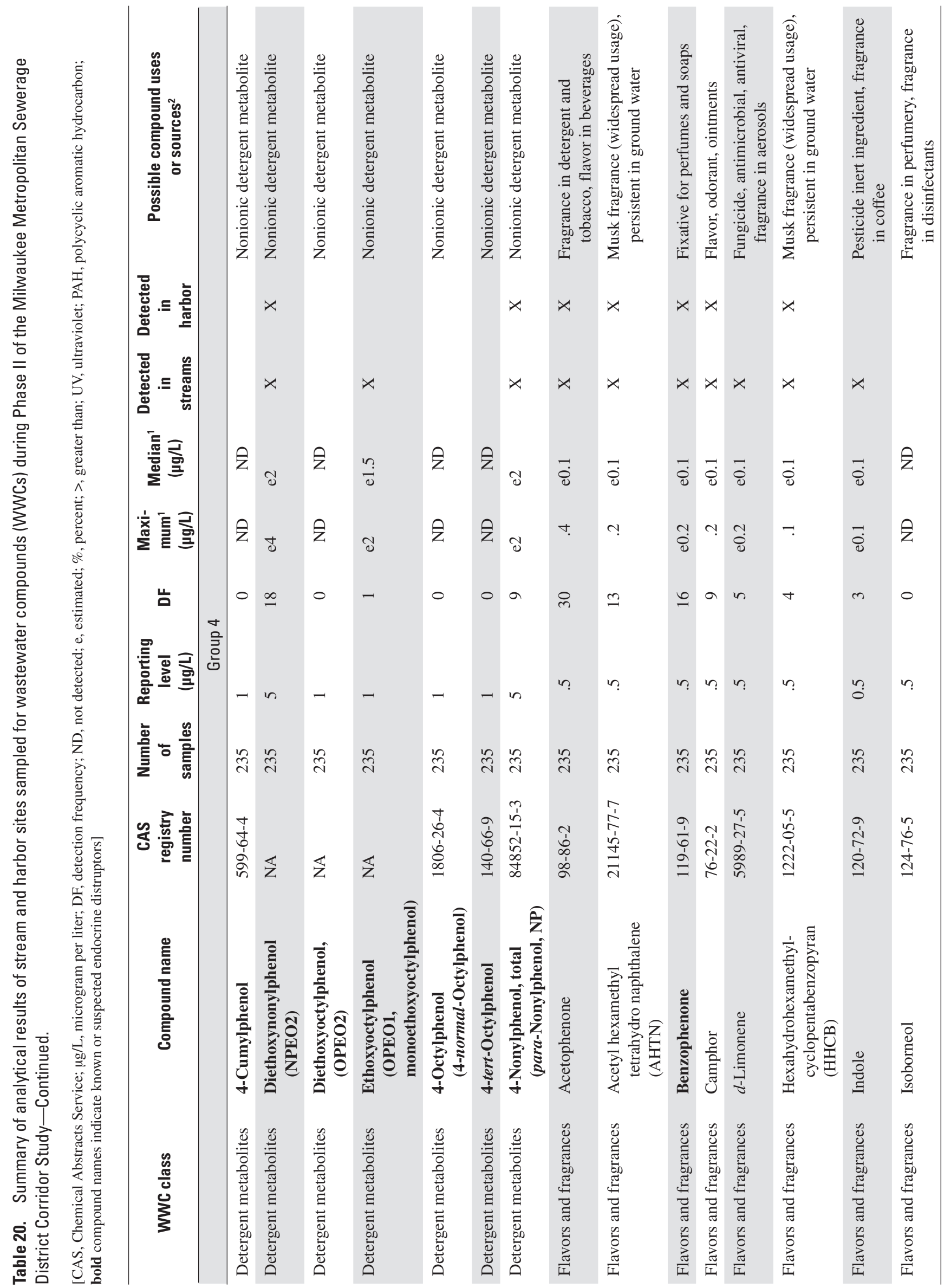




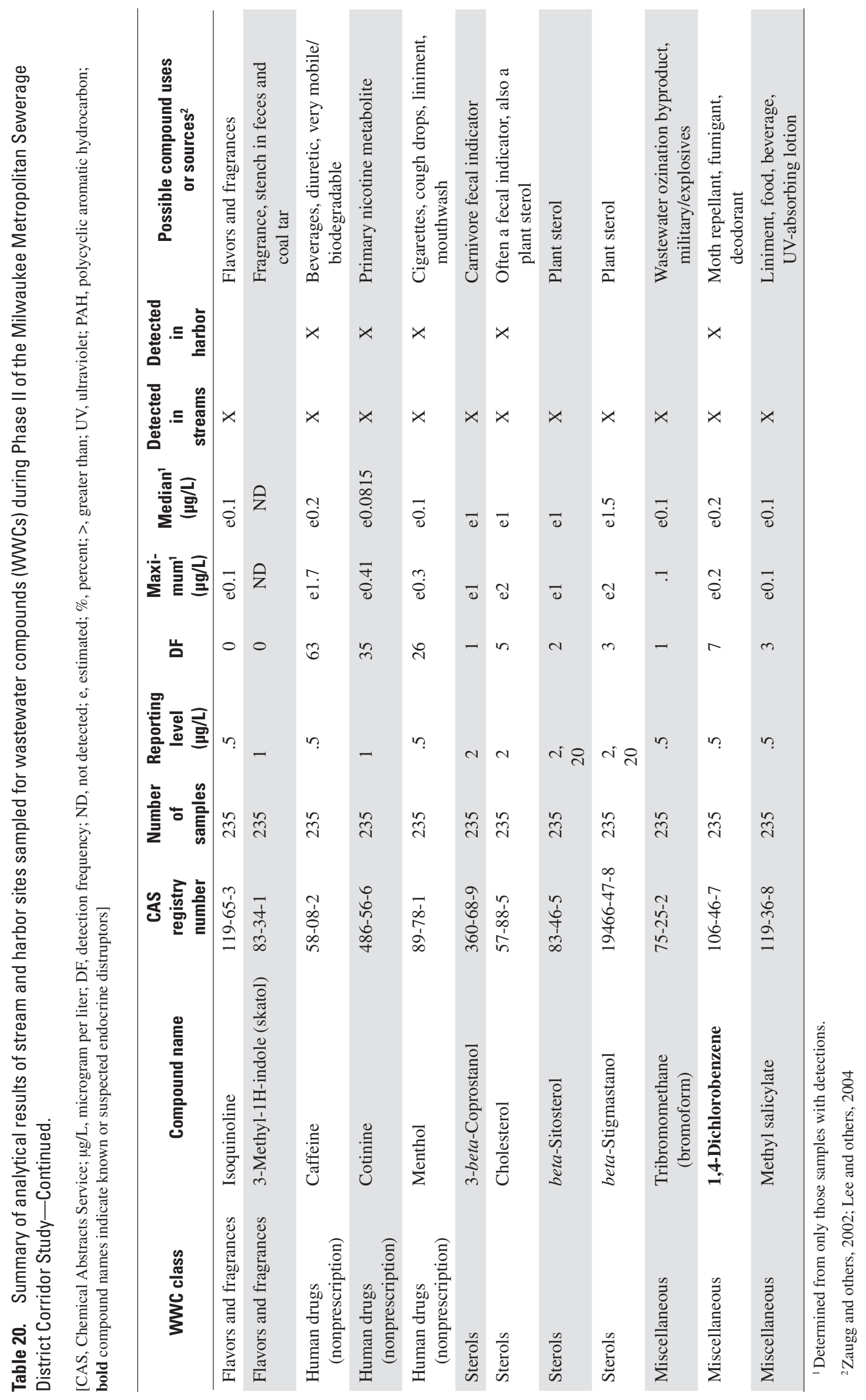




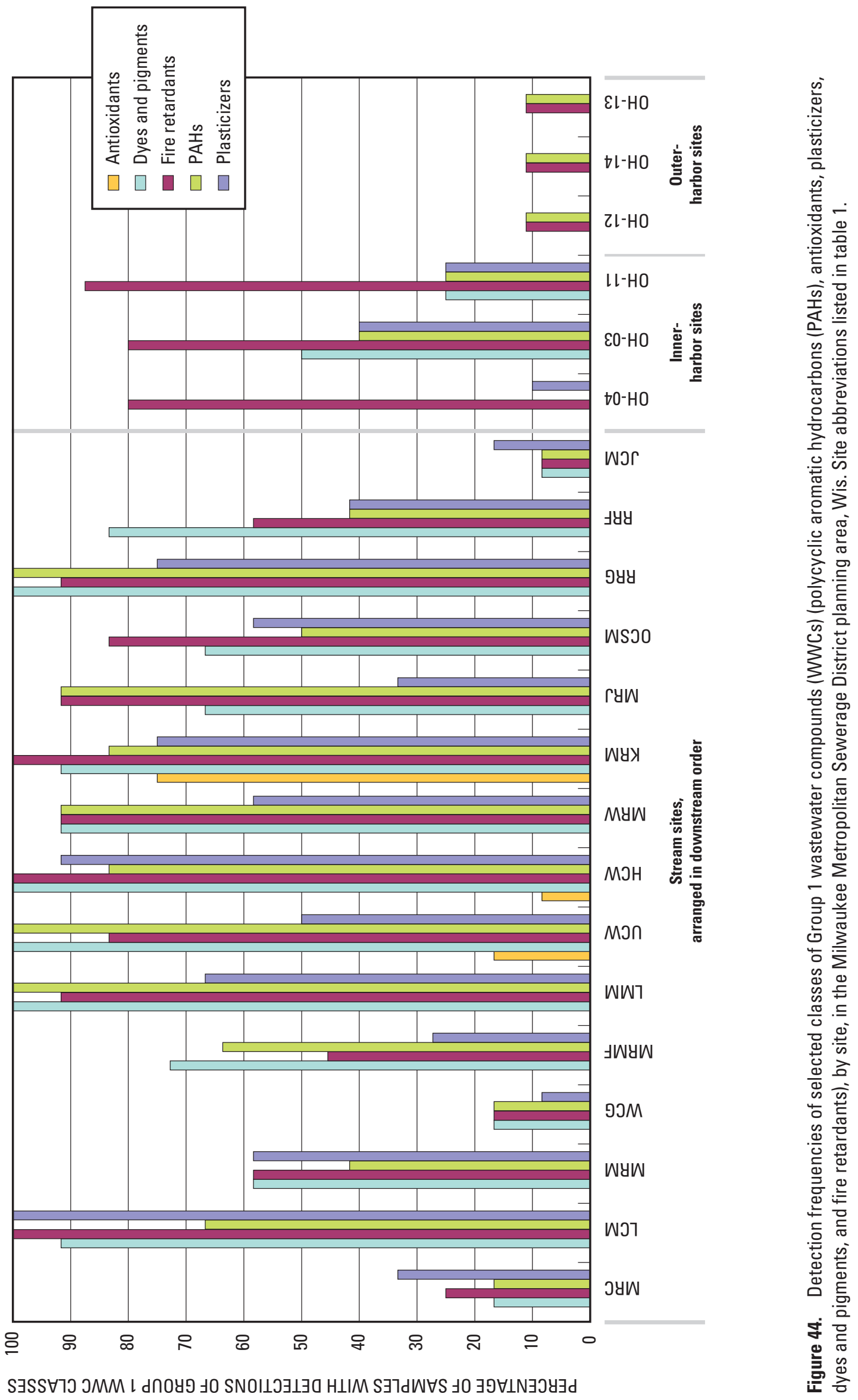




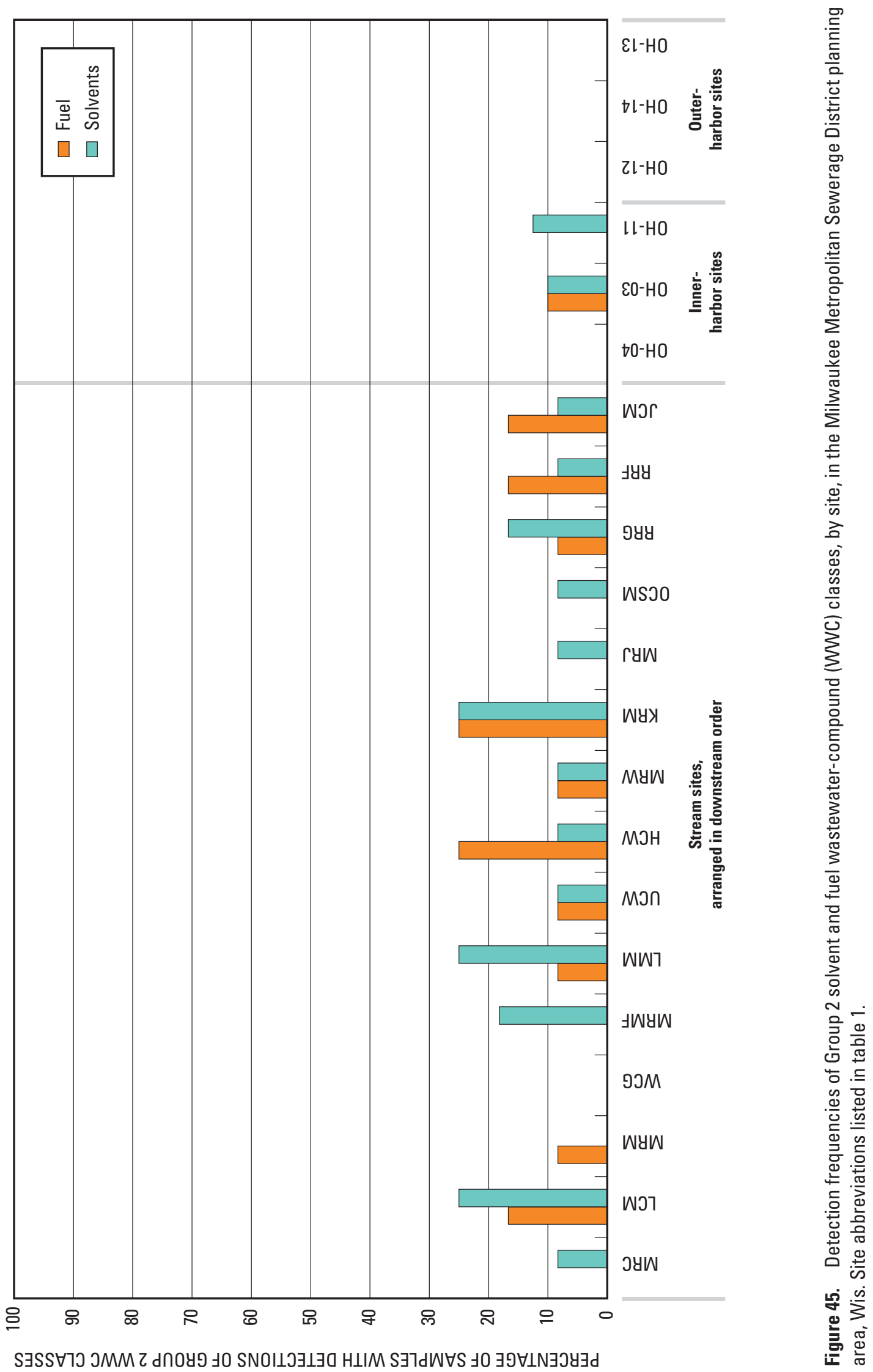




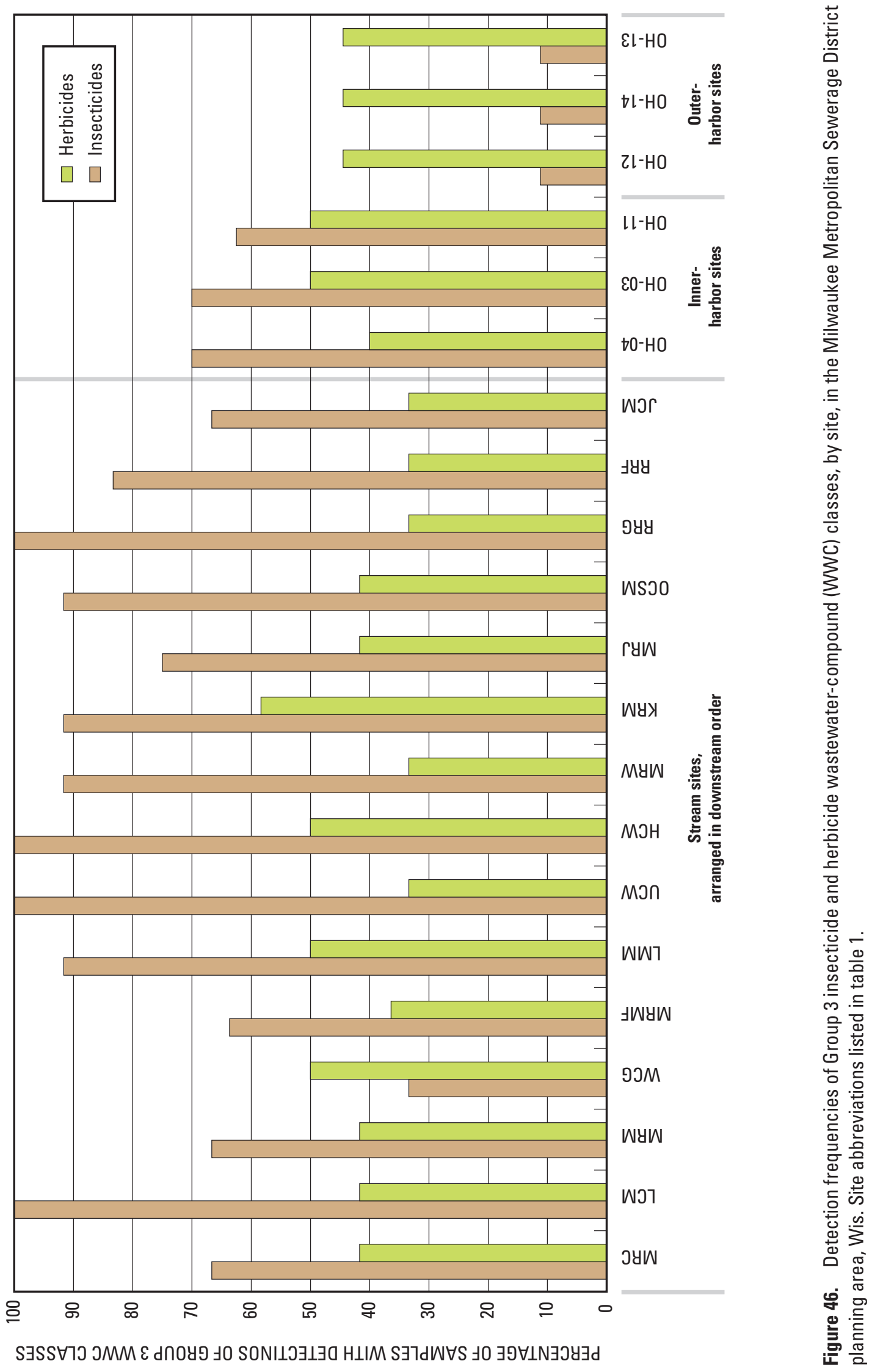




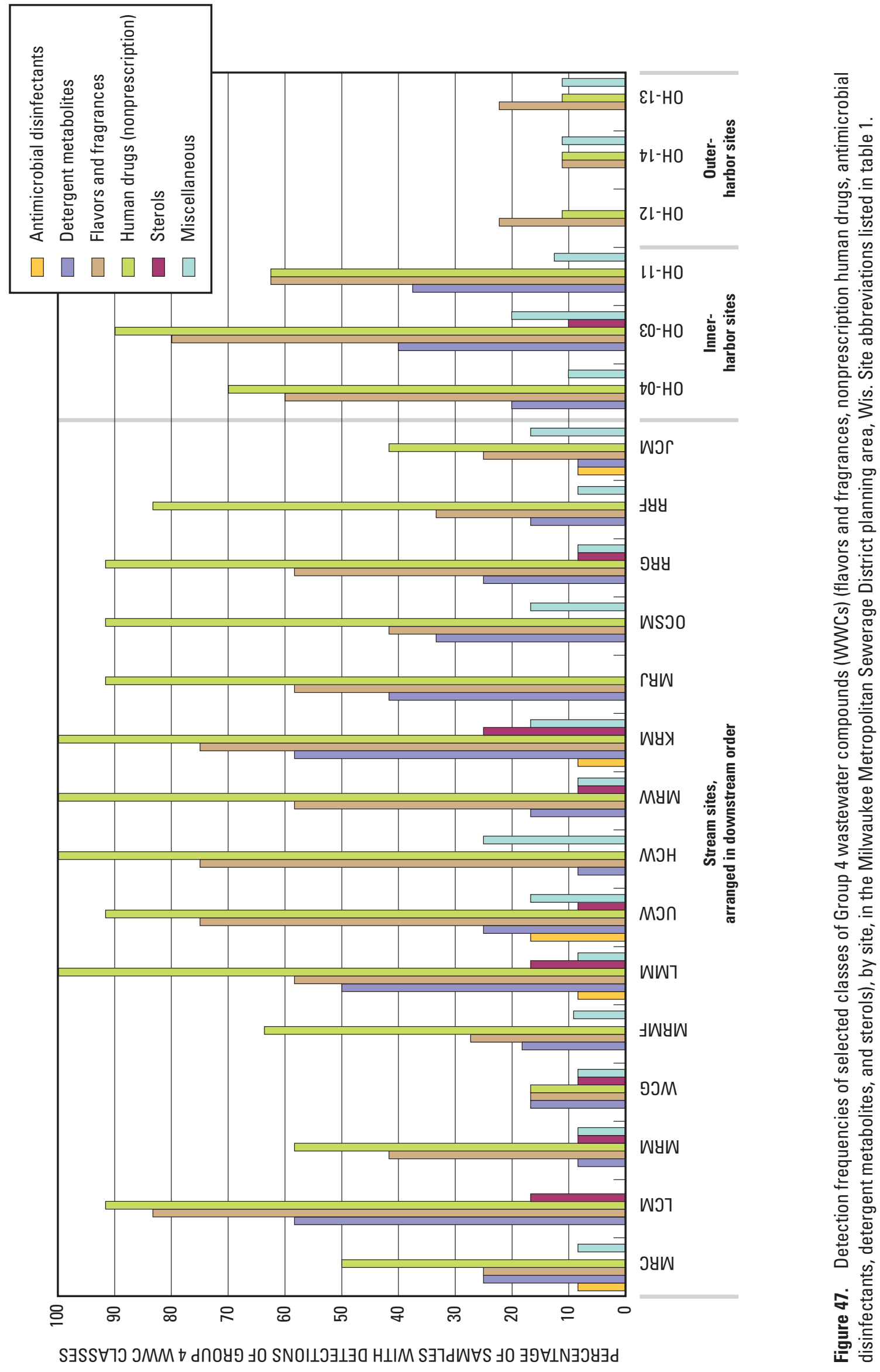




\section{Response to Flow and Seasonality}

At the stream sites, WWC classes did not show a consistent response with respect to flow alone (table 21 , fig. 48). A seasonal response was more apparent (fig. 49); when flow and seasonality was considered together (figs. 50 and 51, table 21), certain groups indicated more consistent responses. In the following discussions of the effects of combined flow and seasonality on stream samples, autumn samples were not discussed because there was a lack of high-flow-event samples collected during that season.

WWC classes from Group 1 indicated a variety of responses in DFs at stream sites with relation to flow, seasonality, and the combined effects of flow and seasonality. The antioxidant class had a higher DF during low-flow events than during high-flow events. The DF observed in winter samples was the highest of any season. When flows were combined with seasonality, the highest DF (29 percent) was observed during winter low-flow events while no detections occurred during winter high-flow events. The dyes and pigments class had a higher DF during high-flow events (77 percent) than during low-flow events (67 percent); however the difference was not very pronounced. No consistent seasonal response was observed, and no additional response was observed when flows were combined with seasonality. The fire-retardant class did not indicate consistent responses with respect to flow or season. PAHs indicated a moderate response with respect to flow, with samples collected during high-flow events having a higher DF than those collected during low-flow events (70 percent and 59 percent, respectively). Spring and winter had the highest DFs (both 77 percent) while autumn had the lowest (33 percent). No additional response was observed when flows were combined with seasonality. The plasticizer class indicated a moderate response with respect to flow, with samples collected during low-flow events (59 percent) having a higher DF than those collected during high-flow events (45 percent). Samples collected during autumn had the lowest DF (37 percent) while those collected in spring, summer, and winter all had approximately the same DFs (around 55 percent). No additional response was observed when flows were combined with seasonality.

WWC classes from Group 2 indicated a variety of responses in DFs at stream sites with relation to flow, seasonality, and the combined effects of flow and seasonality. The fuel class did not show a consistent response with respect to flow. The highest DFs of fuel occurred during winter (20 percent) and spring (15 percent). When flows were combined with seasonality, the highest DFs occurred during winter high-flow events (31 percent) and spring low-flow events (25 percent). The solvent class did not indicate a consistent response with respect to flow. Samples collected in the spring had the highest DF (23 percent) while those collected in autumn had no detections. When flows were combined with seasonality, samples collected during spring low-flow events had the highest DF (35 percent). WWC classes from Group 3 indicated a variety of responses in DFs at stream sites with relation to flow, seasonality, and the combined effects of flow and seasonality. The herbicide class did not demonstrate a consistent response with respect to flow. Spring and summer had the highest DFs of herbicides (68 and 54 percent, respectively) with no detections occurring during autumn and very few occurring during winter (DF of 3 percent). When flows were combined with seasonality, spring low-flow events had the highest DF ( 85 percent), followed by spring high-flow events (60 percent). All winter detections of herbicides occurred during high-flow events. Insecticides indicated no consistent response with respect to flow or season alone. However, when flows were combined with seasonality, winter low-flow events had the highest DF (100 percent). This observation was unexpected and was thought to be caused by contamination of samples by field vehicles or equipment.

WWC classes from Group 4 indicated a variety of responses in DFs at stream sites with relation to flow, seasonality, and the combined effects of flow and seasonality. The antimicrobial-disinfectant class had higher DFs during high-flow events than during low-flow events. With respect to seasonality, samples collected during winter had the highest DF (10 percent) of any season (fig. 49, table 21). The detergent metabolite class did not demonstrate a consistent response with respect to flow. With respect to seasonality, the highest DFs were observed in spring samples (38 percent). When flows were combined with seasonality, highest DFs were observed in spring and winter low-flow-event samples (50 and 43 percent, respectively). The flavors and fragrances class did not demonstrate a consistent response with respect to flow. With respect to seasonality, winter samples had the highest DF (80 percent) followed by spring (58 percent, DF); autumn had the lowest DF (23 percent). No additional response was observed when flows were combined with seasonality. The nonprescription-human-drug class did not indicate consistent responses with respect to flow or seasonality alone. When flows were combined with seasonality, winter high-flow events had the highest DF (94 percent). The sterol class did not indicate a consistent response with respect to flow. With respect to seasonality, the highest 


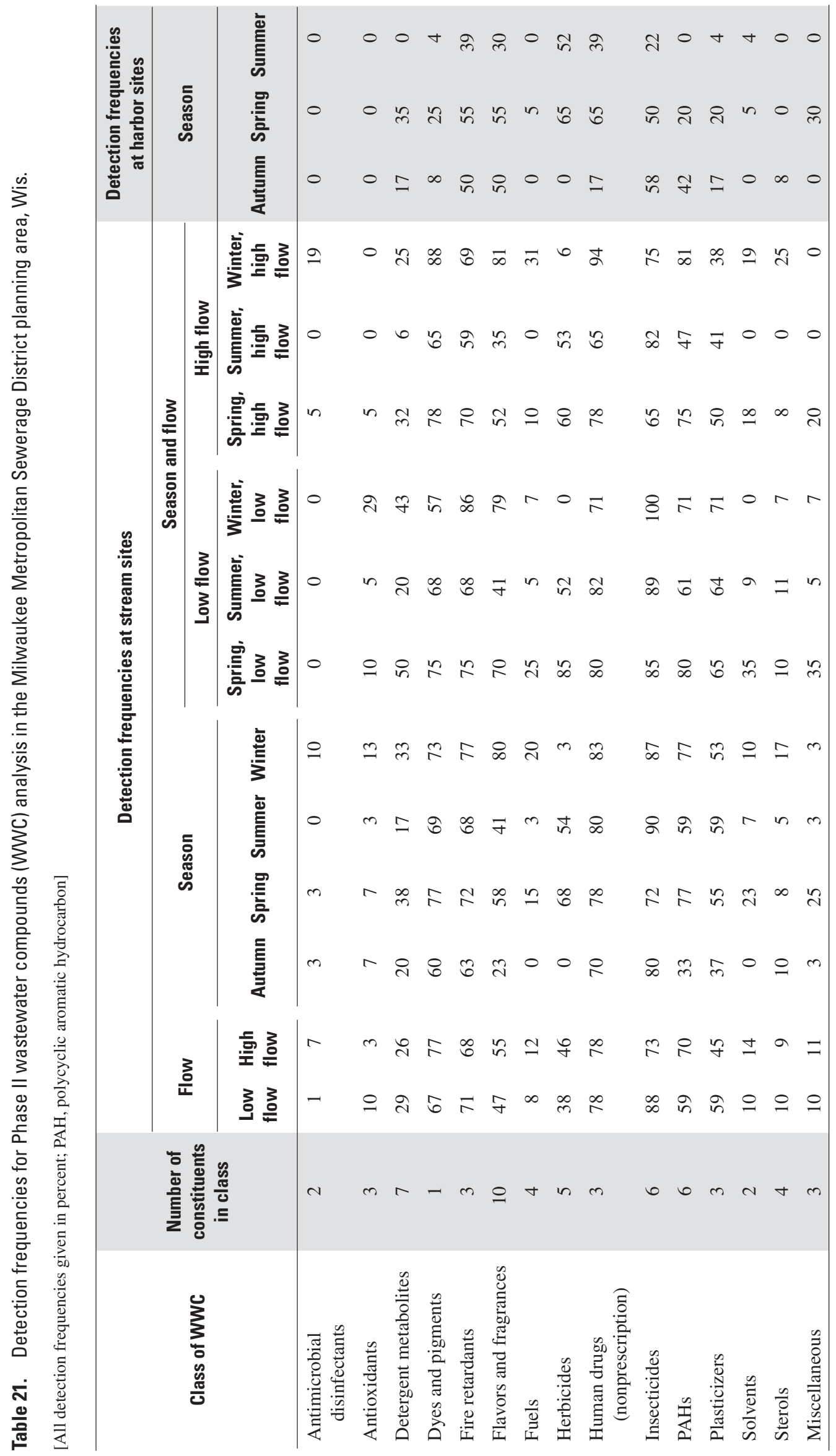


Wastewater-compound (WWC) detections at stream sites, by flow

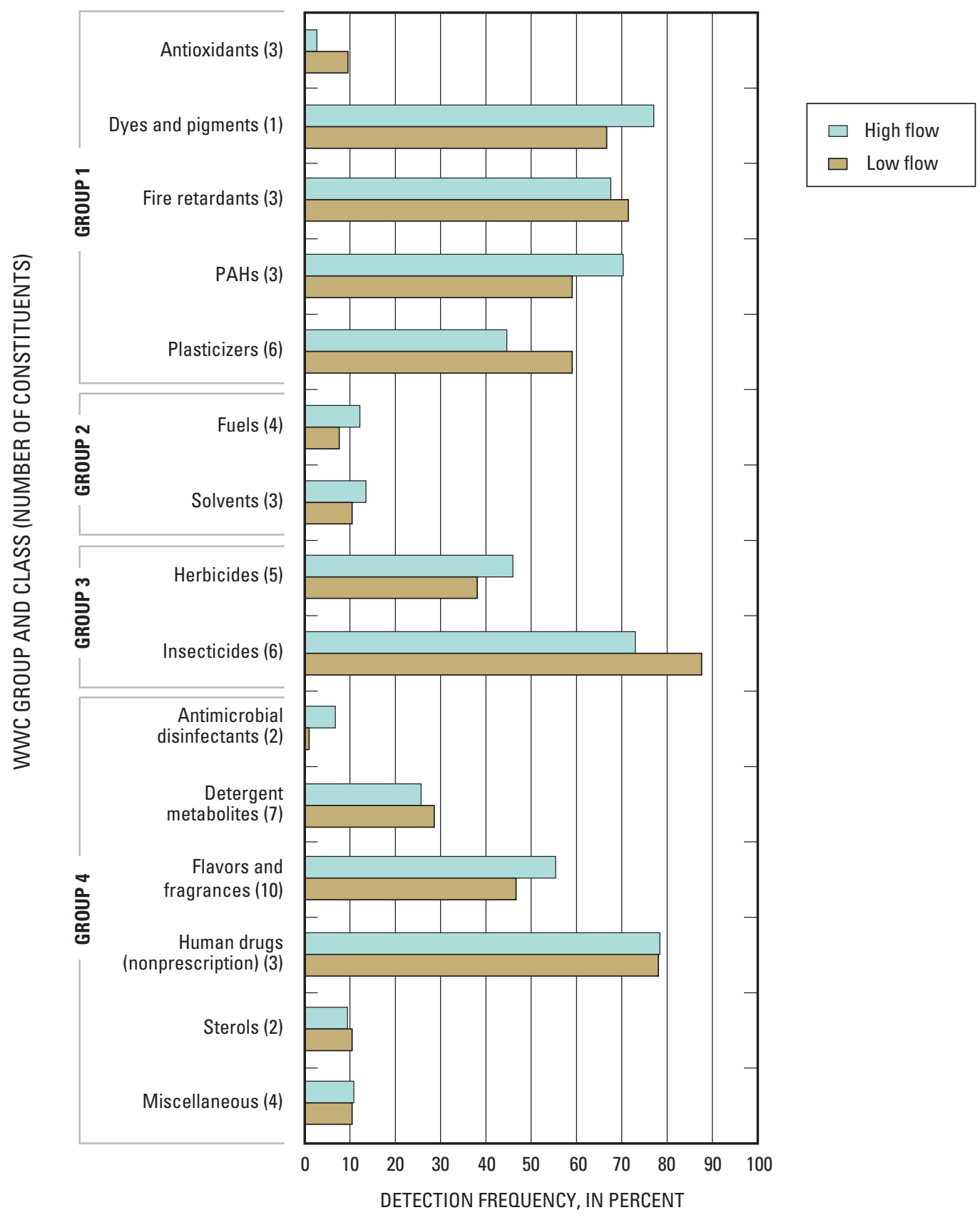

Figure 48. Detection frequency of stream samples with wastewater-compound (WWC) detections during high- and low-flow periods, by WWC class (and number of constituents), in the Milwaukee Metropolitan Sewerage District planning area, Wis. 
Wastewater-compound (WWC) detections at stream sites, by season

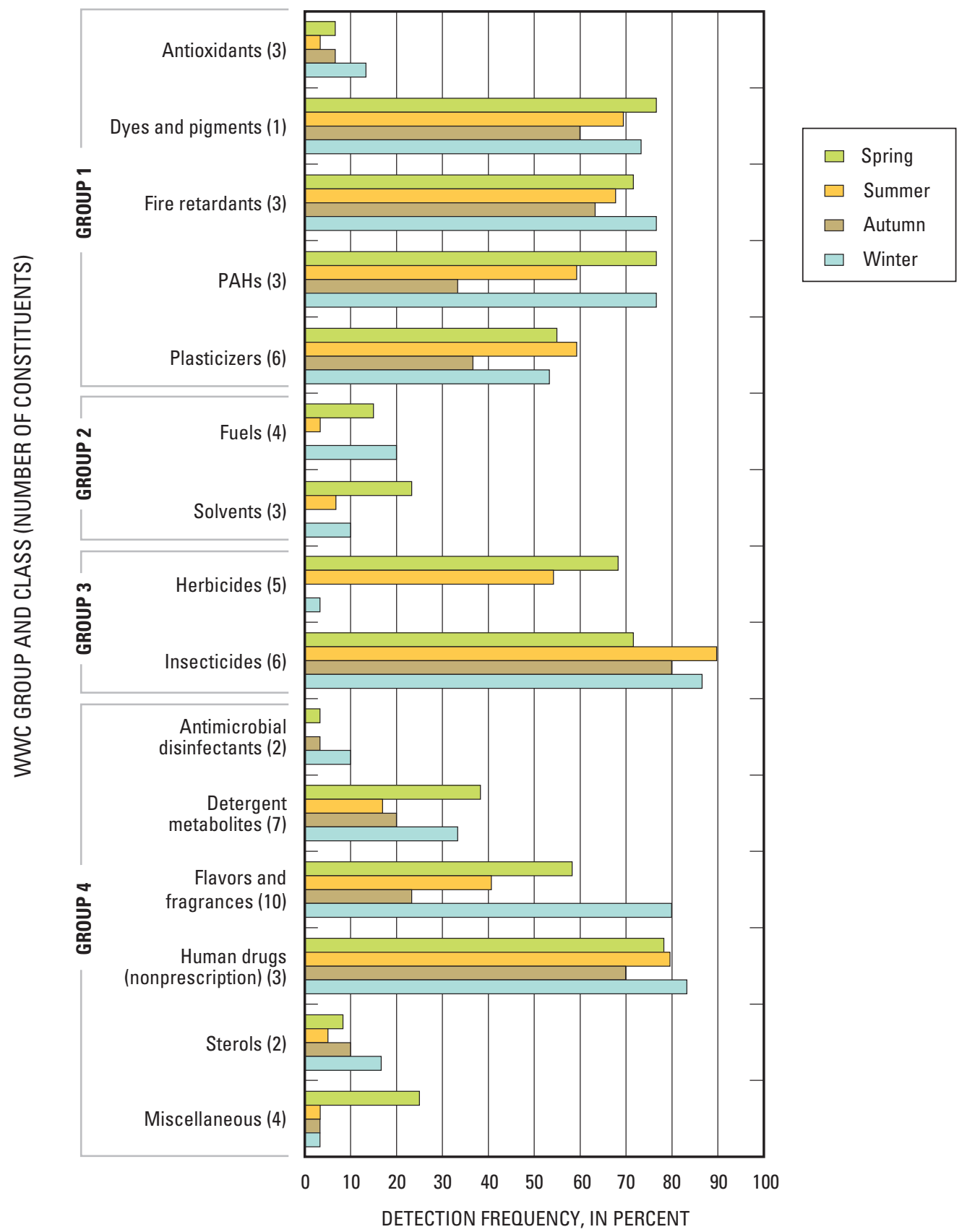

Figure 49. Detection frequency of stream samples with wastewater-compound (WWC) detections, by season and WWC class (and number of constituents), in the Milwaukee Metropolitan Sewerage District planning area, Wis. 
Wastewater-compound (WWC) detections at stream sites during low-flow periods, by season

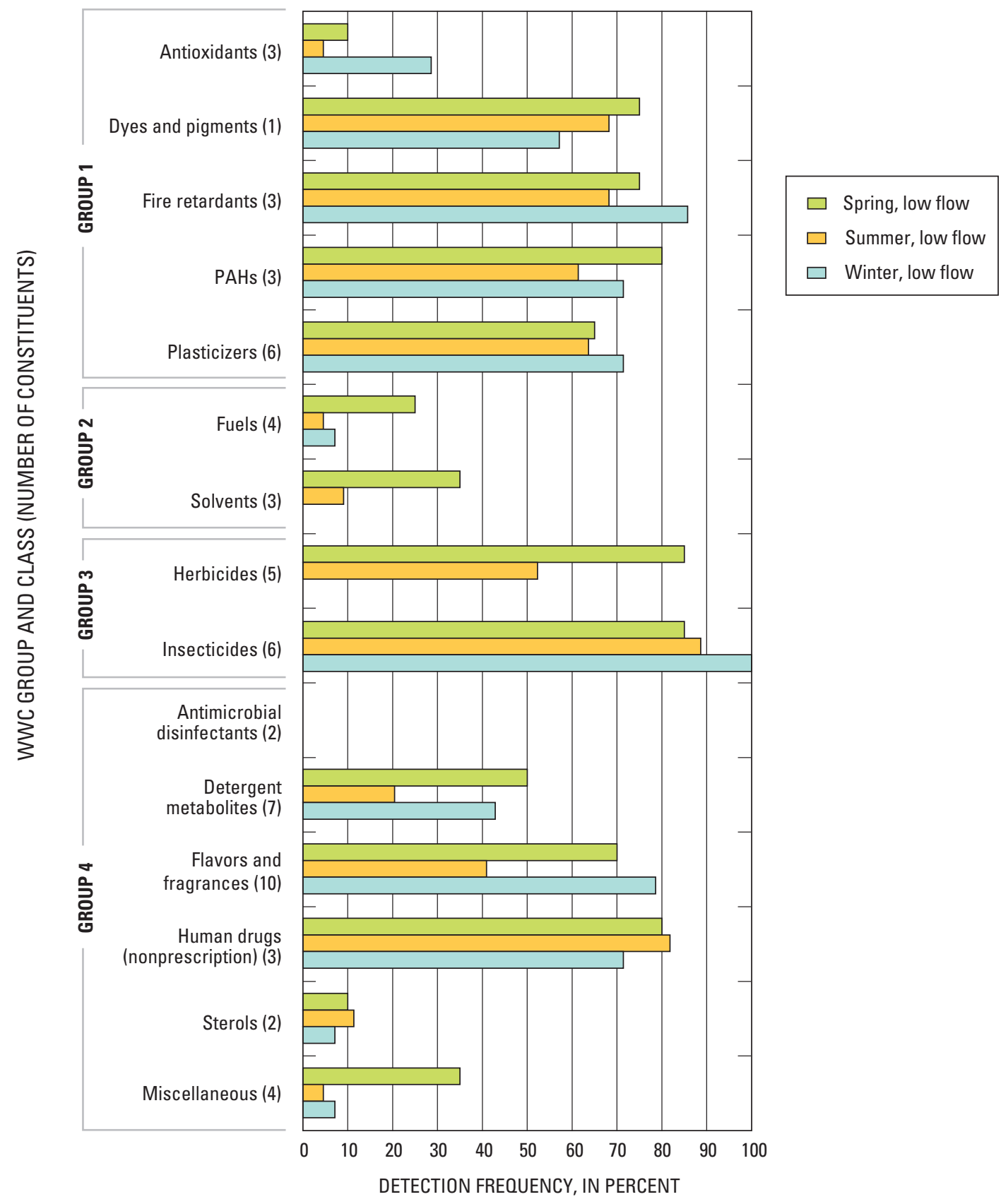

Figure 50. Detection frequency of stream samples with wastewater-compound (WWC) detections during low-flow periods, by season and WWC class (and number of constituents), in the Milwaukee Metropolitan Sewerage District planning area, Wis. 


\section{Wastewater-compound (WWC) detections at stream sites during high-flow periods, by season}

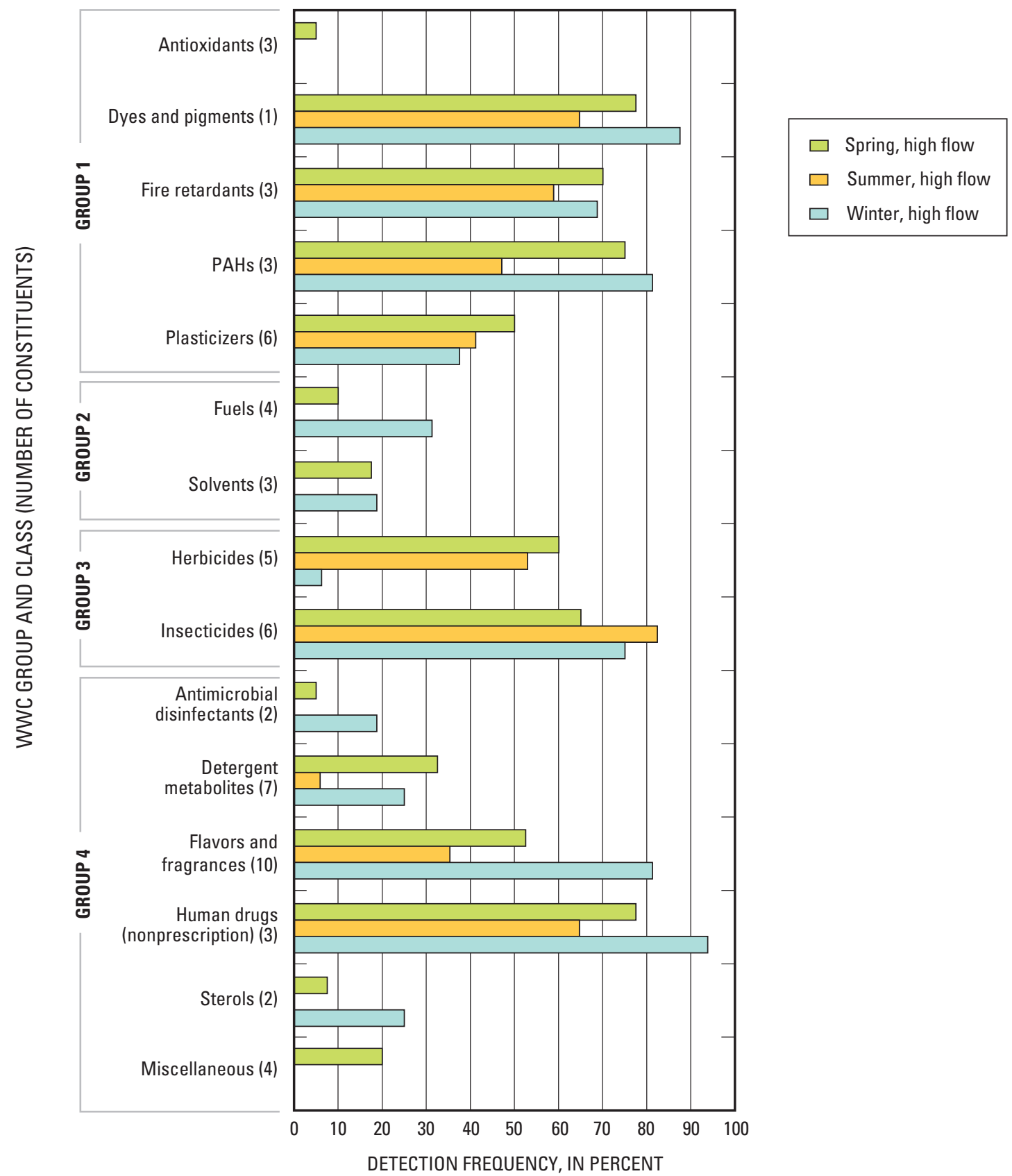

Figure 51. Detection frequency of stream samples with wastewater-compound (WWC) detections during high-flow periods, by season and WWC class (and number of constituents), in the Milwaukee Metropolitan Sewerage District planning area, Wis. 
DFs occurred in winter (17 percent) and autumn samples (10 percent). When flows were combined with seasonality, no consistent response was observed with respect to seasonality. However, a consistent response was observed in relation to flow. Winter high-flow events had the highest DF (25 percent), followed by spring high-flow events (DF of 8 percent); summer high-flow-event samples had no detections for sterols (fig. 48-51, table 21). The miscellaneous class did not demonstrate a consistent response with respect to flow. With respect to seasonality, spring samples had the highest detection frequency (25 percent). When flows were combined with seasonality, spring samples collected during low-flow and high-flow events had the highest DFs (35 percent and 20 percent, respectively); no detections were observed in high-flow-event samples collected during summer or winter.

Harbor samples could only be examined for seasonal responses. Two classes of WWCs were not detected in harbor samples: antimicrobial disinfectants and antioxidants (fig. 52, table 21). The herbicide and nonprescription-human-drug classes were detected with the greatest frequency in harbor samples, with spring samples showing the highest DF at 65 percent. More classes were detected and at higher frequencies in samples collected during spring. WWCs in the fuel and miscellaneous classes were detected only in spring samples. The solvent and herbicide classes were not detected in autumn samples. The PAH and detergent metabolite classes were detected only in spring and autumn samples. The sterol class was only detected during autumn sampling ( 8 percent) (fig. 52 , table 21).

\section{Dominant Constituents in Wastewater Compound Classes}

Within each class of WWCs, the data were analyzed to determine which, if any, constituent was driving detections and (or) responses for each class (table 20). DFs in stream samples were higher than those in harbor samples for every class of WWCs. Each of the classes comprising Group 1 was affected by the prevalence of detections of individual constituents within that class. Of the two constituents of the antimicrobial-disinfectant class, $p$-Cresol was the only constituent detected, with an overall DF of 3 percent; it was detected only in streams. It is commonly used as an industrial solvent, an insecticide, and it is an ingredient in common household cleaners and disinfectants (Agency for Toxic Substances and Disease Registry, 2006). Of the three constituents in the antioxidant class, only 5methyl-1H-benzotriazole was detected, with an overall DF of 5 percent. It is commonly used as an antioxidant in antifreeze and deicers, and has been identified as one of the constituents found in runoff from airport deicing activities (Corsi and others, 2003). Highest DFs for this constituent were observed at the Kinnickinnic River site during a winter sampling event. The dyes and pigments class was composed of only one constituent: 9,10-anthraquinone. It had an overall DF of 57 percent, and, although it was found in both stream and harbor samples, DFs were higher in stream samples than in harbor samples. Of the three constituents in the fire-retardant class, tris(2-butoxyethyl) phosphate was the most dominant. Although all three were detected in both stream and harbor samples, tris(2butoxyethyl) phosphate was detected most frequently, with an overall DF of 58 percent; tributyl phosphate and tris(dichloroisopropyl) phosphate both had overall DFs around 30 percent. Of the 6 constituents in the PAH class, 5 were detected in at least one sample. Fluoranthene had the highest overall DF (46 percent), followed by pyrene (37 percent) and phenanthrene (37 percent); the remaining constituents had DFs less than 30 percent in stream samples. All but one constituent in this class (anthracene) were detected in both stream and harbor samples; constituents in this class had lower DFs in harbor samples than in stream samples. Of the 3 constituents in the plasticizer class, all were detected in both stream and harbor samples, however tris(2-chloroethyl) phosphate was the dominant constituent, with an overall DF of 39 percent.

Each of the classes comprising Group 2 was affected by the prevalence of detections of individual constituents within that class. Of the 4 constituents in the fuel class, only 3 were detected in samples. The most dominant constituent was 2-Methylnaphthalene (DF of 8 percent). Both constituents in the solvent class were detected in stream and harbor samples; however, isophorone was dominant, with an overall DF of 7 percent. Isophorone is an industrial chemical used as a solvent in some printing inks, paints, lacquers, and adhesives. It is also used as an intermediate in the production of certain chemicals (Agency for Toxic Substances and Disease Registry, 1999). Tetrachloroethlyene had an overall DF of 3 percent.

Each of the classes comprising Group 3 was affected by the prevalence of detections for individual constituents within that class. Of the 5 constituents in the herbicide class, only 4 were detected in samples. Metolachlor is a pre-emergent herbicide and is commonly used to control certain broadleaf and annual grassy weeds on agricultural land and on highway rights-of-way (Oregon State University, 1996); it had the highest overall DF (39 percent), and was the WWC with the highest DF in harbor 
Wastewater-compound (WWC) detections at harbor sites, by season

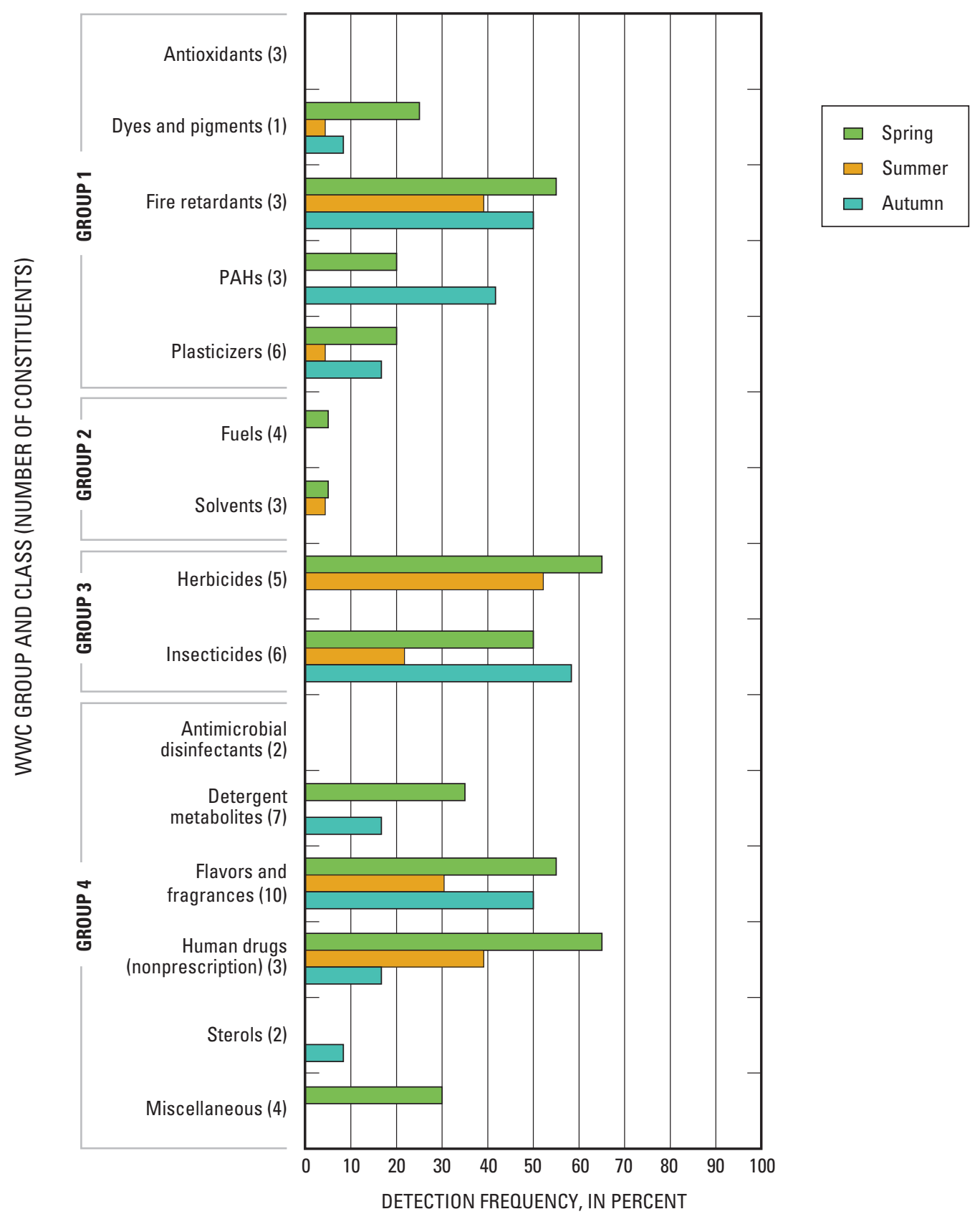

Figure 52. Detection frequency of harbor samples with wastewater-compound (WWC) detections, by season and WWC class (and number of constituents), in the Milwaukee Metropolitan Sewerage District planning area, Wis. (No harbor samples were collected in winter.) 
samples. Prometon is a non-selective herbicide and is commonly used for total vegetation control on industrial sites, for noncrop areas on farms, and around and under asphalt (Capel and others, 1999); it had a slightly lower overall DF (31 percent) than metolachlor. Both of these herbicides were detected in stream and harbor samples. The remaining two constituents detected (bromacil and pentachlorophenol) were detected at low frequencies in stream samples and were not detected in harbor samples. Of the six constituents in the insecticide class, DEET (the most common active ingredient in insect repellents) had the highest overall DF, at 64 percent (U.S. Environmental Protection Agency, 2005b). Carbazole was the secondmost-frequently detected insecticide (overall DF of 29 percent), followed by carbaryl (overall DF of 18 percent), and diazinon (overall DF of 15 percent). Chlorpyrifos had a very low overall DF (1 percent) and was found only in harbor samples, whereas dichlorvos was detected only in stream samples, at an overall DF of less than 1 percent.

Each of the classes comprising Group 4 was affected by the prevalence of detections of individual constituents within that class. Of the 7 constituents in the detergent metabolite class, only 3 were detected in samples: diethoxynonylphenol (overall DF of 18 percent) was the most dominant constituent, followed by 4-nonylphenol (overall DF of 9 percent), and ethoxyoctylphenol (overall DF of 1 percent). Of the 10 constituents in the flavor/fragrance class, only 8 were detected in samples, the most dominant constituent being acetophenone (overall DF about 30 percent). Of the three constituents in the nonprescription-human-drug class, caffeine was the most dominant. Although all three constituents were detected in both stream and harbor samples, caffeine was the most frequently detected (overall DF of 63 percent). The remaining two constituents of this class (menthol and cotinine) were detected less frequently (26 and 35 percent overall DF, respectively). Of the four constituents in the sterol class, cholesterol was the dominant constituent, with an overall DF of 5 percent. Cholesterol is often considered as a fecal indicator, but it is also a plant sterol. All four constituents in the sterol class were detected in stream samples, but cholesterol was the only sterol detected in harbor samples. Of the 3 constituents in the miscellaneous WWC class, 1,4-dichlorobenzene was the dominant constituent, with an overall DF of 7 percent; the remaining 2 constituents had DFs of 1 and 3 percent.

\section{Endocrine-Disrupting Chemicals}

Of the 62 WWCs, 20 are known or suspected endocrine disrupting chemicals (EDCs) (table 20, constituents in bold). Of these 20,12 were detected and 8 were not detected. The dominant EDC constituent in all samples was tris(2-chloroethyl) phosphate (DF of 39 percent), followed by tris(dichloroisopropyl) phosphate (DF of 30 percent), diethoxynonylphenol (DF of 18 percent) and carbaryl (18 percent). Of the 234 samples collected, 149 had detections of at least one EDC (DF of 64 percent). The number of individual EDCs detected per sample ranged from zero to eight.

Among 179 stream samples, 126 had at least one EDC detected (DF of 70 percent). At stream sites, the number of individual EDCs detected per sample ranged from 0 to 8 , with a median of 2 EDCs detected per sample. Among 55 harbor samples, 23 had at least one EDC detected (DF of 42 percent). The number of individual EDCs detected per harbor sample ranged from 0 to 6 (table $15)$.

The distribution and frequency of individual EDCs detected in a sample are shown in figure 53. The frequency of individual EDC constituents detected and the number of samples with EDC detections suggested that several different EDCs were present and there was a consistent source of EDCs. Sites which had EDC detections in 10 or more samples and more than 30 individual EDCs detected included Lincoln Creek, Honey Creek and Little Menomonee River. Other sites that had EDC detections in 10 or more samples included Root River at Grange Avenue (10 of 12 samples) and Milwaukee River at Mouth (10 of 12 samples). One other site had more than 30 individual EDCs detected: Kinnickinnic River, with 36 individual EDCs detected.

In stream samples, there were no consistent patterns between EDC detections and flow, season, or flow and season combined. Harbor samples indicated some seasonal variability; summer samples had detection frequencies around 25 percent while spring and autumn samples had detection frequencies around 50 percent. 


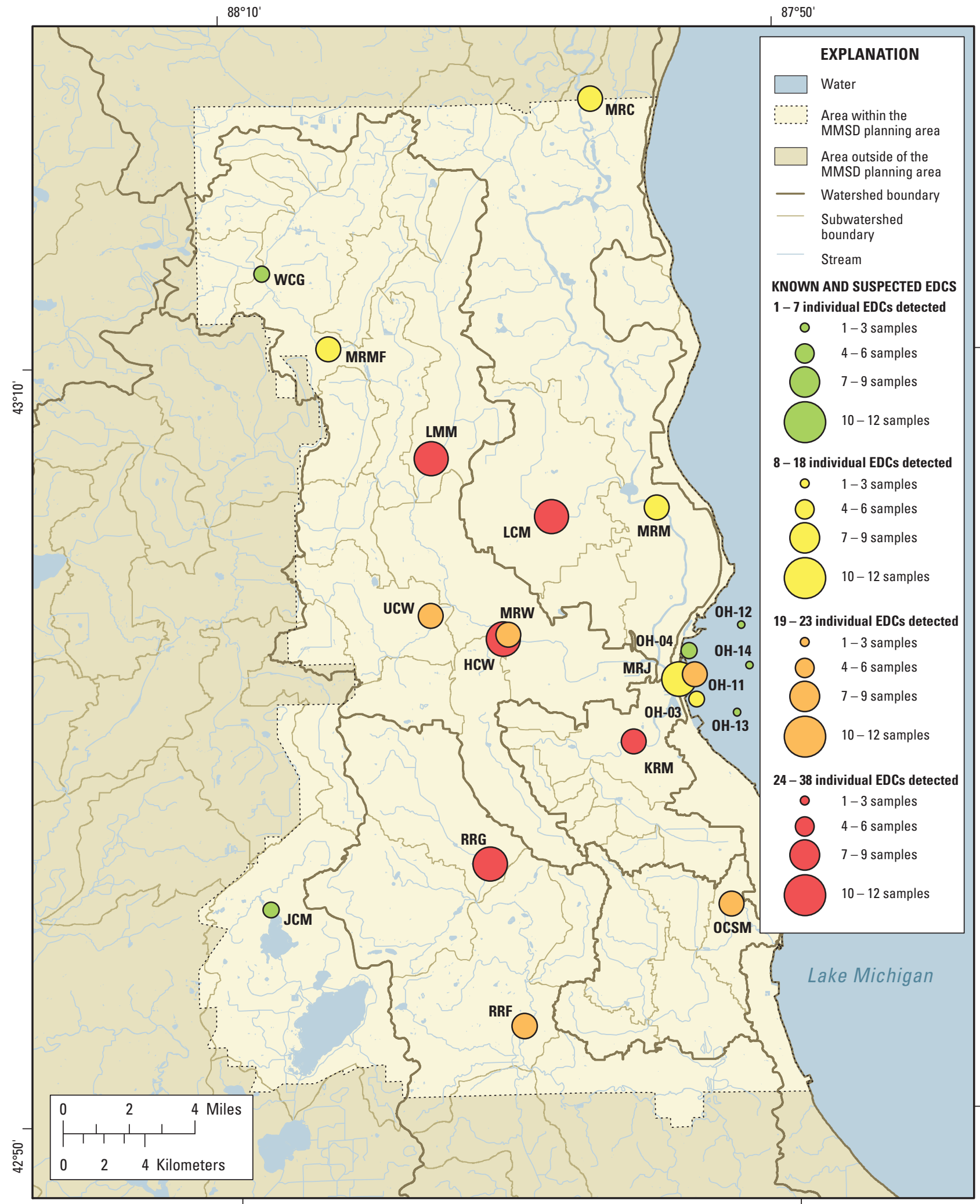

Base composited from Southeastern Wisconsin Regional Planning Commission regional base map, 1:2,000, 1995; U.S. Geological Survey digital line graph hydrography, 1:100,000, 1989; Wisconsin Department of Natural Resources version 2 hydrography, 1:24,000, 2002. Wisconsin Transverse Mercator Projection, referenced to North American Datum of 1983, 1991 adjustment.

Figure 53. Distribution and frequency of known and suspected endocrine-disrupting compounds (EDCs) in the Milwaukee Metropolitan Sewerage District (MMSD) planning area, Wis. Color describes the number of individual EDC constituents detected (by quartiles); size of symbol describes the number of sampling events when EDCs were detected. Site abbreviations listed in table 1. 


\section{Semipermeable Membrane Devices and Wastewater Compounds}

Analytical results from extracts of semipermeable membrane devices (SPMDs) from Milwaukee-area streams included evidence of potential toxicity to macroinvertebrates and fish due to synthetic organic compounds in water (table 22). WWC results can be compared with toxicity results by individual WWC constituent as well as by WWC class. In general, the same constituents at the same sites appeared in both SPMD results and WWC results; WWC results indicated where the constituents were occurring at high frequencies, whereas SPMD results indicated that these constituents had the potential to accumulate in fish tissue. For the remaining eight sites that were not sampled for SPMDs, the WWC data could indicate which sites would be of interest for further toxicity testing in Phase III.

Cytochrome P450RGS tests indicated potential toxicity from the presence of compounds like dioxins, PCBs, and PAHs in streamwater at all seven sites, with the highest potential toxicity at the Little Menomonee River, Root River at Grange Avenue, Oak Creek, Lincoln Creek, and Honey Creek sites (SPMD data for the Root River at Grange Avenue, Honey Creek, and Underwood Creek Phase II sites actually were sampled at nearby USGS NAWQA sites; see page 14 for more details).

Fluoroscan results indicated the presence of PAHs at all seven sites. The highest concentrations of PAHs found during 2004 were at Little Menomonee River and Menomonee River at Menomonee Falls. The concentration for Little Menomonee River was nearly twice that for Menomonee River at Menomonee Falls; concentrations for Root River at Grange Avenue, Honey Creek, Lincoln Creek, and Oak Creek were also high compared to other sampled sites. In addition to other sources, high concentrations of PAHs have been found in coal-tar-based sealcoats used on parking lots that break down over time and allow PAHs to be washed into waterways with runoff (Mahler and others, 2005).

Microtox tests indicated higher potential toxicity at the Underwood Creek site than at all other sampled sites in the Milwaukee area, suggesting that compounds other than those detected in the P450RGS or Fluoroscan tests were causing toxicity to the bioluminescent bacteria used in the Microtox test. Phase II results were examined for potential sources of this toxicity. Of the WWCs, 9,10-anthraquinone, and tris(2-butoxyethyl) phosphate had high DFs at Underwood Creek, and elevated concentrations of lead were found in bed sediments at this same site.
Chemical analyses of the SPMD extracts found the presence of several PAHs. The PAH phenanthrene was highest at the Menomonee River at Menomonee Falls site (750 ng/SPMD), but was also relatively high at the Root River at Grange Avenue (590 ng/SPMD), Honey Creek (380 ng/SPMD), and Little Menomonee River (340 ng/ SPMD) sites; SPMD results for anthracene, another PAH, indicated its presence in these four streams as well. Phase II results from WWC data analysis in water indicated that phenanthrene was present at all the same sites at a DF of 50 percent or greater. The site with the highest detections of phenanthrene was Underwood Creek (100 percent), followed by Root River at Grange Avenue (77 percent) and Little Menomonee River (75 percent). WWC water analysis indicated anthracene was present at low DFs (33 percent or less) in 5 of the 7 sites, and absent at Menomonee River at Menomonee Falls and Oak Creek.

SPMD results for pyrene and fluoranthene had the highest concentrations at the Little Menomonee River (1,700 and 1,640 ng/SPMD, respectively), Root River at Grange Avenue (2,100 and 1,600 ng/SPMD, respectively), and Menomonee River at Menomonee Falls (1,900 and 1,300 ng/SPMD, respectively) sites. Naphthalene was found only in the SPMD results for Little Menomonee River, whereas methylnaphthalene compounds were found at Little Menomonee River and Root River at Grange Avenue. WWC results for pyrene indicated the highest DFs at Underwood Creek (100 percent), Little Menomonee River (83 percent), Root River at Grange Avenue (77 percent) and Honey Creek (75 percent). WWC results also indicated 100-percent DFs for fluoranthene at Little Menomonee River, Underwood Creek, and Root River at Grange Avenue. WWC DFs for naphthalene were relatively low at all sites (33 percent or less), even though it was detected at 5 of the 6 sites; DFs for 1- and 2-methylnaphthalene were even lower than those for naphthalene (25 percent or less).

Overall, results for toxicity tests (performed on SPMD extracts) and individual constituent analyses (performed on both SPMD extracts and water) from Little Menomonee River had moderate to high concentrations and DFs, and indicate that PAHs may be an issue of particular concern at this site. Contamination at this site may be attributed to the Moss-American Superfund site located upstream.

In summary, the combination of WWC results, in concert with toxicity tests and chemical analyses based on SPMD results, confirmed that concentrations of some synthetic organic compounds were of concern to aquatic biota in MMSD-area streams. 


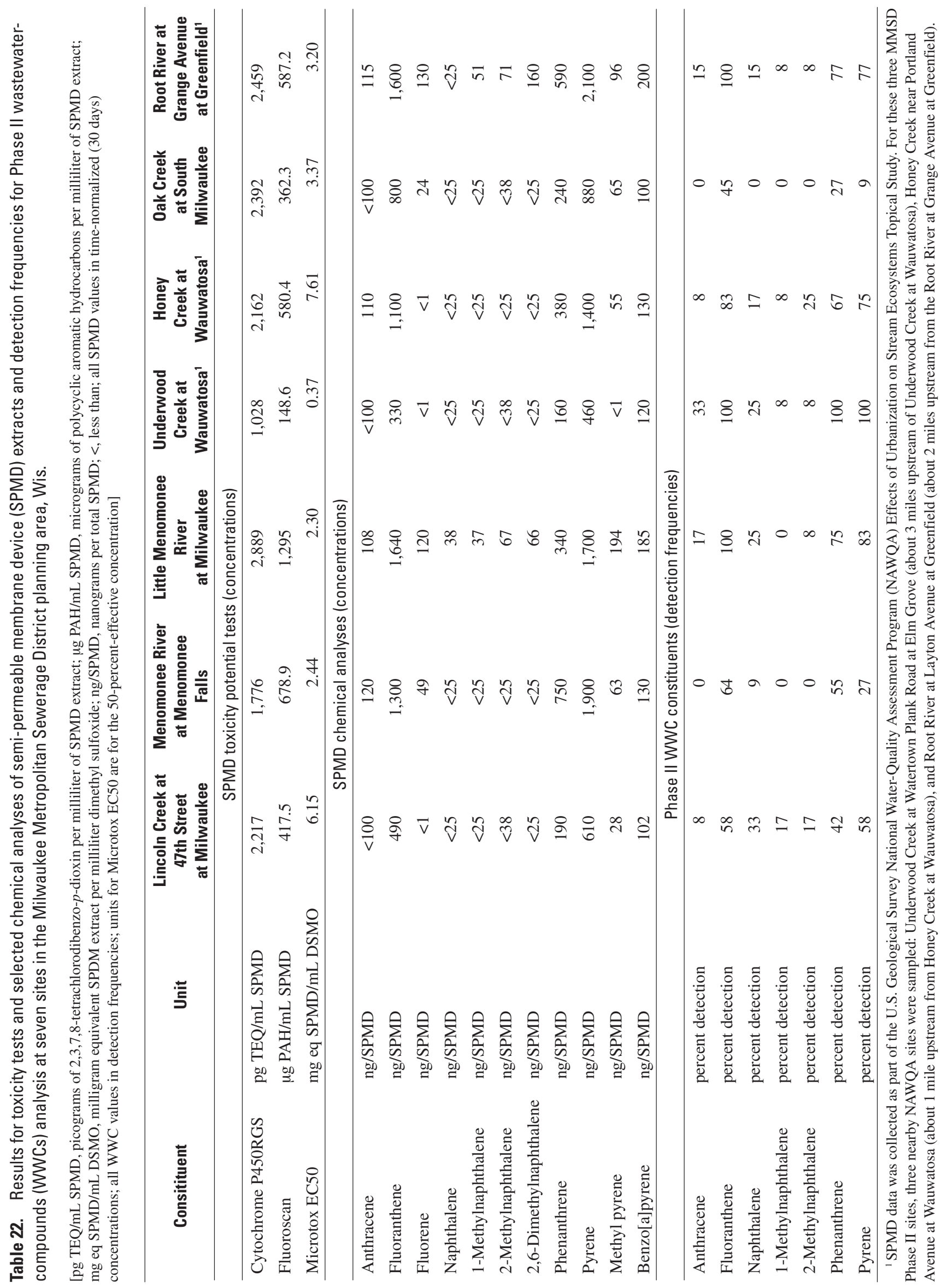




\section{Bed Sediment}

Bed-sediment analyses are an effective means of integrating contamination episodes in stream segments over extended time periods since many metals and organic chemicals sorb onto fine sediment particles. Sediment traps were used collect sediment for the assessment of transport rates of trace metals and PCBs at all stream sites.

\section{Physical Characteristics of Sediment-Trap Contents}

Sediment traps were deployed at each of the 15 stream-sampling locations. The mass of sediment recovered from traps deployed at the 15 stream sites is depicted in figure 54 (left panel). Particle sizes can be described as a percentage of sand, silt, and clay (right panel). Samples from traps that yielded the greatest mass of recovered sediments were composed primarily of sand.
Traps deployed in 2005 collected a higher fraction of silt- and clay-size particles and a correspondingly lower fraction of sand-size particles compared to traps deployed in 2004. The differences seen in the particle-size distributions between the 2004 and 2005 field seasons were likely related to differences in rainfall, stream discharge, and the time period chosen for trap deployment. Area streams in 2004 had higher flows than in 2005, and may be the reason for the higher fraction of coarse-grained sediments in traps.

Sediment samplers deployed as part of Phase II were not designed to provide quantitative estimates of sediment transport. Nevertheless, the results shown in figure 55 provide information on the approximate particle-size classes that were transported as suspended sediment. Because of the design of the samplers, the smallest particle-size classes (clay size and smaller) probably were underestimated because the sediment-trap efficiency for those size classes is thought to be quite low.

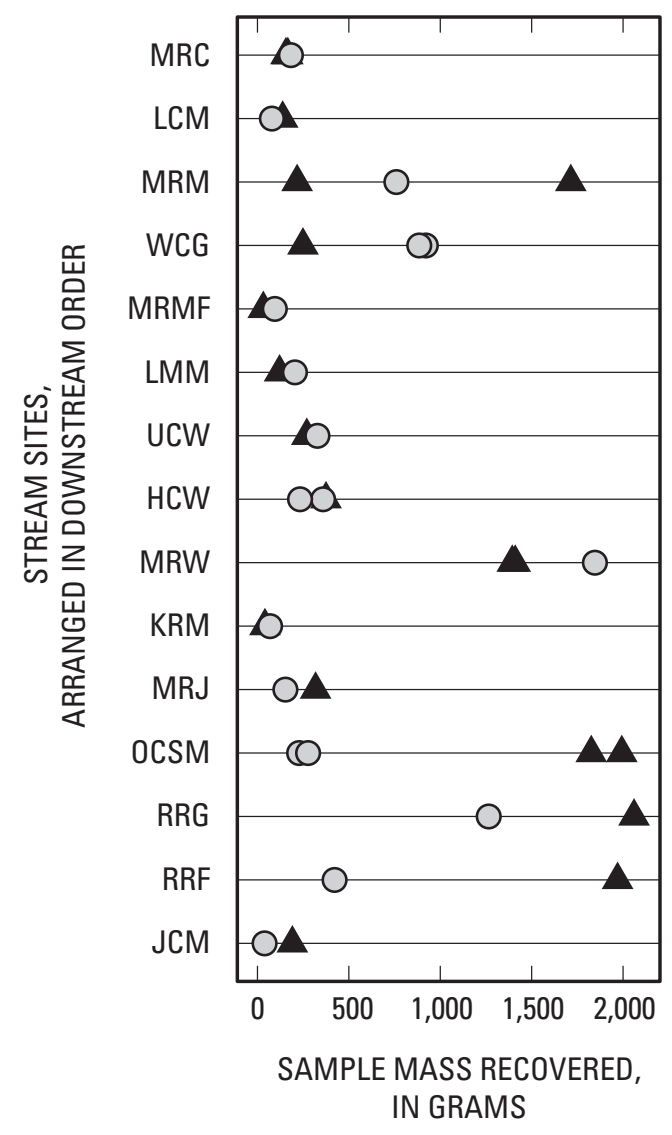

\section{EXPLANATION}
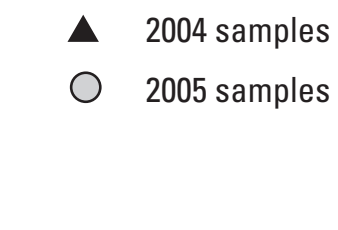

Figure 54. Mass and particle-size distribution of sediment captured in Phase II sediment traps in the Milwaukee Metropolitan Sewerage District planning area, Wis. Site abbreviations listed in table 1. 


\section{Comparison of Sites by Use of Average Effect Concentrations}

The material collected in the sediment traps was analyzed for arsenic, cadmium, chromium, copper, lead, mercury, nickel, zinc, total phosphorus, and total PCBs. In some cases, not enough material was collected to allow all analyses to be run. The sediment-trap results were summarized by looking at specific chemicals alone and by combining the potential effects of all chemicals detected.

Results from two different methods of describing the significance of all chemicals detected in the sediment-trap samples are shown in figure 56. The left panel shows the total number of constituents that exceed the consensus- based threshold effect concentration (TEC) as listed in MacDonald and others (2000). The TEC is a conservative indicator of possible problems related to sediment chemistry; exceedence of even several TECs does not necessarily indicate toxicity. The right panel shows each sampling result divided by a consensus-based probable effects concentration (PEC), which yields a "PEC quotient." The PEC quotient was developed to relate bulk sediment-chemistry results to toxicity-test results involving experiments with benthic organisms (MacDonald and others, 2000). A mean PEC quotient can be computed from all individual PEC quotients for each sample.

\section{EXPLANATION}

Stream sites, arranged in downstream order
MRC
LCM
MRM
WCG
MRMF
LMM
UCW
$\bigcirc \mathrm{HCW}$
MRW
KRM
$\bigcirc \mathrm{MRJ}$
OCSM
RRG
RRF
$\bigcirc$ JCM

10

Sand

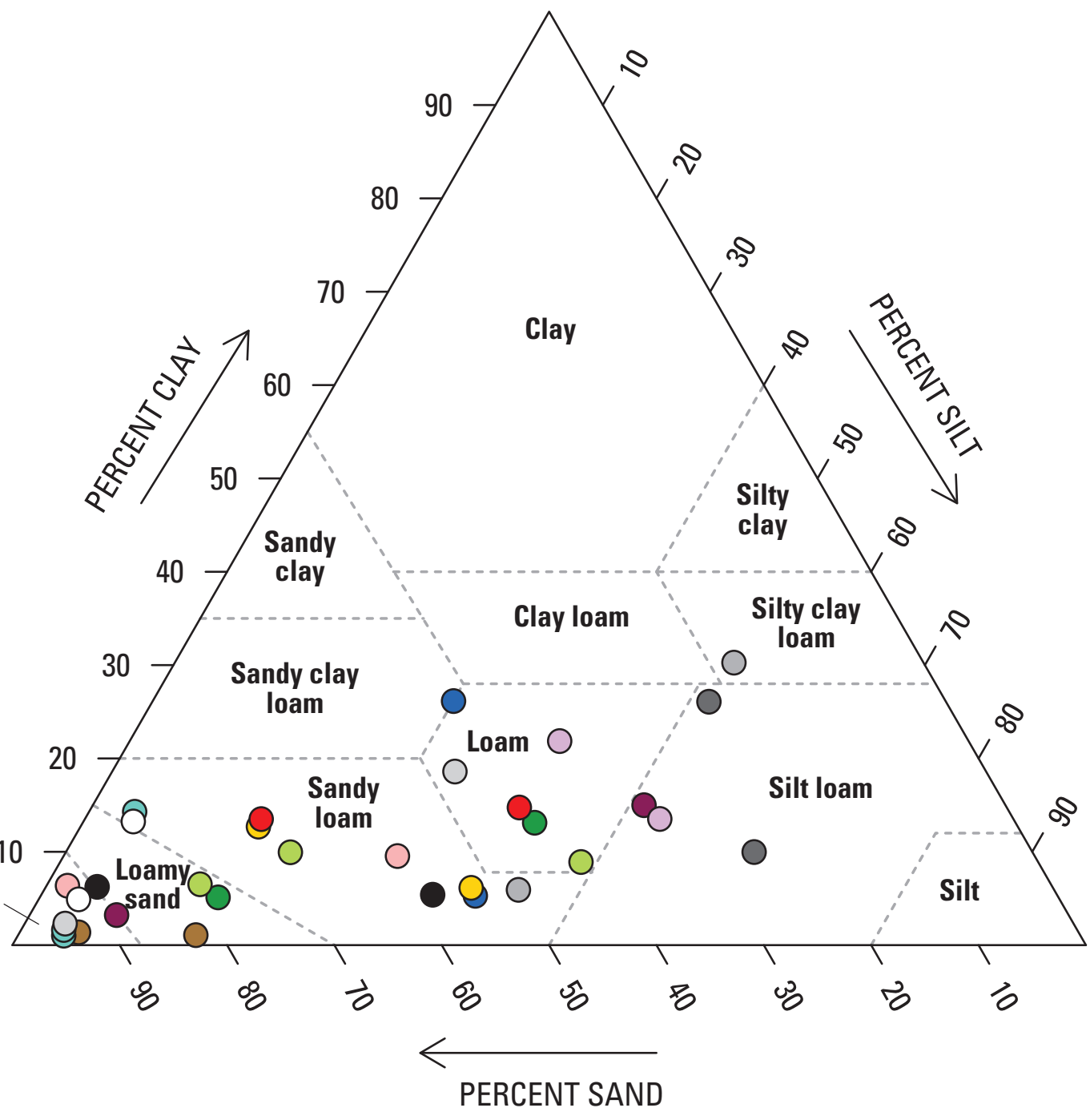

Figure 55. Particle-size distribution in sediment-trap samples, by Phase II sampling location, in the Milwaukee Metropolitan Sewerage District planning area, Wis. Site abbreviations listed in table 1. 
The developers of the PEC quotient noted that a PEC quotient that exceeds 0.5 is associated with increased toxicity in test organisms, and a PEC quotient between 1 and 5 is associated with a test-organism mortality rate exceeding 50 percent (MacDonald and others, 2000). Milwaukee River at Mouth was the only site where the mean PEC quotient exceeded 0.5 , suggesting the possibility of increased sediment toxicity.

The PEC quotients presented here did not account for effects of PAHs or chlorinated pesticide compounds, since these constituents were not analyzed for in conjunction with Phase II sampling efforts. Both of these classes of compounds could potentially change the mean PEC quotients relative to those presented above.

\section{Comparison of Sites by Use of Individual Contaminant Effects Concentrations}

The PEC quotients for individual contaminants at each sample site are summarized in figure 57. For certain sites, the mean PEC quotient differed greatly from PEC quotients calculated for individual contaminants. For example, Kinnickinnic River had the highest individual PEC quotient for copper, zinc, or mercury. Milwaukee River at Milwaukee and Milwaukee River near Cedarburg had high individual PEC quotients for total PCBs. Underwood Creek and Menomonee River at Wauwatosa had high individual PEC quotients for lead. By contrast, when the overall mean PEC quotient was considered, the Milwaukee River at Mouth site had the highest result, reflecting the additive effects of contaminants transported throughout the watershed.
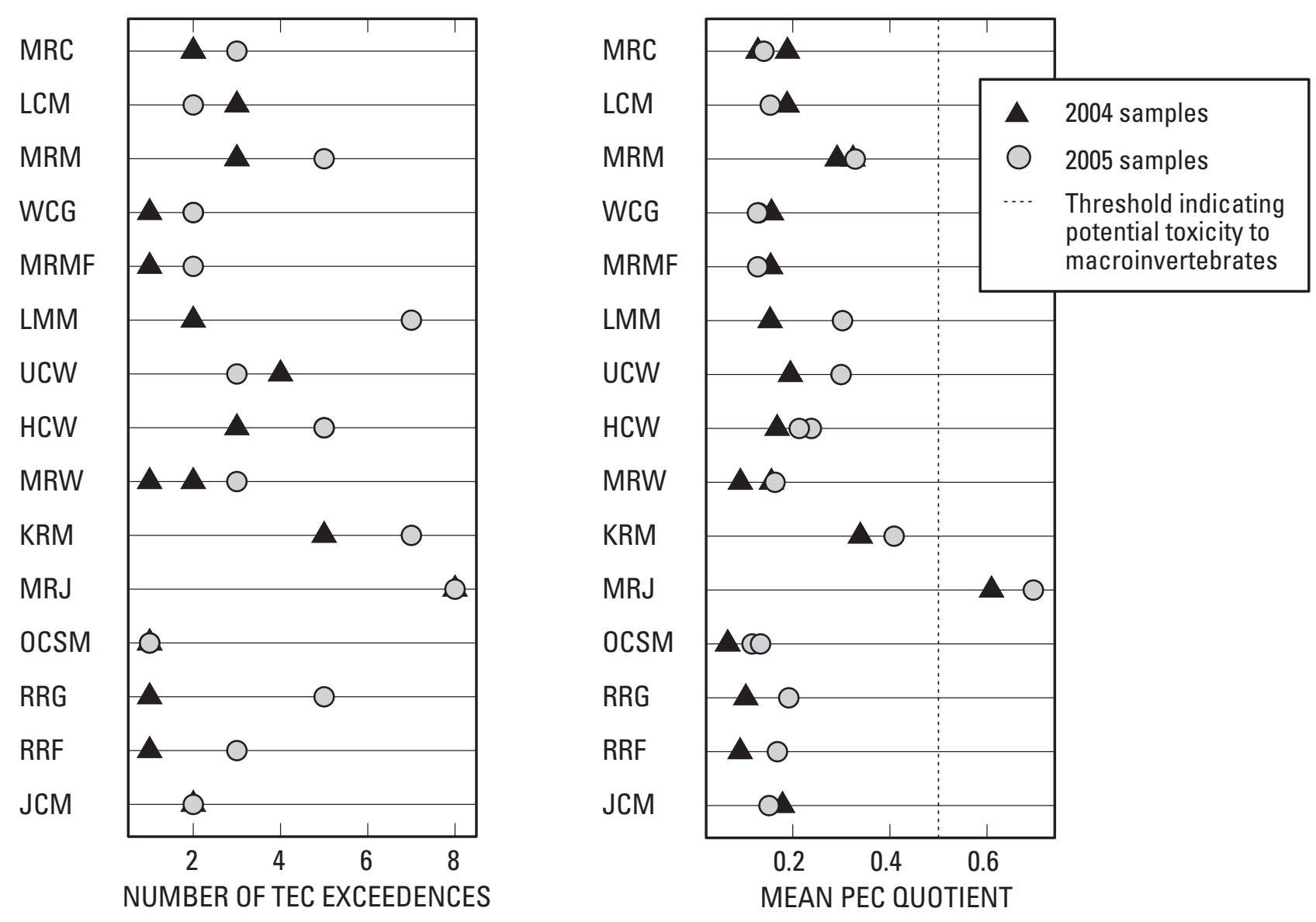

Figure 56. Number of consensus-based threshold effect concentration (TEC) exceedences and the mean consensus-based probable effects concentration (PEC) quotients for contaminants in sediments from the Milwaukee Metropolitan Sewerage District planning area, Wis. (MacDonald and others, 2000). Site abbreviations listed in table 1. 


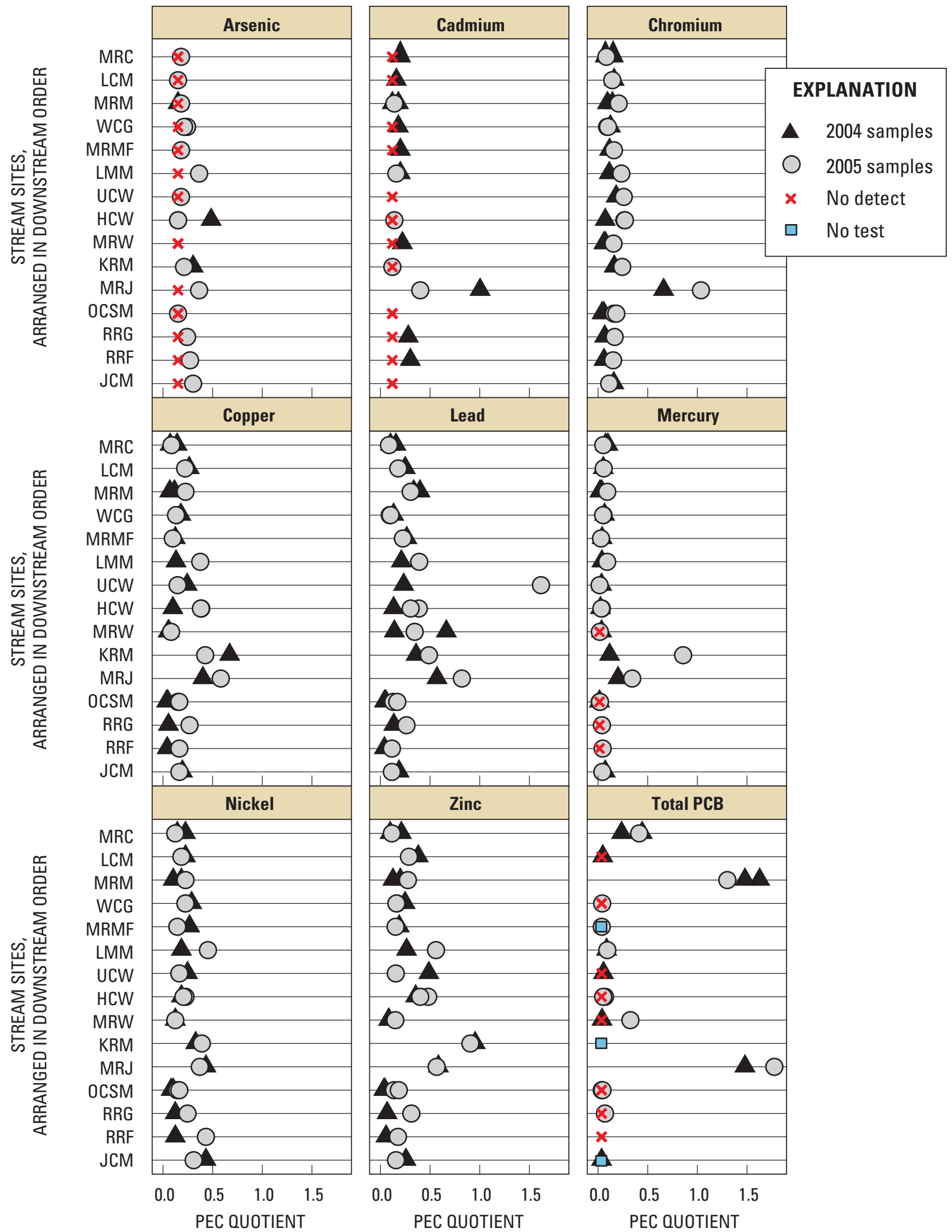

Figure 57. Consensus-based probable effects concentration (PEC) quotients for nine contaminants in the Milwaukee Metropolitan Sewerage District planning area, Wis. (MacDonald and others, 2000). Site abbreviations listed in table 1. 
Total PCBs were detected at almost all sites, and most of the detections were at concentrations near the level of detection (LOD). It was useful to compare the results for maximum total PCB concentrations to the TEC of 0.060 $\mathrm{mg} / \mathrm{kg}$, as defined by MacDonald and others (2000). Sediments with contaminant concentrations below the TEC generally do not cause toxicity. Samples from five of the sites met or exceeded the TEC for PCBs: Milwaukee River at Mouth $(1.2 \mathrm{mg} / \mathrm{kg})$, Milwaukee River at Milwaukee (1.1 $\mathrm{mg} / \mathrm{kg})$, Milwaukee River near Cedarburg (0.3 mg/kg), Menomonee River at Wauwatosa $(0.22 \mathrm{mg} / \mathrm{kg})$, and Little Menomonee River $(0.063 \mathrm{mg} / \mathrm{kg})$ (table 23). Results for all other sites fell below the TEC. The main stems of the Milwaukee River and the Kinnickinnic River both have several known areas of PCB contamination, as documented in numerous reports, including Southeastern Wisconsin Regional Planning Commission (1987) and Steuer and others (1999). PCB contamination along the main stem of the Milwaukee River may be attributed to the Cedar Creek Superfund alternative site located upstream. PCB concentrations exceeding the TEC on the Menomonee River may be a result of former industrial land-use practices within the Menomonee River watershed (Southeastern Wisconsin Regional Planning Commission, 1987).
Concentrations of the nine contaminants shown in figure 57 (Phase II data) were compared separately to Phase I results (appendix 5). Comparisons were made with a limited number of sites. For almost all sediment trace elements (cadmium, chromium, copper, lead, mercury, nickel, and zinc), most sites indicated decreases in concentrations from Phase I to Phase II. The one exception was arsenic, which increased at most sites. Ever decreasing LOD's for PCB's may have allowed more detections of low-level PCB's. This greater analytical sensitivity over time is important to keep in mind when drawing comparisons between current and historical data. Many of the Phase I samples may have contained PCBs at concentrations undetectable by older laboratory methods (LOD $0.05 \mathrm{mg}$ / $\mathrm{kg}$ ), but which might have been detectable using current laboratory methods (LOD of $0.024 \mu \mathrm{g} / \mathrm{g}$ ). Data for total PCB concentrations in sediment were available for Phase I and Phase II comparisons at four sites (appendix 5). During Phase I, PCBs were detected in samples from three of the sites; no PCBs were detected in the single sample from Little Menomonee River. During Phase II, two of the four sites had concentrations detectable at the previous WSLH LOD: Little Menomonee River $(0.06 \mathrm{mg} / \mathrm{kg})$ and Menomonee River at Wauwatosa $(0.12 \mathrm{mg} / \mathrm{kg})$.

Table 23. Maximum total polychlorinated biphenyl (PCB) concentrations in sediment-trap samples for 15 Phase II stream sites collected during two surveys (June 2004 and April 2005) of the Milwaukee Metropolitan Sewerage District Corridor Study.

[mg/kg, milligram per kilogram; <, less than; --, not available; bold indicates concentrations that met or exceeded the threshold effect concentration (TEC) of $0.060 \mathrm{mg} / \mathrm{kg}$ (MacDonald and others, 2000]

\begin{tabular}{lc}
\hline \multicolumn{1}{c}{ Site name } & $\begin{array}{c}\text { Maximum total PCB result } \\
(\mathbf{m g} / \mathbf{k g})\end{array}$ \\
\hline Milwaukee River near Cedarburg & $\mathbf{0 . 3 0}$ \\
Lincoln Creek at 47th Street at Milwaukee & .03 \\
Milwaukee River at Milwaukee & $\mathbf{1 . 1}$ \\
Willow Creek at Maple Road near Germantown & .03 \\
Menomonee River at Menomonee Falls & .02 \\
Little Menomonee River at Milwaukee & .06 \\
Underwood Creek at Wauwatosa & .04 \\
Honey Creek at Wauwatosa & .05 \\
Menomonee River at Wauwatosa & $\mathbf{. 2 2}$ \\
Kinnickinnic River at S. 11th Street at Milwaukee & $-{ }^{\text {a }}$ \\
Milwaukee River at Mouth at Milwaukee & $\mathbf{1 . 2}$ \\
Oak Creek at South Milwaukee & .03 \\
Root River at Grange Avenue at Greenfield & .05 \\
Root River near Franklin & $<.02$ \\
Jewel Creek at Muskego & .02 \\
\hline
\end{tabular}

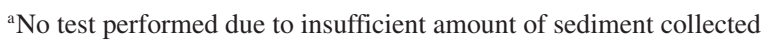




\section{Comparison of Sites by Use of Total Phosphorus Enrichment}

Phosphorus concentrations also were measured in conjunction with sediment sampling. In order to show the level of enrichment above background levels (that is, upland soil content), observed concentrations were divided by the average soil-sample total-phosphorus result ( 38.75 $\mathrm{mg} / \mathrm{kg}$ ) for Waukesha, Milwaukee, Ozaukee, and Washington Counties reported by Combs and Peters at the University of Wisconsin-Madison Soil \& Plant Analysis Lab between 1995 and 1999 (n.d.). The resulting enrichment factors (expressed as a ratio) for samples varied widely between sites, ranging from 4.8 at the Menomonee River at Wauwatosa site to 55 at the Milwaukee River at Mouth site (fig. 58). The total phosphorus concentration in sedimenttrap samples reflected the overlapping influences of urban and rural nonpoint-source pollution, and point-source inputs from treatment plants, combined and sanitary sewer overflows, cooling-water discharges, and phosphorus associated with soil erosion.

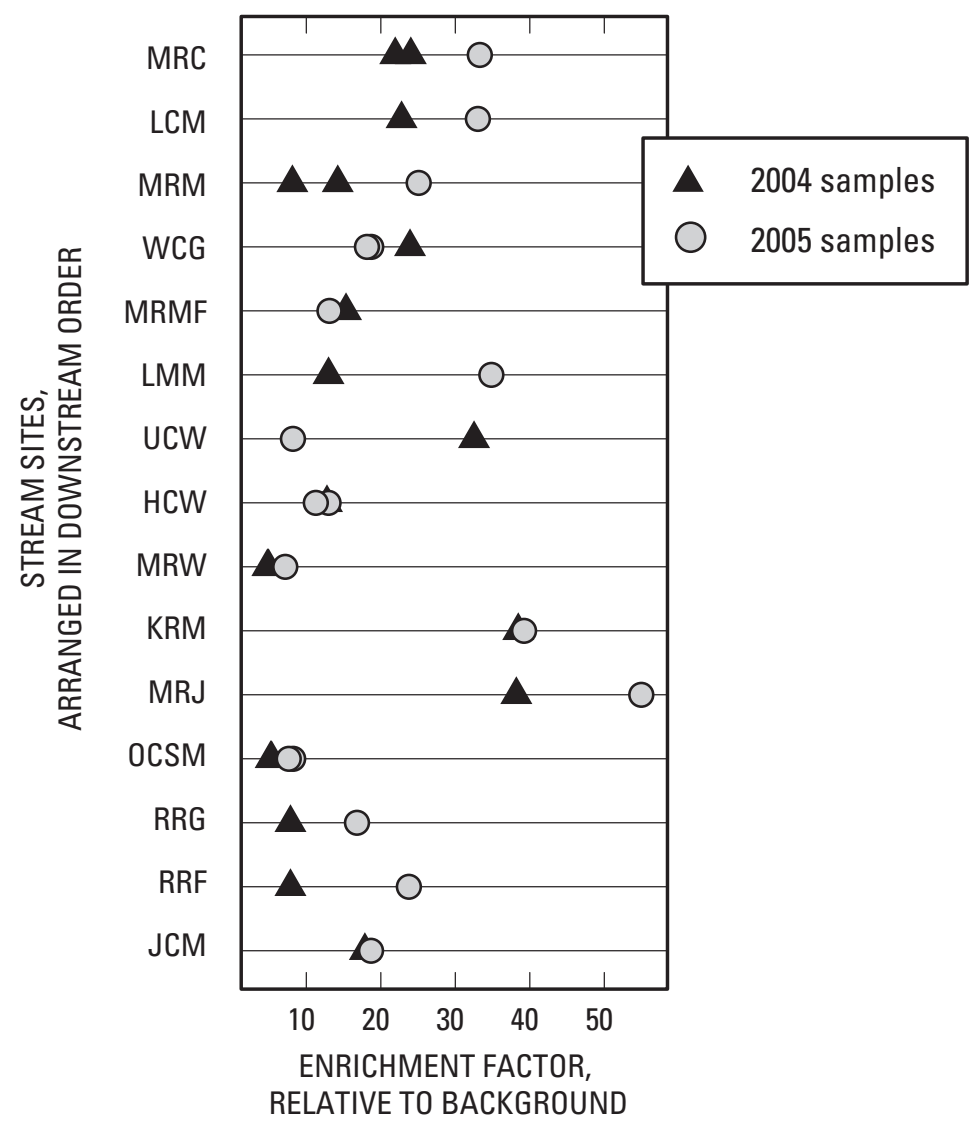

Figure 58. Total phosphorus enrichment factor relative to background upland soil concentrations in the Milwaukee Metropolitan Sewerage District planning area, Wis. Site abbreviations listed in table 1. 


\section{Water-Column Toxicity}

The Microtox Acute Toxicity Test has different sensitivities to different pollutants, with generally more sensitivity to organic pollutants than metals (Qureshi and others, 1998). Microtox analysis quantifies differences (in percent effect) of the fluorescence values of bioluminescent bacteria exposed to sample water when compared to a laboratory control. Decreases in fluorescence (positive percent effect values) are attributed to the toxic effects of sample water on the viability of test bacteria, and the magnitude of the change in luminescence relates positively to the toxicity of the sample water. Toxicity results are generally reported in one of two ways, depending on the level of toxicity in the sample. For samples with low toxicity, values are reported as the percent effect observed on analyses run with undiluted sample water (Chang and others, 1981). For more highly toxic samples, toxicities are generally reported as the $\mathrm{EC}_{50}$ or the concentration of sample water necessary to cause a 50-percent decrease in luminescence (when compared to laboratory controls) (Chang and others, 1981). The $\mathrm{EC}_{50}$ is computed by running a series of Microtox tests with different dilutions of sample water; at least one of these dilutions should cause less than a 35-percent effect, and at least one of the dilutions should cause greater than a 65-percent effect (Rand and Petrocelli, 1985).

Samples submitted for Microtox analysis were collected from all 21 Phase II sites during summer-quarterly and event sampling, yielding a total of 4 samples per site over the 2-year period. Analyses were first run with undiluted sample water, and values were reported as percent effect. Values were consistently below 20-percent effect, with a small number of samples exhibiting a greater effect. All environmental samples showing greater than 20-percent effect were collected from harbor sites (table 24). The maximum percent effect observed (40-percent effect) was well below the 65-percent effect needed for the determination of an $\mathrm{EC}_{50^{\circ}}$ Overall, results were not indicative of highly toxic conditions at any site.

Microtox analyses were also performed on extracts from SPMDs deployed at selected sites and these data are discussed elsewhere in this report. Results from those analyses reflect toxicities of hydrophobic compounds accumulated from the water column over a month.

\section{Fish Tissues}

Chemical concentrations in aquatic organisms are of interest not only for learning what may be accumulating in their tissues and potentially causing harm but also for estimating potential threats to other organisms, including birds and humans, who eat the contaminated organisms. Tissue analyses also serve as estimates of the chemical forms and concentrations that are biologically available for uptake. Fish were collected at three sites in early October 2004 for analysis of chemical concentrations. Green sunfish were collected at the Root River near Franklin and Milwaukee River at Milwaukee sites, and creek chubs were collected at the Root River near Franklin and at the Menomonee River at Wauwatosa sites. Three to five fish of a single species were composited for a site and analyzed by the WSLH.

Concentrations of chromium and lead in whole fish were below analytical reporting levels $(0.2$ and $0.8 \mu \mathrm{g} / \mathrm{g}$ wet weight, respectively)(table 25). Copper concentrations were at least 10 times higher in whole fish from Milwaukee River at Milwaukee and Menomonee River at Wauwatosa than in whole fish from Root River near Franklin.

Table 24. Percent effects in samples with readings at or above 20 percent for all Phase II sites in the Milwaukee Metropolitan Sewerage District planning area, Wis.

[All values in percent effect]

\begin{tabular}{lccc}
\hline \multicolumn{1}{c}{ Harbor site name } & Site abbreviation & 5-minute percent effect & 15-minute percent effect \\
\hline South Mid-Harbor Milwaukee Outer Harbor Site & OH-11 & 8 & 21 \\
Northern Outside Harbor Breakwall Lake Site & OH-12 & 24 & 22 \\
Middle Outside Harbor Breakwall Lake Site & OH-14 & 40 & 28 \\
Southern Outside Harbor Breakwall Lake Site & OH-13 & 35 & 33 \\
\hline
\end{tabular}




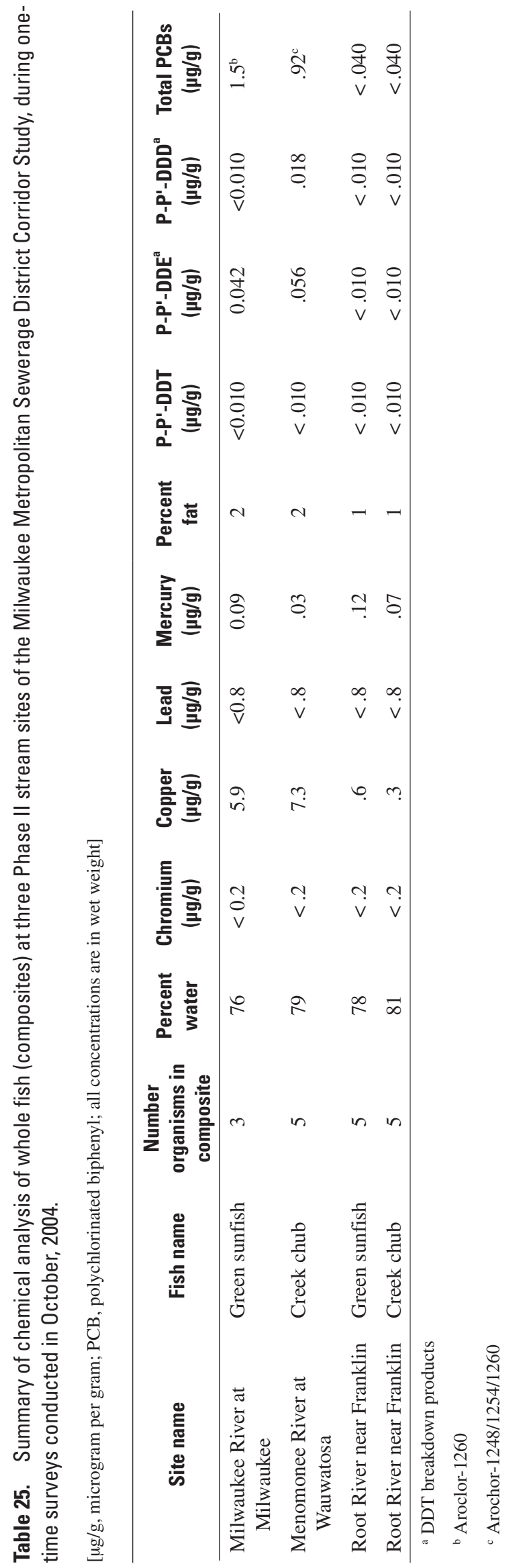


Mercury was detected in whole fish from all three sites at low total mercury ${ }^{5}$ concentrations $(0.03-0.12 \mu \mathrm{g} / \mathrm{g}$ wet weight) and was below the USEPA methylmercury criterion of $0.3 \mu \mathrm{g} / \mathrm{g}$ wet weight in fish (U.S. Environmental Protection Agency, 2001).

The synthetic organic contaminants chlordane and dieldrin were not detected (less than 0.010 micrograms per gram wet weight) in whole fish. DDT breakdown products p-p'-DDE and p-p'-DDD were detected in whole fish from Menomonee River at Wauwatosa, and p-p'DDE was detected in whole fish from Milwaukee River at Milwaukee; however, concentrations were still less than available guidelines for protection of sensitive fish-eating wildlife. Although the insecticide DDT has not been used in the United States for decades, the breakdown products DDE and DDD are known to be persistent in the environment from historical use. PCBs were not detected in fish from Root River near Franklin (less than $0.040 \mu \mathrm{g} / \mathrm{g}$ wet weight); however, PCBs were found in relatively high concentrations in fish from the Menomonee River site and the Milwaukee River at Milwaukee site. Although manufacture of PCBs ended in 1977, the PCBs found were Aroclors or common mixtures of PCB compounds, indicating that high concentrations persist in stream sediment and accumulate in fish and wildlife. A concentration of 1.5 $\mu \mathrm{g} / \mathrm{g}$ wet weight of Aroclors 1248/1254/1260 in whole green sunfish from Milwaukee River at Milwaukee exceeded the New York guideline for the protection of fish-eating wildlife of $0.11 \mu \mathrm{g} / \mathrm{g}$ wet weight for total PCBs (Newell and others, 1987). This indicates that wildlife eating fish from this site could be at risk. The PCB concentration from Milwaukee River fish is similar to that found in whole fish $(1.6 \mu \mathrm{g} / \mathrm{g}$ wet weight total PCBs) in 1995 by Scudder and others (1997) and was high compared to concentrations at other sampled sites in the Milwaukee area (Scudder and others, 1997; Steuer and others, 1999); PCB contamination along the main stem of the Milwaukee River may be attributed to the Cedar Creek Superfund alternative site located upstream. Toxicity of specific Aroclor mixtures can vary greatly but the Arochlors detected are considered to be particularly toxic as immunotoxins and carcinogens. Fish consumption is the most common reason for high PCB concentrations in humans. A fishconsumption advisory for PCBs has been in affect at the Milwaukee River at Milwaukee site since 1980 and at the
Menomonee River at Wauwatosa site since 1984 (Candy S. Schrank, Wisconsin Department of Natural Resources, written commun., 2006; Wisconsin Department of Natural Resources, 2006).

Comparisons between Phase I and Phase II results for pesticides and PCBs were available for three sites: Milwaukee River at Milwaukee, Menomonee River at Wauwatosa, and Root River near Franklin (appendix 5). Improvement in analytical equipment and techniques for these constituents have allowed for ever-decreasing reporting levels, thereby allowing more low-level concentrations to be detected. This greater analytical sensitivity over time is important to keep in mind when drawing comparisons between Phase I and Phase II data. Many of the Phase I samples below reporting level likely contained pesticides and PCBs at concentrations undetectable by older analytical methods (reporting levels of 0.05 and $0.2 \mu \mathrm{g} / \mathrm{g}$, respectively), but which might have been detectable using current analytical methods (reporting levels of 0.01 and $0.04 \mu \mathrm{g} / \mathrm{g}$, respectively).

During Phase I, pesticides in fish tissues were detected only in samples collected from the Lower Milwaukee River subwatershed. During Phase II pesticide concentrations in fish tissues were below the Phase I reporting level at Milwaukee River at Milwaukee, but above the Phase I reporting level at Menomonee River at Wauwatosa. No detections were observed during either Phase at Root River near Franklin.

During Phase I, PCBs were detected only in samples collected from the Lower Milwaukee River subwatershed. During Phase II, PCB concentrations in fish tissues were above the Phase I reporting level at both Milwaukee River at Milwaukee and Menomonee River at Wauwatosa. No detections were observed during either Phase at Root River near Franklin.

\footnotetext{
${ }^{5}$ Between 95 and 99 percent of the mercury in fish tissue is typically methylmercury (Wiener and Spry, 1996).
} 


\section{Bioassessment}

Community structure of the aquatic biota-including fish, macroinvertebrates (especially the aquatic larvae of many insects), and algae-is a useful indicator of water quality. Aquatic-community data often are used to assess and monitor environmental quality in an approach termed "bioassessment" or "biomonitoring" (Plafkin and others, 1989). Metrics or numerical indices, based on the distribution and abundance of species, have been used for decades by agencies and citizen-monitoring groups to provide a time-integrated picture of water quality and the responses of aquatic biota. Use of multiple trophic levels and metrics in any evaluation is important because no single metric can adequately reflect the many possible types of effects that can result from changes in water quality. Collection of associated habitat information is important to help differentiate effects due to water-chemistry change from effects due to habitat degradation.

\section{Fish Results}

The use of fish-community data for bioassessment and biomonitoring techniques has been shown to be a useful way to detect and quantify environmental degradation in aquatic systems (Lyons, 1992). An Index of Biotic Integrity (IBI) for warmwater streams in Wisconsin (Lyons, 1992) was used for the data collected at the 14 wadeable streams sites (table 26). The Wisconsin version of the IBI was largely derived from the Ohio Environmental Protection Agency "wading sites" version (Ohio Environmental Protection Agency, 1988) of the IBI. The Ohio version in turn was a modified version of the IBI developed during the late 1970s and early 1980s to assess biotic integrity and environmental quality in small streams in Indiana and Illinois (Karr, 1981; Karr and others, 1986). The IBI consists of a series of fish community attributes, or metrics, that reflect basic structural and functional characteristics of biotic assemblages: species richness and composition, trophic and reproductive function, and individual abundance and condition (Lyons, 1992). The Wisconsin version of the IBI consists of 10 basic metrics and 2 correction factors. The IBI is predicated on the assumption that the number of species in a community declines with increasing environmental degradation.
Table 26. Biotic integrity ratings for Index of Biotic Integrity score (modified from Karr and others, 1986).

\begin{tabular}{cc}
\hline IBI score & Biotic integrity rating \\
\hline $100-65$ & Excellent \\
$64-50$ & Good \\
$49-30$ & Fair \\
$29-20$ & Poor \\
$19-0$ & Very poor \\
no score & Very poor \\
\hline
\end{tabular}

Of the 14 wadeable sites sampled, IBI scores for fish could not be reliably computed at 3 sites because only a small number of fish were collected (table 27). If fewer than 50 fish are collected at a site, the Wisconsin warmwater IBI should not be used in assessing the fish-community data (Lyons, 1992). IBI scores were computed for the remaining 11 sites: 6 scored very poor; 2 were poor; and 1 each was fair, good, and excellent (table 27).

The two Milwaukee River main-stem sites had the highest IBI scores, with all other sites scoring poor or very poor. Two of the individual metrics included in the Wisconsin IBI are "percent of fish tolerant to low dissolvedoxygen levels" and "percent of fish tolerant to disturbed habitat." All but four sites (Milwaukee River at Milwaukee, Milwaukee River near Cedarburg, Willow Creek, and Jewel Creek) had more than 50 percent of the fish community in 1 of these 2 metrics, indicating a high percentage of fish in the population that are tolerant of degraded stream conditions.

Fish IBI scores indicated a negative relation to urban land use, where fish IBI scores decreased as urban land use increased (fig. 59). Phase I IBI scores were computed on data collected from 1990 through 2002. Data were available for Phase I and Phase II fish IBI score comparisons at six sites (appendix 5). Of these, four sites remained in the same category as was determined by the Phase I data (all very poor). However, Kinnickinnic River and Honey Creek both went from poor in Phase I to very poor in Phase II. 
Table 27. Fish-community information from one-time surveys conducted during July, August, and October 2004, for 14 Phase II stream sites in the Milwaukee Metropolitan Sewerage District planning area, Wis.

[*, fewer than 50 individual fish were collected, so the Wisconsin warmwater Index of Biotic Integrity was not used (Lyons, 1992)]

\begin{tabular}{|c|c|c|c|c|c|c|}
\hline \multirow{2}{*}{ Site name } & \multirow{2}{*}{$\begin{array}{c}\text { Total } \\
\text { number } \\
\text { of fish }\end{array}$} & \multirow{2}{*}{$\begin{array}{c}\text { Total } \\
\text { number of } \\
\text { fish species }\end{array}$} & \multirow{2}{*}{$\begin{array}{c}\text { Percent fish } \\
\text { tolerant of } \\
\text { low dissolved } \\
\text { oxygen }\end{array}$} & \multirow{2}{*}{$\begin{array}{c}\text { Percent fish } \\
\text { tolerant to } \\
\text { disturbed } \\
\text { habitat }\end{array}$} & \multicolumn{2}{|c|}{$\begin{array}{c}\text { Index of } \\
\text { Biotic Integrity }\end{array}$} \\
\hline & & & & & Score & Rating \\
\hline Milwaukee River near Cedarburg & 319 & 22 & 9 & 4 & 70 & Excellent \\
\hline Lincoln Creek at 47th Street at Milwaukee & 48 & 8 & 84 & 0 & $*$ & Very poor \\
\hline Milwaukee River at Milwaukee & 224 & 18 & 31 & 6 & 60 & Good \\
\hline Willow Creek at Maple Road near Germantown & 238 & 6 & 36 & 24 & 25 & Poor \\
\hline Menomonee River at Menomonee Falls & 241 & 13 & 40 & 50 & 30 & Fair \\
\hline Little Menomonee River at Milwaukee & 14 & 5 & 69 & 31 & $*$ & Very poor \\
\hline Underwood Creek at Wauwatosa & 211 & 8 & 8 & 92 & 10 & Very poor \\
\hline Honey Creek at Wauwatosa & 135 & 6 & 16 & 84 & 7 & Very poor \\
\hline Menomonee River at Wauwatosa & 118 & 3 & 11 & 87 & 12 & Very poor \\
\hline Kinnickinnic River at S. 11th Street at Milwaukee & 11 & 1 & 100 & 0 & $*$ & Very poor \\
\hline Oak Creek at South Milwaukee & 207 & 7 & 17 & 83 & 10 & Very poor \\
\hline Root River at Grange Avenue at Greenfield & 174 & 9 & 28 & 66 & 12 & Very poor \\
\hline Root River near Franklin & 122 & 12 & 3 & 84 & 14 & Very poor \\
\hline Jewel Creek at Muskego & 514 & 15 & 15 & 46 & 22 & Poor \\
\hline
\end{tabular}

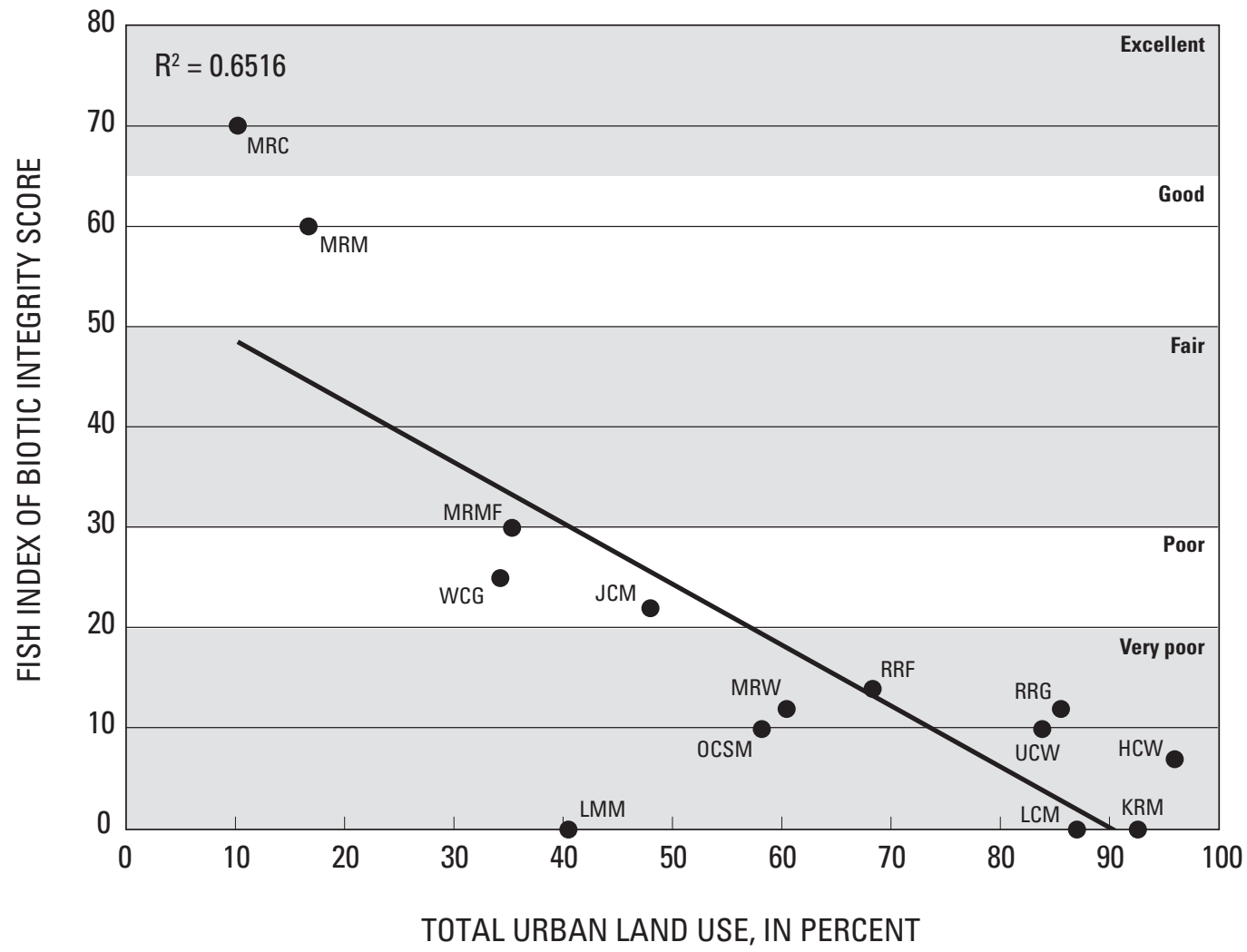

Figure 59. Fish Index of Biotic Integrity (IBI) scores plotted against percent urban land use in site drainage basins for 15 stream sites in the Milwaukee Metropolitan Sewerage District planning area, Wis. Site abbreviations listed in table 1. 


\section{Macroinvertebrate Results}

Selected metrics were computed based on macroinvertebrates found at each site. These metrics included the number of macroinvertebrate species and genera, Shannon index of diversity (Odum, 1971), the percentage of macroinvertebrate individuals or genera in the orders Ephemeroptera-Plecoptera-Trichoptera (EPT), and the Hilsenhoff Biotic Index (HBI) and 10-Max BI (HBI-10). Taxa (species and genera) would be expected to decrease with degrading water quality. Shannon index of diversity scores generally decrease with degrading water quality; however, pristine headwater streams may have low diversity and excellent water quality. EPT invertebrates are generally considered to be relatively intolerant of water-quality degradation. Intolerant organisms tend to dominate in streams with good water quality, whereas tolerant organisms dominate in polluted streams; therefore, the percentage of EPT individuals and genera tend to decrease with decreasing water quality. The HBI was designed to assess oxygen depletion in streams resulting from organic-matter pollution (Hilsenhoff, 1987); however, the HBI also may be sensitive to other types of pollution, such as that from some chemicals. The HBI represents the number of arthropod macroinvertebrates in certain families or species, multiplied by their respective pollution-tolerance score, divided by the number of arthropods in the sample. HBI values can range from 0.00 (excellent water quality) to 10.00 (very poor water quality) (table 28). A modification of the HBI (HBI-10) was used in the Phase II analyses because it limits the number of individuals per taxa to 10 for computation of the index and is thought to be more accurate than the HBI because it is less affected by dominance of a single taxon (Hilsenhoff, 1998).

The Milwaukee River near Cedarburg and Milwaukee River at Milwaukee sites had the highest numbers of macroinvertebrate species and genera; these sites also had the highest Shannon index of diversity scores (greater than 3.6), along with Willow Creek, a much smaller stream (table 29). The Lincoln Creek, Menomonee River at Menomonee Falls, and Menomonee River at Wauwatosa sites had the fewest species and genera. The lowest Shannon index of diversity scores were found at the Menomonee River at Menomonee Falls and the Little Menomonee River sites. This finding suggested that the water quality at these sites was more degraded than at other sampled sites.
Sites with the lowest EPT percentages (EPT individuals $<30$ percent and EPT taxa $<10-20$ percent) were the Kinnickinnic River (lowest overall), Honey Creek, Root River at Grange Avenue, and Lincoln Creek sites (table 29). Historically, the Middle and Lower Root River Phase I subwatersheds had much higher median EPT percentages than the Upper Root River or East Branch Root River subwatersheds (fig. 60), suggesting that the lower subwatersheds had less-degraded water quality. The August 2004 sample for Root River near Franklin (Middle Root River subwatershed) had a much lower percentage of EPT taxa (28 percent) compared to historical percentages (median of 50 percent EPT taxa). Further investigation of the macroinvertebrate communities in the Middle Root River may be warranted to determine whether water quality has declined notably. On the other hand, historical data indicated that EPT taxa were few or absent from the Lincoln Creek Phase I subwatershed, but samples from August 2004 indicated a higher percentage of EPT taxa (18 percent) possibly indicating improved water quality. The Little Menomonee River subwatershed also indicated a higher percentage of EPT taxa (23 percent) in the Phase II sample; however, this result may be misleading since the sample contained a high proportion of a pollution-tolerant Ephemeroptera species (Baetis intercalaris). Percent EPT taxa indicated a negative relation to urban land use, where percent EPT taxa decreased with increasing urban land use (fig. 61).

Table 28. Water-quality ratings for Hilsenhoff Biotic Index (HBI) and HBI-10 values (from Hilsenhoff, 1987 and 1998).

$[\leq$, less than or equal to]

\begin{tabular}{cc}
\hline HBI/HBI-10 value & Water-quality rating \\
\hline$\leq 3.50$ & Excellent \\
$3.51-4.50$ & Very good \\
$4.51-5.50$ & Good \\
$5.51-6.50$ & Fair \\
$6.51-7.50$ & Fairly poor \\
$7.51-8.50$ & Poor \\
$8.51-10.00$ & Very poor \\
\hline
\end{tabular}


HBI-10 scores for August 2004 samples ranged from fairly poor water quality at the Kinnickinnic River site to fair or good at other sampled sites (fig. 62). Sites with fair HBI-10 scores were Lincoln Creek, Menomonee River at Menomonee Falls, Menomonee River at Wauwatosa, Underwood Creek, Jewel Creek, Oak Creek, Root River at Grange Avenue, and Root River near Franklin. Sites with good HBI-10 scores were those in the middle and upper part of the planning area, specifically Willow Creek, Little Menomonee River, Honey Creek, Milwaukee River near Cedarburg and Milwaukee River at Milwaukee. Scores for Little Menomonee River and Honey Creek were anomalously high when compared with data for other biological metrics (table 29). High HBI-10 scores at Little Menomonee River are likely the result of the same predominant pollution-tolerant Ephemeroptera species that affected the EPT percentages; therefore, high HBI10 scores at this site may not be indicative of true water quality. Honey Creek's HBI-10 scores may be misleading, as all other macroinvertebrate metrics indicate a decline in water quality. HBI-10 scores indicated a positive relation with urban land use, where HBI-10 scores increased (indicating decreasing water quality) with increasing urban land use (fig. 63).

Table 29. Macroinvertebrate community information from one-time surveys conducted during August and September 2004, for 14 Phase II stream sites in the Milwaukee Metropolitan Sewerage District planning area, Wis.

[EPT, Ephemeroptera, Plecoptera, and Trichoptera; HBI-10, modified Hilsenhoff Biotic Index; see table 28 for explanation of HBI-10 water-quality ratings]

\begin{tabular}{|c|c|c|c|c|c|c|c|}
\hline \multirow[b]{2}{*}{ Site name } & \multirow{2}{*}{$\begin{array}{l}\text { Number of } \\
\text { species }\end{array}$} & \multirow{2}{*}{$\begin{array}{c}\text { Number of } \\
\text { genera }\end{array}$} & \multirow{2}{*}{$\begin{array}{l}\text { Shannon } \\
\text { index of } \\
\text { diversity }\end{array}$} & \multirow{2}{*}{$\begin{array}{c}\text { Percent } \\
\text { of EPT } \\
\text { individuals }\end{array}$} & \multirow{2}{*}{$\begin{array}{c}\text { Percent } \\
\text { of EPT } \\
\text { taxa }\end{array}$} & \multicolumn{2}{|c|}{ HBI-10 } \\
\hline & & & & & & Value & Rating \\
\hline Milwaukee River near Cedarburg & 45 & 39 & 3.860 & 75 & 51 & 5.01 & Good \\
\hline Lincoln Creek at 47th Street at Milwaukee & 20 & 17 & 3.057 & 31 & 18 & 6.30 & Fair \\
\hline Milwaukee River at Milwaukee & 46 & 41 & 3.698 & 84 & 39 & 5.20 & Good \\
\hline Willow Creek at Maple Road near Germantown & 32 & 29 & 3.940 & 40 & 17 & 5.45 & Good \\
\hline Menomonee River at Menomonee Falls & 18 & 16 & 2.290 & 75 & 44 & 5.56 & Fair \\
\hline Little Menomonee River at Milwaukee & 23 & 22 & 2.275 & 57 & 23 & 5.33 & Good \\
\hline Underwood Creek at Wauwatosa & 33 & 28 & 2.713 & 72 & 18 & 5.96 & Fair \\
\hline Honey Creek at Wauwatosa & 24 & 24 & 2.730 & 29 & 17 & 5.28 & Good \\
\hline Menomonee River at Wauwatosa & 20 & 16 & 2.683 & 75 & 31 & 5.86 & Fair \\
\hline Kinnickinnic River at S. 11th Street at Milwaukee & 34 & 27 & 3.018 & 18 & 7.0 & 6.52 & Fairly poor \\
\hline Oak Creek at South Milwaukee & 28 & 23 & 2.856 & 78 & 22 & 5.55 & Fair \\
\hline Root River at Grange Avenue at Greenfield & 23 & 22 & 2.686 & 30 & 18 & 6.15 & Fair \\
\hline Root River near Franklin & 31 & 25 & 3.346 & 63 & 28 & 5.92 & Fair \\
\hline Jewel Creek at Muskego & 28 & 24 & 3.072 & 45 & 29 & 5.58 & Fair \\
\hline
\end{tabular}




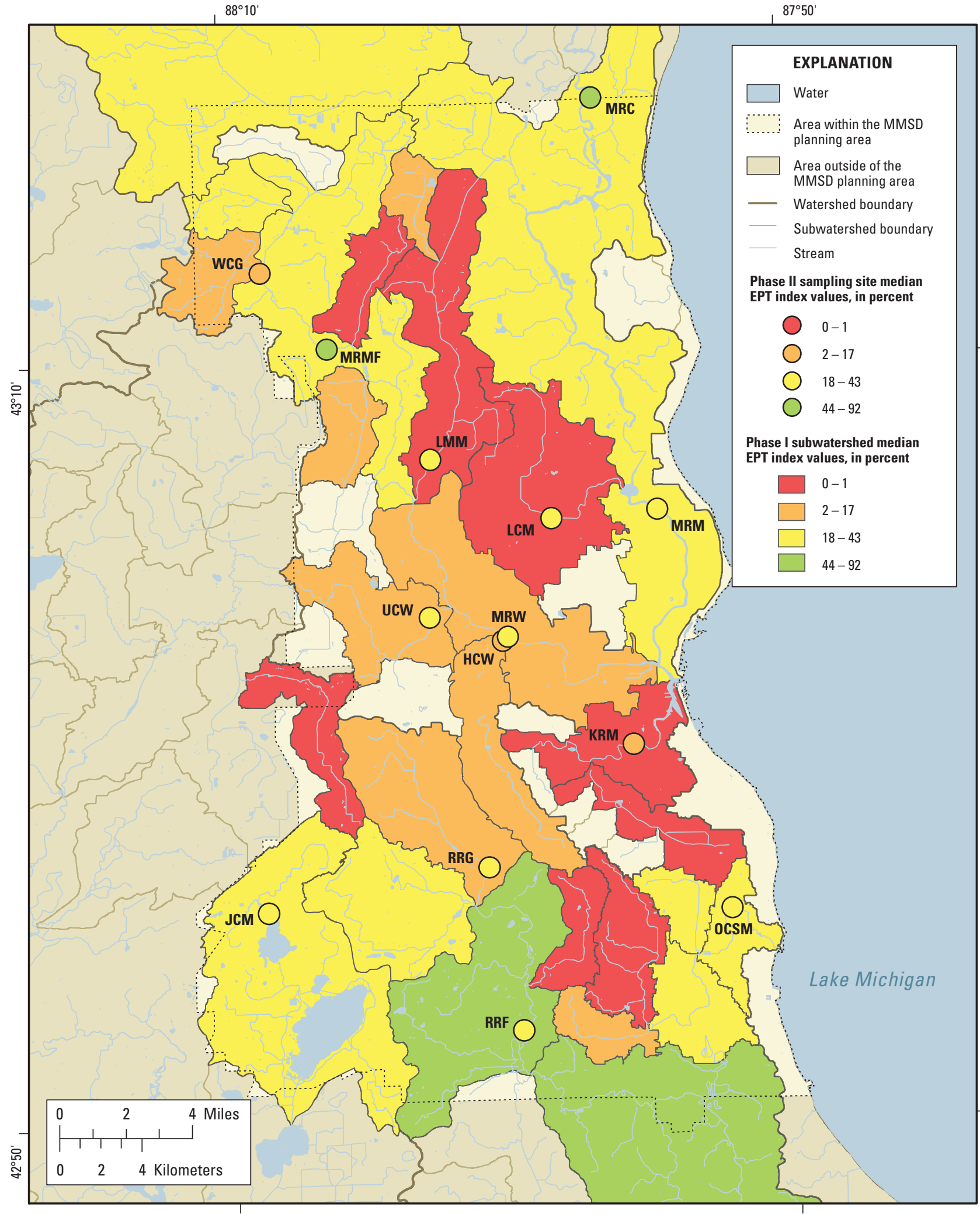

Base composited from Southeastern Wisconsin Regional Planning Commission regional base map, 1:2,000, 1995; U.S. Geological Survey digital line graph hydrography, 1:100,000, 1989; Wisconsin Department of Natural Resources version 2 hydrography, 1:24,000, 2002. Wisconsin Transverse Mercator Projection, referenced to North American Datum of 1983, 1991 adjustment.

Figure 60. Sites sampled for macroinvertebrates with percent Ephemeroptera, Plecoptera, and Trichoptera (EPT) taxa in the Milwaukee Metropolitan Sewerage District (MMSD) planning area, Wis. Site abbreviations listed in table 1. 


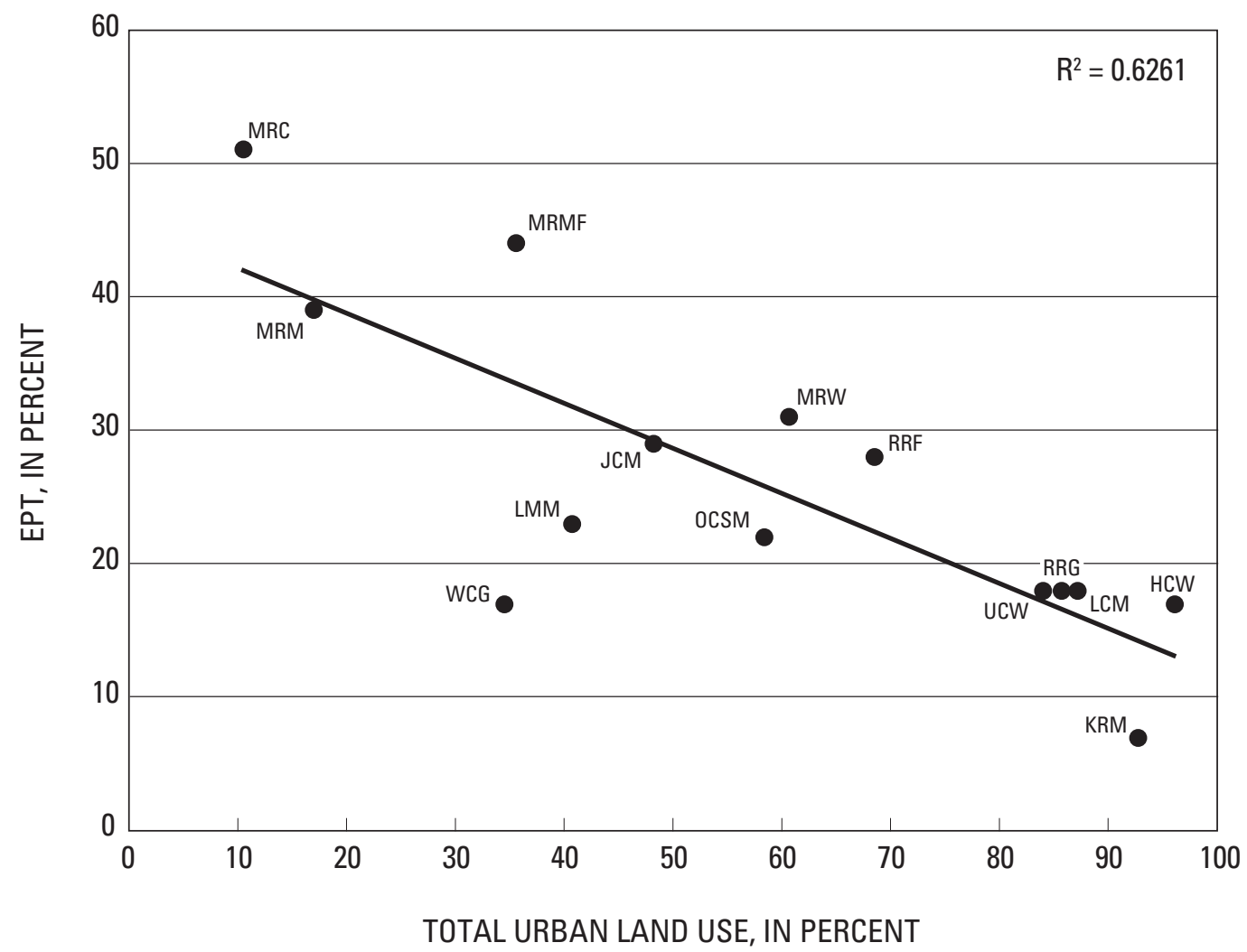

Figure 61. Percent Ephemeroptera, Plecoptera, and Trichoptera (EPT) taxa plotted against percent urban land use in site drainage basins for 15 stream sites in the Milwaukee Metropolitan Sewerage District planning area, Wis. Site abbreviations listed in table 1. 


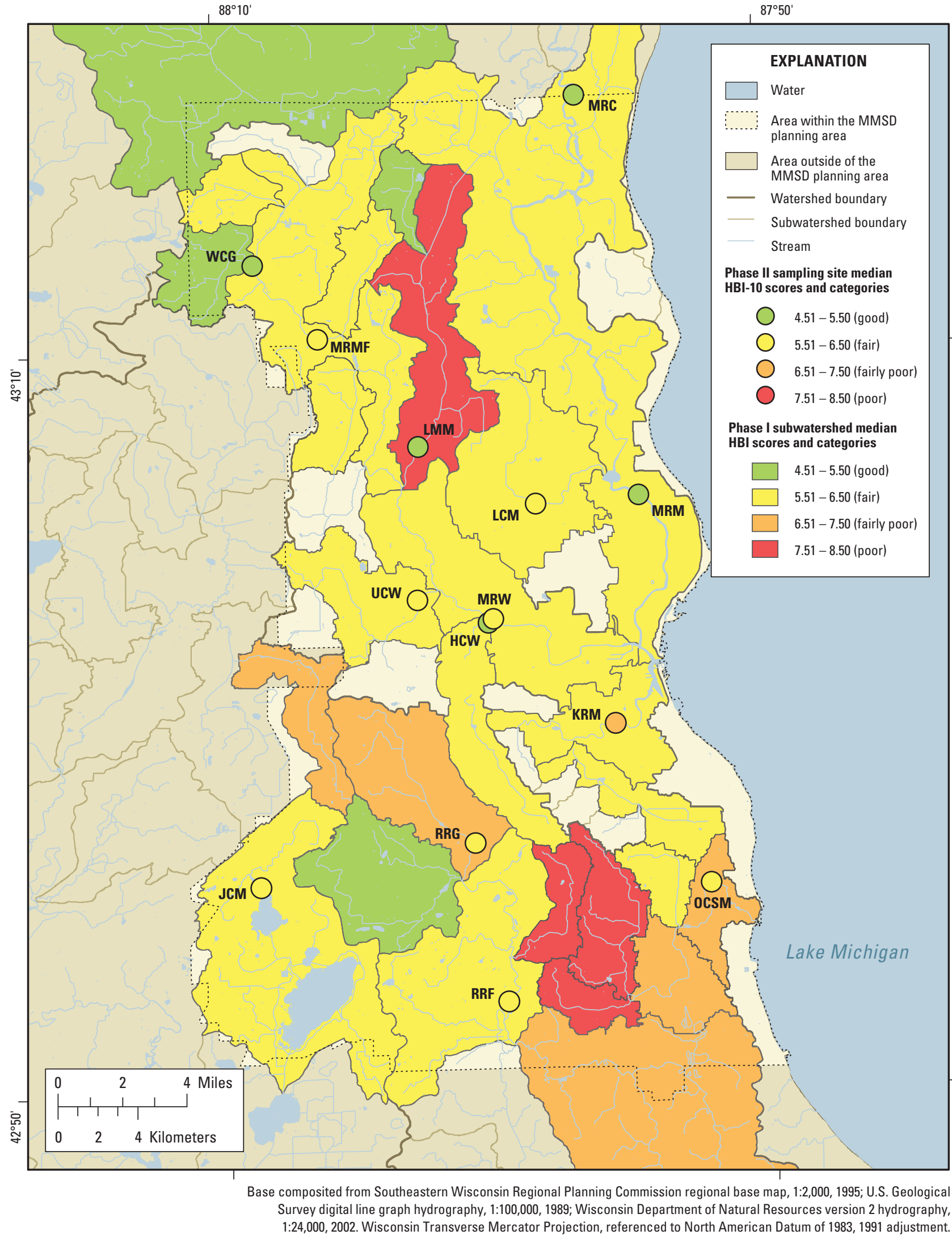

Figure 62. Sites sampled for macroinvertebrates with Hilsenhoff Biotic Index (HBI) in the Milwaukee Metropolitan Sewerage District (MMSD) planning area, Wis. See table 28 for more information on HBI water-quality ratings. Site abbreviations listed in table 1. 


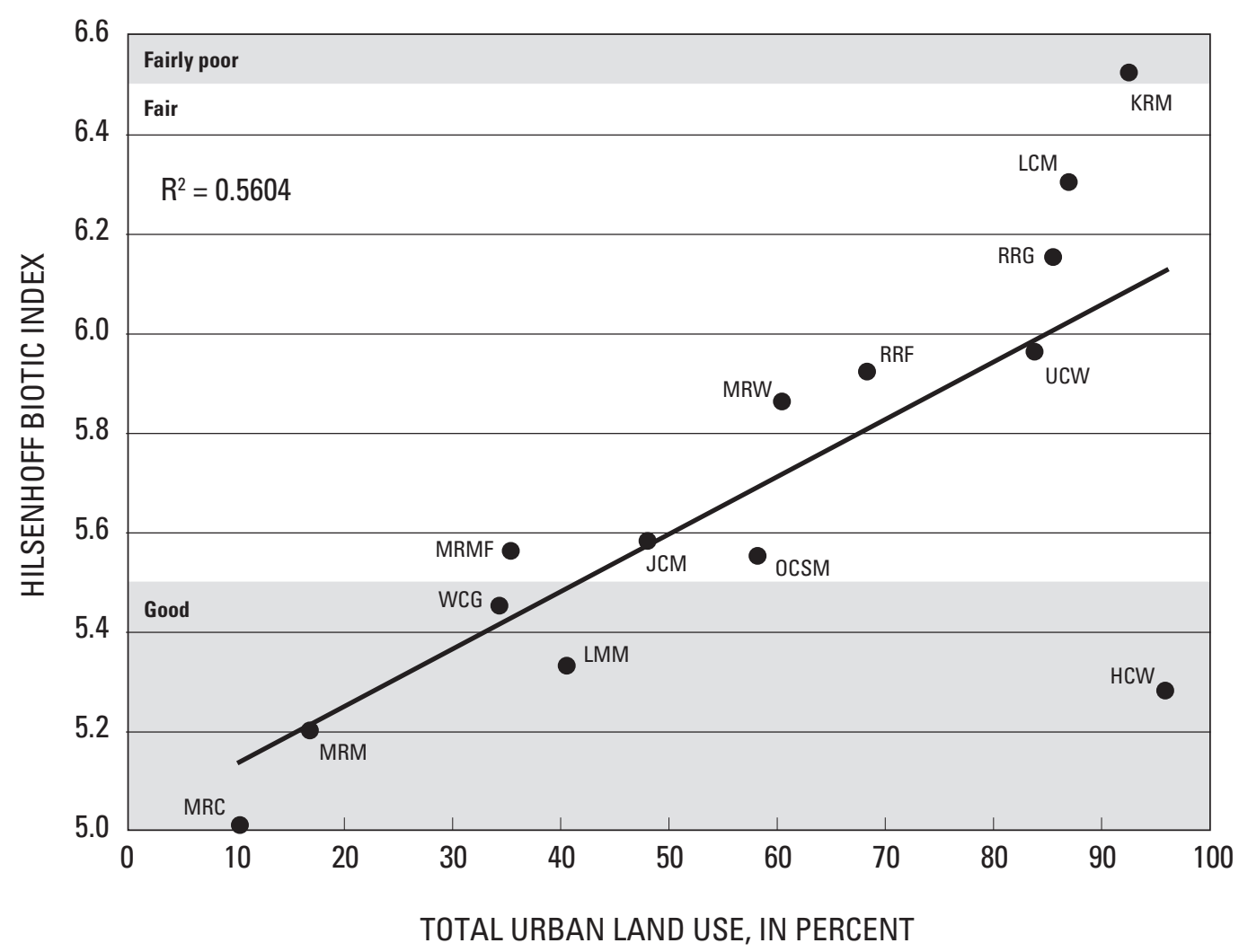

Figure 63. A modified Hilsenhoff Biotic Index (HBI-10) plotted against percent urban land use in site drainage basins for 15 stream sites in the Milwaukee Metropolitan Sewerage District planning area, Wis (Hilsenhoff, 1998). Site abbreviations listed in table 1.

\section{Algae Results}

Attached benthic algae (periphyton) are often the dominant primary carbon producers and energy source for food chains in small- to medium-sized streams. The term "periphyton" refers to the collection of the attached benthic algae and other heterotrophic bacteria or microbes that are affixed to the submerged substrata in freshwater systems. The abundance and species diversity of periphyton provides valuable information on water quality in a particular stream reach. Periphyton can be used to develop indicator indices in a manner similar to those for macroinvertebrates and fish.

The percent relative abundance (PRA) of each algal group (blue-green algae, diatoms, green algae, red algae) is the number of cells present of the algal group divided by the total number of algal cells. Blue-green algae had the highest PRA at Menomonee River at Wauwatosa (90.98 percent) and diatoms were dominant at Willow Creek (PRA of 58.74 percent)(table 30). Green algae were found at only eight sites, with Lincoln Creek having the highest
PRA (3.65 percent). Red algae were also found at eight sites, with Root River at Greenfield and Root River near Franklin having the highest PRA (86.92 percent and 51.72 percent, respectively). Algal group PRAs indicated no appreciable relation to urban land use.

Percent biovolume of an algal group is determined by multiplying the number of algal cells by the volume of space each cell occupies, divided by the total biovolume of the algal cells. The percent biovolume for a group of algae can be drastically different than the PRA because of the size of the cells. Blue-green algae may have been the most abundant in the count; however those algae occupied very small amounts of volume compared to other groups such as diatoms or green algae and therefore may not have had a high-percent biovolume. The most notable difference in biovolume composition from PRA occurred at Milwaukee River near Cedarburg, where blue-green algae composed 83.46 percent of the relative abundance but only 1.76 percent of the biovolume and green algae composed 0.41 percent of the relative abundance and 86.46 percent of the 


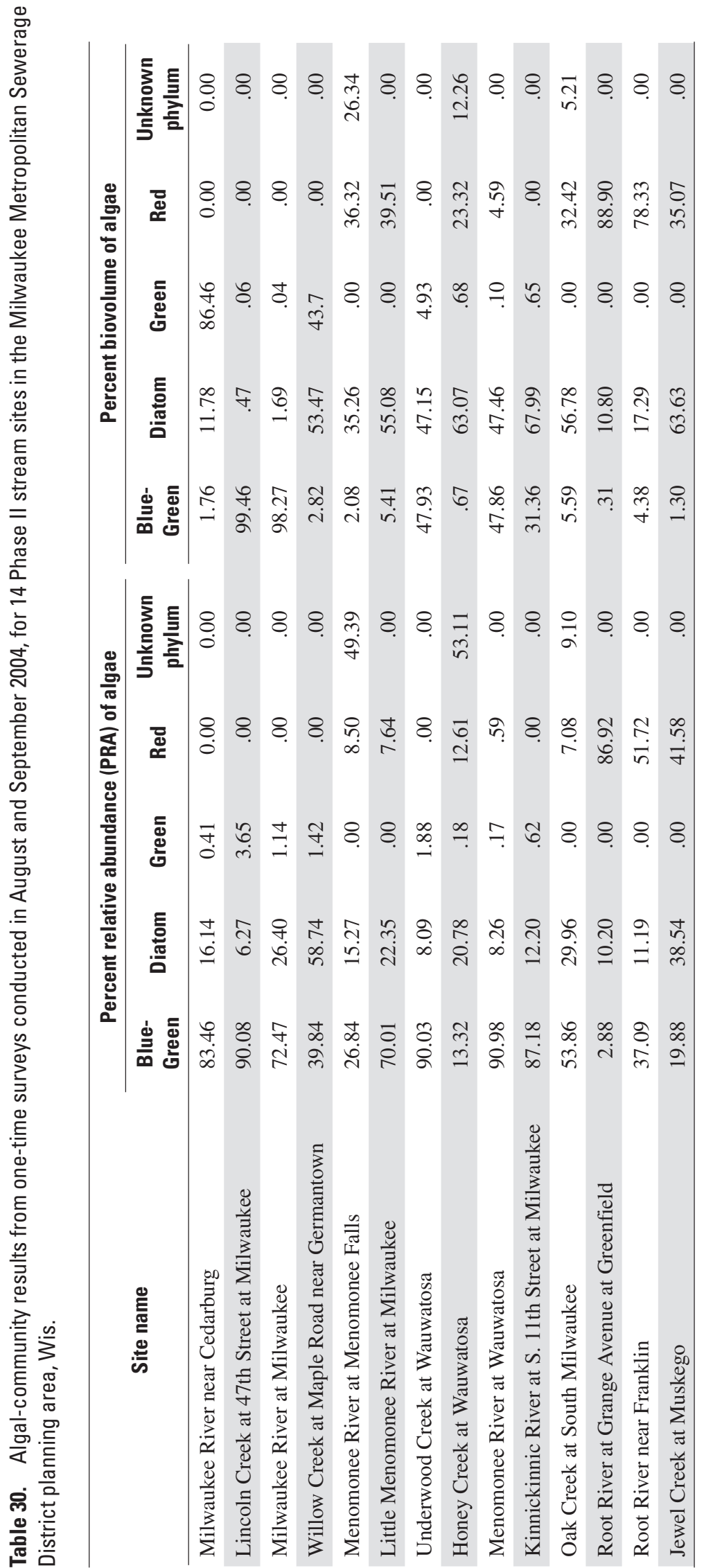


biovolume (table 30). Percent biovolumes of algal groups indicated no appreciable relation to urban land use.

Nuisance, bloom-producing algae were found only at Milwaukee River near Cedarburg (Cladophora glomerata) and Underwood Creek (Stigeoclonium lubricum). Both of these taxa are green algae that are common in Great Lakes-area streams and lakes with high nutrient loading, especially phosphorus (Prescott, 1962; Wehr and Sheath, 2003). On the basis of occurrence of nuisance algae and the pollution classes, these two streams were identified as possible areas of high nutrient loading and high concentrations of other pollutants.

Pollution-tolerance classes for diatoms ("Most pollution tolerant" and "Pollution sensitive" in figure 64) have been used as water-quality indicators in streams (LangeBertalot, 1979; Bahls, 1993). The classes are based on several variables such as nutrient concentration, saprobic conditions (organic rich, oxygen poor), biochemical oxygen demand (BOD), and toxics that each taxon can tolerate and are based on the percent relative abundance of each taxon in the sampled streams. Fewer pollution-sensitive taxa at a site indicate that at least one of the variables that make up the pollution-tolerance classes is elevated and not suited for pollution-sensitive diatoms (Bahls, 1993). Jewel Creek, Willow Creek, Milwaukee River near Cedarburg, and Root River near Franklin had the highest percentages of diatom-normalized relative abundances of pollutionsensitive diatoms all over 60 percent (fig. 64). Lincoln Creek and Kinnickinnic River had the lowest percentages of diatom-normalized relative abundances of pollutionsensitive diatoms both below 20 percent.

Streams with low percentages of pollution-sensitive diatoms indicate that at least one of the variables used to determine pollution sensitivity is elevated and that those streams cannot sustain a large community of pollutionsensitive taxa. Streams that have less than 30 percent pollution-sensitive diatoms are of concern because these streams may contain nutrients, such as phosphorus, that lead to high oxygen demand and eutrophication. The streams that had less than 30 percent pollution-sensitive diatoms were Lincoln Creek, Honey Creek, Menomonee River at Wauwatosa, and Kinnickinnic River. Pollutionsensitive diatom percentages indicated a negative relation to urban land use, where percentages decreased with increasing urban land use (fig. 65). Percentages of other pollution-tolerance classes for diatoms indicated no appreciable relation to urban land use.

\section{Relations among Habitat Variables and Biotic Communities}

The streams in the MMSD planning area exhibited considerable variation in their physical habitats, mainly because of the wide range in size of streams sampled. For example, mean wetted width of the sampled reaches ranged from less than $3 \mathrm{~m}$ at the site with the smallest drainage area (Willow Creek, $16.39 \mathrm{~km}^{2} / 6.33 \mathrm{mi}^{2}$ ) to almost $70 \mathrm{~m}$ at the site with the largest drainage area (Milwaukee River at Milwaukee, 1,787 km²/690 $\mathrm{mi}^{2}$ ). Mean depth ranged from $0.15 \mathrm{~m}$ at Willow Creek to $0.56 \mathrm{~m}$ at Milwaukee River at Milwaukee.

Correlations among biological metrics and habitat variables (table 31) were evaluated using Spearman's rank correlation (Iman and Conover, 1983). Results indicated that the larger streams had relatively higher-quality fish and macroinvertebrate communities than small streams; however, algal community metrics did not correlate with stream-size characteristics. Fish and macroinvertebrate communities were significantly correlated $(\mathrm{p}<0.05)$ with the stream-size variables: width-to-depth ratio, low flow volume, wetted channel area, bankfull channel area, and drainage area. Unexpectedly, streams with a high amount of bank erosion and a high percentage of pools had low HBI scores, indicating the potential of confounding relations among multiple measured and unmeasured environmental characteristics. 


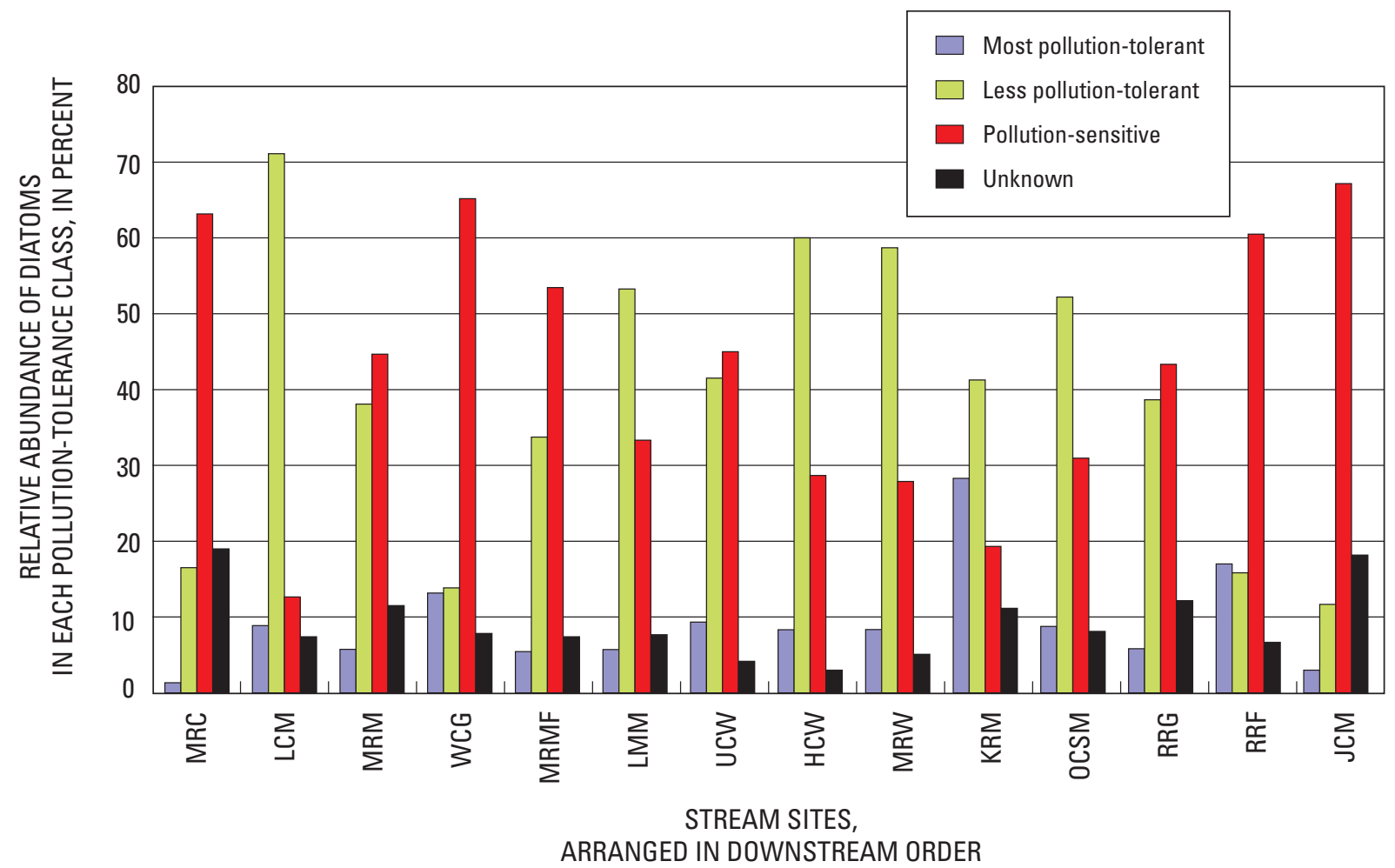

Figure 64. Percentage of diatoms in pollution-tolerance classes in the Milwaukee Metropolitan Sewerage District planning area, Wis. Site abbreviations listed in table 1.

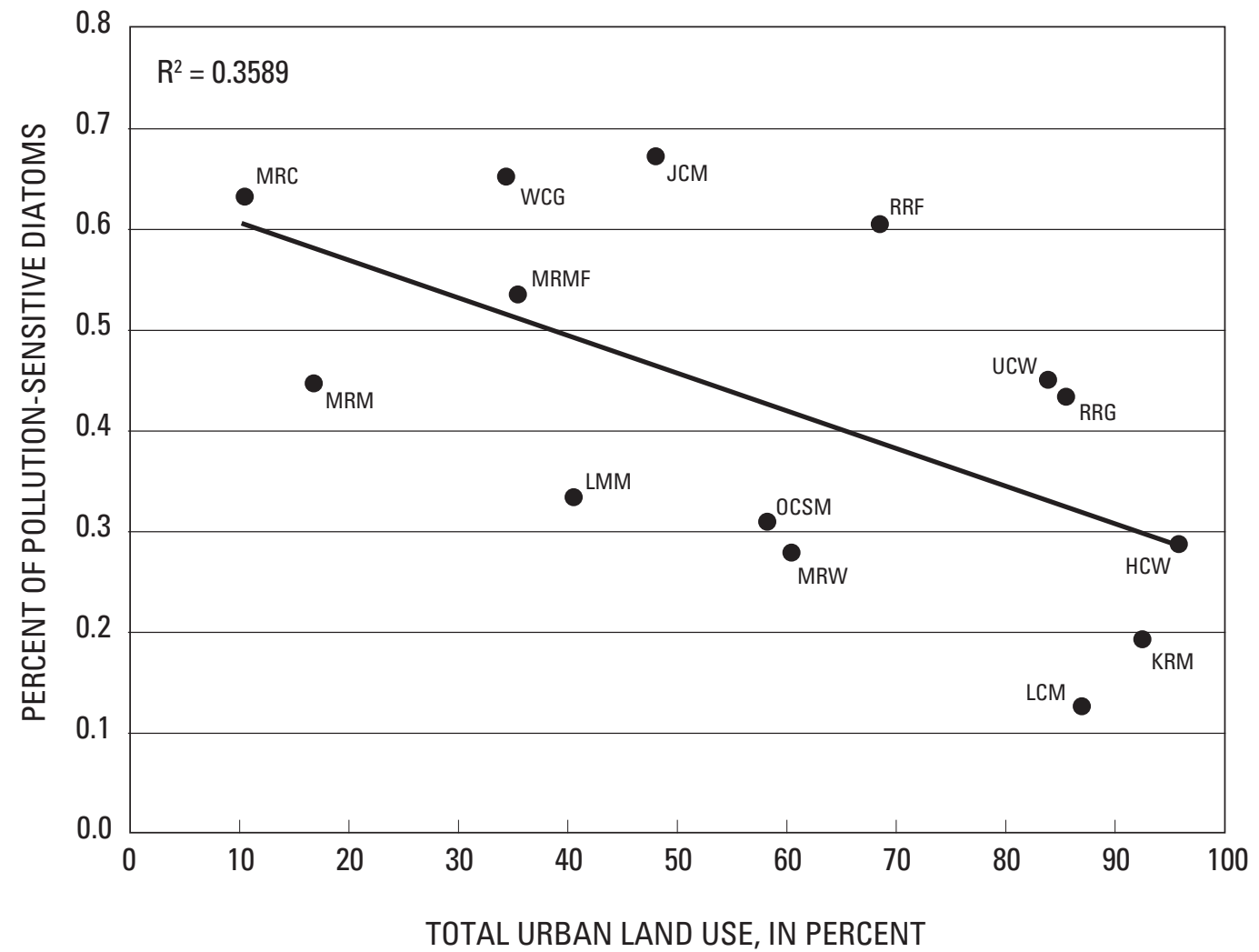

Figure 65. Percent pollution-sensitive diatoms plotted against percent urban land use in site drainage basins for 15 stream sites in the Milwaukee Metropolitan Sewerage District planning area, Wis. Site abbreviations listed in table 1. 


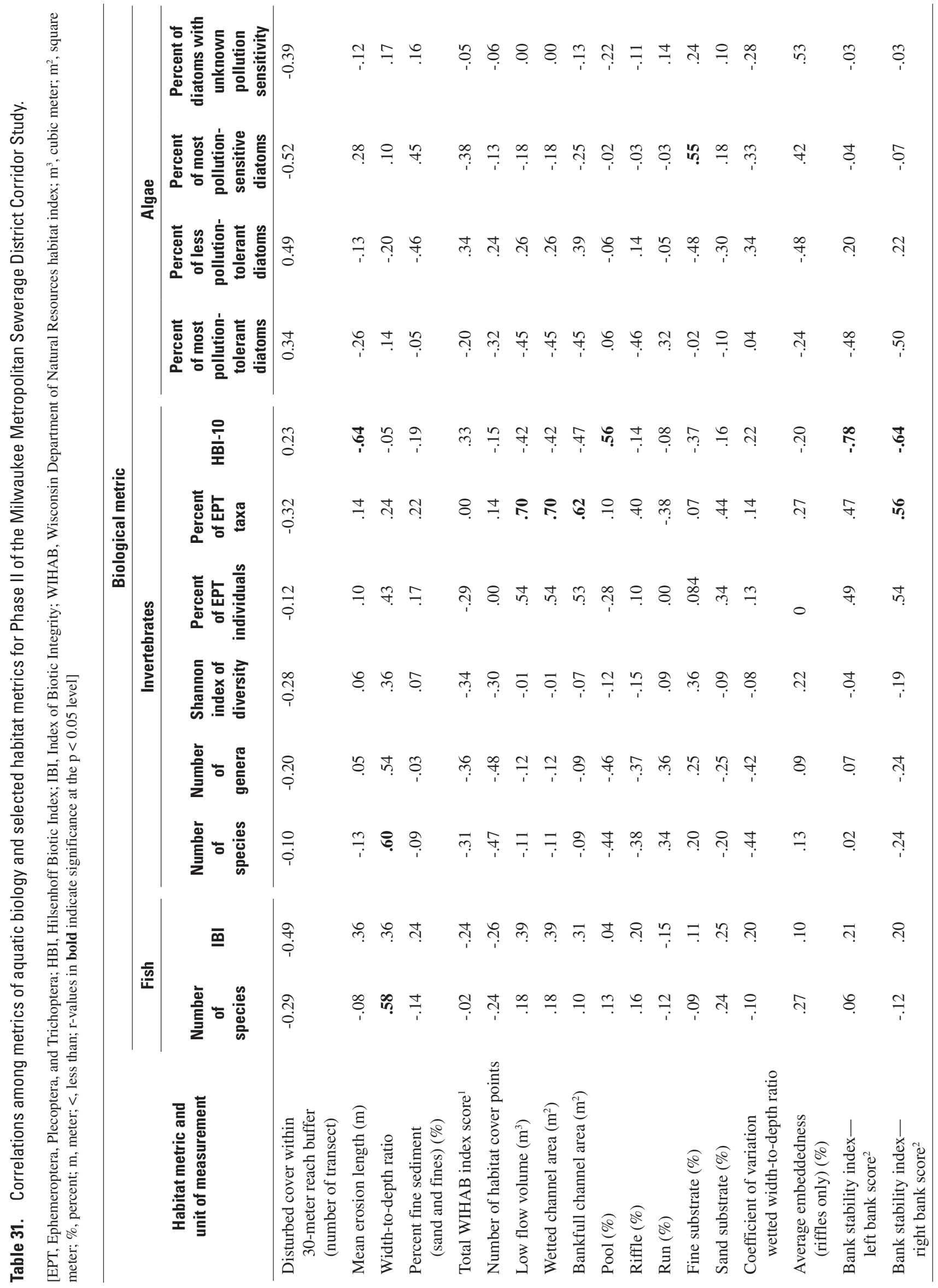




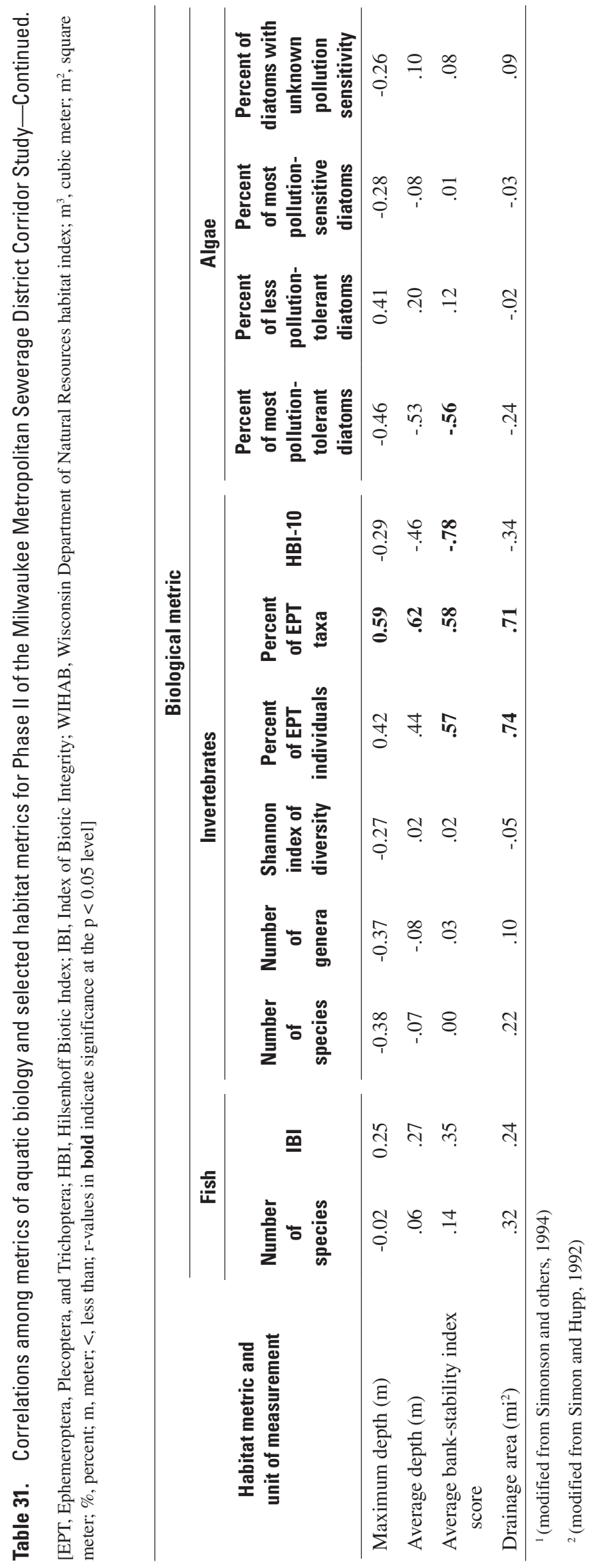




\section{Relations between Stream Biological Metrics, Site Characteristics, and Water-Quality Data}

Data for selected biological metrics were used to divide the 14 wadeable stream sites into four groups (table 32) to investigate relations between bioassessment data and site characteristic and water-quality data. Metrics from each trophic level (algae, benthic invertebrates, and fish) were selected based on their known high sensitivities to water quality; metrics were selected (either alone or in unison with others) to yield the most complete picture of water quality at each trophic level. To avoid potential bias toward any one metric or trophic level, data were standardized (ranked, lowest number indicating best water quality) and summarized at each trophic level, and the average of these ranks across trophic levels yielded aggregate bioassessment rankings. Sites were then divided into four groups based on the quartile ranges of the aggregate rankings. For the remainder of this discussion, sites will be referred to in terms of their quartile number: quartile 1 contained sites where bioassessment data indicated the least-degraded water quality among those sampled, and quartile 4 contained sites that indicated the most-degraded water quality. Quartiles contained the following stream sites:

- Quartile 1: Milwaukee River near Cedarburg, Milwaukee River at Milwaukee, Jewel Creek, and Menomonee River at Menomonee Falls

- Quartile 2: Willow Creek, Root River near Franklin, and Root River at Grange Avenue

- Quartile 3: Menomonee River at Wauwatosa, Oak Creek, and Little Menomonee River

- Quartile 4: Honey Creek, Underwood Creek, Lincoln Creek, and Kinnickinnic River

Aggregate bioassessment rankings, however, are averages of the three trophic-level rankings, and as such, results at individual trophic levels may vary. For example, although Root River at Grange Avenue had an aggregate ranking that placed it into quartile 2 , results for macroinvertebrate metrics alone would have placed it into quartile 4. Site characteristics (in this case, drainage area and land use) and selected water- and sediment-quality constituent results were summarized based on the four bioassessment quartiles (table 33) to determine if there were relations with the aggregate bioassessment rankings.
Biological metrics often correlate with site characteristics such as land use and drainage area, with higherquality biological communities and increased diversity as urban land use decreases and drainage area increases (Vannote and others, 1980; Wang and others, 2001; Paul and Meyer, 2001). Sites in quartile $1^{6}$ had the lowest mean percent urban land use and the largest mean drainage area, while sites in quartile 4 had the highest mean percent urban land use and the smallest mean drainage area (table 33). Though mean site characteristics for quartiles 2 and 3 did fall between these two extremes, sites in quartile 2 had generally more urban land use and smaller drainage areas than those in quartile 3.

Median chloride concentrations were lowest in quartile 1, with increasing concentrations in quartiles 2, 3, and 4. Chloride concentrations indicated a positive relation with increasing urban land use (fig. 9); in particular, increasing transportation land use across the quartiles may be responsible for increases in chloride concentration.

Nutrients, chlorophyll $a$, and suspended sediment results exhibited a wide range of relations to bioassessment quartiles. Median concentrations of total nitrogen and nitrate generally decreased from quartile 1 to quartile 4 , and may be attributed to differences in the percent of agricultural land use between the quartiles, as previous studies have shown that agricultural sites have higher concentrations of these constituents than do urban sites (Mueller and Spahr, 2006). Median concentrations of total phosphorus generally increased from quartile 1 to quartile 4 , while no particular relations were observed for median chlorophyll $a$ and suspended sediment concentrations.

Mercury constituents did not exhibit consistent relations to bioassessment quartiles. Median dissolved total mercury concentrations generally increased from quartile 1 to quartile 4 , whereas median dissolved methylmercury concentrations decreased across the quartiles. Previous studies have shown that urban sites have lower methylation (conversion of mercury to methylmercury) efficiency when compared to agricultural sites (Krabbenhoft and others, 1999). Median concentrations of particulate total and methylmercury varied across the quartiles.

\footnotetext{
${ }^{6}$ While the mean drainage area of quartile 1 is much larger than the rest of the quartiles, it should be noted that this quartile contains sites with drainage areas among the largest (Milwaukee at Milwaukee, 690 $\mathrm{mi}^{2}$ ) and the smallest (Jewel Creek, $8.16 \mathrm{mi}^{2}$ ) of those sampled.
} 
Table 32. Average trophic-level rankings and aggregate bioassessment rankings for Phase II stream sites in the Milwaukee Metropolitan Sewerage District planning area, Wis.

[IBI, Index of Biotic Integrity; EPT, Ephemeroptera, Plecoptera, and Trichoptera; HBI, Hilsenhoff Biotic Index; fill color indicates quartile of ranking (quartile 1, blue; quartile 2, light blue; quartile 3, light orange; quartile 4, orange; each column is considered independently)]

\begin{tabular}{|c|c|c|c|c|}
\hline \multirow{2}{*}{ Site } & \multicolumn{3}{|c|}{ Average trophic-level ranking } & \multirow{2}{*}{$\begin{array}{c}\text { Aggregate } \\
\text { bioassesment } \\
\text { ranking }\end{array}$} \\
\hline & Fish $^{1}$ & Invertebrates $^{2}$ & Algae $^{3}$ & \\
\hline & & & & Quartile 1 \\
\hline Milwaukee River near Cedarburg & 1.00 & 1.33 & 2.00 & 1.44 \\
\hline Milwaukee River at Milwaukee & 2.00 & 2.67 & 6.00 & 3.56 \\
\hline Jewel Creek at Muskego & 5.00 & 6.00 & 1.50 & 4.17 \\
\hline \multirow[t]{2}{*}{ Menomonee River at Menomonee Falls } & 3.00 & 7.33 & 4.00 & 4.78 \\
\hline & & & & Quartile 2 \\
\hline Willow Creek at Maple Road near Germantown & 4.00 & 6.17 & 7.00 & 5.72 \\
\hline Root River near Franklin & 6.00 & 6.67 & 8.50 & 7.06 \\
\hline \multirow[t]{2}{*}{ Root River at Grange Avenue at Greenfield } & 7.50 & 11.00 & 7.00 & 8.50 \\
\hline & & & & Quartile 3 \\
\hline Menomonee River at Wauwatosa & 7.50 & 8.33 & 10.00 & 8.61 \\
\hline Oak Creek at South Milwaukee & 9.50 & 7.33 & 9.50 & 8.78 \\
\hline \multirow[t]{2}{*}{ Little Menomonee River at Milwaukee } & 13.00 & 8.33 & 6.50 & 9.28 \\
\hline & & & & Quartile 4 \\
\hline Honey Creek at Wauwatosa & 11.00 & 8.17 & 9.00 & 9.39 \\
\hline Underwood Creek at Wauwatosa & 9.50 & 10.33 & 8.50 & 9.44 \\
\hline Lincoln Creek at 47th Street at Milwaukee & 13.00 & 9.67 & 12.00 & 11.56 \\
\hline Kinnickinnic River at S. 11th Street at Milwaukee & 13.00 & 11.67 & 13.50 & 12.72 \\
\hline
\end{tabular}

${ }^{1}$ Averaged trophic-level rankings included only fish IBI scores.

${ }^{2}$ Averaged trophic-level rankings included Shannon index of diversity scores, percent of EPT taxa, and HBI-10 scores.

${ }^{3}$ Averaged trophic-level rankings included percent of most-sensitive diatoms and percent of sensitive diatoms. 
Table 33. Summarized results of Phase II constituents, grouped by aggregate bioassessment ranking in the Milwaukee Metropolitan Sewerage District planning area, Wis.

[mg/L, milligram per liter; $\mu \mathrm{g} / \mathrm{L}$, microgram per liter; col/100 mL, colonies per 100 milliliters; MPN/100 mL, most probable number per 100 milliliters; plaques/100mL, plaques per 100 milliliters; DF, detection frequency; mg/kg, milligram per kilogram; $\mu \mathrm{g} / \mathrm{g}$, microgram per gram; PCB, polychlorinated biphenyl; PAH, polycyclic aromatic hydrocarbon; EDC, known or suspected endocrine-disruptor; <, less than. Values in parentheses indicate the range of possible median concentrations for constituents where the median is an average calculated from a concentration above and a concentration below the reporting level. Fill color indicates relative value of each constituent and increases in value from blue, to light blue, to light orange, to orange; where there is only one mid-range value (that is, where there is a single value, or two identical values), fill color is determined by the difference from the minimum and maximum values: light blue if closest to minimum value and light orange if closest to maximum value.]

\begin{tabular}{|c|c|c|c|c|c|c|}
\hline \multirow[b]{2}{*}{ Constituent } & \multirow[b]{2}{*}{ Unit } & \multirow[b]{2}{*}{$\begin{array}{l}\text { Measure } \\
\text { of center }\end{array}$} & \multicolumn{4}{|c|}{$\begin{array}{l}\text { Summarized results grouped by } \\
\text { aggregate bioassessment ranking }\end{array}$} \\
\hline & & & $\begin{array}{l}\text { Quartile } 1 \\
\text { sites }\end{array}$ & $\begin{array}{l}\text { Quartile } 2 \\
\text { sites }\end{array}$ & $\begin{array}{l}\text { Quartile } 3 \\
\text { sites }\end{array}$ & $\begin{array}{c}\text { Quartile } 4 \\
\text { sites }\end{array}$ \\
\hline \multicolumn{7}{|c|}{ Site characteristics } \\
\hline Drainage area & square miles & mean & 335 & 23.4 & 55.9 & 14.2 \\
\hline Agricultural & percent & mean & 42 & 16 & 23 & $<1$ \\
\hline Natural areas & percent & mean & 31 & 21 & 23 & 10 \\
\hline Urban & percent & mean & 28 & 63 & 53 & 90 \\
\hline Transportation & percent & mean & 8 & 18 & 18 & 30 \\
\hline Industrial & percent & mean & 3 & 1 & 4 & 3 \\
\hline Commercial & percent & mean & 1 & 2 & 2 & 4 \\
\hline Residental & percent & mean & 14 & 36 & 24 & 42 \\
\hline Other urban & percent & mean & 2 & 5 & 6 & 11 \\
\hline \multicolumn{7}{|c|}{ Major lons } \\
\hline Chloride, water, filtered & $\mathrm{mg} / \mathrm{L}$ & median & 116 & 144 & 175 & 232 \\
\hline \multicolumn{7}{|c|}{ Nutrients, chlorophyll $a$, and suspended sediment } \\
\hline $\begin{array}{l}\text { Total nitrogen (nitrate }+ \text { nitrite }+ \\
\text { ammonia }+ \text { organic nitrogen), water, } \\
\text { unfiltered, analytically determined }\end{array}$ & $\mathrm{mg} / \mathrm{L}$ as nitrogen & median & 1.54 & 1.28 & 1.33 & 1.16 \\
\hline Nitrite plus nitrate, water, filtered & $\mathrm{mg} / \mathrm{L}$ as nitrogen & median & 0.780 & 0.630 & 0.530 & 0.515 \\
\hline Phosphorus, water, unfiltered & $\mathrm{mg} / \mathrm{L}$ & median & 0.105 & 0.092 & 0.116 & 0.141 \\
\hline $\begin{array}{l}\text { Chlorophyll } a \text {, water, unfiltered, } \\
\text { trichromatic method, uncorrected }\end{array}$ & $\mu \mathrm{g} / \mathrm{L}$ & median & 9.99 & 2.74 & 6.65 & 5.54 \\
\hline Suspended sediment concentration & $\mathrm{mg} / \mathrm{L}$ & median & 16 & 18 & 22 & 7 \\
\hline \multicolumn{7}{|c|}{ Mercury } \\
\hline $\begin{array}{l}\text { Mercury, water, filtered } \\
\text { (dissolved total mercury) }\end{array}$ & $\mathrm{ng} / \mathrm{L}$ & median & 0.98 & 0.98 & 1.48 & 1.66 \\
\hline $\begin{array}{l}\text { Mercury, suspended sediment, total } \\
\text { (particulate total mercury) }\end{array}$ & $\mathrm{ng} / \mathrm{L}$ & median & 1.34 & 1.28 & 3.08 & 1.21 \\
\hline $\begin{array}{l}\text { Methylmercury, water, filtered, recoverable } \\
\text { (dissolved methylmercury) }\end{array}$ & $\mathrm{ng} / \mathrm{L}$ & median & 0.10 & 0.08 & 0.07 & 0.06 \\
\hline $\begin{array}{l}\text { Methylmercury, suspended sediment, total } \\
\text { (particulate methylmercury) }\end{array}$ & $\mathrm{ng} / \mathrm{L}$ & median & 0.056 & 0.038 & 0.069 & 0.044 \\
\hline \multicolumn{7}{|c|}{ Indicator organisms } \\
\hline Fecal coliform & $\mathrm{col} / 100 \mathrm{~mL}$ & median & 180 & 420 & 580 & 780 \\
\hline Escherichia coli & MPN/100 mL & median & 180 & 460 & 690 & 1,000 \\
\hline Coliphage & plaques/100 mL & median & 1 & 1 & 9 & 16 \\
\hline Coliphage, groups II and III & DF & median & 6 & 8 & 17 & 25 \\
\hline
\end{tabular}


Table 33. Summarized results of Phase II constituents, grouped by aggregate bioassessment ranking in the Milwaukee Metropolitan Sewerage District planning area, Wis.-Continued.

$[\mathrm{mg} / \mathrm{L}$, milligram per liter; $\mu \mathrm{g} / \mathrm{L}$, microgram per liter; col/100 mL, colonies per 100 milliliters; MPN/100 mL, most probable number per 100 milliliters; plaques $/ 100 \mathrm{~mL}$, plaques per 100 milliliters; DF, detection frequency; $\mathrm{mg} / \mathrm{kg}$, milligram per kilogram; $\mu \mathrm{g} / \mathrm{g}$, microgram per gram; PCB, polychlorinated biphenyl; PAH, polycyclic aromatic hydrocarbon; EDC, known or suspected endocrine-disruptor; <, less than. Values in parentheses indicate the range of possible median concentrations for constituents where the median is an average calculated from a concentration above and a concentration below the reporting level. Fill color indicates relative value of each constituent and increases in value from blue, to light blue, to light orange, to orange; where there is only one mid-range value (that is, where there is a single value, or two identical values), fill color is determined by the difference from the minimum and maximum values: light blue if closest to minimum value and light orange if closest to maximum value.]

\begin{tabular}{|c|c|c|c|c|c|c|}
\hline \multirow[b]{2}{*}{ Constituent } & \multirow[b]{2}{*}{ Unit } & \multirow[b]{2}{*}{$\begin{array}{l}\text { Measure } \\
\text { of center }\end{array}$} & \multicolumn{4}{|c|}{$\begin{array}{l}\text { Summarized results grouped by } \\
\text { aggregate bioassessment ranking }\end{array}$} \\
\hline & & & $\begin{array}{l}\text { Quartile } 1 \\
\text { sites }\end{array}$ & $\begin{array}{l}\text { Quartile } 2 \\
\text { sites }\end{array}$ & $\begin{array}{l}\text { Quartile } 3 \\
\text { sites }\end{array}$ & $\begin{array}{l}\text { Quartile } 4 \\
\text { sites }\end{array}$ \\
\hline \multicolumn{7}{|c|}{ Pathogenic organisms } \\
\hline Salmonella & DF & median & 19 & 44 & 44 & 23 \\
\hline Cryptosporidium & DF & median & 42 & 42 & 50 & 42 \\
\hline Giardia & DF & median & 27 & 36 & 28 & 19 \\
\hline Escherichia coli $\mathrm{O} 157: \mathrm{H} 8$ & DF & median & 6 & 3 & 0 & 2 \\
\hline \multicolumn{7}{|c|}{ Bed sediment } \\
\hline Arsenic in sediment & $\mathrm{mg} / \mathrm{kg}$ & median & $(3.0-3.5)$ & $(4.0-4.5)$ & $<1.0$ & 5.5 \\
\hline Cadmium in sediment & $\mathrm{mg} / \mathrm{kg}$ & median & $<0.100$ & $(0.45-0.50)$ & $<0.100$ & $<0.100$ \\
\hline Chromium in sediment & $\mathrm{mg} / \mathrm{kg}$ & median & 15 & 12 & 15 & 19 \\
\hline Copper in sediment & $\mathrm{mg} / \mathrm{kg}$ & median & 20 & 22 & 16 & 38 \\
\hline Lead in sediment & $\mathrm{mg} / \mathrm{kg}$ & median & 26 & 16 & 22 & 39 \\
\hline Mercury in sediment & $\mathrm{mg} / \mathrm{kg}$ & median & 0.05 & 0.04 & 0.03 & 0.05 \\
\hline Nickel in sediment & $\mathrm{mg} / \mathrm{kg}$ & median & 11 & 12 & 6.5 & 11 \\
\hline Total phosphorus in sediment & $\mathrm{mg} / \mathrm{kg}$ & median & 710 & 690 & 300 & 1,100 \\
\hline Zinc in sediment & $\mathrm{mg} / \mathrm{kg}$ & median & 80 & 79 & 66 & 200 \\
\hline Total PCBs in sediment & $\mu \mathrm{g} / \mathrm{g}$ & median & 0.29 & $<0.02$ & 0.04 & 0.03 \\
\hline \multicolumn{7}{|c|}{ Wastewater compounds } \\
\hline Antimicrobial disinfectants & DF & median & 4 & 0 & 3 & 6 \\
\hline Antioxidants & DF & median & 0 & 0 & 0 & 25 \\
\hline Detergent metabolites & $\mathrm{DF}$ & median & 15 & 19 & 33 & 38 \\
\hline Dyes and pigments & DF & median & 38 & 67 & 86 & 96 \\
\hline Fire retardants & $\mathrm{DF}$ & median & 34 & 56 & 89 & 96 \\
\hline Flavors and fragrances & DF & median & 30 & 36 & 53 & 77 \\
\hline Fuels & DF & median & 6 & 8 & 6 & 19 \\
\hline Herbicides & DF & median & 38 & 39 & 42 & 46 \\
\hline Human drugs (nonprescription) & DF & median & 53 & 64 & 97 & 96 \\
\hline Insecticides & DF & median & 66 & 72 & 92 & 98 \\
\hline PAHs & DF & median & 32 & 53 & 81 & 83 \\
\hline Plasticizers & DF & median & 34 & 42 & 61 & 79 \\
\hline Sterols & DF & median & 6 & 11 & 11 & 15 \\
\hline Solvents & DF & median & 9 & 8 & 14 & 17 \\
\hline Miscellaneous & DF & median & 11 & 8 & 11 & 15 \\
\hline EDCs & $\mathrm{DF}$ & median & 55 & 64 & 75 & 83 \\
\hline
\end{tabular}


Median results for all indicator organisms increased from quartile 1 to quartile 4 . The increasing detection frequencies (DFs) of the coliphage serogroups II and III across the quartiles indicated probable increases in human sources of fecal contamination. Percent urban land also generally increased from quartiles 1 to 4 .

In contrast with indicator organisms, DFs for pathogenic organisms did not indicate a particular increase or decrease across quartiles.

DFs of wastewater compound (WWC) constituent classes and known or suspected endocrine-disrupting compounds (EDCs) generally increased across the quartiles, though there were a few exceptions. For example, the DFs for fuels varied across the first three quartiles, but all had similar results and were less than half the DF observed for quartile 4. DFs for nonprescription human drugs in quartiles 1 and 2 were similar and lower than DFs in quartiles 3 and 4, which were higher and also similar to each other. Although median bed sediment constituent concentrations did not show consistent relations across the quartiles, quartile medians observed for three constituents (zinc, total polychlorinated biphenyls (PCBs), and total phosphorus) contained one quartile with notably higher concentrations than the remaining three quartiles. Two of these constituents (zinc and total phosphorus) had the highest median concentrations in quartile 4. Previous studies have shown that zinc concentrations in street refuse are highest in areas of transportation land use; therefore, the higher concentrations observed in quartile 4 may be attributable to the higher proportion of transportation land use in this quartile (Novotny and Chesters, 1981). Other studies have found that the highest proportion of total phosphorus in urban land uses comes from lawns and streets; the higher proportion of residential and transportation land uses in quartile 4 may be responsible for these higher concentrations (Waschbusch and others, 1999). In contrast, the highest median PCB concentration was observed in quartile 1; this may be due to contamination from the Cedar Creek Superfund alternative site which is upstream of two of the four sites (Milwaukee River near Cedarburg and Milwaukee River at Milwaukee) included in that quartile. Fish-tissue samples collected from the Milwaukee River at Milwaukee also had detections of PCBs (fish-tissue samples were not collected at Milwaukee River near Cedarburg). PCB contamination at these sites has been well-documented in previous studies (Scudder and others, 1997; Steuer and others, 1999; Wisconsin Department of Natural Resources, 2006).
The imperfect relation of biological metrics to site characteristics and water-quality data is likely indicative of additional influences on the quality of biological communities. A number of influences on biological communities may assist in explaining these differences: stream flashiness (by minimizing macroinvertebrates and algae colonization); localized intermittent pollution; and toxicity from unidentified constituents. In addition, reach selection shows inherent bias toward sites where biota is available for sampling, which may not accurately represent the overall quality of the stream. Since neither biological metrics nor water-quality data provided a complete description of stream quality, the Phase II assessment of streams was strengthened by the use of both approaches to establish a holistic baseline assessment of stream quality. 


\section{Potential Areas for Data Collection in Phase III}

Given the emphasis on the spatial and temporal distribution of water-quality characteristics in Phase II, future efforts could be more hypothesis-driven, seeking to answer specific questions that have yet to be addressed in the MMSD planning area. For example, what are the long-term effects of changing water quality on biotic communities? What is the relative magnitude and contribution of waterborne pathogens from major sources on an annual basis? Phase II results indicated that bioassessment of the streams was a useful tool for assessing overall stream conditions, particularly in combination with the water quality results. Continued biological data collection would enhance understanding of overall water quality and give a long-term picture of stream conditions in the MMSD planning area. Although microbiological data collection during Phase II was, in part, to augment historical datacollection efforts, results suggested the utility of focused studies such as direct testing for pathogenic viruses, as well as studies to determine sources of Cryptosporidium and Giardia within the urban landscape. These microbiological investigations could be designed to (1) define the relative magnitude and contribution of waterborne human pathogenic viruses from major sources on an annual basis, and (2) define the relative loading of Cryptosporidium and Giardia from different land uses and source areas within the urban landscape. Determinations of toxicity levels in the water column, sediment, and SPMDs of urban streams could be integrated into further studies of the relative concentrations and loads of WWCs in the water column, bed sediment, biota, and post-treatment wastewater mixed with lake water. Performed with an integrated approach, these investigations could provide MMSD with a better understanding of the changes and challenges in the MMSD planning area.

\section{Summary}

From February 2004 through September 2005, USGS personnel, in cooperation with MMSD, were involved in an extensive data-collection effort as part of Phase II of the MMSD Corridor Study. The purpose of this data-collection effort was to address spatial, temporal, and technological gaps identified in the Phase I data analysis. This effort included the addition of harbor sites in Phase II, resulting in data collection at 15 stream and 6 harbor sites within the MMSD planning area. Data gathering included the collection of stream-discharge data for selected streams, the sampling and analysis for over 220 water-quality properties and constituents, and collection of additional suspended sediment, total phosphorus, and chloride data for computation of loads, yields, and volumetrically weighted concentrations at 4 sites. Bioassessment during autumn 2004 included gathering biologic-community data and stream-habitat data at wadeable Phase II stream sites.

\section{Summary of Relations between Biological Metrics, Site Characteristics, and Water- Quality Data}

Data for selected biological metrics were used to divide the 14 wadeable stream sites into four groups to investigate relations between bioassessment data and site characteristic and water-quality data. Aggregate bioassessment rankings of Phase II data were used to divide the sites into four quartiles reflecting relative water quality. Quartile 1 contained sites where bioassessment data indicated the least-degraded water quality among those sampled, and quartile 4 contained sites that indicated the most-degraded water quality. Quartiles contained the following stream sites:

- Quartile 1: Milwaukee River near Cedarburg, Milwaukee River at Milwaukee, Jewel Creek, and Menomonee River at Menomonee Falls

- Quartile 2: Willow Creek, Root River near Franklin, and Root River at Grange Avenue

- Quartile 3: Menomonee River at Wauwatosa, Oak Creek, and Little Menomonee River

- Quartile 4: Honey Creek, Underwood Creek, Lincoln Creek, and Kinnickinnic River 
Site characteristics (in this case, drainage area and land use) and selected water- and sediment-quality constituent results were summarized based on the four bioassessment quartiles to determine if there were relations with the aggregate bioassessment rankings. In general, sites having the largest drainage basins with lowest proportion of urban land use were in quartile 1 , and the smallest drainage basins with highest proportion of urban land use were in quartile 4. Major ions, indicator organisms, and wastewater compounds generally had the lowest overall results in quartile 1 , and highest overall results in quartile 4 . Results for other constituent types (nutrients, mercury, pathogenic organisms, and bed sediment) indicated mixed results, with results for some constituents decreasing from quartile 1 to quartile 4 . Since neither biological metrics nor water-quality data provided a complete description of stream quality, the Phase II assessment of streams was strengthened by the use of both approaches to establish a holistic baseline assessment of stream quality.

\section{Findings for Harbor Sites and the Milwaukee River at Mouth at Milwaukee Site}

Harbor results from Phase II data collection indicated that most of the water-quality constituents highlighted in this report were also detected in the harbor. In the inner harbor, approximately half of the constituents highlighted had similar results when compared to results from stream sites; remaining constituents had results that were generally lower than those from stream sites. In the outer harbor, most constituents highlighted had lower results when compared to results from stream sites and inner-harbor sites.

Phase II findings indicated that 13 of the 15 wastewater compound (WWC) classes were present in the Milwaukee Harbor. In the inner harbor, results for seven WWC classes indicated DFs similar to those in stream samples: detergent metabolites, fire retardants, flavors and fragrances, herbicides, human drugs (nonprescription), insecticides, and miscellaneous. The antimicrobial disinfectant and antioxidant classes were not detected in the inner harbor. In the outer harbor, results for two WWC classes indicated DFs similar to those in stream samples: herbicides and miscellaneous. Eight classes were not detected in the outer harbor: antimicrobial disinfectants, antioxidants, detergent metabolites, dyes and pigments, fuel, plasticizers, solvents, and sterols.
The Milwaukee River at Mouth site integrates flow from multiple streams and is affected by seiches from Lake Michigan. Median results for certain water-quality constituents at this site were similar to those for innerharbor samples, and median results for other constituents were more like those for stream samples. The median chloride concentration at Milwaukee River at Mouth was less than half than that observed at most stream sites, and was similar to median concentrations observed at harbor sites. Median concentrations for nutrients were similar to those for stream sites. The Milwaukee River at Mouth site had the lowest median concentrations of all stream sites for dissolved mercury and dissolved and particulate methylmercury (similar to harbor samples), but median concentrations of particulate mercury were similar to samples from the other stream sites. Median concentrations of indicator organisms (fecal coliform, E. coli, and coliphage) were lower than those observed at stream sites, but were higher than those observed in harbor samples. DFs of coliphage groups II and III indicated that, of the coliphage detected, the proportion of probable human sources was more similar to stream sites than harbor sites. With the exception of E. coli $\mathrm{O} 157: \mathrm{H} 7$, pathogen DFs were similar to those observed in stream samples. DFs of WWCs were similar to those observed at stream sites. Concentrations of trace elements and PCBs in bed sediment at Milwaukee at Mouth were among the highest observed at Phase II stream sites.

\section{Phase I-Phase II Comparisons}

General comparisons between Phase I and Phase II median concentrations were made where data were available for both phases and were sufficient to discern an overall pattern. Phase I median concentrations were calculated from available data; depending on the constituent, the amount of data ranged from a small dataset with only a few results to a large dataset with numerous results. Comparisons could not be made for a number of Phase II constituents (for example, the WWCs), as technology to analyze for many of these compounds has only recently been developed. For many of the constituents for which comparable data were available for Phase I and Phase II, notable differences were evident (appendix 5). All comparisons between Phase I and Phase II were for manually collected samples; automatically collected samples used for Phase II loads determinations had no Phase I counterparts available for comparison. 
Median chloride concentrations generally increased between Phase I and Phase II, likely because winter sampling and event sampling were included as part of Phase II. This finding indicated that winter contributions of chloride to streams may be substantial. Increased chloride concentrations typically occur in winter when road salts were used as deicers on smaller snowfall events (typically 1 to 2 inches) and road salts are used to clear roads and parking lots. Meltwater from deicing activities of this kind produce small volumes of runoff with high concentrations of chloride. This type of runoff has the most effect on urban streams where the proportion of runoff is high due to the concentration of impervious surfaces, and where roads are prevalent and frequently deiced. Phase II stream sites with median chloride concentrations above the USEPA national chronic freshwater-quality criterion all had drainage basins with over 80 percent urban land use.

Nutrients, chlorophyll $a$, and suspended sediment concentrations indicated varying results from Phase I to Phase II. Total nitrogen and suspended sediment concentrations decreased or indicated no notable difference. Nitrate, total phosphorus, and chlorophyll $a$ concentrations increased or indicated no notable difference from Phase I to Phase II.

Indicator organisms, fecal coliform, and E. coli comparisons also indicated varying results from Phase I to Phase II. Fecal coliform concentrations were generally decreasing. E. coli concentrations indicated no notable difference, but this may be due to the limited data set available for Phase I.

Although bed-sediment data for Phase I was limited, changes were still observed. Median concentrations of most trace elements (cadmium, chromium, copper, lead, mercury, nickel, and zinc) in bed sediment decreased from Phase I to Phase II; however, arsenic concentrations increased. PCB concentrations in bed sediment indicated no notable difference once the increased analytical sensitivity of Phase II analyses had been considered.

PCB data in sediment and fish tissue were available for comparison at three sites between Phase I and Phase II, because Phase II fish tissue samples were only collected at Milwaukee River at Milwaukee, Menomonee River at Wauwatosa, and Root River near Franklin. Although direct comparisons between the Lower Milwaukee River subwatershed and the three Milwaukee River Phase II sites were generally avoided, contamination of this subwatershed with synthetic organic contaminants (especially PCBs) is well documented and was discussed in general terms using data from the Milwaukee River at Milwaukee site.
The Milwaukee River continued to have PCB detections in fish tissue, which could be due to contamination from the upstream Cedar Creek Superfund alternative site. At the Menomonee River at Wauwatosa site, PCBs were detected in bed sediment in both Phase I and Phase II; PCBs were not detected in fish tissue in Phase I but were detected in Phase II, which could imply that PCBs persisting in bed sediments are now moving up into biological systems. At the Root River near Franklin site, no PCBs were detected in bed sediment during Phase II. No data were available for Phase I. There were also no PCB detections in fish tissue in either Phase I or Phase II at the Root River near Franklin site. Upstream, at the Root River at Grange Avenue site, PCBs were detected in bed sediment during Phase II.

Fish-tissue data also were analyzed for historically used pesticides. Pesticide detections in fish tissue were observed at the Milwaukee River at Milwaukee site during Phase I; however concentrations observed during Phase II were below the Phase I reporting level. Although not detected in fish-tissue samples at Menomonee River at Wauwatosa during Phase I, historically used pesticides were observed in the samples collected during Phase II at concentrations above the Phase I reporting level. Root River near Franklin had no pesticide detections in fish tissue in Phase I or Phase II.

Bioassessments of streams indicated varying results when Phase I and Phase II data were compared. EPT taxa representation at most sites remained constant or improved from Phase I to Phase II; declines in EPT taxa representation were observed at Oak Creek and Root River near Franklin. In addition, the majority of Phase II HBI-10 scores remained constant or improved when compared to Phase I water-quality ratings; increases in HBI-10 ratings (from fairly poor to fair) were observed at Oak Creek and Root River at Grange Avenue. Fish IBI data had fewer sites available for comparison; however, where available, Phase II biotic integrity ratings at compared sites either remained constant or worsened when compared with Phase I. Although results for macroinvertebrate assessments were generally inconsistent with the fish IBI data, changes in water quality are generally reflected at the lower trophic levels first; therefore, this inconsistency may be an indication of improving water quality in these urban streams. 


\section{References}

Agency for Toxic Substances and Disease Registry, 1999, ToxFAQs for isophorone: Atlanta, Ga., U.S. Department of Health and Human Services, Public Health Service, accessed December 28, 2006, at http://www.atsdr.cdc. gov/tfacts138.html

Agency for Toxic Substances and Disease Registry, 2006, ToxFAQs for cresol: Atlanta, Ga., U.S. Department of Health and Human Services, Public Health Service, accessed December 28, 2006, at http://www.atsdr.cdc. gov/tfacts34.html

AZUR Environmental, 1998, Microtox acute toxicity test, in AZUR Environmental, Microtox test manual: Newark, Del., Strategic Diagnostics Inc., accessed December 28, 2006, at http://www.azurenv.com/mtox.htm

Baird and Associates, 1997, Milwaukee River PCB mass balance project final report: Madison, Wis., Baird and Associates, $276 \mathrm{p}$.

Bahls, L.L., 1993, Periphyton bioassessment methods for Montana streams (revised): Helena, Mont., Montana Department of Health and Environmental Sciences, Water Quality Bureau, 69 p.

Capel, P.D., Spexet, A.H., and Larson, S.J., 1999, Occurrence and behavior of the herbicide Prometon in the hydrologic system: Environmental Science and Technology, v. 33 , no. 5 , p. 674-680.

Carlson, R.E., 1977, A trophic state index for lakes: Limnology and Oceanography, v. 22, no. 2, p. 361-369.

Chang, J.C., Taylor, P.B., and Leach, F.R., 1981, Use of the Microtox assay system for environmental samples: Bulletin of Environmental Contamination and Toxicology, v. 26, no. 1, p. 150-156.

Combs, S.M., and Peters, J.B., [n.d.], Wisconsin soil test summary, 1995-1999, phosphorus map: University of Wisconsin-Madison, Department of Soil Science, Soil \& Plant Analysis Lab, accessed January 18, 2007, at http://uwlab.soils.wisc.edu/madison/

Corsi, S. R., Graczyk, D.J., Owens, D.W., and Bannerman, R.T., 1997, Unit-area loads of suspended sediment, suspended solids and total phosphorus from small watersheds in Wisconsin: U.S. Geological Survey Fact Sheet 1997-195, 4 p.

Corsi, S.R., Zitomer, D.H., Field, J.A., and Cancilla, D.A., 2003, Nonylphenol ethoxylates and other additives in aircraft deicers, antiicers, and waters receiving airport runoff: Environmental Science \& Technology, v. 37, no. 18 , p. $4031-4037$
Daughton, C.G., and Ternes, T.A., 1999, Pharmaceuticals and personal care products in the environment: agents of subtle change?: Human Health Perspectives, v. 107, supl. 6, p. 907-938.

Dufour, A.P., 1984, Health effects criteria for fresh recreational waters: U.S. Environmental Protection Agency, Office of Research and Development, EPA-600/1-84004, $33 \mathrm{p}$.

Fitzpatrick, F.A., White, I.R., D'Arconte, P.J., Meador, M.R., Maupin, M.A., and Gurtz, M.E., 1998, Revised methods for characterizing stream habitat in the National Water-Quality Assessment Program: U.S. Geological Survey Water-Resources Investigations Report 98-4052, $67 \mathrm{p}$.

Gilliom, R.J., Barbash, J.E., Crawford, C.G., Hamilton, P.A., Martin, J.D., Nakagaki, N., Nowell, L.H., Scott, J.C., Stackelberg, P.E., Theilin, G.P., and Wolock, D.M., 2006, The quality of our Nation's waters-pesticides in the Nation's streams and ground water, 1992-2001: U.S. Geological Survey Circular 1291, 172 p.

Goldman, C.R., and Horne. A.J., 1983, Limnology: New York, McGraw-Hill, 464 p.

Graczyk, D.J., and Vanden Brook, J.D., 1997, Herbicides in the Pecatonica and Yahara River in Southwestern Wisconsin, May 1996-July 1996: U.S. Geological Survey Fact Sheet 175-197, 4 p.

Graczyk, D.J., Vanden Brook, J.D., and Rheineck, B.D., 1999, Herbicides in the Pecatonica, Trempealeau, and Yahara River in Wisconsin, May 1997-July 1998: U.S. Geological Survey Fact Sheet 167-99, 6 p.

Hilsenhoff, W.L., 1987, An improved biotic index of organic stream pollution: Great Lakes Entomologist, v. 20 , no. 1, p. 31-40.

Hilsenhoff, W.L., 1998, A modification of the biotic index of organic stream pollution to remedy problems and permit its use throughout the year: Great Lakes Entomologist, v. 31, no. 1, p. 1-12.

Iman, R.L., and Conover, W.J., 1983, A modern approach to statistics: New York, John Wiley, 497 p.

Kaiser, Jocelyn, 2000, Endocrine disrupters: panel cautiously confirms low-dose effects: Science, v. 290, no. 5492, p. 695-697.

Karr, J.R., 1981, Assessment of biotic integrity using fish community: Fisheries, vol. 6, p. 21-27.

Karr, J.R., Fausch, K.D., Angermeier, P.L., Yant, P.R., and Schlosser, I.J., 1986, Assessing biological integrity in running waters: a method and its rationale: Illinois Natural History Survey Special Publication 5, 28 p. 
Kingsbury, J.A., Hopple, J.A., Delzer, G.C., 2006, Review of quality-control and environmental data for wastewater effluent compounds collected for the NAWQA Source Water-Quality Assessment: U.S. Geological Survey, accessed January 3, 2007 at http://wwwdsd.cr.usgs. gov/nawqa/vocns/swqa/SWQA_1433_QC_2004.pdf

Kolpin, D.W., Furlong, E.T., Meyer, M.T., Thurman, E.M., Zaugg, S.D., Barber, L.B., and Buxton, H.T., 2002, Pharmaceuticals, hormones, and other organic wastewater contaminants in U.S. streams, 1999-2000: a national reconnaissance: Environmental Science \& Technology, v. 36 , no. 6 , p. 1202-1211.

Krabbenhoft, D.P., Wiener, J.G., Brumbaugh, W.G., Olson, M.L., DeWild, J.F., and Sabin, T.J., 1999, A national pilot study of mercury contamination of aquatic ecosystems along multiple gradients, in Morganwalp, D.W., and Buxton, H.T., eds., U.S. Geological Survey Toxic Substances Hydrology Program-proceedings of the technical meeting, Charleston, S.C., March 8-12, 1999-volume 2 of 3, Contamination of hydrologic systems and related ecosystems: U.S. Geological Survey Water-Resources Investigations Report 99-4018B, p. $147-160$.

Kunze, A.E., and Sroka, B.N., 2004, Effects of highway deicing chemicals on shallow unconsolidated aquifers in Ohio-final report: U.S. Geological Survey Scientific Investigations Report 2004-5150, 187 p.

Lange-Bertalot, H., 1979, Pollution tolerance of diatoms as a criterion for water quality estimation: Nova Hedwigia, v. 64 , p. $285-304$.

Lee, K.E., Barber, L.B., Furlong, E.T., Cahill, J.D., Kolpin, D.W., Meyer, M.T., and Zaugg, S.D., 2004, Presence and distribution of organic wastewater compounds in wastewater, surface, ground, and drinking waters, Minnesota, 2000-02: U.S. Geological Survey Scientific Investigations Report 2004-5138, 47 p.

Lyons, John, 1992, Using the index of biotic integrity (IBI) to measure environmental quality in warmwater streams of Wisconsin: St. Paul, Minn., U.S. Department of Agriculture Forest Service, North Central Forest Experiment Station, 48 p.

MacCoy, D.E., 2004, Water-quality and biological conditions in the Lower Boise River, Ada and Canyon Counties, Idaho, 1994-2002: U.S. Geological Survey Scientific Investigations Report 2004-5128, 80 p.

MacDonald, D.D., Ingersoll, C.G., and Berger, T.A., 2000, Development and evaluation of consensus-based sediment quality guidelines for freshwater ecosystems: Archives of Environmental Contamination and Toxicology, v. 39, no. 1, p. 20-31.
Mahler, B.J., Van Metre, P.C., Bashara, T.J., Wilson, J.T., and Johns, D.A., 2005. Parking lot sealcoat: an unrecognized source of urban polycyclic aromatic hydrocarbons: Environmental Science \& Technology, v. 39, no. 15 , p. $5560-5566$.

Mara, Duncan, and Horan, N.J., eds., 2003, The handbook of water and wastewater microbiology: San Diego, Calif., Academic Press, 819 p.

Mason, R.P., Fitzgerald, W.F., and Morel, F.M.M., 1994, The biogeochemical cycling of elemental mercury: anthropogenic influences: Geochimica et Cosmochimica Acta, v. 58, no. 15, p. 3191-3198.

Moulton, S.R., II, Kennen, J.G., Goldstein, R.M., and Hambrook, J.A., 2002, Revised protocols for sampling algal, invertebrate, and fish communities as part of the National Water-Quality Assessment Program: U.S. Geological Survey Open-File Report 02-150, 75 p.

Mueller, D.K., and Spahr, N.E., 2006, Nutrients in streams and rivers across the Nation-1992-2001: U.S. Geological Survey Scientific Investigations Report 2006-5107, $44 \mathrm{p}$.

Newell, A.J., Johnson, D.W., and Allen, L.K., 1987, Niagara River biota contamination project: fish flesh criteria for piscivorous wildlife: New York State Department of Environmental Conservation, Division of Fish and Wildlife, Bureau of Environmental Protection, Technical Report 87-3, 182 p.

Novotny, V., and Chesters, G., 1981, Handbook of nonpoint pollution: New York, Van Nostrand Reinhold Company, $555 \mathrm{p}$.

Odum, E.P., 1971, Fundamentals of Ecology (3d ed.): Philadelphia, Pa., W.B. Saunders Company, 574 p.

Ohio Environmental Protection Agency, 1988, Biological criteria for the protection of aquatic life, v. II,: users manual for biological field assessment of Ohio surface waters: Ohio Environmental Protection Agency, Ecological Assessment Section, Division of Water Quality, Planning and Assessment, variously paginated.

Olson, M.L., and DeWild, J.F., 1999, Techniques for the collection and species-specific analysis of low levels of mercury in water, sediment, and biota, in Morganwalp, D.W., and Buxton, H.T., eds., U.S. Geological Survey Toxic Substances Hydrology Program-proceedings of the technical meeting, Charleston, S.C., March 8-12, 1999_-volume 2 of 3, Contamination of hydrologic systems and related ecosystems: U.S. Geological Survey Water-Resources Investigations Report 99-4018B, p. 191-200. 
Oregon State University, 1996, Metolachlor: Oregon State University, EXTOXNET-Extension Toxicology Network pesticide information profiles, accessed January 18, 2007 at http://extoxnet.orst.edu/pips/metolach.htm

Paul, M.J., and Meyer, J.L., 2001, Streams in the urban landscape: Annual Review of Ecology and Systematics, v. 32, p. 333-365.

Percival, S., Chalmers, R., Embrey, M., Hunter, P., Sellwood, J., and Wyn-Jones, P., 2004, Microbiology of waterborne diseases: Boston, Elsevier Academic Press, $480 \mathrm{p}$.

Plafkin, J.L., Barbour, M.T., Porter, K.D., Gross, S.K., and Hughes, R.M., 1989, Rapid bioassessment protocols for use in streams and rivers: benthic macroinvertebrates and fish: U.S. Environmental Protection Agency, Office of Water Regulations and Standards, EPA 440-4-89001 .

Porterfield, George, 1972, Computation of fluvial-sediment discharge: U.S. Geological Survey Techniques of Water-Resources Investigations, book 3, chap. C3, 66 p.

Prescott, G.W., 1962, Algae of the Western Great Lakes area (2d ed.): Dubuque, Iowa, W.C. Brown, 977 p.

Qureshi, A.A., Bulich, A.A., and Isenberg, D.L., 1998, Microtox toxicity test systems-where they stand today, in Wells, P.G., and others, eds., Microscale testing in aquatic toxicology: advances, techniques, and practice: Boca Raton, Fla., CRC Press, p. 185-200.

Rand, G.M., and Petrocelli, S.R., 1985, Fundamentals of aquatic toxicology: methods and applications: New York, Hemisphere Publishing Corp., 666 p.

Rantz, S.E., and others, 1982, Measurement and computation of streamflow: U.S. Geological Survey Water-Supply Paper 2175, 2 v., 631 p.

Robertson, D.M., Graczyk, D.J., Garrison, P.J., Wang, L., LaLiberte, G., and Bannerman, R., 2006, Nutrient concentrations and their relations to the biotic integrity of wadeable streams in Wisconsin: U.S. Geological Survey Professional Paper 1722, 139 p.

Schneider, M.A., Lutz, M.A., and others, 2004, Waterresources-related information for the Milwaukee Metropolitan Sewerage District planning area, Wisconsin, 1970-2002: U.S. Geological Survey Water-Resources Investigations Report 03-4240, 288 p.

Scudder, B.C., Sullivan, D.J., Fitzpatrick, F.A., and Rheaume, S.J., 1997, Trace elements and synthetic organic compounds in biota and streambed sediment of the Western Lake Michigan Drainages, 1992-1995: U.S. Geological Survey Water-Resources Investigations Report 97-4192, 34 p.
Simon, A., and Hupp, C.R., 1992, Geomorphic and vegetative recovery processes along modified stream channels of West Tennessee: U.S. Geological Survey Open-File Report 91-502, 142 p.

Simonson, T.D., Lyons, J., and Kanehl, P.D., 1994, Guidelines for evaluating fish habitat in Wisconsin streams: U.S. Department of Agriculture Forest Service, North Central Forest Experiment Station, General Technical Report NC-164, 36 p.

Simpson, J.M, Santo Domingo, J.W., and Reasoner, D.J., 2002, Microbial source tracking - state of science: Environmental Science \& Technology, v. 36, no. 24, p. 5279-5288.

Southeastern Wisconsin Regional Planning Commission, 1987, A water resources management plan for the Milwaukee Harbor Estuary_-volume 1, Inventory findings for ready public review: Southeastern Wisconsin Regional Planning Commission Planning Report 37, $514 \mathrm{p}$.

Southeastern Wisconsin Regional Planning Commission, 2000, SEWRPC digital land use inventory, 2000, Wisconsin Transverse Mercator (WTM 83/91) projection: Machine-readable files on CD-ROM.

Southeastern Wisconsin Regional Planning Commission, 2002a, Subbasins, 2002 (continuous updates), Wisconsin Transverse Mercator (WTM 83/91) projection: Machine-readable files on CD-ROM.

Southeastern Wisconsin Regional Planning Commission, 2002b, Subwatersheds, 2002 (continuous updates), Wisconsin Transverse Mercator (WTM 83/91) projection: Machine-readable files on CD-ROM.

Steuer, J.S., Fitzgerald, S.A., and Hall, D.W., 1999, Distribution and transport of polychlorinated biphenyls and associated particulates in the Milwaukee River System, Wisconsin, 1993-95: U.S. Geological Survey WaterResources Investigations Report 99-4100, 37 p.

Sullivan, P.J., Agardy, F.J., and Clark, J.J.J., 2005, The environmental science of drinking water: Burlington, Mass., Elsevier Butterworth-Heinemann, 368 p.

Taylor, M.R., and Harrison, P.T.C., 1999, Ecological effects of endocrine disruption: current evidence and research priorities: Chemosphere, v. 39, no. 8, p. 1237-1248.

U.S. Department of Commerce, National Oceanic and Atmospheric Administration, and National Climatic Data Center, 2003, Climatological data-Wisconsin: Ashville, N.C., Monthly Summaries, v. 108, nos. 10-12. 
U.S. Department of Commerce, National Oceanic and Atmospheric Administration, and National Climatic Data Center, 2004, Climatological data-Wisconsin: Ashville, N.C., Monthly Summaries, v. 109, nos. 1-12.

U.S. Department of Commerce, National Oceanic and Atmospheric Administration, and National Climatic Data Center, 2005, Climatological data-Wisconsin: Ashville, N.C., Monthly Summaries, v. 110, nos. 1-9.

U.S. Environmental Protection Agency, 1976, Quality criteria for water: U.S. Environmental Protection Agency, Office of Water Planning and Standards, EPA 440/976/023, $501 \mathrm{p}$.

U.S. Environmental Protection Agency, 1986, Ambient water quality criteria for bacteria-1986: U.S. Environmental Protection Agency, Office of Water Planning and Standards, EPA 440/5-84-002, 18 p.

U.S. Environmental Protection Agency, 1997, Special report on environmental endocrine disruption: an effects assessment and analysis: U.S. Environmental Protection Agency, Risk Assessment Forum, EPA/630/R-96/012, $111 \mathrm{p}$.

U.S. Environmental Protection Agency, 2000, Ambient water quality criteria recommendations, rivers and streams in Nutrient Ecoregion VII: U.S. Environmental Protection Agency, Office of Water, EPA 822-B-00018, 20 p., 3 appendixes.

U.S. Environmental Protection Agency, 2001, Water quality criterion for the protection of human health: methylmercury: U.S. Environmental Protection Agency, Office of Water, Office of Science and Technology, EPA 823-R-01-001, accessed January 18, 2007 at http:// www.epa.gov/waterscience/criteria/methylmercury/ document.html

U.S. Environmental Protection Agency, 2005a, Method 1623: Cryptosporidium and Giardia in water by filtration/IMS/FA: U.S. Environmental Protection Agency, Office of Water, EPA 815-R-05-002, 68 p.

U.S. Environmental Protection Agency, 2005b, Pesticides: topical \& chemical fact sheets - the insect repellent DEET: U.S. Environmental Protection Agency, accessed January 18, 2007, at http://www.epa.gov/pesticides/ factsheets/chemicals/deet.htm

U.S. Environmental Protection Agency, 2006a, Data collection and modeling of enteric pathogens, fecal indicators and real-time environmental data at Madison, Wisconsin recreational beaches for timely public access to water quality information: U.S. Environmental Protection Agency, accessed January 18, 2007, at http:// www.cityofmadison.com/hebeachstatic/docs/Final\%20E MPACT\%20Project\%20Report\%206-24-04.pdf
U.S. Environmental Protection Agency, 2006b, Region 5 cleanup sites-Cedar Creek site: U.S. Environmental Protection Agency, accessed January 18, 2007, at http:// www.epa.gov/Region5/sites/cedarcreek/index.htm

U.S. Environmental Protection Agency, 2006c, Superfund information systems-Superfund site progress profile Moss-American Co., Inc. (Kerr-McGee Oil Co.): U.S. Environmental Protection Agency, accessed January 18, 2007, at http://cfpub.epa.gov/supercpad/cursites/ csitinfo.cfm? $\mathrm{id}=0505024$

U.S. Environmental Protection Agency, 2006d, Water quality criteria_current national recommended water quality criteria: U.S. Environmental Protection Agency, accessed January 18, 2007, at http://epa.gov/ waterscience/criteria/wqcriteria.html

U.S. Geological Survey, variously dated, National field manual for the collection of water-quality data: U.S. Geological Survey Techniques of Water-Resources Investigations, Book 9, Chapters A1-A9, accessed January 18, 2007, at http://water.usgs.gov/owq/FieldManual/

University of Wisconsin-Extension and Southeastern Wisconsin Regional Planning Commission, 2004, Plan on it-environmental corridors, lifelines of the natural resource base: University of Wisconsin-Extension, accessed January 18, 2007, at http://www.sewrpc. org/publications/brochure/plan_on_it_environmental_ corridors.pdf

Vannote, R.L., Minshall, G.W., Cummins, K.W., Sedell, J.R., and Cushing, C.E., 1980, The river continuum concept: Canadian Journal of Fisheries and Aquatic Sciences, v. 37, p. 130-137.

Wang, Lizhu, Lyons, J., and Kanehl, P.D., 2001, Impacts of urbanization on stream habitat and fish across multiple spatial scales: Environmental Management, v. 28, no. 2, p. 255-266.

Waschbusch, R.J., Olson, D.L., Marsh, S.B., and Stark, P.A., 2005, Water Resources Data, Wisconsin, water year 2004: U.S. Geological Survey Water Data Report WI-04-1, $990 \mathrm{p}$.

Waschbusch, R.J., Olson, D.L., and Marsh, S.B., 2006, Water Resources Data, Wisconsin, water year 2005: U.S. Geological Survey Water Data Report WI-05-1, $982 \mathrm{p}$.

Waschbusch, R.J., Selbig, W.R., and Bannerman, R.T., 1999, Sources of phosphorus in stormwater and street dirt from two urban residential basins in Madison, Wisconsin, 1994-95: U.S. Geological Survey Water Resources Investigations Report 99-4021, 47 p. 
Wehr, J.D., and Sheath, R.G., 2003, Freshwater algae of North America: Ecology and classification: San Diego, Calif., Academic Press, 918 p.

Wiener, J.G., Krabbenhoft, D.P., Heinz, G.H., and Scheuhammer, A.M., 2003, Ecotoxicology of mercury, chap. 16 in Hoffman, D.J., Rattner, B.A., Burton, G.A., Jr., and Cairns, J., Jr., eds., Handbook of ecotoxicology (2d ed.): Boca Raton, Fla., Lewis Publishers, p. 409-463.

Wiener, J.G., and Spry, D.J., 1996, Toxicological significance of mercury in freshwater fish, in Beyer, W.N., Heinz, G.H., and Redmon-Norwood, A.W., eds., Environmental contaminants in wildlife: interpreting tissue concentrations: Boca Raton, FL, Lewis Publishers, p. 297-339.

Wisconsin Department of Natural Resources, [n.d.], Beach monitoring program requirements: Wisconsin Department of Natural Resources, accessed December 18, 2006, at http://www.dnr.state.wi.us/org/water/wm/wqs/ beaches/

Wisconsin Department of Natural Resources, 1998, WISCLAND land cover (WLCGW930)-1992, Wisconsin Transverse Mercator (WTM 83/91) projection: Wisconsin Department of Natural Resources, machine-readable files on CD-ROM.

Wisconsin Department of Natural Resources, 2006, Choose wisely - a health guide for eating fish in Wisconsin: Wisconsin Department of Natural Resources, PUB-FH-824 2006, 20 p.

Zaugg, S.D., Smith, S.G., Schroeder, M.P., Barber, L.B., and Burkhardt, M.R., 2002, Methods of analysis by the U.S. Geological Survey National Water Quality Laboratory-determination of wastewater compounds by polystyrene-divinylbenzene solid-phase extraction and capillary-column gas chromatography/mass spectrometry: U.S. Geological Survey Water-Resources Investigations Report 01-4186, 37 p. 


\section{Appendixes}


Appendix 1. Land-use classes from Southeastern Wisconsin Regional Planning Commission (SEWRPC) and Wisconsin Department of Natural Resources WISCLAND land-cover data sets.

\begin{tabular}{|c|c|c|c|c|}
\hline $\begin{array}{c}\text { MMSD } \\
\text { Phase II use }\end{array}$ & SEWRPC 2000 classification & $\begin{array}{l}\text { SEWRPC } \\
\text { code }\end{array}$ & WISCLAND classification & WISCLAND code \\
\hline Residential & Residential & $100 \mathrm{~s}$ & Urban/developed, low intensity & 104 \\
\hline \multirow[t]{2}{*}{ Commercial } & Commercial & $200 s$ & & \\
\hline & Cultural outdoor & $711-712$ & & \\
\hline Industrial & Industrial & $300 \mathrm{~s}$ & Urban/developed, high intensity & 101 \\
\hline Transportation & Transportation & $400 \mathrm{~s}$ & & \\
\hline \multirow[t]{5}{*}{ Other urban } & Communication and utilities & $500 \mathrm{~s}$ & Urban/developed, golf course & 105 \\
\hline & Institutional and governmental services & $600 \mathrm{~s}$ & & \\
\hline & Land-related outdoor recreation areas & $731-732$ & & \\
\hline & Water-related outdoor recreation sites & $781-782$ & & \\
\hline & $\begin{array}{l}\text { Outdoor recreation area under } \\
\text { development }\end{array}$ & 799 & & \\
\hline Agriculture & Agriculture & $800 \mathrm{~s}$ & Agriculture & $\begin{array}{l}110 \mathrm{~s}, 120 \mathrm{~s} \\
130 \mathrm{~s}, 140 \mathrm{~s}\end{array}$ \\
\hline $\begin{array}{l}\text { Natural areas and } \\
\text { other lands }\end{array}$ & Natural areas and other lands & $900 \mathrm{~s}$ & Forest & $\begin{array}{l}\text { 150s, 160-194, } \\
\text { 200, 210-220, } \\
222-234, \\
240 \mathrm{~s}, 250, \\
255\end{array}$ \\
\hline
\end{tabular}


Appendix 2A-B. Descriptions of methods for harbor-site sampling and mercury sampling.

Appendix 2A. Modified sampling technique for MMSD harbor sites, 2004-2005

\section{Regular samples}

- Kemmerer sampler

- Fill pickle jar with 9 liters to make composite sample.

- Field clean equipment between sampling locations.

- Weighted sampler

- Fill three baked 1-liter amber glass bottles for:

- Dissolved organic carbon (DOC) and total particulate carbon and nitrogen analysis

- Pesticides analysis

- Wastewater analysis

- Field measurements (dissolved oxygen (DO), temperature, pH, and specific conductance)

- Three measurements—one measurement at each of three depths

QA/OC samples: These samples are collected in association with regularly collected samples and are also done at a specified frequency.

- Blanks: A blank is run after a regular sample is collected and equipment has been cleaned.

- Samples regularly collected with Kemmerer sampler

- Fill sampler with universal blank water then dump into pickle jar, as one would a sample

- Samples regularly collected with weighted sampler

- Fill 1-L glass bottles with universal blank water, cap

- No field measurements are made on universal blank water

- Sample time recorded as 1 minute before the regular sample's time

\section{- Replicates:}

- Kemmerer sampler

- Collect replicate samples immediately after the original sample has been collected, in the same manner

- Weighted sampler

- Collect replicate samples immediately after the regular sample has been collected, in the same manner

- No additional field measurements are needed; use the ones from the regular sample

- Sample time is recorded as 1 minute after the regular sample's time 
Appendix 2B. Mercury sampling

Whole-water samples were collected whenever possible from the centroid of flow by field personnel wearing arm-length gloves and submersing a 1-L PETG (glycolmodified polyethylene terephthalate) bottle. The filled bottle was hermetically sealed in a re-sealable clear plastic bag and immediately placed in a cooler for transport to the USGS Wisconsin Mercury Research Laboratory in Middleton, Wis. Once at the lab, the water samples were filtered to separate the dissolved and particulate associated fractions of methylmercury and total mercury. Sample filtration was done by use of an acid-cleaned, plastic filtration dome, baked (at $500^{\circ} \mathrm{C}$ ); quartz fiber filters (QFFs); a vacuum pump, and a Teflon sample tower. In this procedure, the sample is exposed to ambient air for a few minutes and only contacts Teflon surfaces that have been rigorously cleaned in hot acid, thoroughly rinsed with deionized water, and then double-bagged until use. Filtered water samples for total mercury and methylmercury analysis were preserved by adding concentrated $\mathrm{HCl}$ to 1 percent by volume. Particulates retained on the QFFs during filtration were immediately placed in Teflon petri dishes, sealed in clear plastic bags, and kept frozen until analysis.
A brief description of the analytical procedures for total mercury and methylmercury water and suspended particulates is given here but a complete description can be found in Olson and DeWild (1999), Dewild and others (2004), and Olund and others (2004). Total mercury and methylmercury determinations were done at the USGS Wisconsin Mercury Research Laboratory, a facility specifically designed and dedicated for low-level speciation analysis of environmental samples for mercury. Total mercury was determined by cold vapor atomic fluorescence spectroscopy (CVAFS) following oxidation with $\mathrm{BrCl}$ at $50^{\circ} \mathrm{C}$, reduction by $\mathrm{SnCl}^{2}$, and purge and trap of the evolved $\mathrm{Hg}^{0}$ onto gold-coated glass bead columns. The analytical procedure for methylmercury is a two-step process involving distillation of the sample to separate the methylmercury from potential matrix-interference effects of dissolved organic carbon (DOC), followed by aqueous phase ethylation and quantification using gas chromatography and CVAFS. Ancillary chemical data to assist in the interpretation of the results were determined by the following methods: $\mathrm{pH}$ was measured in the field with a calibrated probe, sulfate by ion chromatography, and DOC by a carbon analyzer that employs acidification and persulfate/UV oxidation. 
Appendix 3. Water-quality properties and constituents, reporting levels, and analyzing laboratories.

Table 3-1. Automatically collected samples

Analyzing laboratory: Wisconsin State Lab of Hygiene, Madison, Wis. (WSLH)

[mg/L, milligram per liter]

\begin{tabular}{lcccc}
\hline \multicolumn{1}{c}{ Constituent } & $\begin{array}{c}\text { Parameter } \\
\text { code }\end{array}$ & $\begin{array}{c}\text { Reporting } \\
\text { level }\end{array}$ & Reporting units & Analyzing lab \\
\hline Chloride, water, filtered & 00940 & 0.2 & $\mathrm{mg} / \mathrm{L}$ & WSLH \\
Phosphorus, water, unfiltered & 00665 & .004 & $\mathrm{mg} / \mathrm{L}$ & WSLH \\
Suspended sediment concentration & 80154 & 1 & $\mathrm{mg} / \mathrm{L}$ & WSLH \\
\hline
\end{tabular}

Table 3-2. Field parameters

[mg/L, milligram per liter; $\mu \mathrm{S} / \mathrm{cm}$, microsiemen per centimeter; ${ }^{\circ} \mathrm{C}$, degrees Celsius; --, not available]

\begin{tabular}{lcccc}
\hline \multicolumn{1}{c}{ Constituent } & $\begin{array}{c}\text { Parameter } \\
\text { code }\end{array}$ & $\begin{array}{c}\text { Reporting } \\
\text { level }\end{array}$ & Reporting units & Analyzing lab \\
\hline Alkalinity, water, filtered, incremental titration, field & 39086 & -- & $\mathrm{mg} / \mathrm{L}$ as calcium \\
carbonate & None (field) \\
Dissolved oxygen, water, unfiltered & 00300 & -- & $\mathrm{mg} / \mathrm{L}$ & None (field) \\
pH, water, unfiltered, field & 00400 & -- & standard units & None (field) \\
Specific conductance, water, unfiltered & 00095 & -- & $\mu \mathrm{SS} / \mathrm{cm}$ at $25^{\circ} \mathrm{C}$ & None (field) \\
Temperature, water & 00010 & -- & ${ }^{\circ} \mathrm{C}$ & None (field) \\
Temperature, air & 00020 & -- & ${ }^{\circ} \mathrm{C}$ & None (field) \\
\hline
\end{tabular}

Table 3-3. Dissolved and particulate carbon and particulate nitrogen (Schedule 2631 and Lab Code 2613) Analyzing laboratory: USGS National Water Quality Laboratory, Denver, Colo. (NWQL)

$[\mathrm{mg} / \mathrm{L}$, milligram per liter]

\begin{tabular}{lcccc}
\hline \multicolumn{1}{c}{ Constituent } & $\begin{array}{c}\text { Parameter } \\
\text { code }\end{array}$ & $\begin{array}{c}\text { Reporting } \\
\text { level }\end{array}$ & Reporting units & Analyzing lab \\
\hline $\begin{array}{l}\text { Carbon (inorganic plus organic), suspended sediment, } \\
\text { total }\end{array}$ & 00694 & 0.12 & $\mathrm{mg} / \mathrm{L}$ & $\mathrm{NWQL}$ \\
$\begin{array}{l}\text { Inorganic carbon, suspended sediment, total } \\
\text { Organic carbon, suspended sediment, total }\end{array}$ & 00688 & .12 & $\mathrm{mg} / \mathrm{L}$ & $\mathrm{NWQL}$ \\
Organic carbon, water, filtered & 00689 & .12 & $\mathrm{mg} / \mathrm{L}$ & $\mathrm{NWQL}$ \\
Particulate nitrogen, suspended in water & 00681 & .33 & $\mathrm{mg} / \mathrm{L}$ & $\mathrm{NWQL}$ \\
\hline
\end{tabular}


Appendix 3. Water-quality properties and constituents, reporting levels, and analyzing laboratories—Continued.

Table 3-4. Miscellaneous water-quality measurements

Analyzing laboratories: Wisconsin State Lab of Hygiene, Madison, Wis. (WSLH); USGS National Water Quality Laboratory, Denver, Colo. (NWQL); USGS lowa Water Science Center Sediment Laboratory in lowa City, lowa (IWSC-SL); USGS Kentucky Water Science Center Sediment Laboratory in Louisville, Ky. (KWSC-SL)

[ $\mu \mathrm{g} / \mathrm{L}$, microgram per liter; ${ }^{\circ} \mathrm{C}$, degrees Celsius; $\mathrm{mg} / \mathrm{L}$, milligram per liter; $\mu \mathrm{S} / \mathrm{cm}$, microsiemen per centimeter; --, not available]

\begin{tabular}{|c|c|c|c|c|}
\hline Constituent & $\begin{array}{l}\text { Parameter } \\
\text { code }\end{array}$ & $\begin{array}{c}\text { Reporting } \\
\text { level }\end{array}$ & Reporting units & Analyzing lab \\
\hline $\begin{array}{l}\text { Alkalinity, water, filtered, fixed endpoint ( } \mathrm{pH} 4.5 \text { ) } \\
\text { titration, laboratory }\end{array}$ & 29801 & 5 & $\begin{array}{l}\mathrm{mg} / \mathrm{L} \text { as calcium } \\
\text { carbonate }\end{array}$ & NWQL \\
\hline $\begin{array}{l}\text { Chlorophyll } a \text {, water, unfiltered, trichromatic method, } \\
\text { uncorrected }\end{array}$ & 32210 & .26 & $\mu \mathrm{g} / \mathrm{L}$ & WSLH \\
\hline $\begin{array}{l}\text { Biochemical oxygen demand, water, unfiltered, } 5 \text { days } \\
\text { at } 20^{\circ} \mathrm{C}\end{array}$ & 00310 & 2 & $\mathrm{mg} / \mathrm{L}$ & WSLH \\
\hline Chemical oxygen demand, low level, water, unfiltered & 00335 & 9 & $\mathrm{mg} / \mathrm{L}$ & WSLH \\
\hline Microtox Acute Toxicity Test, water & -- & -- & percent effect & WSLH \\
\hline $\mathrm{pH}$, water, unfiltered, laboratory & 00403 & .1 & standard units & NWQL \\
\hline Specific conductance, water, unfiltered, laboratory & 90095 & 2.6 & $\mu \mathrm{S} / \mathrm{cm}$ at $25^{\circ} \mathrm{C}$ & NWQL \\
\hline Suspended sediment concentration & 80154 & 1 & $\mathrm{mg} / \mathrm{L}$ & $\begin{array}{l}\text { IWSC-SL (2004), } \\
\text { KWSC-SL (2005) }\end{array}$ \\
\hline
\end{tabular}

Table 3-5. Major inorganics (Schedule 2701)

Analyzing laboratory: USGS-National Water Quality Laboratory, Denver, Colo. (NWQL)

[mg/L, milligram per liter; $\mu \mathrm{g} / \mathrm{L}$, microgram per liter; $\mu \mathrm{S} / \mathrm{cm}$, microsiemen per centimeter; ${ }^{\circ} \mathrm{C}$, degrees Celsius]

\begin{tabular}{lcccc}
\hline \multicolumn{1}{c}{ Constituent } & $\begin{array}{c}\text { Parameter } \\
\text { code }\end{array}$ & $\begin{array}{c}\text { Reporting } \\
\text { level }\end{array}$ & Reporting units & Analyzing lab \\
\hline Calcium, water, filtered & 00915 & 0.01 & $\mathrm{mg} / \mathrm{L}$ & $\mathrm{NWQL}$ \\
Chloride, water, filtered & 00940 & .2 & $\mathrm{mg} / \mathrm{L}$ & $\mathrm{NWQL}$ \\
Fluoride, water, filtered & 00950 & .17 & $\mathrm{mg} / \mathrm{L}$ & $\mathrm{NWQL}$ \\
Iron, water, filtered & 01046 & 6.4 & $\mu \mathrm{g} / \mathrm{L}$ & $\mathrm{NWQL}$ \\
Magnesium, water, filtered & 00925 & .008 & $\mathrm{mg} / \mathrm{L}$ & $\mathrm{NWQL}$ \\
Manganese, water, filtered & 01056 & .8 & $\mu \mathrm{g} / \mathrm{L}$ & $\mathrm{NWQL}$ \\
pH, water, unfiltered, laboratory & 00403 & .1 & $\mathrm{standard}$ units & $\mathrm{NWQL}$ \\
Potassium, water, filtered & 00935 & .16 & $\mathrm{mg} / \mathrm{L}$ & $\mathrm{NWQL}$ \\
Residue on evaporation, dried at $180^{\circ} \mathrm{C}$, water, filtered & 70300 & 10 & $\mathrm{mg} / \mathrm{L}$ & $\mathrm{NWQL}$ \\
Silica, water, filtered & 00955 & .04 & $\mathrm{mg} / \mathrm{L}$ & $\mathrm{NWQL}$ \\
Sodium, water, filtered & 00930 & .1 & $\mathrm{mg} / \mathrm{L}$ & $\mathrm{NWQL}$ \\
Specific conductance, water, unfiltered, laboratory & 90095 & 2.6 & $\mu \mathrm{S} / \mathrm{cm} \mathrm{at} 25^{\circ} \mathrm{C}$ & $\mathrm{NWQL}$ \\
Sulfate, water, filtered & 00945 & .18 & $\mathrm{mg} / \mathrm{L}$ & $\mathrm{NWQL}$ \\
\hline
\end{tabular}


Appendix 3. Water-quality properties and constituents, reporting levels, and analyzing laboratories—Continued.

Table 3-6. Nutrients (Schedule 2711)

Analyzing laboratory: USGS-National Water Quality Laboratory, Denver, Colo. (NWOL)

[mg/L, milligram per liter]

\begin{tabular}{|c|c|c|c|c|}
\hline Constituent & $\begin{array}{l}\text { Parameter } \\
\text { code }\end{array}$ & $\begin{array}{l}\text { Reporting } \\
\text { level }\end{array}$ & Reporting units & Analyzing lab \\
\hline Ammonia, water, filtered & 00608 & 0.04 & $\mathrm{mg} / \mathrm{L}$ as nitrogen & NWQL \\
\hline Nitrite, water, filtered & 00613 & .008 & $\mathrm{mg} / \mathrm{L}$ as nitrogen & NWQL \\
\hline Nitrite plus nitrate, water, filtered & 00631 & .06 & $\mathrm{mg} / \mathrm{L}$ as nitrogen & NWQL \\
\hline $\begin{array}{l}\text { Total nitrogen (nitrate }+ \text { nitrite }+ \text { ammonia }+ \text { organic } \\
\text { nitrogen), water, unfiltered, analytically determined }\end{array}$ & 62855 & .03 & $\mathrm{mg} / \mathrm{L}$ as nitrogen & NWQL \\
\hline Orthophosphate, water, filtered & 00671 & .006 & $\mathrm{mg} / \mathrm{L}$ as phosphorus & NWQL \\
\hline Phosphorus, water, unfiltered & 00665 & .004 & $\mathrm{mg} / \mathrm{L}$ & NWQL \\
\hline
\end{tabular}

Table 3-7. Mercury

Analyzing laboratory: USGS-Wisconsin Mercury Research Laboratory, Middleton, Wis. (WMRL)

[ng/L, nanogram per liter]

\begin{tabular}{lcccc}
\hline \multicolumn{1}{c}{ Constituent } & $\begin{array}{c}\text { Parameter } \\
\text { code }\end{array}$ & $\begin{array}{c}\text { Reporting } \\
\text { level }\end{array}$ & Reporting units & Analyzing lab \\
\hline $\begin{array}{c}\text { Mercury, suspended sediment, total } \\
\text { (particulate total mercury) }\end{array}$ & 62976 & 0.062 & $\mathrm{ng} / \mathrm{L}$ & $\mathrm{WMRL}$ \\
$\begin{array}{c}\text { Mercury, water, filtered } \\
\quad \text { (dissolved total mercury) }\end{array}$ & 50287 & .04 & $\mathrm{ng} / \mathrm{L}$ & $\mathrm{WMRL}$ \\
$\begin{array}{c}\text { Methylmercury, suspended sediment, total } \\
\quad \text { (particulate methylmercury) }\end{array}$ & 62977 & .01 & $\mathrm{ng} / \mathrm{L}$ & $\mathrm{WMRL}$ \\
$\begin{array}{c}\text { Methylmercury, water, filtered, recoverable } \\
\text { (dissolved methylmercury) }\end{array}$ & 50285 & .04 & $\mathrm{ng} / \mathrm{L}$ & $\mathrm{WMRL}$ \\
\hline
\end{tabular}


Appendix 3. Water-quality properties and constituents, reporting levels, and analyzing laboratories—Continued.

Table 3-8. Indicator and pathogenic microorganisms

Analyzing laboratories: Milwaukee Metropolitan Sewerage District, Milwaukee, Wis. (MMSD); Wisconsin State Lab of Hygiene, Madison, Wis. (WSLH)

[MPN/100 mL, most probable number per 100 milliliters; col/100 mL, colonies per 100 milliliters; plaques/100mL, plaques per $100 \mathrm{milliliters;} \mathrm{mL,}$ milliliter; cysts/100 mL, cysts per 100 milliliters; oocysts/100 mL, oocysts per 100 milliliters; --, not available]

\begin{tabular}{|c|c|c|c|c|}
\hline Constituent & $\begin{array}{c}\text { Parameter } \\
\text { code }\end{array}$ & $\begin{array}{c}\text { Reporting } \\
\text { level }\end{array}$ & Reporting units & Analyzing lab \\
\hline Escherichia coli & -- & 1 & MPN/100 mL & MMSD \\
\hline Fecal coliform & -- & 3 & $\mathrm{col} / 100 \mathrm{~mL}$ & MMSD \\
\hline Escherichia coli & 50468 & 1 & MPN/100 mL & WSLH \\
\hline Fecal coliform & 31625 & 10 & $\mathrm{col} / 100 \mathrm{~mL}$ & WSLH \\
\hline Coliphage & 90904 & 1 & plaques/100 mL & WSLH \\
\hline Coliphage, groups I and IV & -- & 1 & count & WSLH \\
\hline Coliphage, groups II and III & -- & 1 & count & WSLH \\
\hline Escherichia coli O157:H8 & 31683 & $\begin{array}{l}\text { Presence/ } \\
\text { absence }\end{array}$ & $\begin{array}{c}\text { presence or absence } \\
\text { per } 500 \mathrm{~mL}\end{array}$ & WSLH \\
\hline Giardia & 61229 & $\begin{array}{l}30.3 \\
31.3 \\
32.3 \\
33.3 \\
34.5 \\
35.7 \\
37 \\
38.7 \\
40 \\
43.8 \\
51.6 \\
53.3 \\
58.8 \\
66.7 \\
72.7 \\
77.4 \\
80\end{array}$ & cysts/100 L & WSLH \\
\hline Cryptosporidium & 61230 & $\begin{array}{c}233, \\
28.6, \\
30.3, \\
31.3, \\
32.3, \\
33.3, \\
37, \\
46.7, \\
51.6, \\
53.3, \\
58.8, \\
64.5, \\
66.7, \\
77.4\end{array}$ & oocysts/100 L & WSLH \\
\hline Salmonella & 31681 & $\begin{array}{l}0.1 \\
0.2\end{array}$ & MPN/100 mL & WSLH \\
\hline
\end{tabular}


Appendix 3. Water-quality properties and constituents, reporting levels, and analyzing laboratories—Continued.

Table 3-9. Pesticides and degradates (Schedule 2003)

Analyzing laboratory: USGS-National Water Quality Laboratory, Denver, Colo. (NWOL)

[ug/L, microgram per liter]

\begin{tabular}{|c|c|c|c|c|}
\hline Constituent & $\begin{array}{l}\text { Parameter } \\
\text { code }\end{array}$ & $\begin{array}{c}\text { Reporting } \\
\text { level }\end{array}$ & $\begin{array}{l}\text { Reporting } \\
\text { units }\end{array}$ & $\begin{array}{c}\text { Analyzing } \\
\text { lab }\end{array}$ \\
\hline Acetochlor, water, filtered, recoverable & 49260 & 0.006 & $\mu \mathrm{g} / \mathrm{L}$ & NWQL \\
\hline Alachlor, water, filtered, recoverable & 46342 & .005 & $\mu \mathrm{g} / \mathrm{L}$ & NWQL \\
\hline Atrazine, water, filtered, recoverable & 39632 & .007 & $\mu \mathrm{g} / \mathrm{L}$ & NWQL \\
\hline Azinphos-methyl oxygen analog, water, filtered, recoverable & 61635 & .042 & $\mu \mathrm{g} / \mathrm{L}$ & NWQL \\
\hline Azinphos-methyl, water, filtered ( 0.7 micron glass fiber filter), recoverable & 82686 & .08 & $\mu \mathrm{g} / \mathrm{L}$ & NWQL \\
\hline Benfluralin, water, filtered ( 0.7 micron glass fiber filter), recoverable & 82673 & .01 & $\mu \mathrm{g} / \mathrm{L}$ & NWQL \\
\hline Bromacil, water, filtered, recoverable & 04029 & .5 & $\mu \mathrm{g} / \mathrm{L}$ & NWQL \\
\hline Carbaryl, water, filtered ( 0.7 micron glass fiber filter), recoverable & 82680 & .06 & $\mu \mathrm{g} / \mathrm{L}$ & NWQL \\
\hline 2-Chloro-2',6'-diethylacetanilide, water, filtered, recoverable & 61618 & .0065 & $\mu \mathrm{g} / \mathrm{L}$ & NWQL \\
\hline 2-Chloro-4-isopropylamino-6-amino-s-triazine, water, filtered, recoverable & 04040 & .014 & $\mu \mathrm{g} / \mathrm{L}$ & NWQL \\
\hline 4-Chloro-2-methylphenol, water, filtered, recoverable & 61633 & .005 & $\mu \mathrm{g} / \mathrm{L}$ & NWQL \\
\hline Chlorpyrifos oxygen analog, water, filtered, recoverable & 61636 & .0562 & $\mu \mathrm{g} / \mathrm{L}$ & NWQL \\
\hline Chlorpyrifos, water, filtered, recoverable & 38933 & .005 & $\mu \mathrm{g} / \mathrm{L}$ & NWQL \\
\hline cis-Permethrin, water, filtered ( 0.7 micron glass fiber filter), recoverable & 82687 & .01 & $\mu \mathrm{g} / \mathrm{L}$ & NWQL \\
\hline Cyfluthrin, water, filtered, recoverable & 61585 & .053 & $\mu \mathrm{g} / \mathrm{L}$ & NWQL \\
\hline Cypermethrin, water, filtered, recoverable & 61586 & .046 & $\mu \mathrm{g} / \mathrm{L}$ & NWQL \\
\hline DCPA, water, filtered ( 0.7 micron glass fiber filter), recoverable & 82682 & .003 & $\mu \mathrm{g} / \mathrm{L}$ & NWQL \\
\hline Desulfinyl fipronil, water, filtered, recoverable & 62170 & .012 & $\mu \mathrm{g} / \mathrm{L}$ & NWQL \\
\hline Diazinon oxygen analog, water, filtered, recoverable & 61638 & .006 & $\mu \mathrm{g} / \mathrm{L}$ & NWQL \\
\hline Diazinon, water, filtered, recoverable & 39572 & .005 & $\mu \mathrm{g} / \mathrm{L}$ & NWQL \\
\hline 3,4-Dichloroaniline, water, filtered, recoverable & 61625 & .0045 & $\mu \mathrm{g} / \mathrm{L}$ & NWQL \\
\hline Dicrotophos, water, filtered, recoverable & 38454 & .0843 & $\mu \mathrm{g} / \mathrm{L}$ & NWQL \\
\hline Dieldrin, water, filtered, recoverable & 39381 & .009 & $\mu \mathrm{g} / \mathrm{L}$ & NWQL \\
\hline 2,6-Diethylaniline, water, filtered (0.7-micron glass fiber filter), recoverable & 82660 & .006 & $\mu \mathrm{g} / \mathrm{L}$ & NWQL \\
\hline Dimethoate, water, filtered (0.7-micron glass fiber filter), recoverable & 82662 & .0061 & $\mu \mathrm{g} / \mathrm{L}$ & NWQL \\
\hline Ethion monoxon, water, filtered, recoverable & 61644 & .021 & $\mu \mathrm{g} / \mathrm{L}$ & NWQL \\
\hline Ethion, water, filtered, recoverable & 82346 & .016 & $\mu \mathrm{g} / \mathrm{L}$ & NWQL \\
\hline 2-Ethyl-6-methylaniline, water, filtered, recoverable & 61620 & .01 & $\mu \mathrm{g} / \mathrm{L}$ & NWQL \\
\hline Fenamiphos sulfone, water, filtered, recoverable & 61645 & .053 & $\mu \mathrm{g} / \mathrm{L}$ & NWQL \\
\hline Fenamiphos sulfoxide, water, filtered, recoverable & 61646 & .04 & $\mu \mathrm{g} / \mathrm{L}$ & NWQL \\
\hline Fenamiphos, water, filtered, recoverable & 61591 & .029 & $\mu \mathrm{g} / \mathrm{L}$ & NWQL \\
\hline Desulfinylfipronil amide, water, filtered, recoverable & 62169 & .029 & $\mu \mathrm{g} / \mathrm{L}$ & NWQL \\
\hline Fipronil sulfide, water, filtered, recoverable & 62167 & .013 & $\mu \mathrm{g} / \mathrm{L}$ & NWQL \\
\hline Fipronil sulfone, water, filtered, recoverable & 62168 & .024 & $\mu \mathrm{g} / \mathrm{L}$ & NWQL \\
\hline Fipronil, water, filtered, recoverable & 62166 & .016 & $\mu \mathrm{g} / \mathrm{L}$ & NWQL \\
\hline Fonofos, water, filtered, recoverable & 04095 & .006 & $\mu \mathrm{g} / \mathrm{L}$ & NWQL \\
\hline
\end{tabular}


Appendix 3. Water-quality properties and constituents, reporting levels, and analyzing laboratories—Continued.

Table 3-9. Pesticides and degradates (Schedule 2003) — Continued

Analyzing laboratory: USGS-National Water Quality Laboratory, Denver, Colo. (NWQL)

$[\mu \mathrm{g} / \mathrm{L}$, microgram per liter]

\begin{tabular}{|c|c|c|c|c|}
\hline Constituent & $\begin{array}{c}\text { Parameter } \\
\text { code }\end{array}$ & $\begin{array}{c}\text { Reporting } \\
\text { level }\end{array}$ & $\begin{array}{c}\text { Reporting } \\
\text { units }\end{array}$ & $\begin{array}{c}\text { Analyzing } \\
\text { lab }\end{array}$ \\
\hline Hexazinone, water, filtered, recoverable & 04025 & 0.026 & $\mu \mathrm{g} / \mathrm{L}$ & NWQL \\
\hline Indole, water, filtered, recoverable & 62076 & .5 & $\mu \mathrm{g} / \mathrm{L}$ & NWQL \\
\hline Iprodione, water, filtered, recoverable & 61593 & .026 & $\mu \mathrm{g} / \mathrm{L}$ & NWQL \\
\hline Isofenphos, water, filtered, recoverable & 61594 & .011 & $\mu \mathrm{g} / \mathrm{L}$ & NWQL \\
\hline Malaoxon, water, filtered, recoverable & 61652 & .039 & $\mu \mathrm{g} / \mathrm{L}$ & NWQL \\
\hline Malathion, water, filtered, recoverable & 39532 & .016 & $\mu \mathrm{g} / \mathrm{L}$ & NWQL \\
\hline Metalaxyl, water, filtered, recoverable & 61596 & .0069 & $\mu \mathrm{g} / \mathrm{L}$ & NWQL \\
\hline Methidathion, water, filtered, recoverable & 61598 & .0087 & $\mu \mathrm{g} / \mathrm{L}$ & NWQL \\
\hline Methyl paraoxon, water, filtered, recoverable & 61664 & .019 & $\mu \mathrm{g} / \mathrm{L}$ & NWQL \\
\hline Methyl parathion, water, filtered (0.7-micron glass fiber filter), recoverable & 82667 & .008 & $\mu \mathrm{g} / \mathrm{L}$ & NWQL \\
\hline Metolachlor, water, filtered, recoverable & 39415 & .01 & $\mu \mathrm{g} / \mathrm{L}$ & NWQL \\
\hline Metribuzin, water, filtered, recoverable & 82630 & .012 & $\mu \mathrm{g} / \mathrm{L}$ & NWQL \\
\hline Myclobutanil, water, filtered, recoverable & 61599 & .033 & $\mu \mathrm{g} / \mathrm{L}$ & NWQL \\
\hline 1-Naphthol, water, filtered (0.7-micron glass fiber filter), recoverable & 49295 & .0882 & $\mu \mathrm{g} / \mathrm{L}$ & NWQL \\
\hline Pendimethalin, water, filtered (0.7-micron glass fiber filter), recoverable & 82683 & .02 & $\mu \mathrm{g} / \mathrm{L}$ & NWQL \\
\hline Phorate oxygen analog, water, filtered, recoverable & 61666 & .027 & $\mu \mathrm{g} / \mathrm{L}$ & NWQL \\
\hline Phorate, water, filtered (0.7-micron glass fiber filter), recoverable & 82664 & .02 & $\mu \mathrm{g} / \mathrm{L}$ & NWQL \\
\hline Phosmet oxygen analog, water, filtered, recoverable & 61668 & .0511 & $\mu \mathrm{g} / \mathrm{L}$ & NWQL \\
\hline Phosmet, water, filtered, recoverable & 61601 & .0079 & $\mu \mathrm{g} / \mathrm{L}$ & NWQL \\
\hline Prometon, water, filtered, recoverable & 04037 & .01 & $\mu \mathrm{g} / \mathrm{L}$ & NWQL \\
\hline Prometryn, water, filtered, recoverable & 04036 & .0059 & $\mu \mathrm{g} / \mathrm{L}$ & NWQL \\
\hline Propyzamide, water, filtered (0.7-micron glass fiber filter), recoverable & 82676 & .004 & $\mu \mathrm{g} / \mathrm{L}$ & NWQL \\
\hline Simazine, water, filtered, recoverable & 04035 & .006 & $\mu \mathrm{g} / \mathrm{L}$ & NWQL \\
\hline Tebuthiuron, water, filtered (0.7-micron glass fiber filter), recoverable & 82670 & .016 & $\mu \mathrm{g} / \mathrm{L}$ & NWQL \\
\hline Terbufos oxygen analog sulfone, water, filtered, recoverable & 61674 & .045 & $\mu \mathrm{g} / \mathrm{L}$ & NWQL \\
\hline Terbufos, water, filtered (0.7-micron glass fiber filter), recoverable & 82675 & .012 & $\mu \mathrm{g} / \mathrm{L}$ & NWQL \\
\hline Terbuthylazine, water, filtered, recoverable & 04022 & .0083 & $\mu \mathrm{g} / \mathrm{L}$ & NWQL \\
\hline Dichlorvos, water, filtered, recoverable & 38775 & .013 & $\mu \mathrm{g} / \mathrm{L}$ & NWQL \\
\hline
\end{tabular}


Appendix 3. Water-quality properties and constituents, reporting levels, and analyzing laboratories—Continued.

Table 3-10. Wastewater method compound names, suspected endocrine disruptors, possible compound uses, and method report limits (Schedule 1433)

Analyzing laboratory: USGS-National Water Quality Laboratory, Denver, Colo. (NWOL)

[ $\mu \mathrm{g} / \mathrm{L}$, microgram per liter; \%, percent; >, greater than; PAH, polyaromatic hydrocarbon; UV, ultraviolet; bold compound names indicate known or suspected endocrine disruptors]

\begin{tabular}{|c|c|c|c|}
\hline Compound name & $\begin{array}{l}\text { Parameter } \\
\text { code }\end{array}$ & $\begin{array}{c}\text { Reporting } \\
\text { level } \\
\text { ( } \mu \mathrm{g} / \mathrm{L})\end{array}$ & Possible compound uses or sources \\
\hline Acetophenone & 62064 & 0.5 & Fragrance in detergent and tobacco, flavor in beverages, $\mathrm{PAH}$ \\
\hline $\begin{array}{l}\text { Acetyl hexamethyl tetrahydro } \\
\text { naphthalene (AHTN) }\end{array}$ & 62065 & .5 & $\begin{array}{l}\text { Musk fragrance, persistent and widespread in ground water, } \\
\text { concern for bioaccumulation and toxicity }\end{array}$ \\
\hline Anthracene & 34221 & .5 & $\begin{array}{l}\text { Wood preservative, component of tar, diesel, or crude oil, } \\
\text { combustion product, PAH }\end{array}$ \\
\hline 9,10-Anthraquinone & 62066 & .5 & Manufacturing dye/textiles, seed treatment, bird repellant \\
\hline Benzo $[a]$ pyrene & 34248 & .5 & Regulated PAH, used in cancer research, combustion product \\
\hline Benzophenone & 62067 & .5 & Fixative for perfumes and soaps \\
\hline Bisphenol A & 62069 & 1 & Manufacturing polycarbonate resins, antioxidant, flame retardant \\
\hline Bromacil & 04029 & .5 & Herbicide (general use pesticide), $>80 \%$ noncrop use on grass/brush \\
\hline 3-tert-Butyl-4-hydroxyanisole (BHA) & 62059 & 5 & Antioxidant, general preservative \\
\hline Caffeine & 50305 & .5 & Beverages, diuretic, very mobile/biodegradable \\
\hline Camphor & 62070 & .5 & Flavor, odorant, ointments \\
\hline Carbaryl & 82680 & 1 & Insecticide, crop and garden uses, low persistence \\
\hline Carbazole & 62071 & .5 & Insecticide, manufacturing dyes, explosives, and lubricants \\
\hline Chlorpyrifos & 38933 & $\begin{array}{l}.005, \\
.007, \\
.008, \\
.009, \\
.011, \\
.012, \\
.013, \\
.015, \\
.016, \\
.022, \\
.026, \\
.028, \\
.5\end{array}$ & $\begin{array}{l}\text { Insecticide, domestic pest and termite control (domestic use } \\
\text { restricted as of 2001) }\end{array}$ \\
\hline Cholesterol & 62072 & 2 & Often a fecal indicator, also a plant sterol \\
\hline 3-beta-Coprostanol & 62057 & 2 & Carnivore fecal indicator \\
\hline Cotinine & 62005 & 1 & Primary nicotine metabolite \\
\hline 4-Cumylphenol & 62060 & 1 & Nonionic detergent metabolite \\
\hline Diazinon & 39572 & $\begin{array}{l}.005 \\
.012 \\
.017 \\
.5\end{array}$ & Insecticide, $>40 \%$ nonagricultural use, ants, flies \\
\hline 1,4-Dichlorobenzene & 34572 & 0.5 & Moth repellant, fumigant, deodorant \\
\hline Dichlorvos & 38775 & $1^{.01}$ & Insecticide, pet collars, flies, also a degradate of naled or trichlofon \\
\hline Diethoxynonylphenol (NPEO2) & 62083 & 5 & Nonionic detergent metabolite \\
\hline
\end{tabular}


Appendix 3. Water-quality properties and constituents, reporting levels, and analyzing laboratories—Continued.

Table 3-10. Wastewater method compound names, suspected endocrine disruptors, possible compound uses, and method report limits (Schedule 1433)-Continued

Analyzing laboratory: USGS-National Water Quality Laboratory, Denver, Colo. (NWQL)

$[\mu \mathrm{g} / \mathrm{L}$, microgram per liter; \%, percent; >, greater than; PAH, polyaromatic hydrocarbon; UV, ultraviolet; bold compound names indicate known or suspected endocrine disruptors]

\begin{tabular}{|c|c|c|c|}
\hline Compound name & $\begin{array}{l}\text { Parameter } \\
\text { code }\end{array}$ & $\begin{array}{c}\text { Reporting } \\
\text { level } \\
(\mu \mathrm{g} / \mathrm{L})\end{array}$ & Possible compound uses or sources \\
\hline Diethoxyoctylphenol (OPEO2) & 61705 & 1 & Nonionic detergent metabolite \\
\hline $\begin{array}{l}\text { Ethoxyoctylphenol (OPEO1, } \\
\text { monoethoxyoctylphenol) }\end{array}$ & 61706 & 1 & Nonionic detergent metabolite \\
\hline 2,6-Dimethylnaphthalene & 62055 & 0.5 & Present in diesel/kerosene (trace in gasoline) \\
\hline Fluoranthene & 34377 & .5 & $\begin{array}{l}\text { Component of coal tar and asphalt (only traces in gasoline or diesel } \\
\text { fuel), combustion product, PAH }\end{array}$ \\
\hline $\begin{array}{l}\text { Hexahydrohexamethyl- } \\
\text { cyclopentabenzopyran (HHCB) }\end{array}$ & 62075 & .5 & $\begin{array}{l}\text { Musk fragrance, persistent and widespread, in ground water, } \\
\text { concern for bioaccumulation and toxixity }\end{array}$ \\
\hline Indole & 62076 & .5 & Pesticide inert ingredient, fragrance in coffee \\
\hline Isoborneol & 62077 & .5 & Fragrance in perfumery, in disinfectants \\
\hline Isophorone & 34409 & .5 & Solvent for lacquer, plastic, oil, silicon, resin \\
\hline Isopropylbenzene (cumene) & 62078 & .5 & Manufacturing phenol/acetone, fuels and paint thinner \\
\hline Isoquinoline & 62079 & .5 & Flavors and fragrances \\
\hline$d$-Limonene & 62073 & .5 & Fungicide, antimicrobial, antiviral, fragrance in aerosols \\
\hline Menthol & 62080 & .5 & Cigarettes, cough drops, liniment, mouthwash \\
\hline Metalaxyl & 50359 & .5 & $\begin{array}{l}\text { Herbicide, fungicide (general use pesticide), mildew, blight, } \\
\text { pathogens, golf courses/turf }\end{array}$ \\
\hline 5-Methyl-1H-benzotriazole & 62063 & 2 & Antioxidant in antifreeze and deicers \\
\hline 3-Methyl-1H-indole (skatol) & 62058 & 1 & Fragrance, stench in feces and coal tar \\
\hline 1-Methylnaphthalene & 62054 & .5 & $2-5 \%$ of gasoline, diesel fuel, or crude oil \\
\hline 2-Methylnaphthalene & 62056 & .5 & $2-5 \%$ of gasoline, diesel fuel, or crude oil, $\mathrm{PAH}$ \\
\hline Methyl salicylate & 62081 & .5 & Liniment, food, beverage, UV-absorbing lotion \\
\hline Metolachlor & 39415 & .5 & Herbicide (general use pesticide), indicator of agricultural drainage \\
\hline N,N-diethyl-meta-toluamide (DEET) & 62082 & .5 & Insecticide, urban uses, mosquito repellent \\
\hline Naphthalene & 34443 & .5 & $\begin{array}{l}\text { Fumigant, moth repellent, major component (about 10\%) of } \\
\text { gasoline, PAH }\end{array}$ \\
\hline $\begin{array}{l}\text { 4-Nonylphenol, total } \\
\text { (para-Nonylphenol, NP) }\end{array}$ & 62085 & 5 & Nonionic detergent metabolite \\
\hline 4-Octylphenol (4-normal-Octylphenol) & 62061 & 1 & Nonionic detergent metabolite \\
\hline 4-tert-Octylphenol & 62062 & 1 & Nonionic detergent metabolite \\
\hline p-Cresol (para-Cresol) & 62084 & 1 & Wood preservative \\
\hline Pentachlorophenol & 34459 & 2 & Herbicide, fungicide, wood preservative, termite control \\
\hline Phenanthrene & 34462 & .5 & $\begin{array}{l}\text { Manufacturing explosives, component of tar, diesel fuel, or crude } \\
\text { oil, combustion product, PAH }\end{array}$ \\
\hline Phenol & 34466 & .5 & Disinfectant, manufufacturing several products, leachate \\
\hline
\end{tabular}


Appendix 3. Water-quality properties and constituents, reporting levels, and analyzing laboratories—Continued.

Table 3-10. Wastewater method compound names, suspected endocrine disruptors, possible compound uses, and method report limits (Schedule 1433) - Continued

Analyzing laboratory: USGS-National Water Quality Laboratory, Denver, Colo. (NWOL)

[ $\mu \mathrm{g} / \mathrm{L}$, microgram per liter; \%, percent; >, greater than; PAH, polyaromatic hydrocarbon; UV, ultraviolet; bold compound names indicate known or suspected endocrine disruptors]

\begin{tabular}{|c|c|c|c|}
\hline Compound name & $\begin{array}{l}\text { Parameter } \\
\text { code }\end{array}$ & $\begin{array}{c}\text { Reporting } \\
\text { level } \\
(\mu \mathrm{g} / \mathrm{L})\end{array}$ & Possible compound uses or sources \\
\hline Prometon & 04037 & .5 & Herbicide (noncrop only), applied prior to blacktop \\
\hline Pyrene & 34470 & .5 & $\begin{array}{l}\text { Component of coal tar and asphalt (only traces in gasoline or } \\
\text { diesel fuel), combustion product, PAH }\end{array}$ \\
\hline beta-Sitosterol & 62068 & $\begin{array}{c}2 \\
20\end{array}$ & Plant sterol \\
\hline beta-Stigmastanol & 62086 & $\begin{array}{c}2, \\
20\end{array}$ & Plant sterol \\
\hline Tetrachloroethylene (TCE) & 34476 & 0.5 & Solvent, degreaser, veterinary anthelmintic \\
\hline Tribromomethane (bromoform) & 34288 & .5 & Wastewater ozination byproduct, military/explosives \\
\hline Tributyl phosphate & 62089 & .5 & Antifoaming agent, flame retardant \\
\hline Triclosan & 62090 & 1 & $\begin{array}{l}\text { Disinfectant, antimicrobial (concern for acquired microbial } \\
\text { resistance) }\end{array}$ \\
\hline Triethyl citrate (ethyl citrate) & 62091 & .5 & Cosmetics, pharmaceuticals \\
\hline Triphenyl phosphate & 62092 & .5 & Plasticizer, resin, wax, finish, roofing paper, flame retardant \\
\hline Tris(2-butoxyethyl) phosphate & 62093 & .5 & Flame retardant \\
\hline $\begin{array}{l}\text { Tris(2-chloroethyl) phosphate } \\
\text { (Fyrol CEF) }\end{array}$ & 62087 & .5 & Plasticizer, flame retardant \\
\hline $\begin{array}{l}\text { Tris(dichloroisopropyl) phosphate } \\
\text { (Fyrol FR 2) }\end{array}$ & 62088 & .5 & Flame retardant \\
\hline
\end{tabular}


Appendix 3. Water-quality properties and constituents, reporting levels, and analyzing laboratories—Continued.

Table 3-11. Analyses performed on semipermeable membrane device (SPMD) extracts Analyzing laboratories: U.S. Army Corps of Engineers, Vicksburg, Miss.; USGS-Columbia Environmental Research Center, Columbia, Mo. (CERC); USGS-National Water Quality Laboratory, Denver, Colo. (NWOL)

[--, not available; pg TEQ/mL SPMD, picograms of 2,3,7,8-tetrachlorodibenzo- $p$-dioxin per milliliter of SPMD extract; $\mu \mathrm{g}$ PAH/mL SPMD, micrograms of polycyclic aromatic hydrocarbons per milliliter of SPMD extract; mg eq SPMD/mL DSMO, milligram equivalent SPDM extract per milliliter dimethyl sulfoxide; ng/SPMD, nanograms per total SPMD; units for Microtox EC50 are for the 50-percent effective concentration]

\begin{tabular}{|c|c|c|c|c|}
\hline Constituent & $\begin{array}{c}\text { Parameter } \\
\text { code }\end{array}$ & $\begin{array}{c}\text { Reporting } \\
\text { level }\end{array}$ & Reporting units & Analyzing lab \\
\hline Cytochrome P450RGS & -- & -- & pg TEQ/mL SPMD & U.S. Army Corps of Engineers \\
\hline Fluoroscan & -- & -- & ug PAH/mL SPMD & CERC \\
\hline Microtox EC50 & -- & -- & mg eq SPMD/mL DSMO & CERC \\
\hline Anthracene & -- & 100 & ng/SPMD & NWQL \\
\hline Fluoranthene & -- & 50 & ng/SPMD & NWQL \\
\hline Fluorene & -- & 1 & ng/SPMD & NWQL \\
\hline Naphthalene & -- & 25 & ng/SPMD & NWQL \\
\hline 1-Methylnaphthalene & -- & 25 & ng/SPMD & NWQL \\
\hline 2-Methylnaphthalene & -- & 38.4 & ng/SPMD & NWQL \\
\hline 2,6-Dimethylnaphthalene & -- & 25 & ng/SPMD & NWQL \\
\hline Phenanthrene & -- & 50 & ng/SPMD & NWQL \\
\hline Pyrene & -- & 50 & ng/SPMD & NWQL \\
\hline Methyl pyrene & -- & 1 & ng/SPMD & NWQL \\
\hline Benzo[a]pyrene & -- & 50 & ng/SPMD & NWQL \\
\hline
\end{tabular}


Appendix 3. Water-quality properties and constituents, reporting levels, and analyzing laboratories—Continued.

Table 3-12. Analyses performed on bed sediment Analyzing laboratory: Wisconsin State Lab of Hygiene, Madison, Wis. (WSLH); University of Wisconsin Extension Soil and Plant Analysis Laborator, Madison, Wis. (UWE-SPAL)

[mg/kg, milligram per kilogram; $\mu \mathrm{g} / \mathrm{g}$, microgram per gram; --, not available]

\begin{tabular}{lcccc}
\hline \multicolumn{1}{c}{ Constituent } & $\begin{array}{c}\text { Parameter } \\
\text { code }\end{array}$ & $\begin{array}{c}\text { Reporting } \\
\text { level }\end{array}$ & Reporting units & Analyzing lab \\
\hline Sand & -- & -- & -- & UWE-SPAL \\
Silt & -- & -- & -- & UWE-SPAL \\
Clay & -- & -- & -- & UWE-SPAL \\
Arsenic in sediment & -- & 1 & $\mathrm{mg} / \mathrm{kg}$ & WSLH \\
Cadmium in sediment & -- & .1 & $\mathrm{mg} / \mathrm{kg}$ & WSLH \\
Chromium in sediment & -- & .5 & $\mathrm{mg} / \mathrm{kg}$ & WSLH \\
Copper in sediment & -- & .5 & $\mathrm{mg} / \mathrm{kg}$ & WSLH \\
Lead in sediment & -- & 1 & $\mathrm{mg} / \mathrm{kg}$ & WSLH \\
Mercury in sediment & -- & .015 & $\mathrm{mg} / \mathrm{kg}$ & WSLH \\
Nickel in sediment & -- & .5 & $\mathrm{mg} / \mathrm{kg}$ & WSLH \\
Total phosphorus in sediment & -- & 9.9 & $\mathrm{mg} / \mathrm{kg}$ & WSLH \\
Zinc in sediment & -- & .5 & $\mathrm{mg} / \mathrm{kg}$ & WSLH \\
Total PCBs in sediment & -- & .024 & $\mu \mathrm{g} / \mathrm{g}$ & WSLH \\
Total organic carbon in sediment & -- & 2,270 & $\mu \mathrm{m} / \mathrm{g}$ & WSLH \\
\hline
\end{tabular}


Appendix 3. Water-quality properties and constituents, reporting levels, and analyzing laboratories—Continued.

Table 3-13. Analyses performed on fish tissues Analyzing laboratory: Wisconsin State Lab of Hygiene, Madison, Wis. (WSLH)

[\%, percent; $\mu \mathrm{g} / \mathrm{g}$, microgram per gram; ww, wet weight; --, not available]

\begin{tabular}{lcccc}
\hline \multicolumn{1}{c}{ Constituent } & $\begin{array}{c}\text { Parameter } \\
\text { code }\end{array}$ & $\begin{array}{c}\text { Reporting } \\
\text { level }\end{array}$ & Reporting units & Analyzing lab \\
\hline Water present, biota, tissue, recoverable & 49273 & -- & $\%$ of water present & WSLH \\
Chromium, biota, tissue, recoverable & 63797 & 0.2 & $\mu \mathrm{g} / \mathrm{g} \mathrm{ww}$ & $\mathrm{WSLH}$ \\
Copper, biota, tissue, recoverable & 63799 & .06 & $\mu \mathrm{g} / \mathrm{g} \mathrm{ww}$ & $\mathrm{WSLH}$ \\
Lead, biota, tissue, recoverable & 63800 & .8 & $\mu \mathrm{g} / \mathrm{g} \mathrm{ww}$ & $\mathrm{WSLH}$ \\
Mercury, biota, tissue, recoverable & 63792 & .004 & $\mu \mathrm{g} / \mathrm{g} \mathrm{ww}$ & $\mathrm{WSLH}$ \\
Lipids, biota, whole organism, recoverable & 49289 & -- & $\% \mathrm{ww}$ & $\mathrm{WSLH}$ \\
p,p'-DDE, biota, whole organism, recoverable & 49372 & .01 & $\mu \mathrm{g} / \mathrm{g} \mathrm{ww}$ & $\mathrm{WSLH}$ \\
p,p'-DDT, biota, whole organism, recoverable & 49376 & .01 & $\mu \mathrm{g} / \mathrm{g} \mathrm{ww}$ & $\mathrm{WSLH}$ \\
p,p'-DDD, biota, whole organism, recoverable & 49375 & .01 & $\mu \mathrm{g} / \mathrm{g} \mathrm{ww}$ & $\mathrm{WSLH}$ \\
PCBs, biota, whole organism, recoverable & 49354 & .04 & $\mu \mathrm{g} / \mathrm{g} \mathrm{ww}$ & $\mathrm{WSLH}$ \\
\multicolumn{1}{c}{ Araclor-1261 } & -- & .04 & $\mu \mathrm{g} / \mathrm{g} \mathrm{ww}$ & $\mathrm{WSLH}$ \\
Araclor-1248/1254/1261 & -- & .04 & $\mu \mathrm{g} / \mathrm{g} \mathrm{ww}$ & WSLH \\
\hline
\end{tabular}


Appendix 3. Water-quality properties and constituents, reporting levels, and analyzing laboratories—Continued.

Table 3-14. Bioassessment

Analyzing laboratories: University of Wisconsin-Stevens Point Aquatic Entomology Laboratory, Stevens Point, Wis. (UW-SP); USGS-National Water Quality Laboratory, Denver, Colo. (NWQL); Academy of Natural Sciences, Philadelphia, Pa.

[ $\mathrm{cm}^{2}$, square centimeter; --, not available]

\begin{tabular}{lcccl}
\hline \multicolumn{1}{c}{ Constituent } & $\begin{array}{c}\text { Parameter } \\
\text { code }\end{array}$ & $\begin{array}{c}\text { Reporting } \\
\text { level }\end{array}$ & Reporting units & Analyzing lab \\
\hline Fish & -- & -- & number of individuals/taxon & None (field) \\
Macroinvertebrates & -- & -- & number of individuals/taxon & $\begin{array}{c}\text { UW-SP (samples from Little Menomonee } \\
\text { River at Milwaukee and Honey Creek at }\end{array}$ \\
& & & Wauwatosa analyzed by NWQL) \\
Algae & -- & -- & number of cells/taxon/cm ${ }^{2}$ & Academy of Natural Sciences \\
Habitat & -- & -- & various & None (field) \\
\hline
\end{tabular}


七|

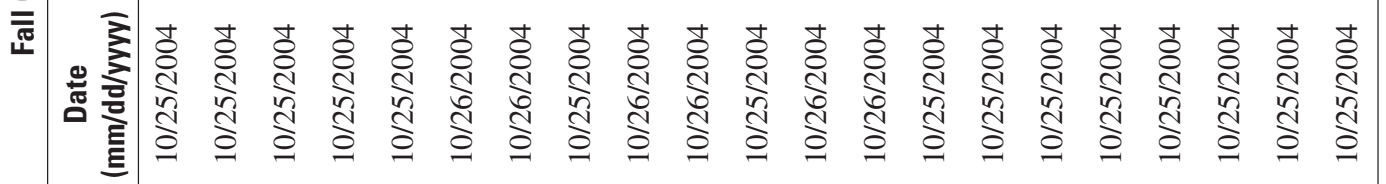

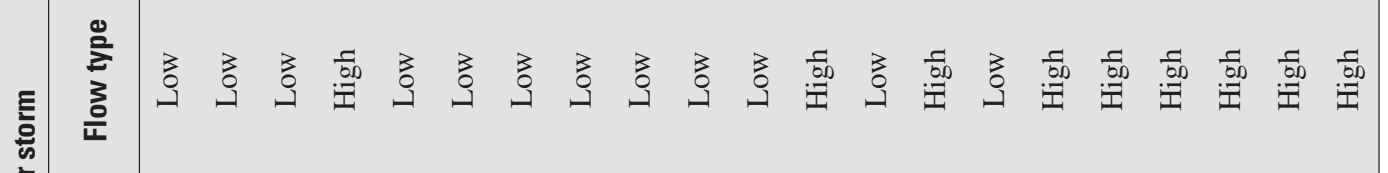

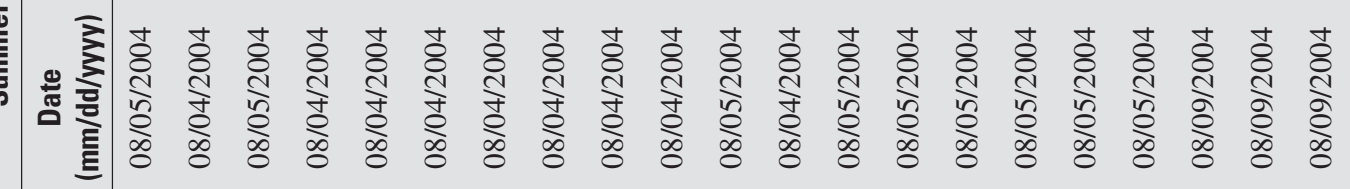
七

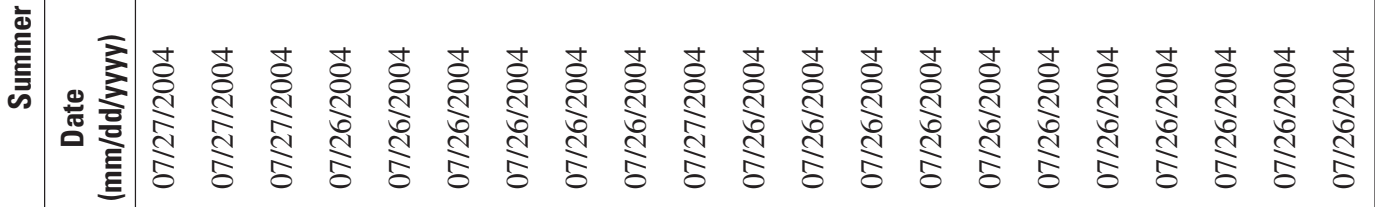
悹

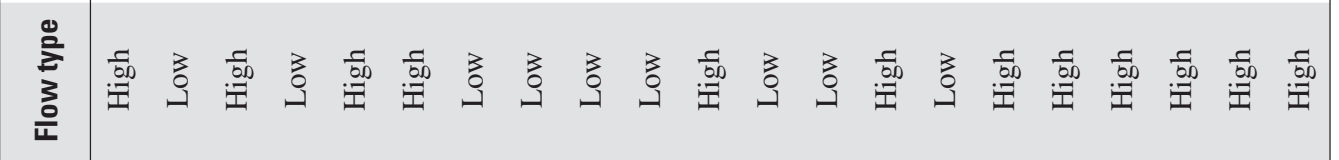
ప

के

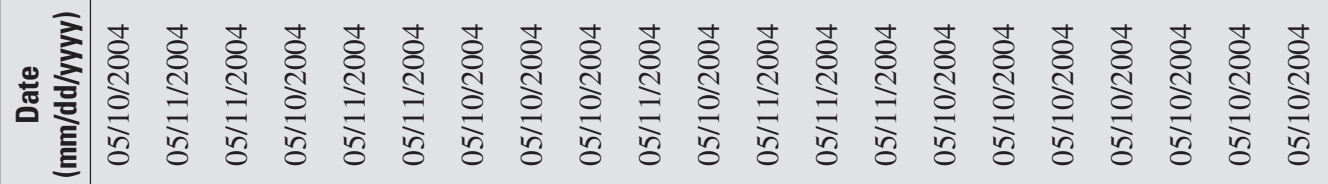
ลิ

혿 


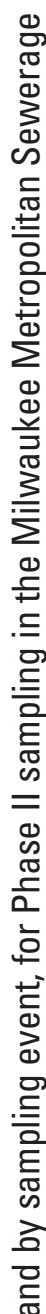

占

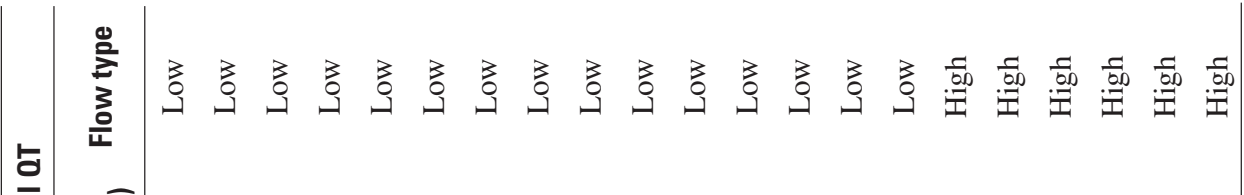

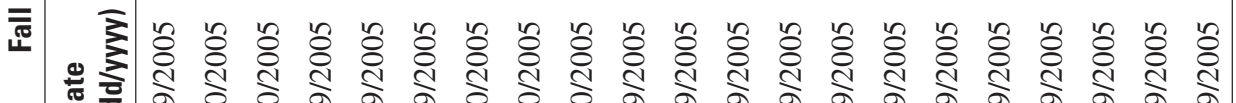

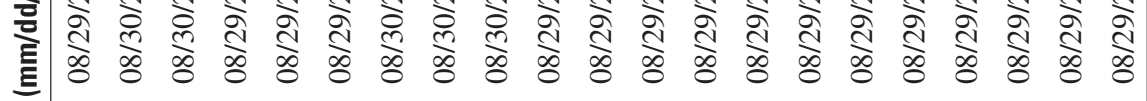

을

ह

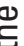

产

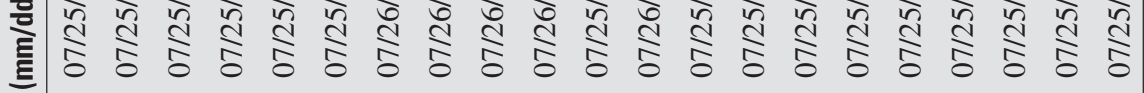

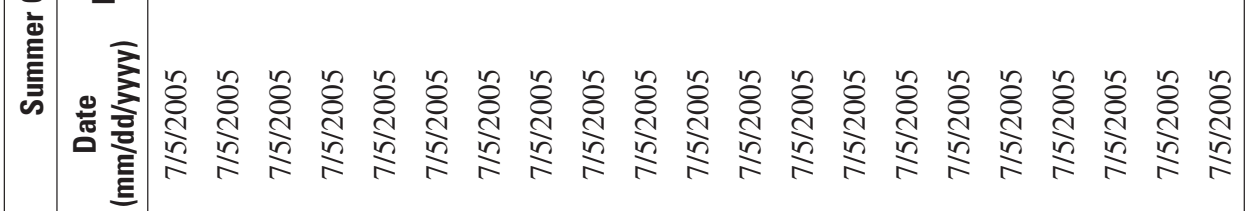

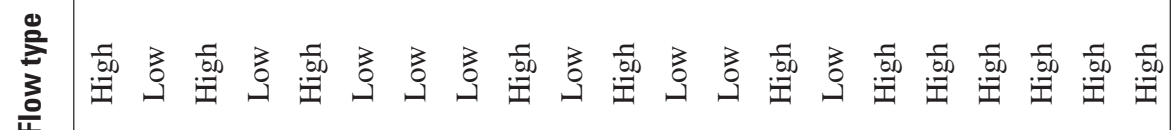

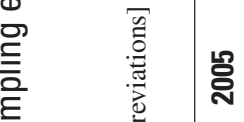

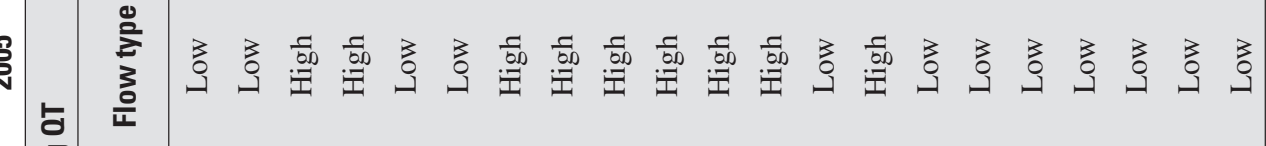

효

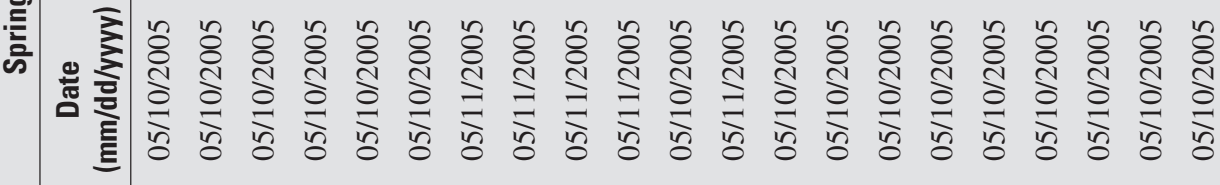

วิ.

ले

旁

总

$\pm$

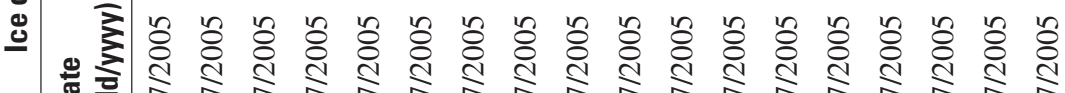

은 일

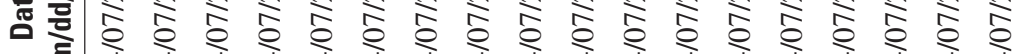

它

동

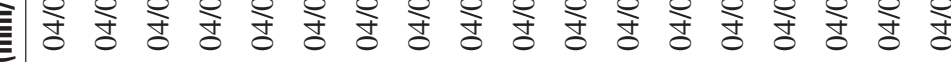

๖

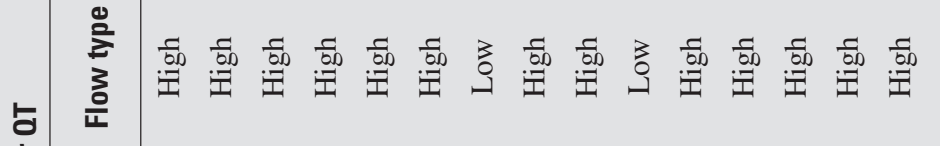

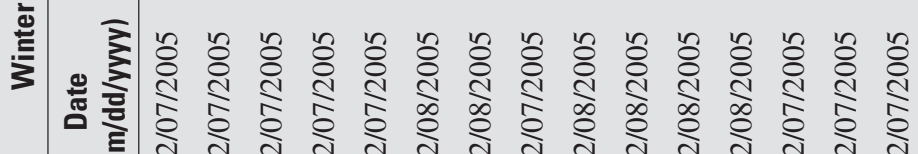

$x \sum$ 可

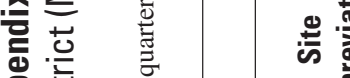

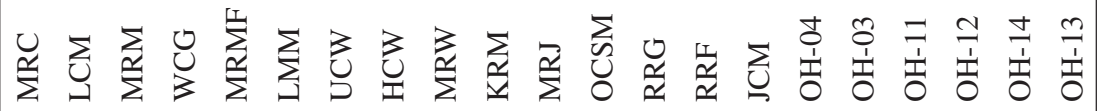


Appendix 5. Comparison of median constituent concentrations and detections between Phase I and Phase II of the MMSD Corridor Study

[mg/L, milligram per liter; mg/m³, milligram per cubic meter; CFU/100ml, colony-forming unit per 100 milliliters; $\mu \mathrm{g} / \mathrm{g}$, microgram per gram; mg/kg, milligram per kilogram; PCB, polychlorinated biphenyl; EPT, Ephemeroptera, Plecoptera, and Trichoptera; HBI, Hilsenhoff Biotic Index; $\mu \mathrm{g} / \mathrm{L}$, microgram per liter; --, no data; RL, concentrations were below reporting level; *, fewer than 50 individual fish were collected, so the Wisconsin warmwater Index of Biotic Integrity should not be used (Lyons, 1992)]

\begin{tabular}{|c|c|c|c|}
\hline Phase I & \multicolumn{3}{|l|}{ Phase II } \\
\hline Subwatersheds & Site name & $\begin{array}{c}\text { Site } \\
\text { number }\end{array}$ & $\begin{array}{c}\text { Site } \\
\text { abbreviation }\end{array}$ \\
\hline \multicolumn{4}{|l|}{ Fox River Watershed } \\
\hline Muskego Lake & Jewel Creek at Muskego & 05544371 & $\mathrm{JCM}$ \\
\hline \multicolumn{4}{|c|}{ Kinnickinnic River Watershed } \\
\hline Kinnickinnic River & Kinnickinnic River at S. 11th Street at Milwaukee & 04087159 & KRM \\
\hline \multicolumn{4}{|c|}{ Menomonee River Watershed } \\
\hline Honey Creek & Honey Creek at Wauwatosa & 04087119 & $\mathrm{HCW}$ \\
\hline Little Menomonee River & Little Menomonee River at Milwaukee & 04087070 & LMM \\
\hline Lower Menomonee River & Menomonee River at Wauwatosa & 04087120 & MRW \\
\hline Upper Menomonee River & Menomonee River at Menomonee Falls & 04087030 & MRMF \\
\hline Underwood Creek & Underwood Creek at Wauwatosa & 04087088 & UCW \\
\hline Willow Creek & Willow Creek at Maple Road near Germantown & 040870195 & WCG \\
\hline \multicolumn{4}{|l|}{ Milwaukee River Watershed } \\
\hline Lincoln Creek & Lincoln Creek at 47th Street at Milwaukee & 040869415 & LCM \\
\hline \multirow[t]{3}{*}{ Lower Milwaukee River ${ }^{1}$} & Milwaukee River near Cedarburg ${ }^{1}$ & 04086600 & $\mathrm{MRC}^{1}$ \\
\hline & Milwaukee River at Milwaukee $^{1}$ & 04087000 & $\mathrm{MRM}^{1}$ \\
\hline & Milwaukee River at Mouth at Milwaukee ${ }^{1}$ & 04087170 & $\mathrm{MRJ}^{1}$ \\
\hline \multicolumn{4}{|l|}{ Oak Creek Watershed } \\
\hline Lower Oak Creek & Oak Creek at South Milwaukee & 04087204 & OCSM \\
\hline \multicolumn{4}{|l|}{ Root River Watershed } \\
\hline Middle Root River & Root River near Franklin & 04087220 & RRF \\
\hline Upper Root River & Root River at Grange Avenue at Greenfield & 04087214 & RRG \\
\hline
\end{tabular}

${ }^{1}$ Three of the Phase II sites sampled were in the Lower Milwaukee River Subwatershed. Comparisons could be drawn individually between each site and the Phase I subwatershed; however, for the discussion in the text, these three sites were not considered adequately representative of that subwatershed due to their location and the size and complexity of the subwatershed. Comparisons of these sites to the subwatershed were omitted when discussing overall trends between Phase I and Phase II data in the text; however, contamination of this subwatershed with synthetic organic contaminants (especially PCBs) was well documented and was discussed in general terms using the data from the Milwaukee River at Milwaukee site.

${ }^{2}$ Values given as median concentrations.

${ }^{3}$ Phase I concentrations were originally published in micrograms per gram, which is equivalent to milligrams per kilogram.

${ }^{4}$ Values given as total number of fish species.

${ }^{5}$ Phase I values given as median IBI scores for 1990-2002. Phase II IBI scores were determined from a single community survey.

${ }^{6}$ Phase I values given as median percentages of EPT taxa. Phase II percentages of EPT taxa were determined from a single community survey.

${ }^{7}$ Phase I values given as median HBI values. Phase II HBI-10 values were determined from a single community survey. 


\begin{tabular}{|c|c|c|c|c|c|c|c|c|c|c|c|}
\hline \multicolumn{3}{|c|}{ Chloride } & \multicolumn{3}{|c|}{ Total nitrogen } & \multicolumn{3}{|c|}{ Nitrate } & \multicolumn{3}{|c|}{ Total phosphorus } \\
\hline $\begin{array}{c}\text { Phase } \mathrm{I}^{2} \\
\text { (mg/L) }\end{array}$ & $\begin{array}{c}\text { Phase } \|^{2} \\
\text { (mg/L) }\end{array}$ & $\begin{array}{c}\text { Percent } \\
\text { difference }\end{array}$ & $\begin{array}{c}\text { Phase } \mathrm{I}^{2} \\
(\mathrm{mg} / \mathrm{L})\end{array}$ & $\begin{array}{c}\text { Phase } I^{2} \\
\text { (mg/L) }\end{array}$ & $\begin{array}{c}\text { Percent } \\
\text { difference }\end{array}$ & $\begin{array}{c}\text { Phase } \mathrm{I}^{2} \\
\text { (mg/L) }\end{array}$ & $\begin{array}{c}\text { Phase } \|^{2} \\
\text { (mg/L) }\end{array}$ & $\begin{array}{c}\text { Percent } \\
\text { difference }\end{array}$ & $\begin{array}{c}\text { Phase } \mathrm{I}^{2} \\
\text { (mg/L) }\end{array}$ & $\begin{array}{c}\text { Phase II } \\
\text { (mg/L) }\end{array}$ & $\begin{array}{c}\text { Percent } \\
\text { difference }\end{array}$ \\
\hline-- & 136 & -- & 1.27 & 1.26 & -1 & 0.1 & 0.835 & 735 & 0.075 & 0.062 & -17 \\
\hline 54 & 210 & 289 & 1.39 & 1.14 & -18 & .47 & .460 & -2 & .07 & .148 & 111 \\
\hline-- & 260 & -- & .33 & 1.28 & 288 & .17 & .605 & 256 & .04 & .15 & 275 \\
\hline -- & 104 & -- & 3.32 & 1.43 & -57 & .01 & .545 & 5,350 & .01 & .152 & 1,420 \\
\hline 75 & 175 & 133 & 1.58 & 1.17 & -26 & .52 & .560 & 8 & .1 & .113 & 13 \\
\hline 90 & 138 & 53 & 1.56 & 1.04 & -33 & .64 & .370 & -42 & .09 & .1 & 11 \\
\hline -- & 295 & -- & -- & 1.17 & -- & RL & .410 & -- & -- & .085 & -- \\
\hline 50 & 107 & 114 & 1.85 & 1.38 & -25 & .78 & .860 & 10 & .067 & .068 & 1 \\
\hline 104 & 246 & 137 & 1.24 & .98 & -21 & .45 & .265 & -41 & .1 & .163 & 63 \\
\hline 42 & 75.9 & 81 & 1.68 & 2.14 & 27 & .59 & 1.40 & 137 & .1 & .120 & 20 \\
\hline & 91.9 & 119 & & 1.89 & 13 & & 1.17 & 98 & & .133 & 33 \\
\hline & 54.9 & 31 & & 1.22 & -27 & & .610 & 3 & & .061 & -39 \\
\hline 135 & 208 & 54 & 1.2 & 1.24 & 3 & .47 & .500 & 6 & .06 & .079 & 32 \\
\hline 135 & 144 & 7 & 1.19 & 1.28 & 8 & .14 & .545 & 289 & .061 & .092 & 51 \\
\hline 190 & 246 & 29 & 1.44 & 1.34 & -7 & .47 & .525 & 12 & .1 & .113 & 13 \\
\hline
\end{tabular}


Appendix 5. Comparison of median constituent concentrations and detections between Phase I and Phase II of the MMSD Corridor Study-Continued.

[mg/L, milligram per liter; mg/m³, milligram per cubic meter; CFU/100ml, colony-forming unit per 100 milliliters; $\mu \mathrm{g} / \mathrm{g}$, microgram per gram; mg/kg, milligram per kilogram; PCB, polychlorinated biphenyl; EPT, Ephemeroptera, Plecoptera, and Trichoptera; HBI, Hilsenhoff Biotic Index; $\mu \mathrm{g} / \mathrm{L}$, microgram per liter; --, no data; RL, concentrations were below reporting level; *, fewer than 50 individual fish were collected, so the Wisconsin warmwater Index of Biotic Integrity should not be used (Lyons, 1992)]

\begin{tabular}{|c|c|c|c|c|c|c|c|}
\hline Phase I & Phase II & \multicolumn{3}{|c|}{ Chlorophyll a } & \multicolumn{3}{|c|}{ Suspended sediment } \\
\hline Subwatersheds & $\begin{array}{c}\text { Site } \\
\text { abbreviation }\end{array}$ & $\begin{array}{l}\text { Phase } \mathrm{I}^{2} \\
\left(\mathrm{mg} / \mathrm{m}^{3}\right)\end{array}$ & $\begin{array}{c}\text { Phase II² } \\
\left(\mathrm{mg} / \mathrm{m}^{3}\right)\end{array}$ & $\begin{array}{c}\text { Percent } \\
\text { difference }\end{array}$ & $\begin{array}{c}\text { Phase } 1^{2} \\
\text { (mg/L) }\end{array}$ & $\begin{array}{c}\text { Phase II² } \\
\text { (mg/L) }\end{array}$ & $\begin{array}{c}\text { Percent } \\
\text { difference }\end{array}$ \\
\hline \multicolumn{8}{|l|}{ Fox River Watershed } \\
\hline Muskego Lake & $\mathrm{JCM}$ & -- & 10.3 & -- & 39 & 28 & -28 \\
\hline \multicolumn{8}{|c|}{ Kinnickinnic River Watershed } \\
\hline Kinnickinnic River & KRM & 4.62 & 5.06 & 10 & 356 & 12 & -97 \\
\hline \multicolumn{8}{|c|}{ Menomonee River Watershed } \\
\hline Honey Creek & $\mathrm{HCW}$ & -- & 6.76 & -- & 193 & 10 & -95 \\
\hline Little Menomonee River & LMM & -- & 5.96 & -- & 178 & 26 & -85 \\
\hline Lower Menomonee River & MRW & 5.99 & 7.80 & 30 & 127 & 14 & -89 \\
\hline Upper Menomonee River & MRMF & 5.67 & 8.45 & 49 & 40 & 10 & -75 \\
\hline Underwood Creek & UCW & -- & 5.34 & -- & 234 & 6.5 & -97 \\
\hline Willow Creek & WCG & -- & 2.66 & -- & -- & 18 & -- \\
\hline \multicolumn{8}{|l|}{ Milwaukee River Watershed } \\
\hline Lincoln Creek & LCM & 5.07 & 4.66 & -8 & 25 & 5.5 & -78 \\
\hline \multirow[t]{3}{*}{ Lower Milwaukee River ${ }^{1}$} & $\mathrm{MRC}^{1}$ & 11.7 & 13.4 & 15 & 28 & 11 & -61 \\
\hline & MRM $^{1}$ & & 10.2 & -13 & & 15 & -46 \\
\hline & $\mathrm{MRJ}^{1}$ & & 5.77 & -51 & & 4 & -86 \\
\hline \multicolumn{8}{|l|}{ Oak Creek Watershed } \\
\hline Lower Oak Creek & OCSM & 3.74 & 3.52 & -6 & 58 & 18 & -69 \\
\hline \multicolumn{8}{|l|}{ Root River Watershed } \\
\hline Middle Root River & RRF & 7.17 & 4.70 & -34 & 62 & 22 & -65 \\
\hline Upper Root River & RRG & 1.46 & 1.34 & -8 & 204 & 14 & -93 \\
\hline
\end{tabular}

${ }^{1}$ Three of the Phase II sites sampled were in the Lower Milwaukee River Subwatershed. Comparisons could be drawn individually between each site and the Phase I subwatershed; however, for the discussion in the text, these three sites were not considered adequately representative of that subwatershed due to their location and the size and complexity of the subwatershed. Comparisons of these sites to the subwatershed were omitted when discussing overall trends between Phase I and Phase II data in the text; however, contamination of this subwatershed with synthetic organic contaminants (especially PCBs) was well documented and was discussed in general terms using the data from the Milwaukee River at Milwaukee site.

${ }^{2}$ Values given as median concentrations.

${ }^{3}$ Phase I concentrations were originally published in micrograms per gram, which is equivalent to milligrams per kilogram.

${ }^{4}$ Values given as total number of fish species.

${ }^{5}$ Phase I values given as median IBI scores for 1990-2002. Phase II IBI scores were determined from a single community survey.

${ }^{6}$ Phase I values given as median percentages of EPT taxa. Phase II percentages of EPT taxa were determined from a single community survey.

${ }^{7}$ Phase I values given as median HBI values. Phase II HBI-10 values were determined from a single community survey. 


\begin{tabular}{|c|c|c|c|c|c|c|c|c|c|}
\hline \multicolumn{3}{|c|}{ Fecal coliform } & \multicolumn{3}{|c|}{ Escherichia coli } & \multicolumn{2}{|c|}{$\begin{array}{c}\text { Arsenic } \\
\text { in sediment } \\
(\mathrm{mg} / \mathrm{kg})\end{array}$} & \multicolumn{2}{|c|}{$\begin{array}{c}\text { Cadmium } \\
\text { in sediment }^{3} \\
(\mathrm{mg} / \mathrm{kg})\end{array}$} \\
\hline $\begin{array}{c}\text { Phase I² } \\
\text { (CFU/100mL) }\end{array}$ & $\begin{array}{c}\text { Phase II² } \\
\text { (CFU/100mL) }\end{array}$ & $\begin{array}{c}\text { Percent } \\
\text { difference }\end{array}$ & $\begin{array}{c}\text { Phase } I^{2} \\
\text { (CFU/100mL) }\end{array}$ & $\begin{array}{c}\text { Phase II² } \\
\text { (MPN/100mL) }\end{array}$ & $\begin{array}{c}\text { Percent } \\
\text { difference }\end{array}$ & Phase $\mathrm{I}^{2}$ & Phase $\|^{2}$ & Phase $\mathrm{I}^{2}$ & Phase II \\
\hline RL & 165 & -- & -- & 185 & -- & -- & 10 & 0.4 & RL \\
\hline 930 & 610 & -34 & 780 & 995 & 28 & 6.1 & 8.5 & 4.4 & 0.6 \\
\hline 16,650 & 1,900 & -89 & 2,400 & 2,000 & -17 & -- & 5.0 & -- & .7 \\
\hline -- & 620 & -- & -- & 820 & -- & 6 & 12.0 & 4 & .9 \\
\hline 2,300 & 575 & -75 & 915 & 725 & -21 & 7 & $\mathrm{RL}$ & 3.9 & 1.1 \\
\hline 430 & 305 & -29 & 300 & 355 & 18 & 4 & 6.0 & 2 & 1.0 \\
\hline 20,000 & 660 & -97 & -- & 805 & -- & -- & 6.0 & -- & RL \\
\hline-- & 695 & -- & -- & 750 & -- & -- & 7.5 & -- & .9 \\
\hline 1,500 & 575 & -62 & 1,300 & 840 & -35 & 4 & 5.0 & 2 & .8 \\
\hline 460 & 130 & -72 & 220 & 43.5 & -80 & 5.1 & 6.0 & 3 & 1.0 \\
\hline & 170 & -63 & & 215 & -2 & & 5.5 & & .7 \\
\hline & 55 & -88 & & 56.5 & -74 & & 12 & & 3.5 \\
\hline 750 & 505 & -33 & -- & 565 & -- & -- & 5.0 & -- & RL \\
\hline 230 & 240 & 4 & -- & 225 & -- & 2 & 9.0 & 1 & 1.5 \\
\hline 750 & 610 & -19 & -- & 770 & -- & -- & 8.0 & -- & 1.4 \\
\hline
\end{tabular}


Appendix 5. Comparison of median constituent concentrations and detections between Phase I and Phase II of the MMSD Corridor Study-Continued.

[mg/L, milligram per liter; mg/m³, milligram per cubic meter; CFU/100ml, colony-forming unit per 100 milliliters; $\mu \mathrm{g} / \mathrm{g}$, microgram per gram; mg/kg, milligram per kilogram; PCB, polychlorinated biphenyl; EPT, Ephemeroptera, Plecoptera, and Trichoptera; HBI, Hilsenhoff Biotic Index; $\mu \mathrm{g} / \mathrm{L}$, microgram per liter; --, no data; RL, concentrations were below reporting level; *, fewer than 50 individual fish were collected, so the Wisconsin warmwater Index of Biotic Integrity should not be used (Lyons, 1992)]

\begin{tabular}{|c|c|c|c|c|c|c|c|}
\hline \multirow{2}{*}{$\begin{array}{c}\text { Phase I } \\
\text { Subwatersheds }\end{array}$} & \multirow{2}{*}{$\begin{array}{c}\text { Phase II } \\
\text { Site } \\
\text { abbreviation }\end{array}$} & \multicolumn{2}{|c|}{$\begin{array}{l}\text { Chromium } \\
\text { in sediment }{ }^{3} \\
(\mathrm{mg} / \mathrm{kg})\end{array}$} & \multicolumn{2}{|c|}{$\begin{array}{c}\text { Copper } \\
\text { in sediment }{ }^{3} \\
(\mathrm{mg} / \mathrm{kg})\end{array}$} & \multicolumn{2}{|c|}{$\begin{array}{c}\text { Lead } \\
\text { in sediment }{ }^{3} \\
(\mathrm{mg} / \mathrm{kg})\end{array}$} \\
\hline & & Phase $\mathrm{I}^{2}$ & Phase $\|^{2}$ & Phase $\mathrm{I}^{2}$ & Phase II $^{2}$ & Phase $\mathrm{I}^{2}$ & Phase II $^{2}$ \\
\hline \multicolumn{8}{|l|}{ Fox River Watershed } \\
\hline Muskego Lake & $\mathrm{JCM}$ & -- & 15 & -- & 27 & 6.5 & 19 \\
\hline \multicolumn{8}{|c|}{ Kinnickinnic River Watershed } \\
\hline Kinnickinnic River & KRM & 330 & 23 & 74.5 & 82 & 271 & 54 \\
\hline \multicolumn{8}{|l|}{ Menomonee River Watershed } \\
\hline Honey Creek & $\mathrm{HCW}$ & -- & 29 & -- & 57 & 4,100 & 39 \\
\hline Little Menomonee River & LMM & 70 & 19 & 140 & 38 & 260 & 38 \\
\hline Lower Menomonee River & MRW & 162 & 8.1 & 140 & 9.0 & 225 & 44 \\
\hline Upper Menomonee River & MRMF & 30 & 15 & 37 & 17 & 45 & 32 \\
\hline Underwood Creek & UCW & -- & 24 & -- & 29 & -- & 120 \\
\hline Willow Creek & WCG & -- & 11 & -- & 20 & -- & 13 \\
\hline \multicolumn{8}{|l|}{ Milwaukee River Watershed } \\
\hline Lincoln Creek & LCM & 20 & 17 & 39 & 36 & 80 & 28 \\
\hline \multirow[t]{3}{*}{ Lower Milwaukee River ${ }^{1}$} & $\mathrm{MRC}^{1}$ & 117 & 9.3 & 69 & 13 & 150 & 13 \\
\hline & $\mathrm{MRM}^{1}$ & & 16 & & 17 & & 43 \\
\hline & $\mathrm{MRJ}^{1}$ & & 94 & & 73 & & 89 \\
\hline \multicolumn{8}{|l|}{ Oak Creek Watershed } \\
\hline Lower Oak Creek & OCSM & -- & 12 & -- & 15 & -- & 12 \\
\hline \multicolumn{8}{|l|}{ Root River Watershed } \\
\hline Middle Root River & RRF & 8 & 12 & -- & 15 & 30 & 10 \\
\hline Upper Root River & RRG & -- & 13 & -- & 24 & -- & 25 \\
\hline
\end{tabular}

${ }^{1}$ Three of the Phase II sites sampled were in the Lower Milwaukee River Subwatershed. Comparisons could be drawn individually between each site and the Phase I subwatershed; however, for the discussion in the text, these three sites were not considered adequately representative of that subwatershed due to their location and the size and complexity of the subwatershed. Comparisons of these sites to the subwatershed were omitted when discussing overall trends between Phase I and Phase II data in the text; however, contamination of this subwatershed with synthetic organic contaminants (especially PCBs) was well documented and was discussed in general terms using the data from the Milwaukee River at Milwaukee site.

${ }^{2}$ Values given as median concentrations.

${ }^{3}$ Phase I concentrations were originally published in micrograms per gram, which is equivalent to milligrams per kilogram.

${ }^{4}$ Values given as total number of fish species.

${ }^{5}$ Phase I values given as median IBI scores for 1990-2002. Phase II IBI scores were determined from a single community survey.

${ }^{6} \mathrm{Phase}$ I values given as median percentages of EPT taxa. Phase II percentages of EPT taxa were determined from a single community survey.

${ }^{7}$ Phase I values given as median HBI values. Phase II HBI-10 values were determined from a single community survey. 


\begin{tabular}{|c|c|c|c|c|c|c|c|c|c|c|}
\hline \multicolumn{2}{|c|}{$\begin{array}{c}\text { Mercury } \\
\text { in sediment }^{3} \\
(\mathrm{mg} / \mathrm{kg})\end{array}$} & \multicolumn{2}{|c|}{$\begin{array}{c}\text { Nickel } \\
\text { in sediment }{ }^{3} \\
(\mathrm{mg} / \mathrm{kg})\end{array}$} & \multicolumn{2}{|c|}{$\begin{array}{c}\text { Zinc } \\
\text { in sediment }{ }^{3} \\
(\mathrm{mg} / \mathrm{kg})\end{array}$} & \multicolumn{4}{|c|}{ Phase I PCBs in sediment } & \multirow{2}{*}{$\begin{array}{c}\text { Phase II } \\
\text { total PCBs } \\
\text { in sediment }{ }^{2} \\
(\mathrm{mg} / \mathrm{kg})\end{array}$} \\
\hline Phase $\mathrm{I}^{2}$ & Phase II $^{2}$ & Phase $\mathrm{I}^{2}$ & Phase II $^{2}$ & Phase $\mathrm{I}^{2}$ & Phase $\|^{2}$ & $\begin{array}{c}\text { Total } \\
\text { number } \\
\text { of results }\end{array}$ & $\begin{array}{l}\text { Number } \\
\text { of results } \\
\text { below RL }\end{array}$ & $\begin{array}{c}\text { Number of } \\
\text { results at } \\
\text { or above RL }\end{array}$ & $\begin{array}{c}\text { Percent of } \\
\text { results at } \\
\text { or above } R \mathbf{L}\end{array}$ & \\
\hline-- & 0.06 & -- & 18 & -- & 95 & -- & -- & -- & -- & 0.02 \\
\hline 0.2 & .52 & 30 & 18 & 540 & 430 & 1,705 & 77 & 1,628 & 95 & -- \\
\hline-- & .04 & -- & 10 & -- & 180 & -- & -- & -- & -- & .04 \\
\hline .2 & .07 & 40 & 16 & 540 & 190 & 1 & 1 & 0 & 0 & .06 \\
\hline .46 & .03 & 29 & 6.0 & 503 & 39 & 179 & 104 & 75 & 42 & .12 \\
\hline .12 & .04 & 20 & 10 & 140 & 78 & 6 & 4 & 2 & 33 & .02 \\
\hline-- & .03 & -- & 10 & -- & 150 & -- & -- & -- & -- & .04 \\
\hline-- & .06 & -- & 11 & -- & 76 & -- & -- & -- & -- & .03 \\
\hline .07 & .06 & 30 & 10 & 160 & 150 & 12 & 6 & 6 & 50 & .03 \\
\hline .27 & .08 & 23 & 7.0 & 318 & 53 & 2,968 & 204 & 2,764 & 93 & .28 \\
\hline & .04 & & 9.0 & & 92 & & & & & 1.0 \\
\hline & .29 & & 20 & & 260 & & & & & 1.1 \\
\hline-- & .02 & -- & 6.0 & -- & 42 & -- & -- & -- & -- & .03 \\
\hline .02 & .05 & -- & 14 & 52 & 54 & -- & -- & -- & -- & RL \\
\hline -- & .04 & -- & 9.0 & -- & 87 & -- & -- & -- & -- & .05 \\
\hline
\end{tabular}


Appendix 5. Comparison of median constituent concentrations and detections between Phase I and Phase II of the MMSD Corridor Study-Continued.

[mg/L, milligram per liter; mg/m³, milligram per cubic meter; CFU/100ml, colony-forming unit per 100 milliliters; $\mu \mathrm{g} / \mathrm{g}$, microgram per gram; mg/kg, milligram per kilogram; PCB, polychlorinated biphenyl; EPT, Ephemeroptera, Plecoptera, and Trichoptera; HBI, Hilsenhoff Biotic Index; $\mu \mathrm{g} / \mathrm{L}$, microgram per liter; --, no data; RL, concentrations were below reporting level; *, fewer than 50 individual fish were collected, so the Wisconsin warmwater Index of Biotic Integrity should not be used (Lyons, 1992)]

\begin{tabular}{|c|c|c|c|c|c|c|}
\hline Phase I & Phase II & \multicolumn{4}{|c|}{ Phase I pesticides in tissues } & \multirow{2}{*}{$\begin{array}{l}\text { Phase II pesticides } \\
\text { detected in tissues }\end{array}$} \\
\hline Subwatersheds & $\begin{array}{c}\text { Site } \\
\text { abbreviation }\end{array}$ & $\begin{array}{c}\text { Total number } \\
\text { of results }\end{array}$ & $\begin{array}{l}\text { Number } \\
\text { of results } \\
\text { below RL }\end{array}$ & $\begin{array}{c}\text { Number } \\
\text { of results at } \\
\text { or above RL }\end{array}$ & $\begin{array}{c}\text { Percent } \\
\text { of results at } \\
\text { or above } R L\end{array}$ & \\
\hline \multicolumn{7}{|l|}{ Fox River Watershed } \\
\hline Muskego Lake & $\mathrm{JCM}$ & -- & -- & -- & -- & -- \\
\hline \multicolumn{7}{|c|}{ Kinnickinnic River Watershed } \\
\hline Kinnickinnic River & KRM & 111 & 111 & 0 & 0 & -- \\
\hline \multicolumn{7}{|c|}{ Menomonee River Watershed } \\
\hline Honey Creek & $\mathrm{HCW}$ & 8 & 8 & 0 & 0 & -- \\
\hline Little Menomonee River & LMM & 7 & 7 & 0 & 0 & -- \\
\hline Lower Menomonee River & MRW & 32 & 32 & 0 & 0 & p-p'-DDE and p-p'-DDD \\
\hline Upper Menomonee River & MRMF & -- & -- & -- & -- & -- \\
\hline Underwood Creek & UCW & -- & -- & -- & -- & -- \\
\hline Willow Creek & WCG & -- & -- & -- & -- & -- \\
\hline \multicolumn{7}{|l|}{ Milwaukee River Watershed } \\
\hline Lincoln Creek & LCM & 63 & 63 & 0 & 0 & -- \\
\hline \multirow[t]{3}{*}{ Lower Milwaukee River ${ }^{1}$} & $\mathrm{MRC}^{1}$ & 296 & 292 & 4 & 1 & -- \\
\hline & $\mathrm{MRM}^{1}$ & & & & & p-p'-DDE \\
\hline & $\mathrm{MRJ}^{1}$ & & & & & -- \\
\hline \multicolumn{7}{|l|}{ Oak Creek Watershed } \\
\hline Lower Oak Creek & OCSM & 28 & 28 & 0 & 0 & -- \\
\hline \multicolumn{7}{|l|}{ Root River Watershed } \\
\hline Middle Root River & RRF & 6 & 6 & 0 & 0 & no pesticides detected \\
\hline Upper Root River & RRG & -- & -- & -- & -- & -- \\
\hline
\end{tabular}

${ }^{1}$ Three of the Phase II sites sampled were in the Lower Milwaukee River Subwatershed. Comparisons could be drawn individually between each site and the Phase I subwatershed; however, for the discussion in the text, these three sites were not considered adequately representative of that subwatershed due to their location and the size and complexity of the subwatershed. Comparisons of these sites to the subwatershed were omitted when discussing overall trends between Phase I and Phase II data in the text; however, contamination of this subwatershed with synthetic organic contaminants (especially PCBs) was well documented and was discussed in general terms using the data from the Milwaukee River at Milwaukee site.

${ }^{2}$ Values given as median concentrations.

${ }^{3}$ Phase I concentrations were originally published in micrograms per gram, which is equivalent to milligrams per kilogram.

${ }^{4}$ Values given as total number of fish species.

${ }^{5}$ Phase I values given as median IBI scores for 1990-2002. Phase II IBI scores were determined from a single community survey.

${ }^{6}$ Phase I values given as median percentages of EPT taxa. Phase II percentages of EPT taxa were determined from a single community survey.

${ }^{7}$ Phase I values given as median HBI values. Phase II HBI-10 values were determined from a single community survey. 


\begin{tabular}{|c|c|c|c|c|c|c|c|c|}
\hline \multirow[b]{3}{*}{$\begin{array}{l}\text { Total number } \\
\text { of results }\end{array}$} & \multirow{2}{*}{\multicolumn{3}{|c|}{ Phase I PCBs in tissues }} & \multirow{3}{*}{$\begin{array}{c}\text { Phase II } \\
\text { PCB detected } \\
\text { in tissues }\end{array}$} & \multicolumn{4}{|c|}{ Fish species abundance } \\
\hline & & & & & \multicolumn{3}{|c|}{ Phase I ${ }^{4}$} & \multirow{2}{*}{$\begin{array}{c}\text { Phase II }{ }^{4} \\
2004\end{array}$} \\
\hline & $\begin{array}{c}\text { Number of } \\
\text { results } \\
\text { below RL }\end{array}$ & $\begin{array}{c}\text { Number of } \\
\text { results at or } \\
\text { above RL }\end{array}$ & $\begin{array}{c}\text { Percent of } \\
\text { results at } \\
\text { or above RL }\end{array}$ & & 1970-1979 & 1980-1989 & $1990-2002$ & \\
\hline-- & -- & -- & -- & -- & 37 & -- & -- & 15 \\
\hline 1 & 1 & 0 & 0 & -- & 12 & 6 & 13 & 1 \\
\hline-- & -- & -- & -- & -- & 5 & 14 & 13 & 6 \\
\hline 7 & 7 & 0 & 0 & -- & 8 & 12 & -- & 5 \\
\hline 5 & 5 & 0 & 0 & Aroclor 1260 & 13 & 18 & 26 & 3 \\
\hline 2 & 2 & 0 & 0 & -- & 19 & 26 & -- & 13 \\
\hline -- & -- & -- & -- & -- & 4 & 12 & 11 & 8 \\
\hline-- & -- & -- & -- & -- & 12 & 12 & -- & 6 \\
\hline 4 & 0 & 4 & 100 & -- & 13 & 23 & 8 & 8 \\
\hline \multirow[t]{3}{*}{15} & 1 & 14 & 93 & -- & 40 & 49 & 54 & 22 \\
\hline & & & & $\begin{array}{c}\text { Aroclor 1248/ } \\
1254 / 1260\end{array}$ & & & & 18 \\
\hline & & & & -- & & & & -- \\
\hline 1 & 1 & 0 & 0 & -- & 7 & 9 & 10 & 7 \\
\hline 1 & 1 & 0 & 0 & no PCBs detected & 24 & 13 & 5 & 12 \\
\hline-- & -- & -- & -- & -- & 6 & -- & -- & 9 \\
\hline
\end{tabular}


Appendix 5. Comparison of median constituent concentrations and detections between Phase I and Phase II of the MMSD Corridor Study-Continued.

[mg/L, milligram per liter; mg/m³, milligram per cubic meter; CFU/100ml, colony-forming unit per 100 milliliters; $\mu \mathrm{g} / \mathrm{g}$, microgram per gram; mg/kg, milligram per kilogram; PCB, polychlorinated biphenyl; EPT, Ephemeroptera, Plecoptera, and Trichoptera; HBI, Hilsenhoff Biotic Index; $\mu \mathrm{g} / \mathrm{L}$, microgram per liter; --, no data; RL, concentrations were below reporting level; *, fewer than 50 individual fish were collected, so the Wisconsin warmwater Index of Biotic Integrity should not be used (Lyons, 1992)]

\begin{tabular}{|c|c|c|c|c|c|c|c|}
\hline \multirow{2}{*}{$\begin{array}{c}\text { Phase I } \\
\text { Subwatersheds }\end{array}$} & \multirow{2}{*}{$\begin{array}{c}\text { Phase II } \\
\text { Site } \\
\text { abbreviation }\end{array}$} & \multicolumn{2}{|c|}{$\begin{array}{l}\text { Fish Index of } \\
\text { Biotic Integrity }\end{array}$} & \multicolumn{2}{|c|}{$\begin{array}{c}\text { Macroinvertebrate EPT } \\
\text { (percent of EPT taxa) }\end{array}$} & \multicolumn{2}{|c|}{$\begin{array}{c}\text { Macroinvertebrate } \\
\text { HBI }\end{array}$} \\
\hline & & Phase $\mathbf{I}^{5}$ & Phase $\|^{5}$ & Phase ${ }^{6}$ & Phase II $^{6}$ & $\begin{array}{c}\text { Phase } \mathrm{I}^{7} \\
\text { (HBI score) }\end{array}$ & $\begin{array}{c}\text { Phase II } \\
\text { (HBI-10 } \\
\text { score) }\end{array}$ \\
\hline \multicolumn{8}{|l|}{ Fox River Watershed } \\
\hline Muskego Lake & $\mathrm{JCM}$ & -- & 22 & 26 & 29 & 5.8 & 5.58 \\
\hline \multicolumn{8}{|c|}{ Kinnickinnic River Watershed } \\
\hline Kinnickinnic River & KRM & 20 & $*$ & 0 & 7 & 6.11 & 6.52 \\
\hline \multicolumn{8}{|l|}{ Menomonee River Watershed } \\
\hline Honey Creek & $\mathrm{HCW}$ & 20 & 7 & 17 & 17 & 6.15 & 5.28 \\
\hline Little Menomonee River & LMM & -- & $*$ & 0 & 23 & 8 & 5.33 \\
\hline Lower Menomonee River & MRW & 15 & 12 & 8 & 31 & 6.21 & 5.86 \\
\hline Upper Menomonee River & MRMF & -- & 30 & 28 & 44 & 5.68 & 5.56 \\
\hline Underwood Creek & UCW & 15 & 10 & 2 & 18 & 6.1 & 5.96 \\
\hline Willow Creek & WCG & -- & 25 & 12 & 17 & 4.87 & 5.45 \\
\hline \multicolumn{8}{|l|}{ Milwaukee River Watershed } \\
\hline Lincoln Creek & LCM & 10 & $*$ & 0 & 18 & 6.2 & 6.3 \\
\hline \multirow[t]{3}{*}{ Lower Milwaukee River ${ }^{1}$} & $\mathrm{MRC}^{1}$ & 62 & 70 & 19 & 51 & 5.72 & 5.01 \\
\hline & $\mathrm{MRM}^{1}$ & & 60 & & 39 & & 5.2 \\
\hline & $\mathrm{MRJ}^{1}$ & & -- & & -- & & -- \\
\hline \multicolumn{8}{|l|}{ Oak Creek Watershed } \\
\hline Lower Oak Creek & OCSM & 17 & 10 & 24 & 22 & 6.64 & 5.55 \\
\hline \multicolumn{8}{|l|}{ Root River Watershed } \\
\hline Middle Root River & RRF & -- & 14 & 50 & 28 & 6.29 & 5.92 \\
\hline Upper Root River & RRG & -- & 12 & 3 & 18 & 7.13 & 6.15 \\
\hline
\end{tabular}

${ }^{1}$ Three of the Phase II sites sampled were in the Lower Milwaukee River Subwatershed. Comparisons could be drawn individually between each site and the Phase I subwatershed; however, for the discussion in the text, these three sites were not considered adequately representative of that subwatershed due to their location and the size and complexity of the subwatershed. Comparisons of these sites to the subwatershed were omitted when discussing overall trends between Phase I and Phase II data in the text; however, contamination of this subwatershed with synthetic organic contaminants (especially PCBs) was well documented and was discussed in general terms using the data from the Milwaukee River at Milwaukee site.

${ }^{2}$ Values given as median concentrations.

${ }^{3}$ Phase I concentrations were originally published in micrograms per gram, which is equivalent to milligrams per kilogram.

${ }^{4}$ Values given as total number of fish species.

${ }^{5}$ Phase I values given as median IBI scores for 1990-2002. Phase II IBI scores were determined from a single community survey.

${ }^{6}$ Phase I values given as median percentages of EPT taxa. Phase II percentages of EPT taxa were determined from a single community survey.

${ }^{7}$ Phase I values given as median HBI values. Phase II HBI-10 values were determined from a single community survey. 
Appendix 6. Hydrologic conditions during Phase II of the Milwaukee Metropolitan Sewerage District (MMSD) Corridor Study.

Appendix 6A. Water-discharge hydrographs for water years 2004-2005 at the 12 Phase II stream sites with gages in the Milwaukee Metropolitan Sewerage District (MMSD) planning area. Period of record annual mean does not include data from the 2004 and 2005 water years.
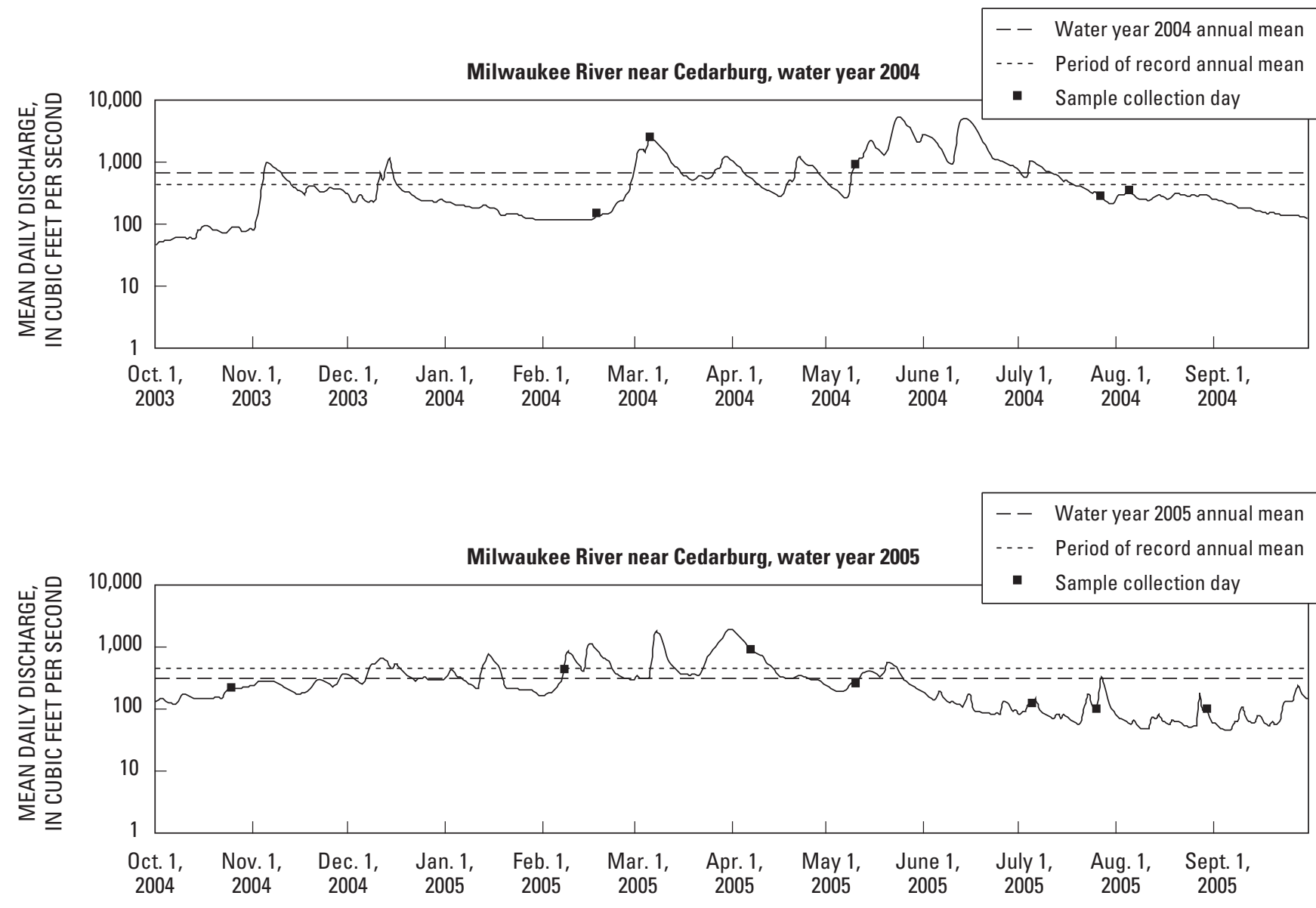

Figure 6-1. Milwaukee River near Cedarburg. 
Appendix 6A. Water-discharge hydrographs for water years 2004-2005 at the 12 Phase II stream sites with gages in the Milwaukee Metropolitan Sewerage District (MMSD) planning area_Continued.
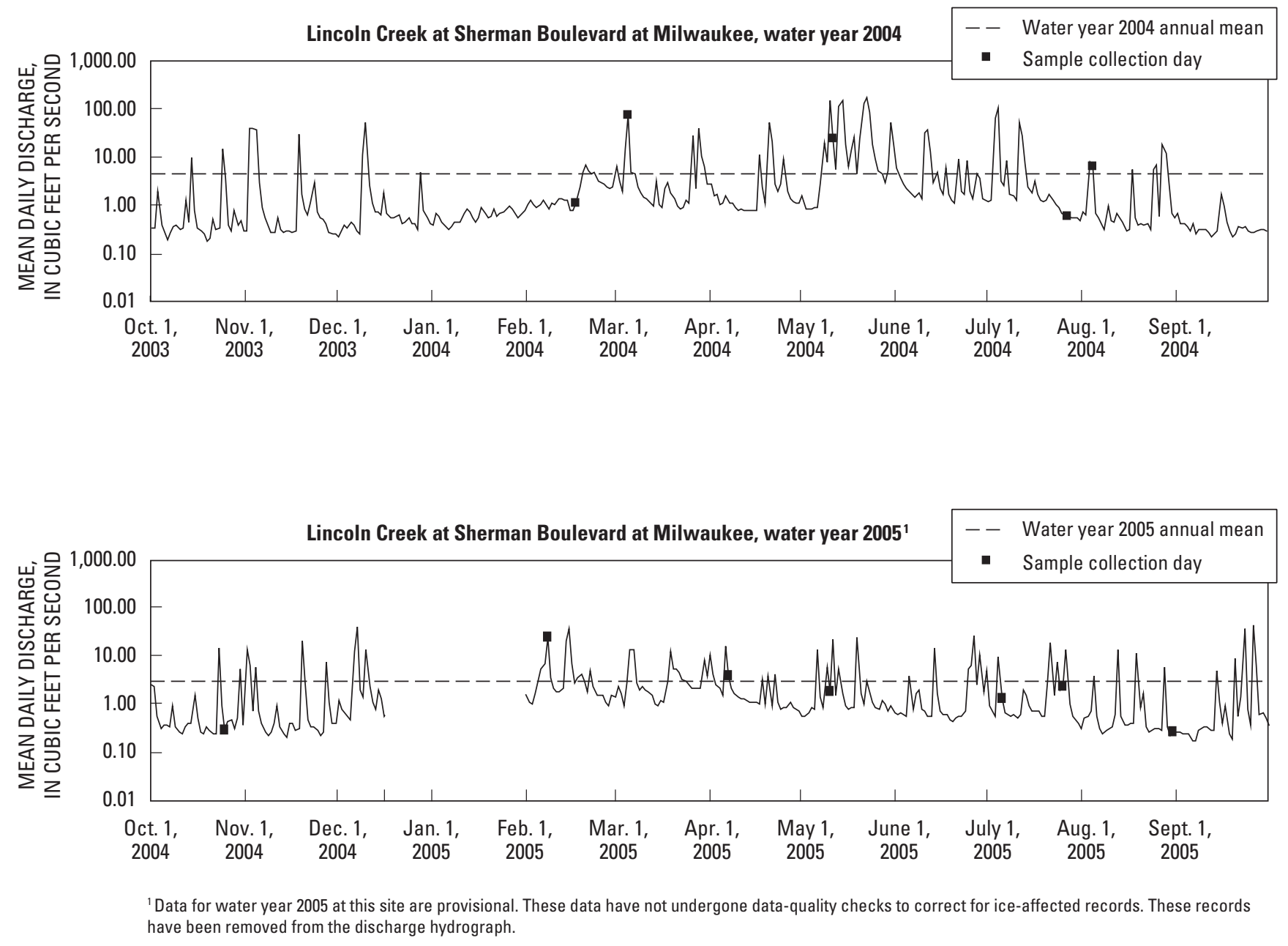

Figure 6-2. Lincoln Creek at 47th Street at Milwaukee. A period of record annual mean is not provided for this site because it has less than 20 years of hydrologic data. 
Appendix 6A. Water-discharge hydrographs for water years 2004-2005 at the 12 Phase II stream sites with gages in the Milwaukee Metropolitan Sewerage District (MMSD) planning area-Continued. Period of record annual mean does not include data from the 2004 and 2005 water years.
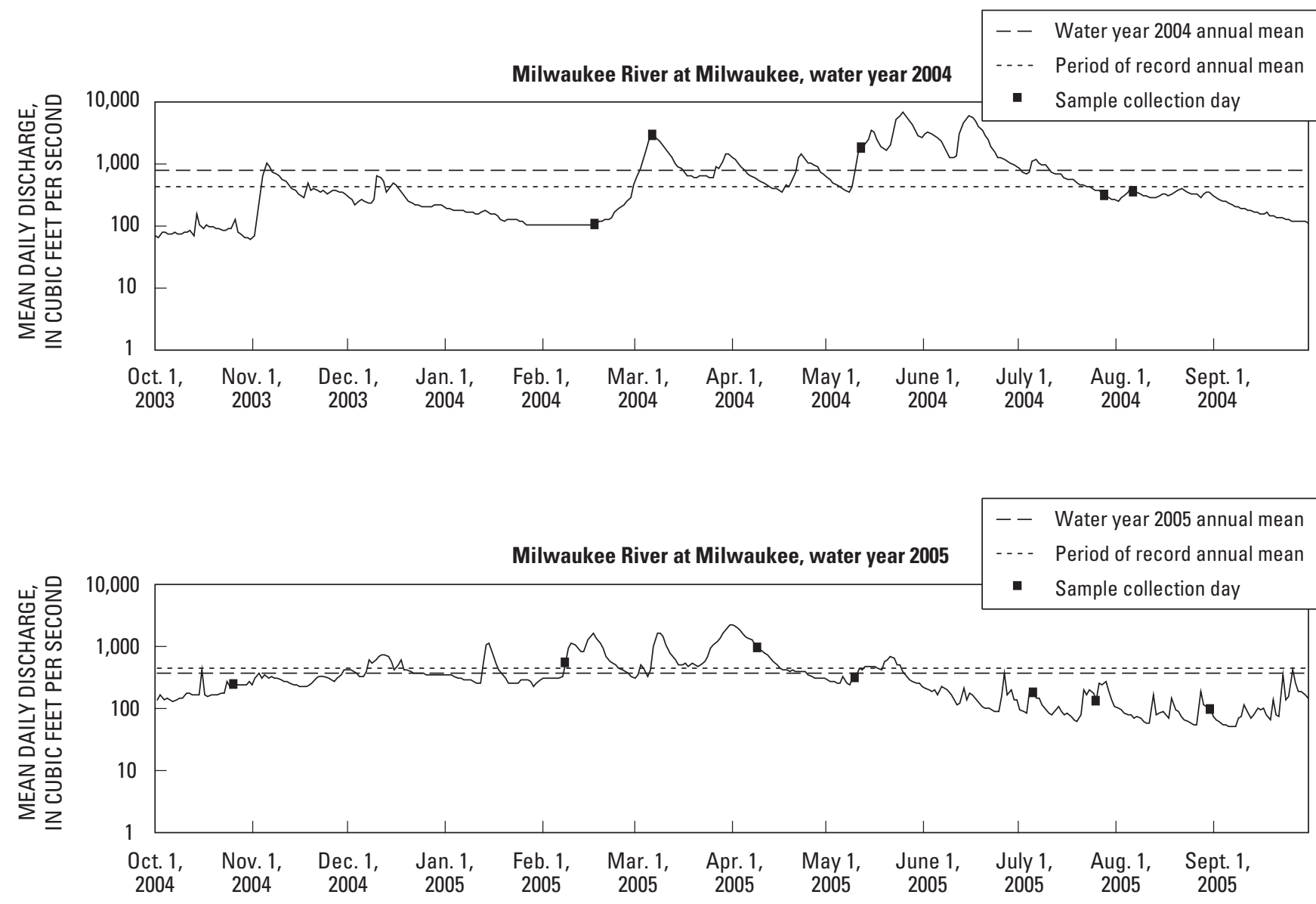

Figure 6-3. Milwaukee River at Milwaukee. 
Appendix 6A. Water-discharge hydrographs for water years 2004-2005 at the 12 Phase II stream sites with gages in the Milwaukee Metropolitan Sewerage District (MMSD) planning area-Continued. Period of record annual mean does not include data from the 2004 and 2005 water years.
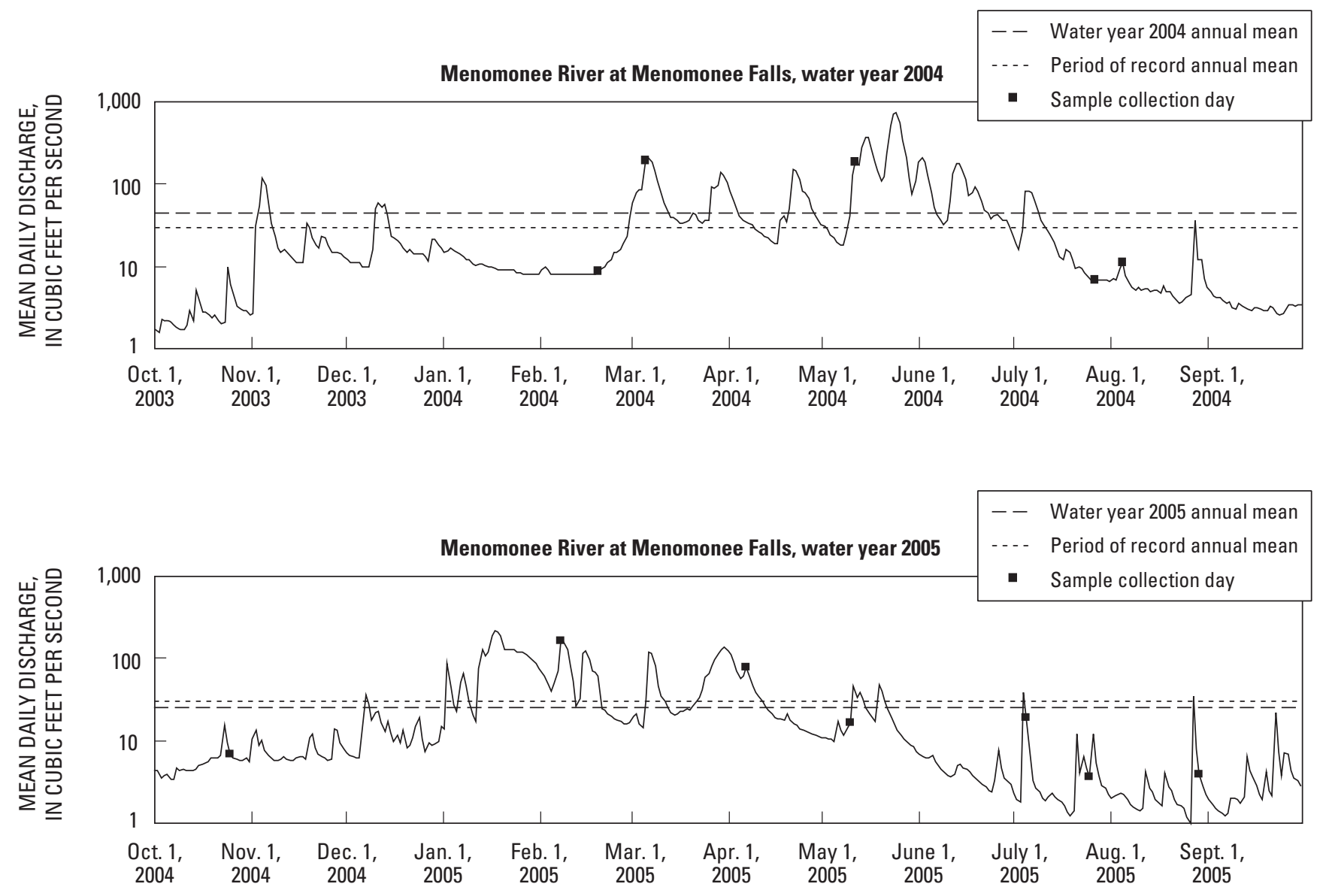

Figure 6-4. Menomonee River at Menomonee Falls. 
Appendix 6A. Water-discharge hydrographs for water years 2004-2005 at the 12 Phase II stream sites with gages in the Milwaukee Metropolitan Sewerage District (MMSD) planning area—Continued.
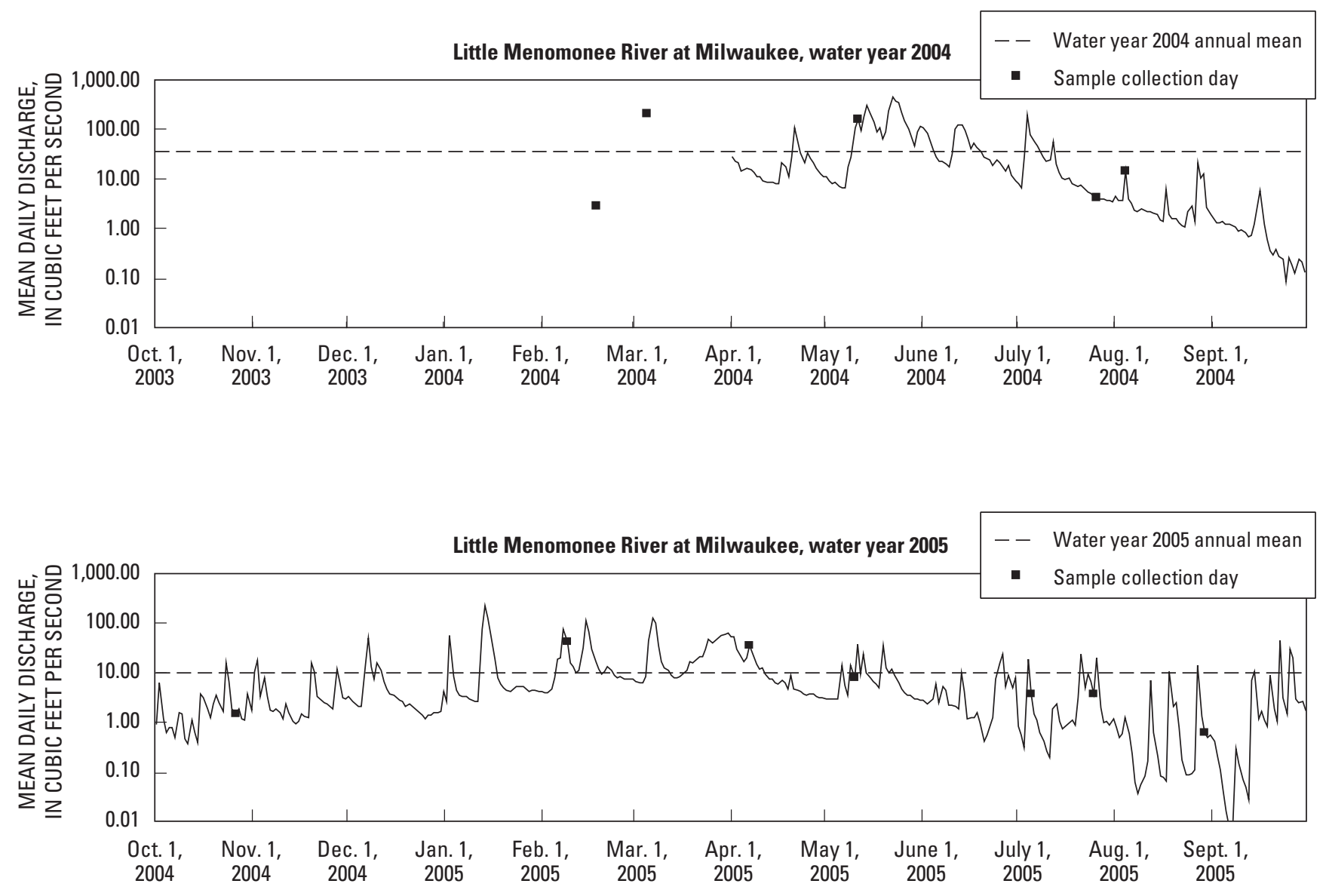

Figure 6-5. Little Menomonee River at Milwaukee. Prior to the addition of a gage at this site in April of 2004, current-meter discharge measurements were made during water-quality sampling. A period of record annual mean is not provided for this site because it has less than 20 years of hydrologic data. 
Appendix 6A. Water-discharge hydrographs for water years 2004-2005 at the 12 Phase II stream sites with gages in the Milwaukee Metropolitan Sewerage District (MMSD) planning area-Continued. Period of record annual mean does not include data from the 2004 and 2005 water years.
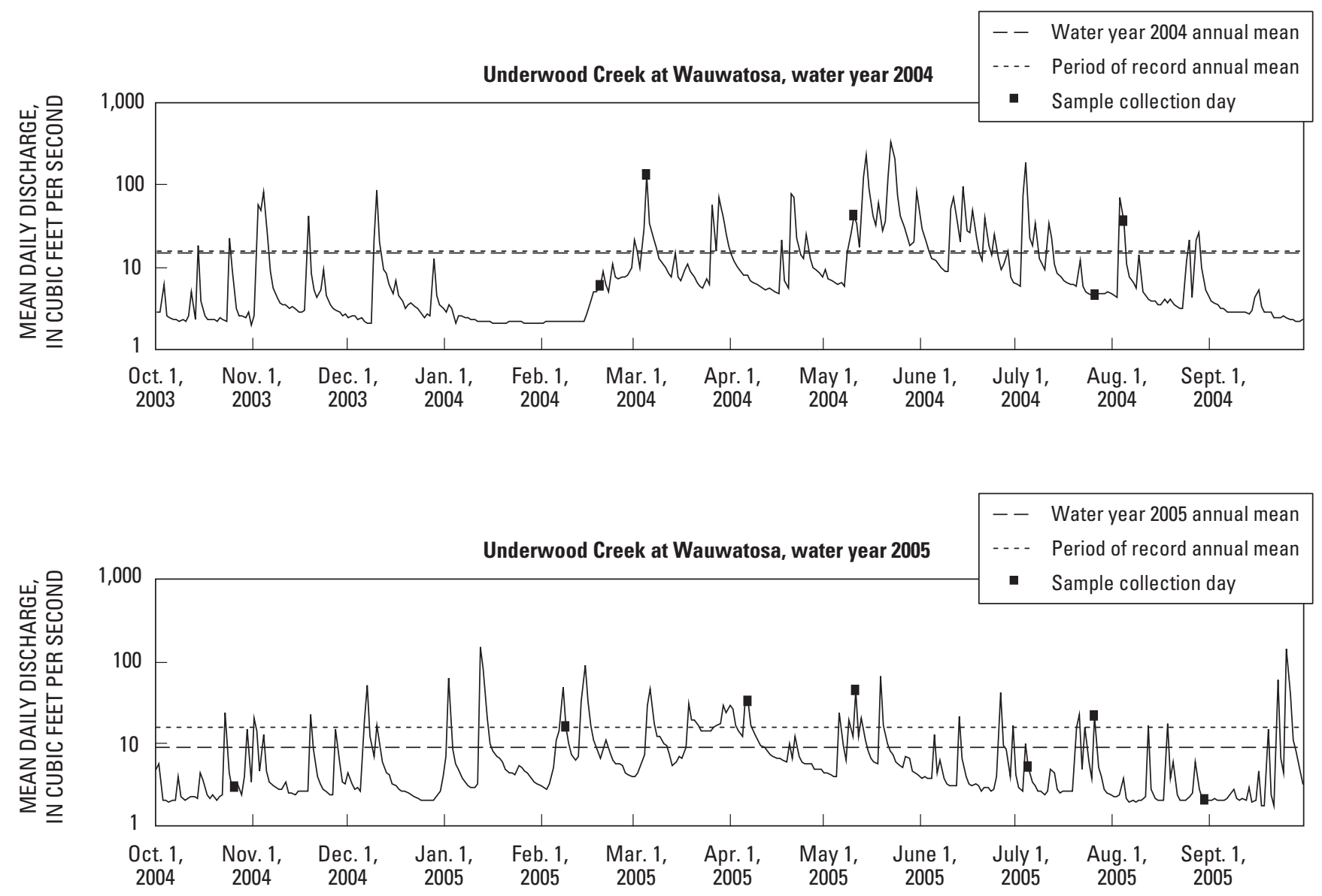

Figure 6-6. Underwood Creek at Wauwatosa. 
Appendix 6A. Water-discharge hydrographs for water years 2004-2005 at the 12 Phase II stream sites with gages in the Milwaukee Metropolitan Sewerage District (MMSD) planning area—Continued.
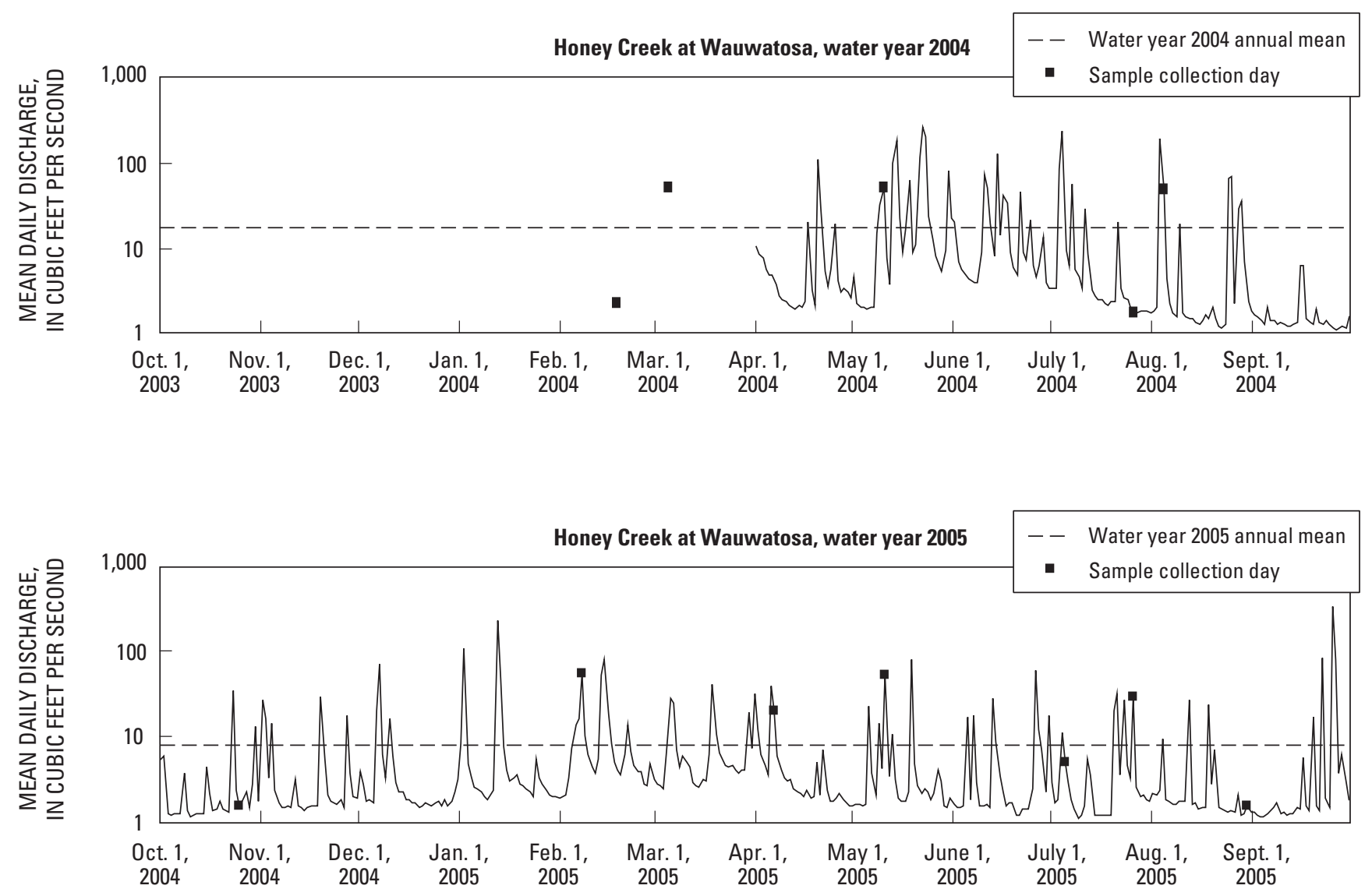

Figure 6-7. Honey Creek at Wauwatosa. Prior to the addition of a gage at this site in April of 2004, current-meter discharge measurements were made during water-quality sampling. A period of record annual mean is not provided for this site because it has less than 20 years of hydrologic data. 
Appendix 6A. Water-discharge hydrographs for water years 2004-2005 at the 12 Phase II stream sites with gages in the Milwaukee Metropolitan Sewerage District (MMSD) planning area-Continued. Period of record annual mean does not include data from the 2004 and 2005 water years.
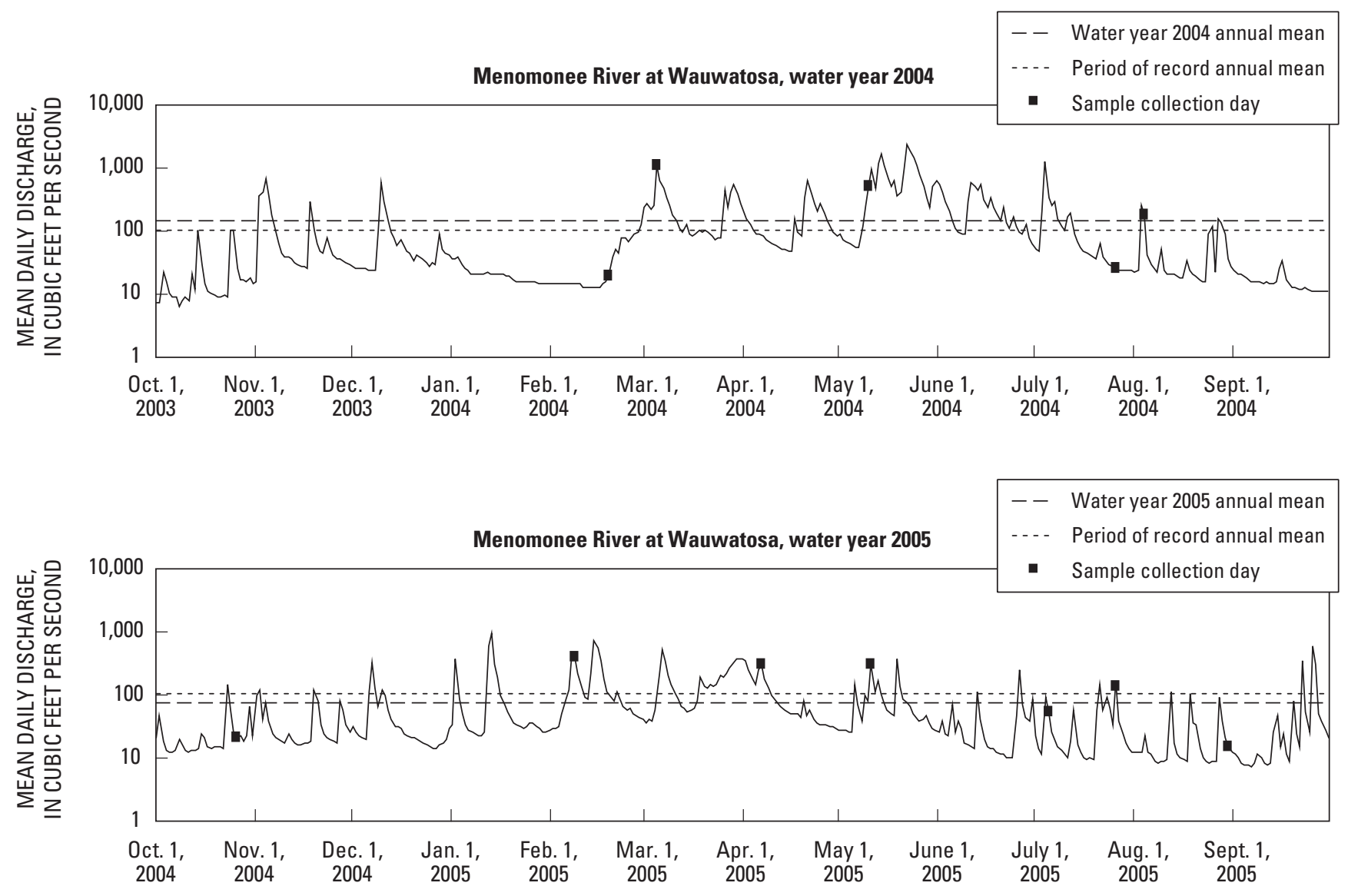

Figure 6-8. Menomonee River at Wauwatosa. 
Appendix 6A. Water-discharge hydrographs for water years 2004-2005 at the 12 Phase II stream sites with gages in the Milwaukee Metropolitan Sewerage District (MMSD) planning area-Continued. Period of record annual mean does not include data from the 2004 and 2005 water years.
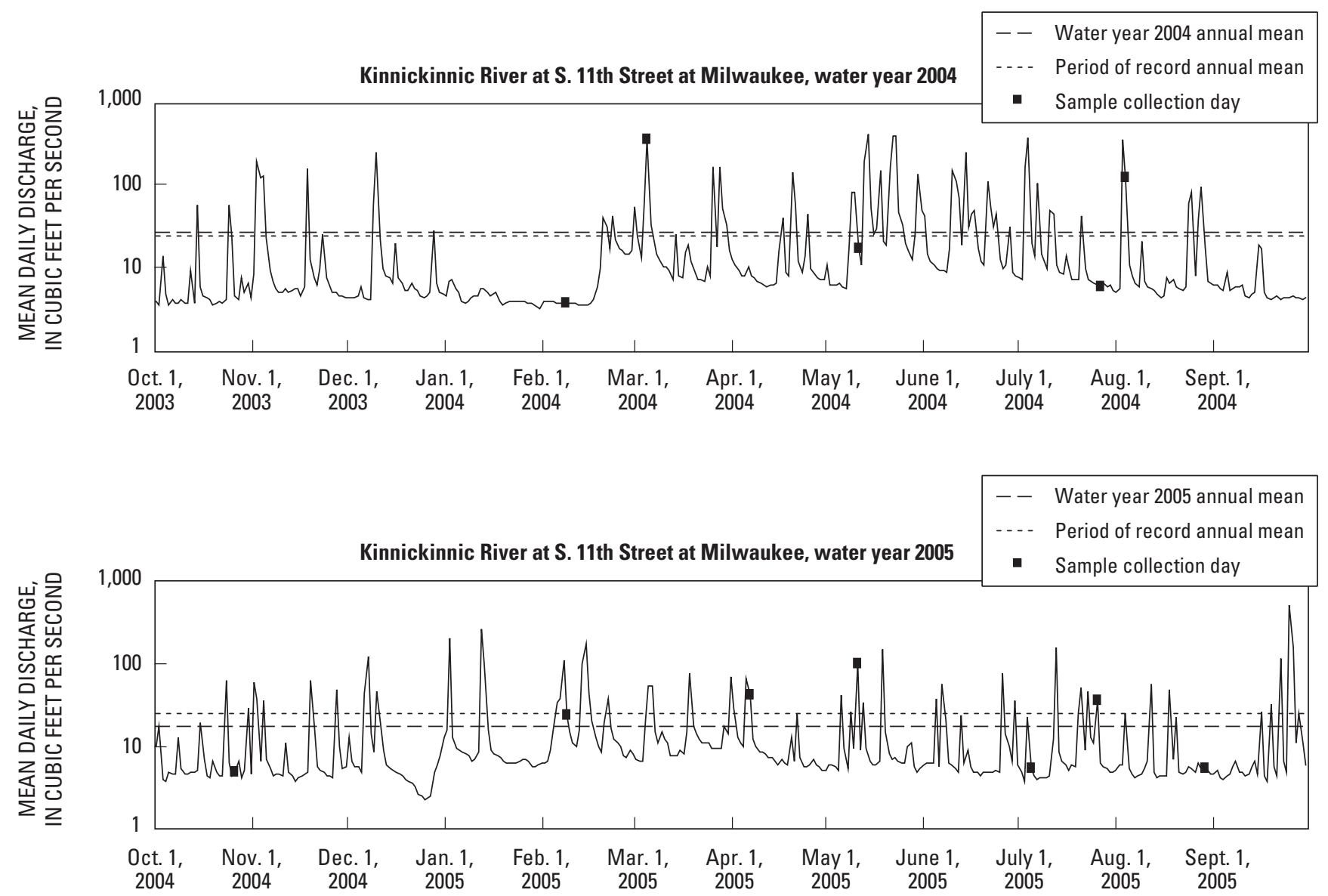

Figure 6-9. Kinnickinnic River at S. 11th Street at Milwaukee. 
Appendix 6A. Water-discharge hydrographs for water years 2004-2005 at the 12 Phase II stream sites with gages in the Milwaukee Metropolitan Sewerage District (MMSD) planning area-Continued. Period of record annual mean does not include data from the 2004 and 2005 water years.
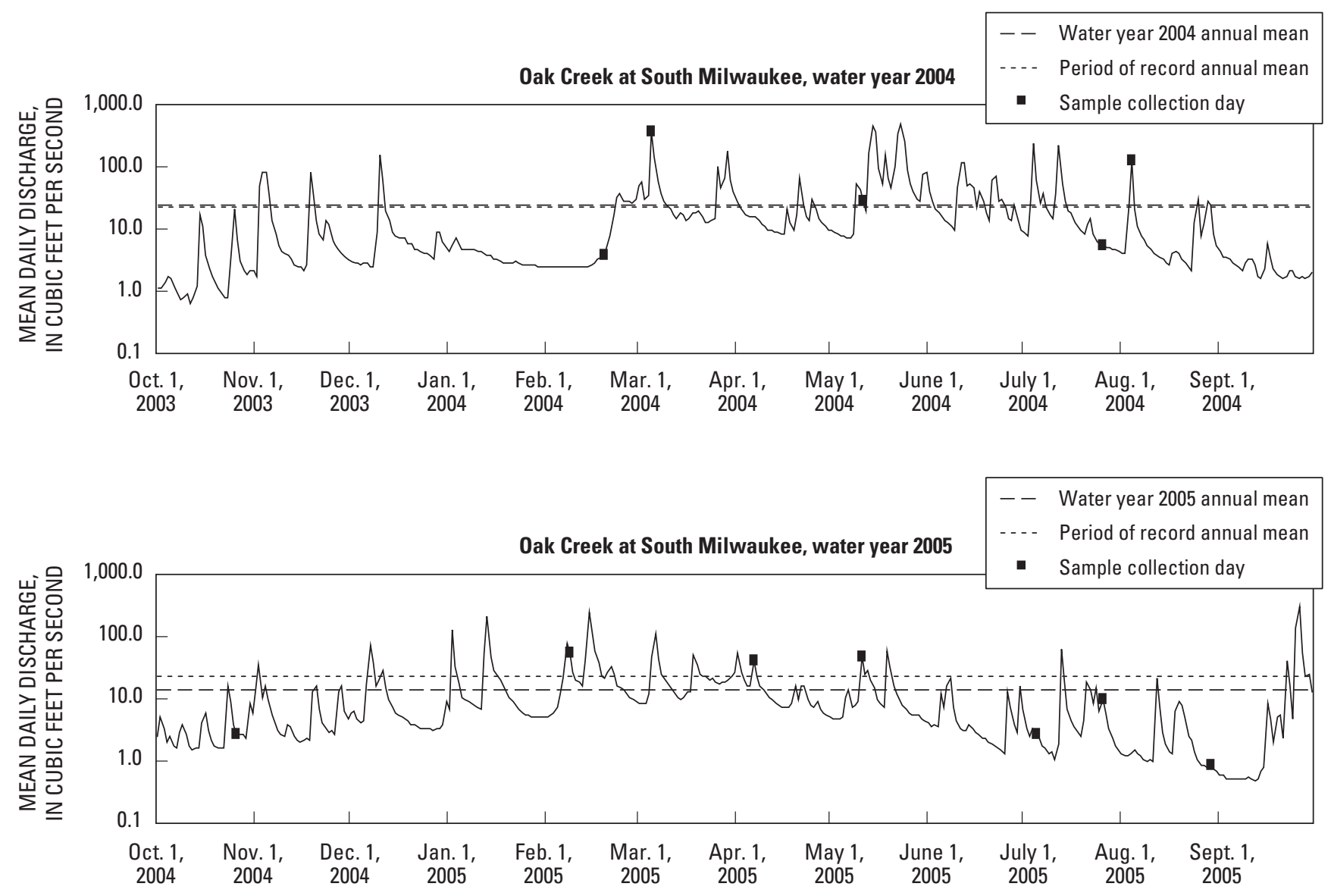

Figure 6-10. Oak Creek at South Milwaukee. 
Appendix 6A. Water-discharge hydrographs for water years 2004-2005 at the 12 Phase II stream sites with gages in the Milwaukee Metropolitan Sewerage District (MMSD) planning area—Continued.
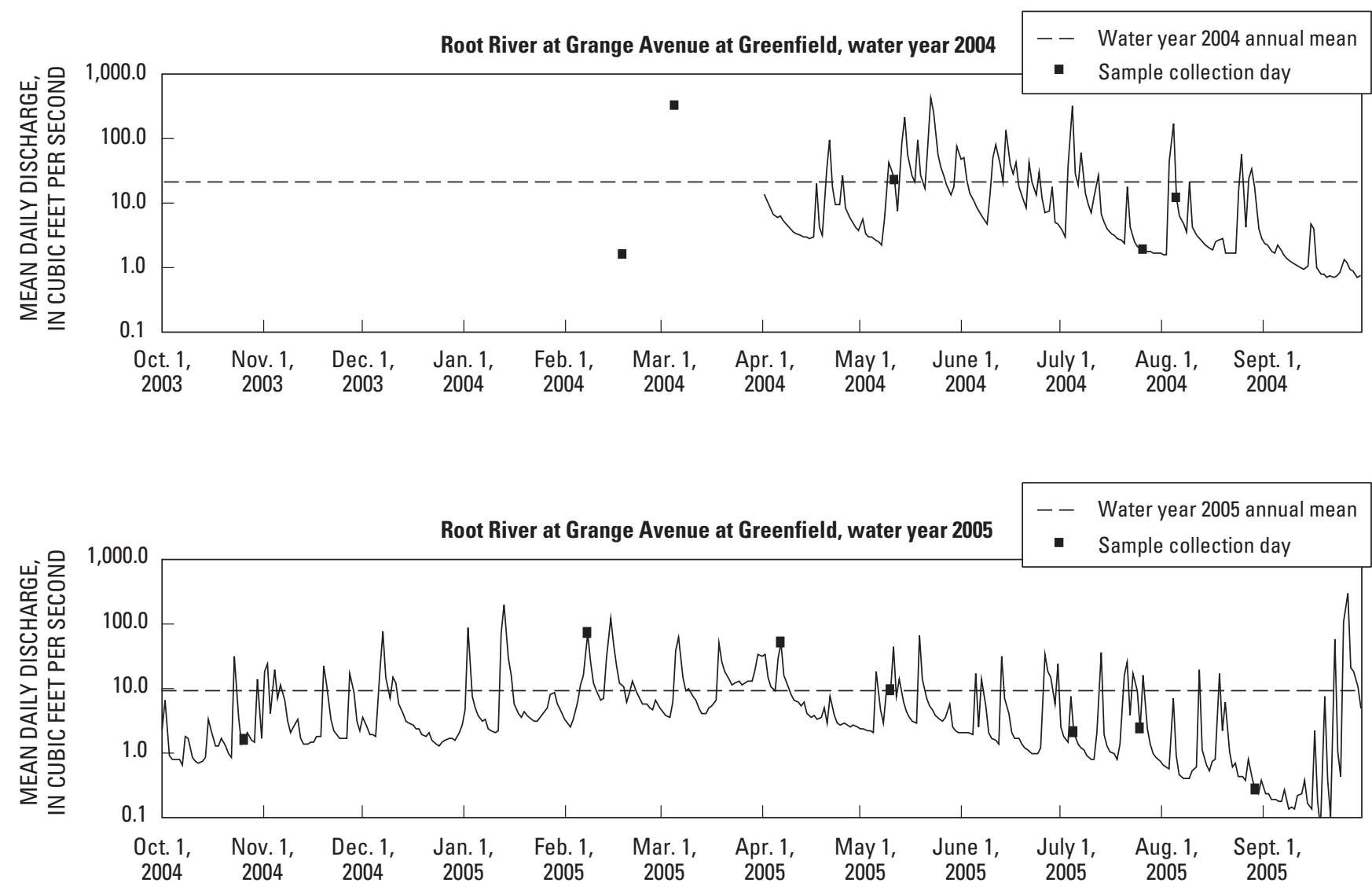

Figure 6-11. Root River at Grange Avenue at Greenfield. Prior to the addition of a gage at this site in April of 2004, current-meter discharge measurements were made during water-quality sampling. A period of record annual mean is not provided for this site because it has less than 20 years of hydrologic data. 
Appendix 6A. Water-discharge hydrographs for water years 2004-2005 at the 12 Phase II stream sites with gages in the Milwaukee Metropolitan Sewerage District (MMSD) planning area-Continued. Period of record annual mean does not include data from the 2004 and 2005 water years.
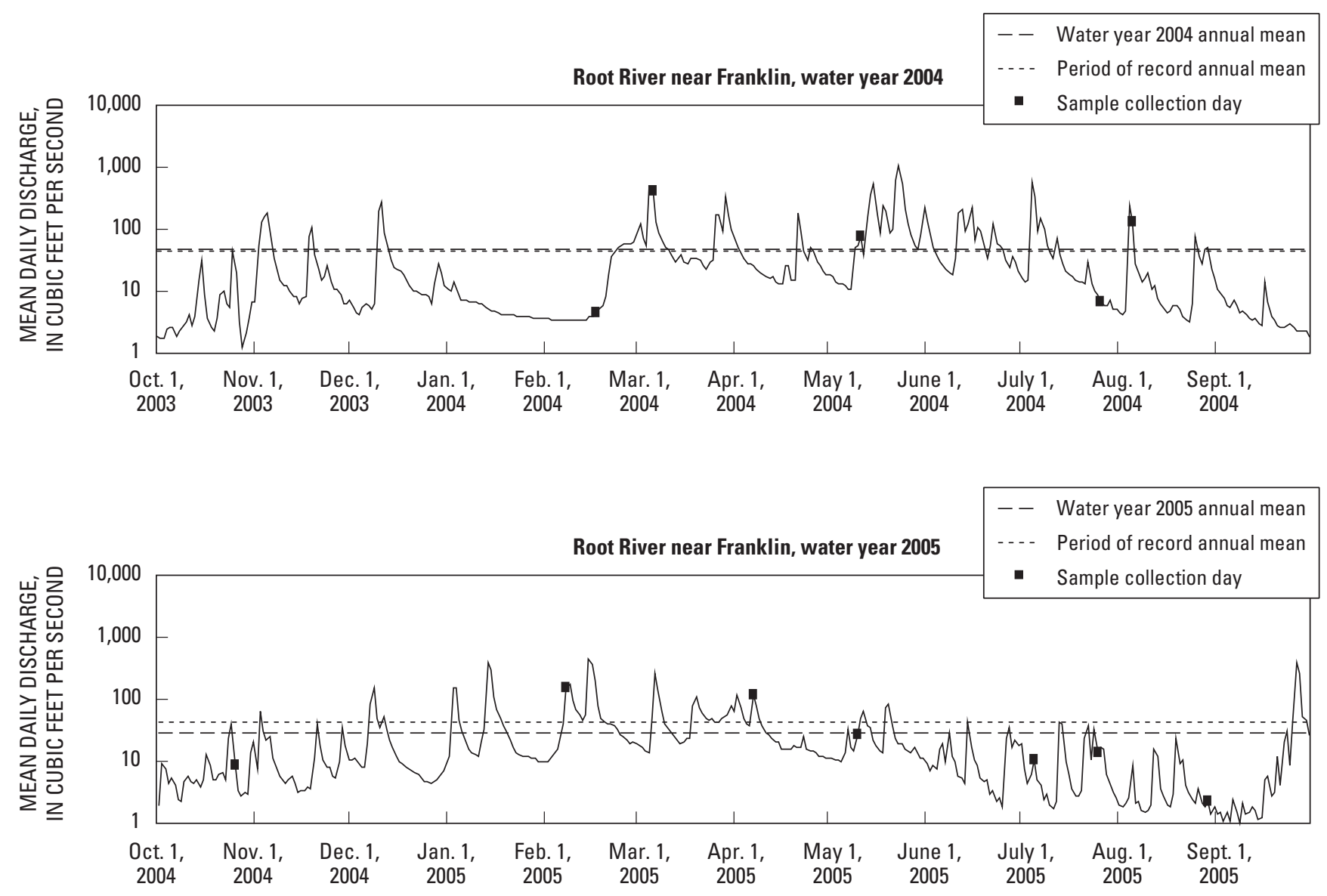

Figure 6-12. Root River near Franklin. 
Appendix 6B. Monthly runoff spanning more than 20 years for the eight Phase II stream sites with records in the Milwaukee Metropolitan Sewerage District (MMSD) planning area, Wis. Long-term means for runoff do not include data from the 2004 and 2005 water years.
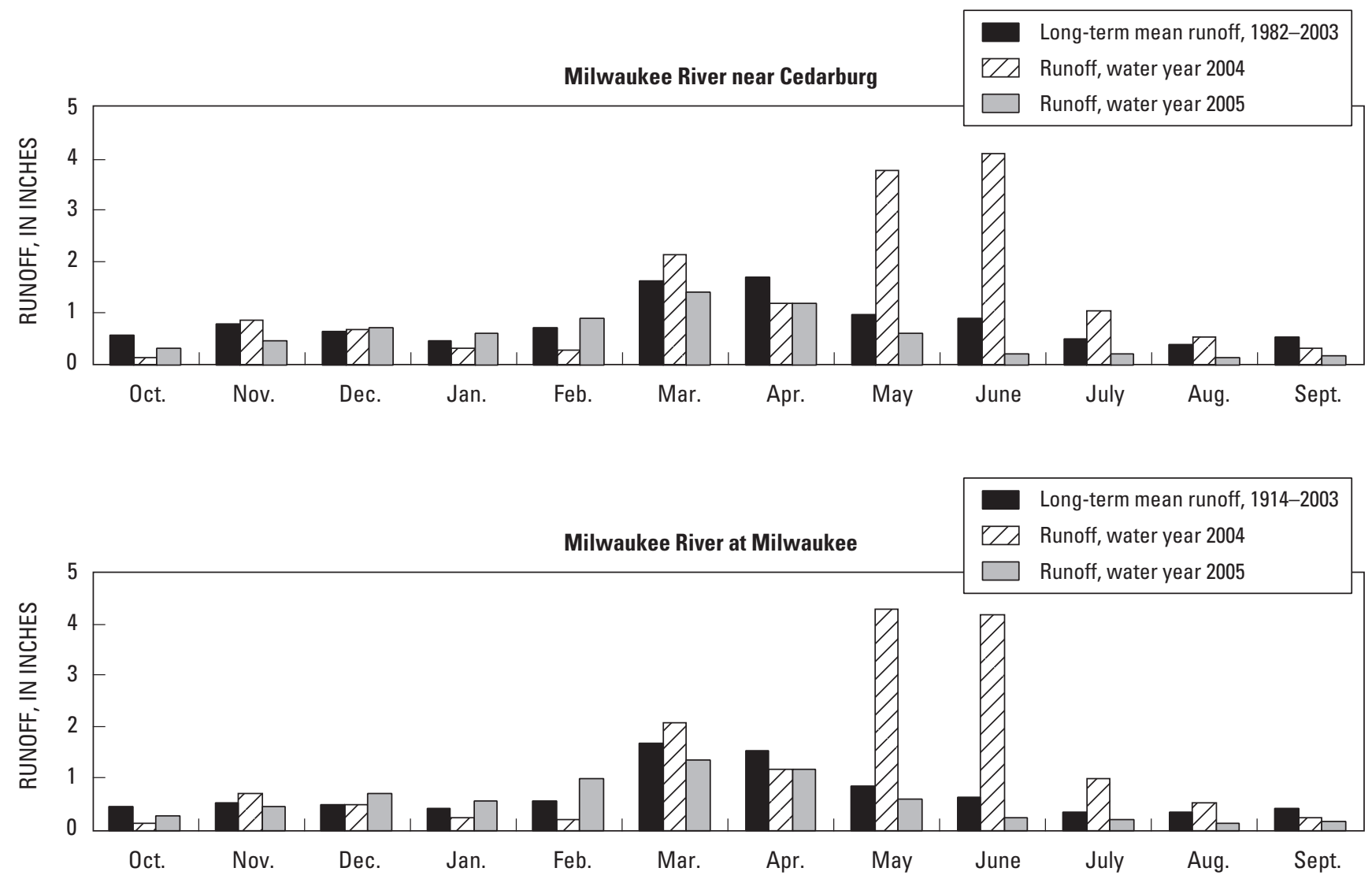

Figure 6-13. Monthly runoff, in inches, for water years 2004 and 2005 and for the period of record. 
Appendix 6B. Monthly runoff spanning more than 20 years for the eight Phase II stream sites with records in the Milwaukee Metropolitan Sewerage District (MMSD) planning area, Wis.-Continued. Long-term means for runoff do not include data from the 2004 and 2005 water years.
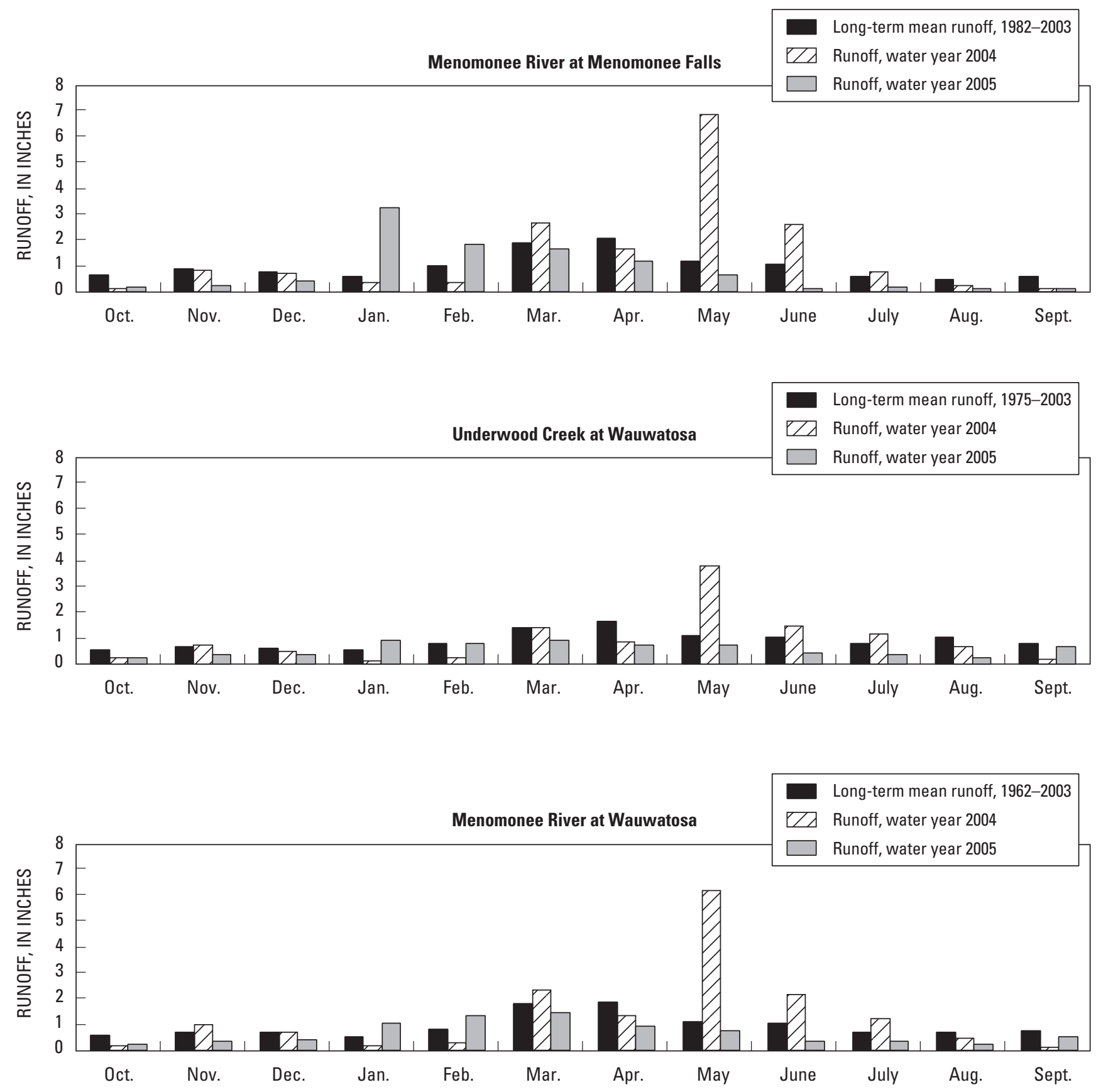

Figure 6-13. Monthly runoff, in inches, for water years 2004 and 2005 and for the period of record—Continued. 
Appendix 6B. Monthly runoff spanning more than 20 years for the eight Phase II stream sites with records in the Milwaukee Metropolitan Sewerage District (MMSD) planning area, Wis. - Continued. Long-term means for runoff do not include data from the 2004 and 2005 water years.
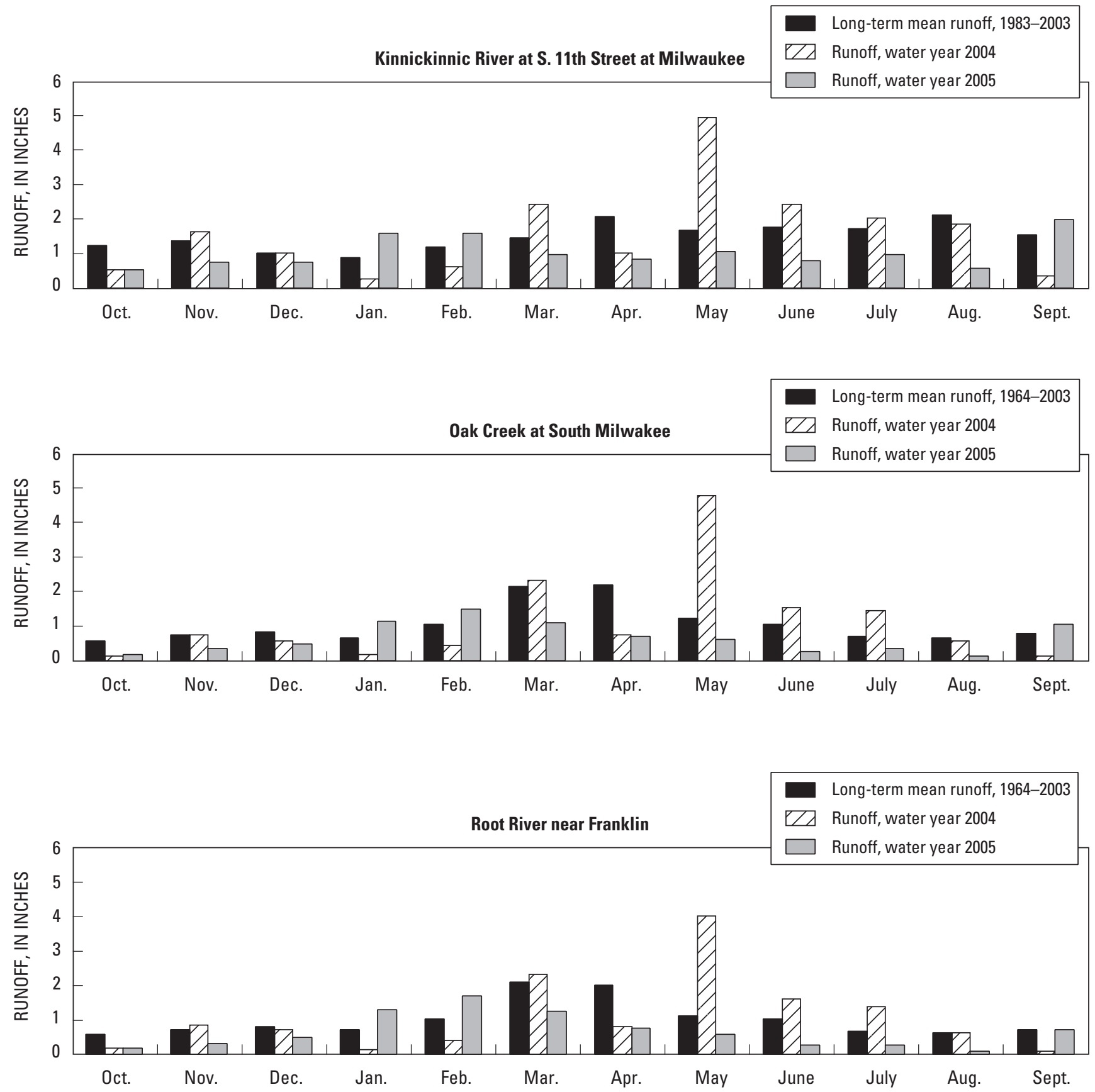

Figure 6-13. Monthly runoff, in inches, for water years 2004 and 2005 and for the period of record —Continued. 


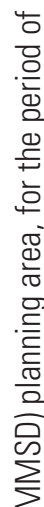

ț
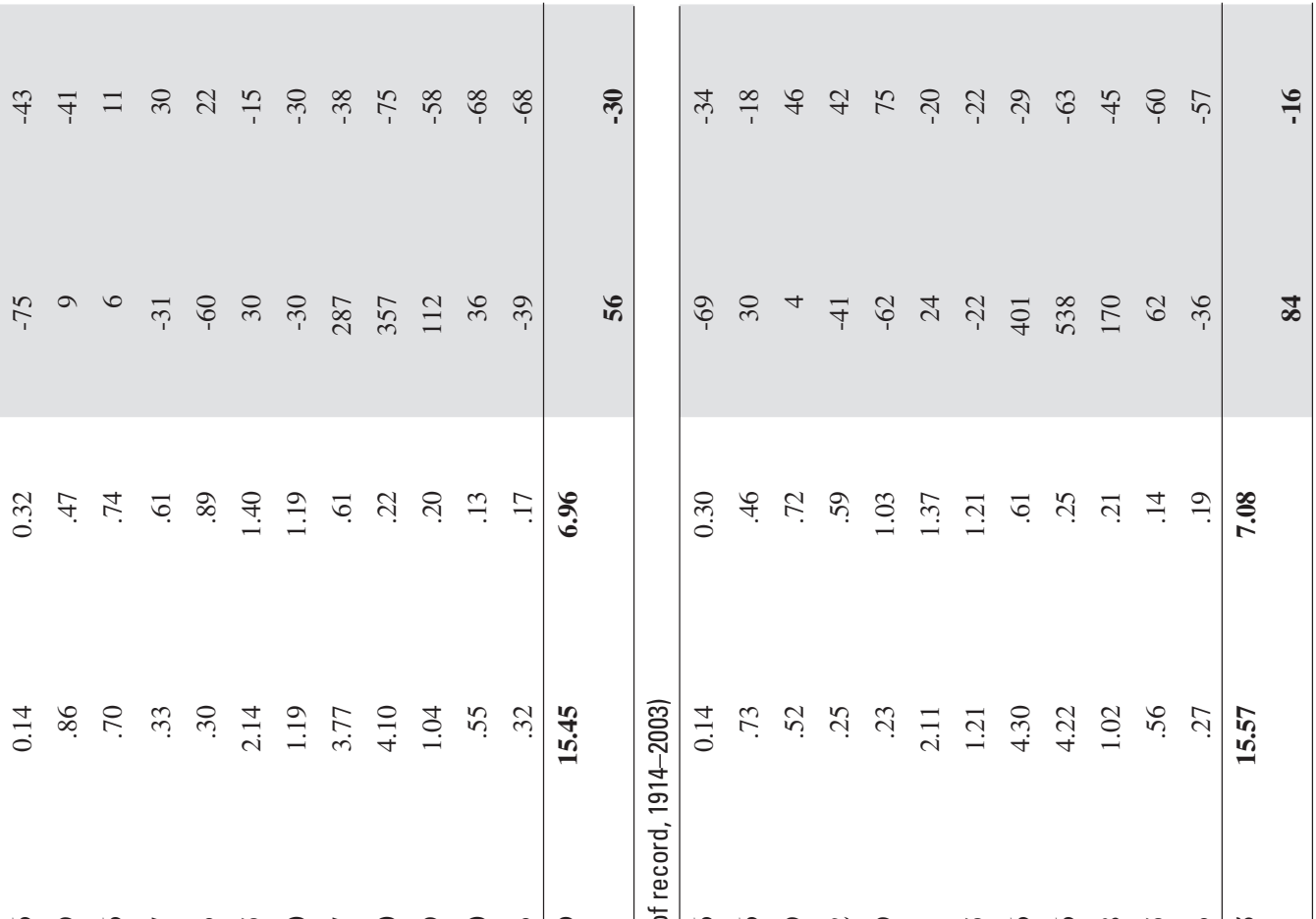

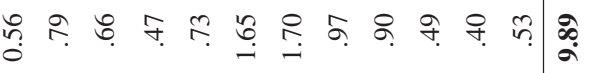

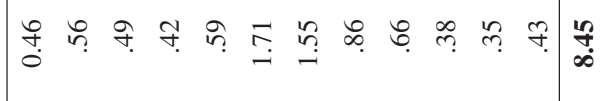

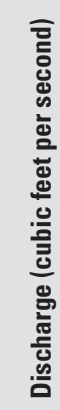

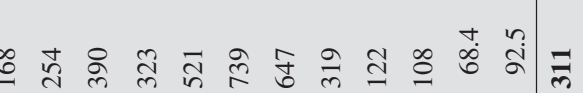
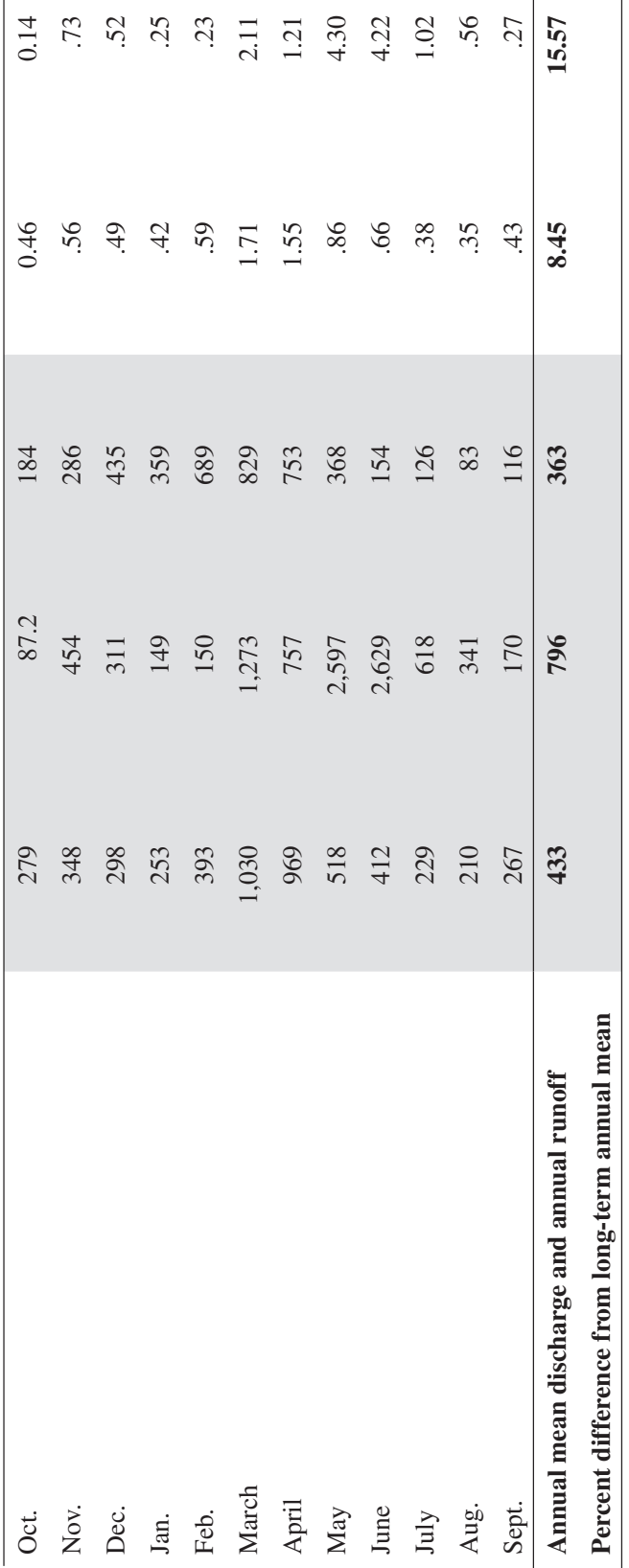


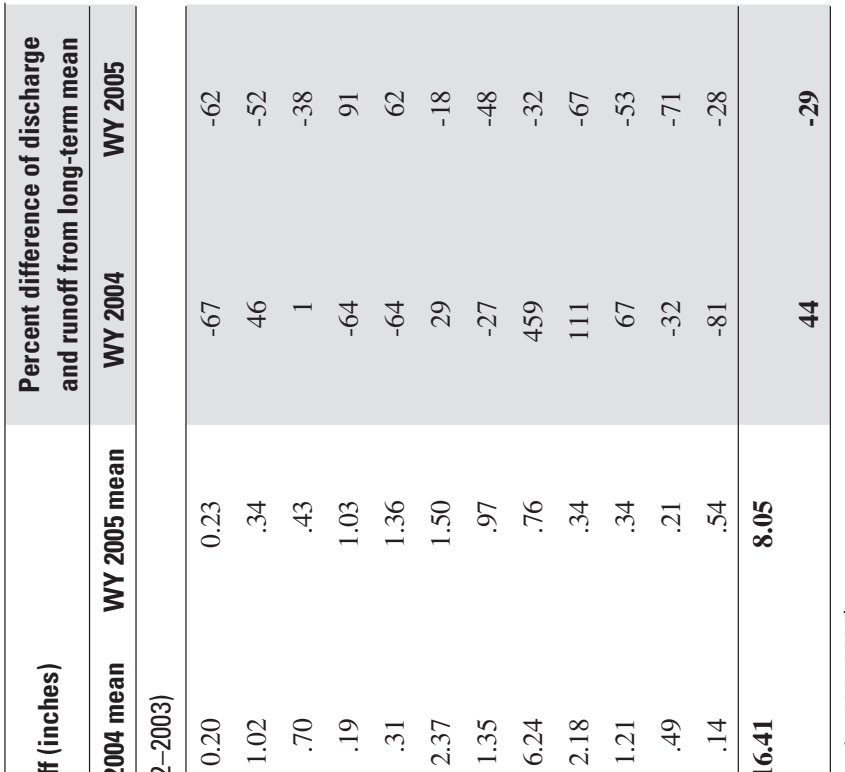

萬

峁 峁

들

응

$\stackrel{0}{2} \frac{0}{0}$

过

홍

응 응

号

드음

$\stackrel{\Phi}{ \pm}$

结 홍

ฮั

ब힌

돈

플

음

흔

嵌 응

恶

乐

롱

딘

్ㅗㅇ

는 든

告

至

言 峁

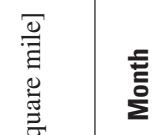

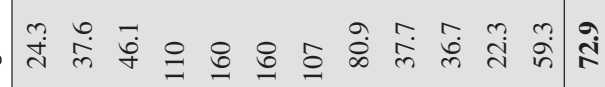

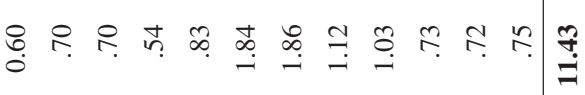

(

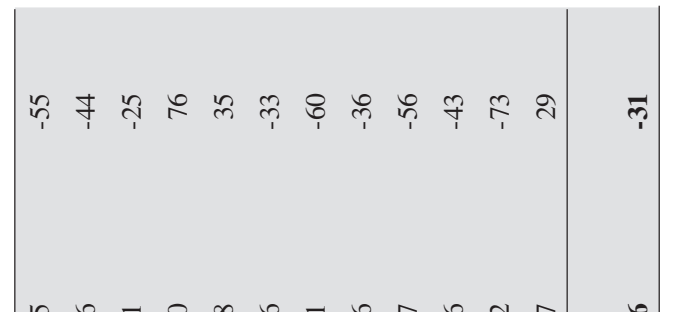

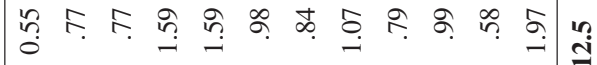

영

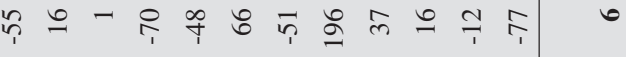
咅

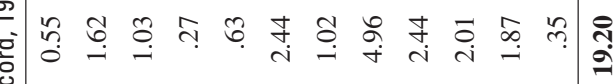

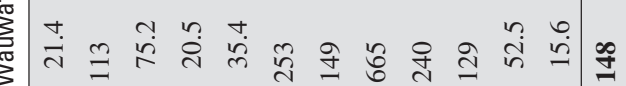

范

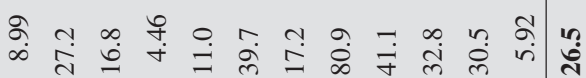

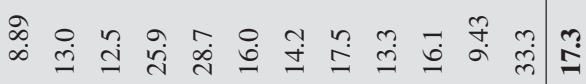

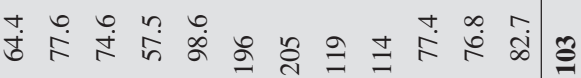

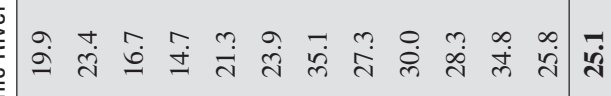

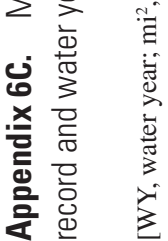

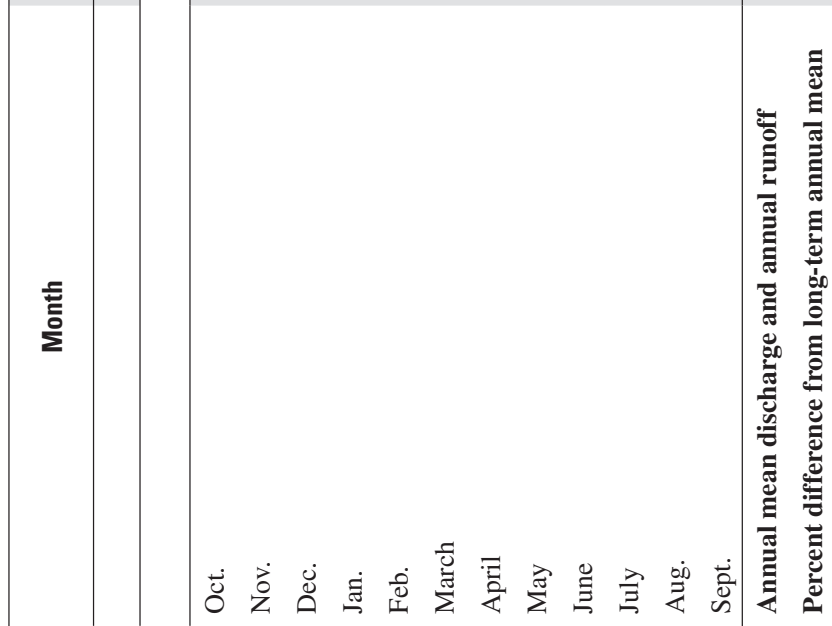

至

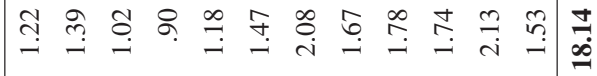

(n)
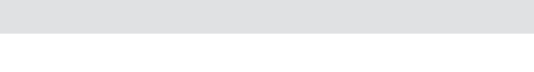
竞

$\stackrel{\mathscr{\Phi}}{ \pm}$

है

ब

듬 듬

듬

힘ำ

总 옹

艺

능

닌

든

잉 용

든 은

需

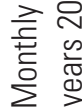

ن

즐

흥 음

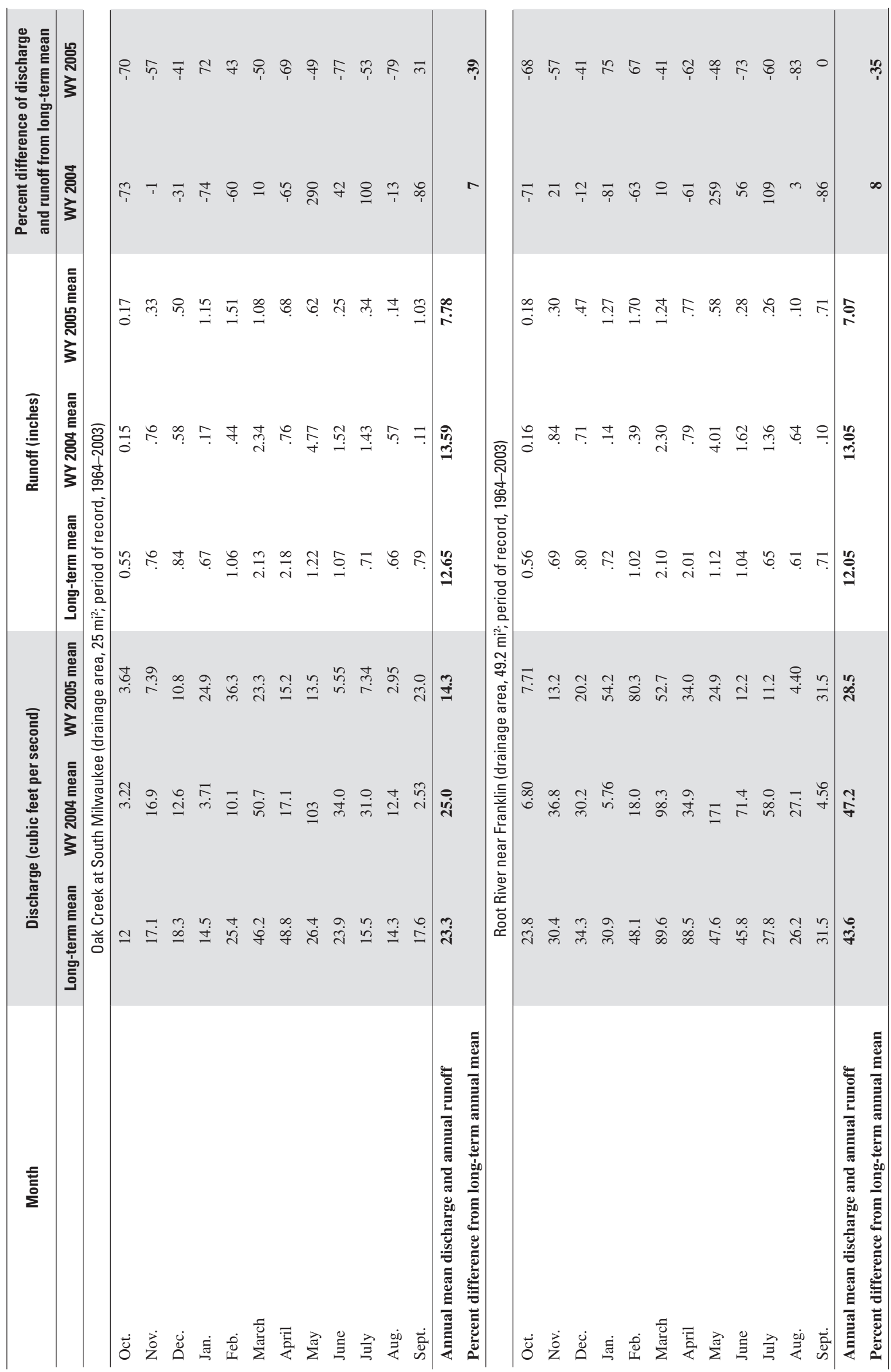


8 Printed on recycled paper 